
UNIVERSIDADE DE BRASÍLIA

FACULDADE DE TECNOLOGIA

DEPARTAMENTO DE ENGENHARIA CIVIL E AMBIENTAL

\title{
O COMPORTAMENTO DOS PEDESTRES DURANTE A TRA VESSIA DE VIAS EM FAIXAS NÃO SEMAFORIZADAS
}

\author{
PATRÍCIA VILELA MARGON
}

ORIENTADOR: PASTOR WILLY GONZALES TACO

TESE DE DOUTORADO EM TRANSPORTES

PUBLICAÇÃO T. TD - 005/2016

BRASÍLIA/DF: AGOSTO, 2016 


\section{UNIVERSIDADE DE BRASÍLIA \\ FACULDADE DE TECNOLOGIA \\ DEPARTAMENTO DE ENGENHARIA CIVIL E AMBIENTAL}

\section{O COMPORTAMENTO DOS PEDESTRES DURANTE A TRAVESSIA DE VIAS EM FAIXAS NÃO SEMAFORIZADAS}

\section{PATRÍCIA VILELA MARGON}

TESE SUBMETIDA AO DEPARTAMENTO DE ENGENHARIA CIVIL E AMBIENTAL DA FACULDADE DE TECNOLOGIA DA UNIVERSIDADE DE BRASÍLIA COMO PARTE DOS REQUISITOS NECESSÁRIOS PARA A OBTENÇÃO DO GRAU DE DOUTOR EM TRANSPORTES.

APROVADA POR:

Prof. Pastor Willy Gonzales Taco, Dr.

(Orientador)

Prof. Paulo César Marques da Silva, PhD.

(Examinador Interno)

Prof. ${ }^{a}$ Fabiana Serra de Arruda, Dr. ${ }^{\text {a }}$

(Examinadora Interna)

Prof. ${ }^{\text {a }}$ Ingrid Luiza Neto, Dr. ${ }^{\text {a }}$

(Examinadora Externa)

Prof. ${ }^{\text {a }}$ Érika Cristine Kneib, Dr. ${ }^{a}$

(Examinadora Externa)

Brasília/DF, 22 de agosto de 2016. 


\section{FICHA CATALOGRÁFICA}

MARGON, PATRICIA V.

O comportamento dos pedestres durante a travessia de vias em faixas não semaforizadas. [Brasília, Distrito Federal]2016.

xv, 200p, 210 x 297 mm (ENC/FT/UnB, Doutor, Transportes, 2016).

Tese de Doutorado - Universidade de Brasília. Faculdade de Tecnologia.

Departamento de Engenharia Civil e Ambiental.

1 - Estudo do comportamento do pedestre

2 - Travessias em faixas não semaforizadas

I - ENC/FT/UnB

II - Título (série)

\section{REFERÊNCIA BIBLIOGRÁFICA}

MARGON, PATRICIA V. (2016). O comportamento dos pedestres durante a travessia de vias em faixas não semaforizadas. Tese de Doutorado. Publicação T.D - 005/2016, Departamento de Engenharia Civil e Ambiental, Faculdade de Tecnologia, Universidade de Brasília, DF, 200p.

\section{CESSÃO DE DIREITOS}

AUTOR: Patrícia Vilela Margon

TÍTULO DA TESE: O comportamento dos pedestres durante a travessia de vias em faixas não semaforizadas.

GRAU: Doutor

ANO: 2016

É concedida à Universidade de Brasília permissão para reproduzir cópias desta tese de doutorado e para emprestar ou vender tais cópias somente para propósitos acadêmicos e científicos. A autora reserva outros direitos de publicação e nenhuma parte desta tese de doutorado pode ser reproduzida sem a autorização por escrito da autora.

Patrícia Vilela Margon

(62) 999712866 / (62) 3532-7357

Rua A30, Quadra 17A, Lote 12, Jardins Atenas

CEP: 74.885-578 - Goiânia/GO - Brasil 


\section{DEDICATÓRIA}

Ao meu amor, Rafael simplesmente por existir e dividir a sua existência comigo.

Aos meus filhos, Pedro e Hugo, grandes amores, por me apresentarem um mundo com outra dimensão. 


\section{AGRADECIMENTOS}

À minha fé, que pela certeza da existência de uma força maior, me guiou para percorrer esse caminho de conhecimento.

À minha família por me dar amor, apoio, compreensão e suporte durante todo o percurso: meus pais Júlio e Zilda, meus sogros Beto e Celinha que, como excelentes avós que são, supriram com muito afeto as minhas ausências, cuidando dos meus filhos e de mim.

Ao meu prezado orientador que, como o Pastor que é, me aceitou em seu rebanho e com seu jeito sereno, me guiou por caminhos difíceis, conquistando a minha amizade e admiração.

Ao meu querido amigo Eduardo Verano que, com o saber do seu não saber, apresentou a mim o que está em mim. Sou muito grata por você estar aqui.

Ao Instituto Federal de Goiás e ao Programa Pro-doutoral da CAPES, por permitir e financiar a minha capacitação.

Ao Professor Paulo César, pelas conversas desde a fase inicial do doutorado, com valiosas contribuições emolduradas em poucas palavras - como só os grandes mestres conseguem fazer.

Aos Professores Pastor, Paulo César, Fabiana, Ingrid e Erika que com paciência, leram, corrigiram e aconselharam a melhor forma de apresentação deste trabalho.

À Professora Yaeko, que me abriu as portas da sua sala e do seu conhecimento, me ajudando e estimulando a alcançar os meus objetivos.

Aos Professores Abimael, Evaldo, Fabiana, Fernando, Michelle, Pastor, Paulo César e Sérgio, que permitiram a aplicação do questionário aos alunos de suas turmas durante as aulas.

Aos amigos Sandro e Vinicius, pelo auxílio das filmagens das travessias de pedestres no Plano Piloto e pelas discussões sobre o tema. Aos alunos da disciplina Planejamento de Transportes 
do curso de Engenharia Civil, pela participação na coleta de dados e filmagens das pesquisas observacionais no Campus Darcy Ribeiro.

Aos Professores e Professoras do PPGT, por garantirem a transmissão do conhecimento, através das suas disciplinas, com respeito e gentileza.

Às secretárias Lucinete e Camila do PPGT, e Janaína do CEFTRU, pela presteza e competência.

Aos componentes do grupo de pesquisa "Comportamento em Transportes e Novas Tecnologias” por todas as conversas e debates a respeito do tema.

A todos os alunos, colegas queridos do PPGT, que fizeram parte desta minha jornada, nesses cinco anos de trajetória, cada um de vocês conquistou um cantinho de muito carinho nas minhas lembranças.

Aos meus amigos da Coordenação de Transportes do IFG Goiânia, que me apoiaram durante o afastamento para o doutorado: Lurdinha, Denise, Mariana, Beatriz, Luciana, Denis, Paulinho, Roberto, Ricardo e Marcos, é excelente trabalhar com vocês!

À minha enorme família da Felicidade e da Alegria, companheiros de sangue e de escolha que, com representantes de três gerações, sempre estiveram ao meu lado, brindando comigo nos momentos de descontração, com muitas risadas e leveza.

Aos queridos amigos do Pindura, que fizeram casa no meu coração e trouxeram música e poesia com seu EmCanto.

Aos amigos de Fazenda Freudiana que me acolheram e me aceitaram como companheira de jornada - uma nova está começando...

A todos vocês, muito obrigada! 


\section{RESUMO}

As travessias de pedestres representam o local onde ocorrem as principais interações entre veículos e pessoas. A faixa de travessia sinalizada é um espaço do pedestre por direito adquirido, garantido por lei, mas ainda desrespeitado por pedestres e motoristas. O presente estudo propõe um método que investigue o comportamento dos pedestres em relação à travessia na faixa não semaforizada. Para tal, são testadas duas hipóteses: (i) os pedestres podem ser categorizados por grupos de comportamentos semelhantes, que identificam perfis de comportamentos em relação à travessia na faixa; e (ii) fatores de comportamento individual, histórico de utilização da faixa, hábito de se deslocar a pé e fatores do ambiente de travessia exercem influência no comportamento dos pedestres ao utilizar a faixa não semaforizada.

O objetivo geral da pesquisa é desenvolver um método que auxilie planejadores de transporte e gestores de trânsito a compreender e identificar o perfil do pedestre de uma localidade a partir do seu comportamento durante a travessia na faixa, considerando variáveis individuais e ambientais, utilizando como suporte as teorias de análise do comportamento. $\mathrm{O}$ desenvolvimento de um modelo conceitual de travessia, possibilitou a organização dos critérios de observação dos movimentos dos pedestres focando três comportamentos: a aproximação da faixa, a velocidade de travessia e o foco de atenção durante a travessia.

A partir do modelo conceitual foi elaborado um questionário, composto por seis instrumentos de pesquisa diferentes: (i) identificação do perfil do pedestre; (ii) comportamento do pedestre em relação a faixa; (iii) histórico de utilização da faixa; (iv) ambiente de travessia; (v) hábitos de transporte e (vi) caraterísticas individuais. Os resultados do método, testado no Campus Darcy Ribeiro da Universidade de Brasília, passaram por análise fatorial (exploratória e confirmatória) e mostraram que o comportamento do pedestre pode ser caracterizado por três fatores latentes: “travessia favorável”, "hábito de caminhar” e "travessia desfavorável”, compostos por indicadores dos instrumentos de pesquisa.

Palavras-chave: pedestres, faixa de travessia não semaforizada, comportamento do pedestre. 


\begin{abstract}
The most significant interaction between a pedestrian and a vehicle occurs when the pedestrian crosses the road. The marked crosswalk is exclusively place for pedestrians, a right now protected by law, but yet often disrespected by both pedestrians and drivers. The present study proposes a method to investigate pedestrians' behavior on marked crosswalks (zebra crossings) where there are no traffic lights. To this end, two hypotheses have been tested: (i) pedestrians can be classified into groups of similar behavior, which identify profiles of similar behavior on zebra crossings; and (ii) individual behavioral factors, history of the use of crosswalks, the habit of walking to places and environmental factors influence the behavior of pedestrians on marked crosswalks that are far from traffic lights.
\end{abstract}

The overall objective of this study is to develop a method that helps transportation planners and traffic managers to understand and identify the pedestrian’s profile regarding a certain location according to their behavior while crossing the track, also considering individual and environmental variables, using as support behavior analysis theories. The development of a conceptual model of crossing enabled the observation criteria of the pedestrians' movements to be organized, focusing on three kinds of behavior: approach to the track, traversing speed and the focus of their attention during the crossing.

A questionnaire was developed from the conceptual model consisting of six different research criteria: (i) identification of the pedestrian's profile; (ii) the pedestrian's behavior concerning the crosswalk; (iii) history of use of the crosswalk; (iv) the crosswalk environment; (v) transportation habits and (vi) individual characteristics. The results of the method, tested at the Campus Darcy Ribeiro University of Brasilia, passed through factor analysis (exploratory and confirmatory) and showed that pedestrian behavior can be characterized by three latent factors: "favorable crossing", "habit of walking" and "unfavorable crossing", based on indicators of the research instruments.

Keywords: pedestrians, marked crosswalk, pedestrians’ behavior. 


\section{ÍNDICE}

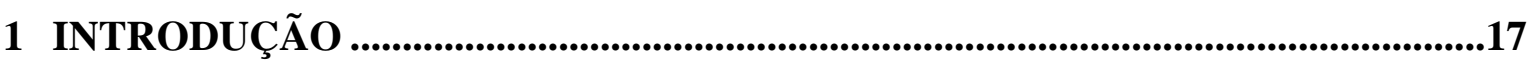

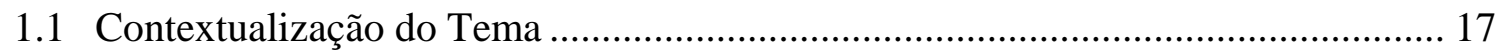

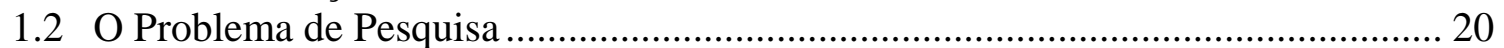



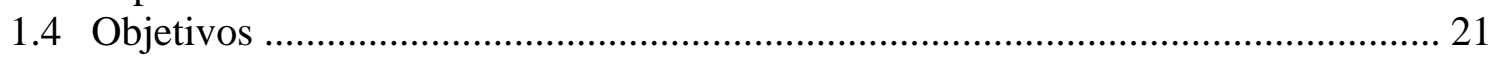

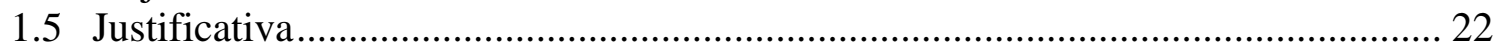

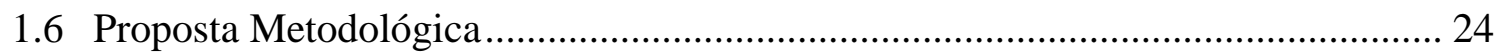

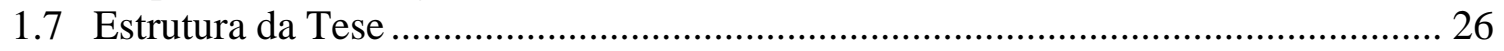

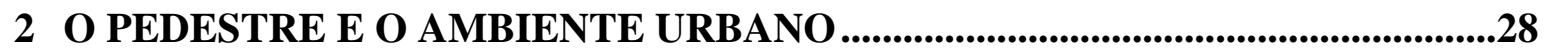

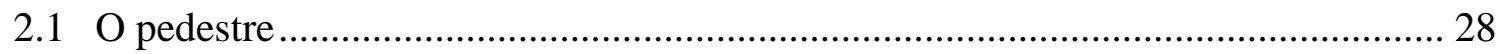

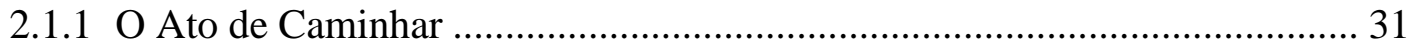

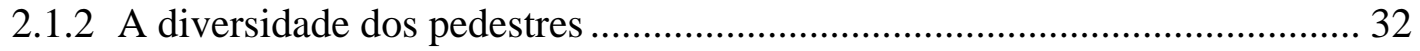

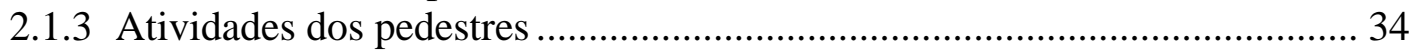

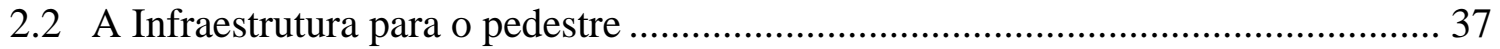

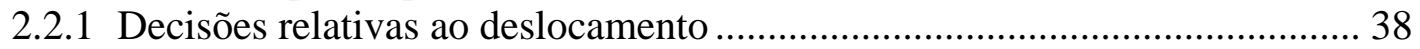

2.2.2 As instalações para os pedestres............................................................... 40

2.2.3 A qualidade dos espaços para pedestres.................................................... 43

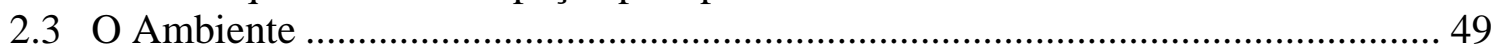

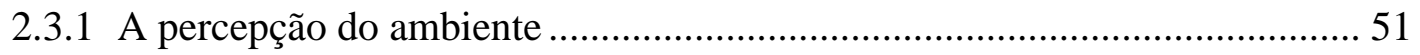

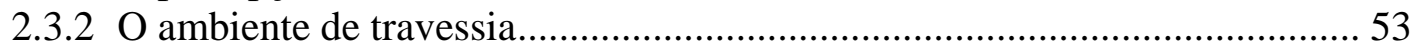

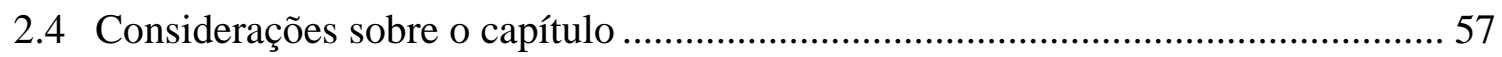

3 TEORIAS DE ANÁLISE DO COMPORTAMENTO .............................................58

3.1 Interação entre Pedestres, Motoristas e o Ambiente ............................................... 58

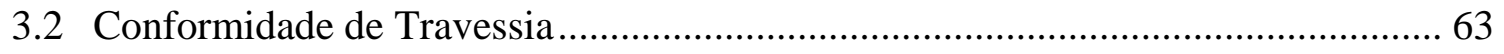

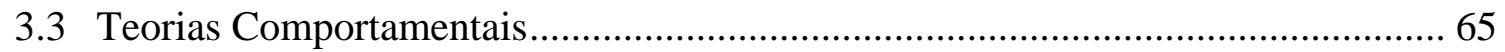

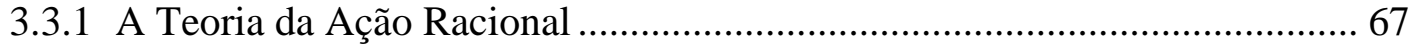

3.3.2 Teoria do Comportamento Planejado - TCP …........................................... 69

3.3.3 Comportamento Habitual ........................................................................... 73

3.4 Modelos Comportamentais Aplicados a Pedestres................................................... 73



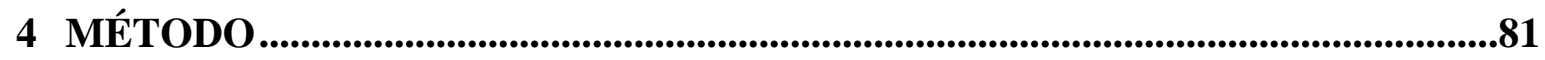

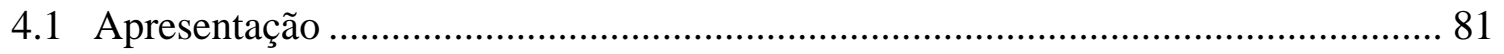

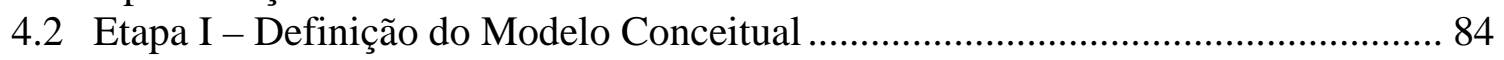

4.2.1 Conformidade de travessia em faixas não semaforizadas ............................. 84

4.2.2 Definição do Modelo Conceitual ............................................................ 91

4.3 Etapa 2: Levantamento das Crenças Salientes ....................................................... 96

4.4 Etapa 3: Levantamento das Variáveis de Interesse ................................................. 99

4.4.1 Parte I - Identificação do perfil do pedestre ............................................... 99

4.4.2 Parte II - Comportamento em relação a travessia na faixa .......................... 107

4.4.3 Parte III - Histórico de utilização da faixa.................................................. 109

4.4.4 Parte IV - Ambiente de travessia .............................................................. 110 
4.4.5 Parte V - Hábitos de Transporte ............................................................ 111

4.4.6 Parte VI - Características Individuais ....................................................... 112

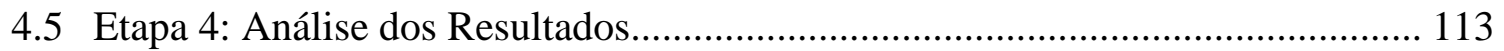

4.5.1 Modelagem por equações estruturais .................................................... 113

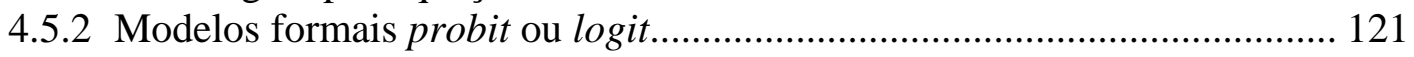

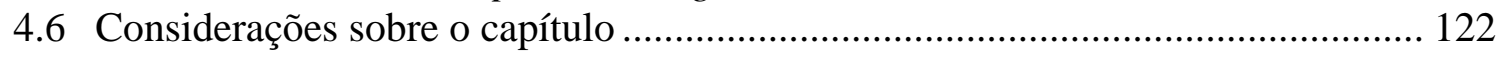

5 APLICAÇÃO DO MÉTODO E ANÁLISE DE RESULTADOS .........................124

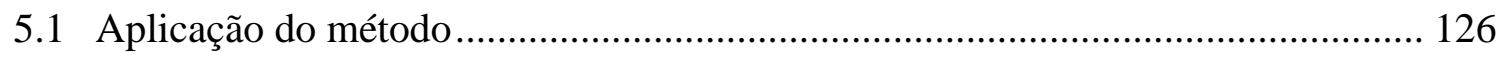

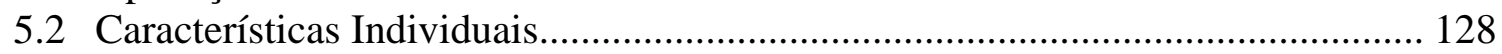

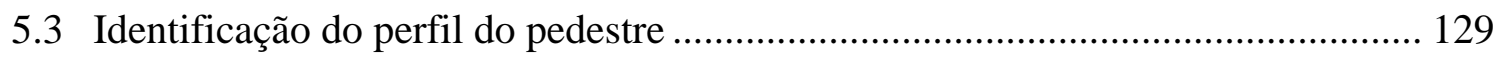

5.3.1 Análise da conformidade espacial........................................................... 129

5.3.2 Análise da conformidade temporal ............................................................. 132

5.3.3 Análise da conformidade com o sistema de trânsito .................................. 134

5.3.4 Indicação do perfil predominante .............................................................. 136

5.4 Faixas de travessia mais utilizadas no Campus Darcy Ribeiro .............................. 138

5.5 Fatores que influenciam o comportamento durante a travessia na faixa............... 139

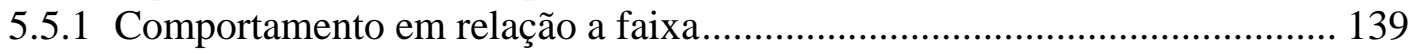

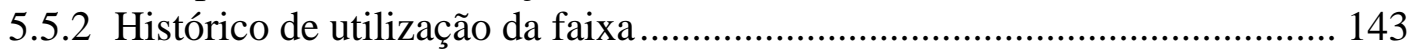

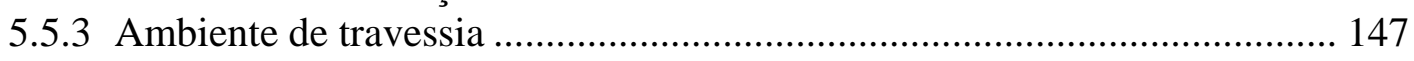

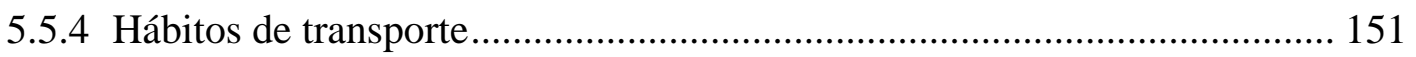

5.5.5 Fatores gerais que influenciam o comportamento durante a travessia........ 154

5.6 “Sinal de Vida”: Modelagem estatística - Método Probit ....................................... 160

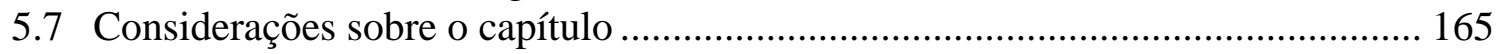

6 CONCLUSÕES E RECOMENDAÇÕES ................................................................167

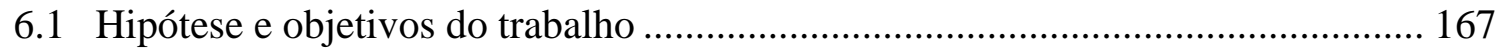

6.2 Limitações e recomendações para trabalhos futuros .......................................... 170

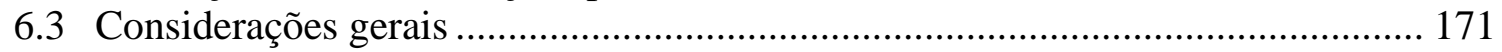

REFERÊNCIAS BIBLIOGRÁFICAS .................................................................173

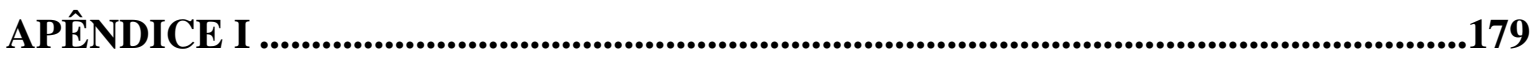

APÊNDICE II ........................................................................................................181

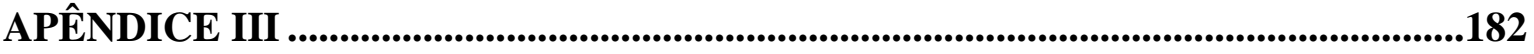

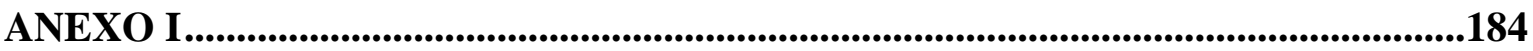




\section{LISTA DE TABELAS}

Tabela 3.1 - Revisão das pesquisas sobre comportamento de pedestres em travessias que

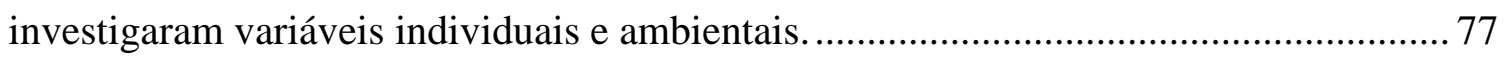

Tabela 4.1 - Crenças Salientes reveladas na Etapa 2 de elaboração do MIPP. ....................... 98

Tabela 4.2 - Itens de avaliação do comportamento de pedestres e motoristas. ...................... 101

Tabela 4.3 - Resumo das pesquisas observacionais utilizadas para compor as questões propostas para a identificação do perfil do pedestre. .................................................. 106

Tabela 4.4 - Regras gerais de dimensionamento de amostra mínima para a análise fatorial.

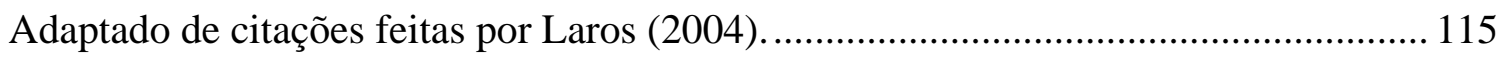

Tabela 4.5 - Índices de ajuste para adequação do modelo em AFC e MEE........................... 120

Tabela 5.1 - Aplicação do modelo conceitual de conformidade para indicação do perfil do

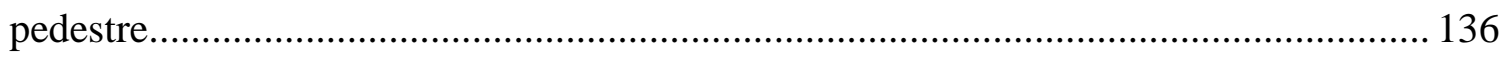

Tabela 5.2 - KMO e Teste de Esfericidade de Bartlett - Comportamento em relação a faixa.

Tabela 5.3 - Matriz de componente rotativa ${ }^{a}$ dos indicadores do comportamento em relação à faixa.

Tabela 5.4 - Matriz de covariância residual das oito variáveis. 142

Tabela 5.5 - Valores do Teste de Alfa de Cronbach para os construtos do comportamento em relação a faixa. 143

Tabela 5.6 - KMO e Teste de Esfericidade de Bartlett - Histórico de utilização faixa. 143

Tabela 5.7 - Matriz de componente rotativa ${ }^{a}$ dos indicadores do histórico de travessia na faixa.

Tabela 5.8 - Matriz de covariância residual das sete variáveis.

Tabela 5.9 - Valores do Teste de Alfa de Cronbach para os construtos do histórico de utilização da faixa

Tabela 5.10 - KMO e Teste de Esfericidade de Bartlett - Ambiente de travessia.

Tabela 5.11 - Matriz de componente rotativa ${ }^{a}$ dos indicadores do ambiente de travessia. ... 148

Tabela 5.12 - Matriz de covariância residual das treze variáveis.

Tabela 5.13 - Valores do Teste de Alfa de Cronbach para os construtos do ambiente de travessia.

Tabela 5.14 - KMO e Teste de Esfericidade de Bartlett - hábitos de transporte. 152

Tabela 5.15 - Matriz de componente rotativa ${ }^{a}$ dos indicadores de hábitos de transporte. 
Tabela 5.16 - Matriz de covariância residual das sete variáveis.

Tabela 5.17 - Valores do Teste de Alfa de Cronbach para os construtos dos hábitos de transporte.

Tabela 5.18- KMO e Teste de Esfericidade de Bartlett - fatores gerais. .............................. 155

Tabela 5.19 - Matriz de componente rotativa ${ }^{a}$ dos indicadores dos fatores gerais................. 157

Tabela 5.20 - Matriz de covariância residual das vinte e três variáveis. ................................ 159

Tabela 5.21 - Valores do Teste de Alfa de Cronbach para os construtos dos fatores gerais. 160

Tabela 5.22 - Resultados do Modelo Probit para Pedestres que atravessam na faixa. 163 


\section{LISTA DE FIGURAS}

Figura 1.1 - Estrutura esquemática da apresentação da tese................................................ 27

Figura 2.1 - Ilustração esquemática da variedade de pedestres............................................ 30

Figura 2.2 - Atividades desempenhadas pelos pedestres.................................................... 35

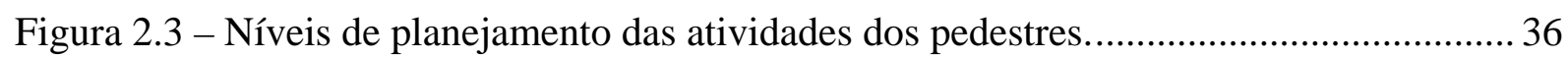

Figura 2.4 - Requisitos de espaço para pedestres. .............................................................. 43

Figura 2.5 - Ponderação dos indicadores de qualidade das calçadas..................................... 45

Figura 2.6 - Um dos 11 perfis utilizados na pesquisa de Muraleetharan et al. (2004)........... 47

Figura 2.7 - Formulário da pesquisa de campo feita por Carvalho (2006)............................. 48

Figura 2.8 - Proposta de Modelo do Processo de Determinação do Comportamento do

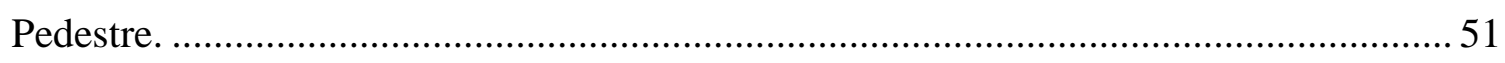

Figura 2.9 - Comportamentos observados para pedestres em momento de travessia. ............ 57

Figura 3.1- Fatores viário-ambientais que influenciam o comportamento do pedestre. ......... 59

Figura 3.2 - Teoria Geral dos Sistemas aplicada ao comportamento no trânsito. .................... 60

Figura 3.3 - Questões relacionadas ao comportamento e valores dos motoristas. ................... 61

Figura 3.4 - Valores que interferem e influenciam no comportamento dos motoristas. ......... 61

Figura 3.5 - A abordagem sistêmica de segurança. .............................................................. 62

Figura 3.6 - Teoria da Ação Racional. Fonte: Adaptado de Ajzen (1985).............................. 68

Figura 3.7 - Modificação da Teoria da Ação Racional para a Teoria do Comportamento

Planejado. Fonte: Adaptado de Ajzen (1991)................................................................ 70

Figura 3.8 - Fatores que influenciam o Comportamento Planejado...................................... 71

Figura 4.1 - Estrutura do método para identificar o comportamento do pedestre durante a travessia em faixas sinalizadas e não semaforizadas.

Figura 4.2 - Proposta de uma nova abordagem sistêmica de segurança tendo o conhecimento

do comportamento como entrada do sistema.

Figura 4.3 - Modelo conceitual do comportamento dos pedestres em momento de travessia.93

Figura 4.4 - Modelo Conceitual ajustado ao modelo da Teoria do Comportamento Planejado

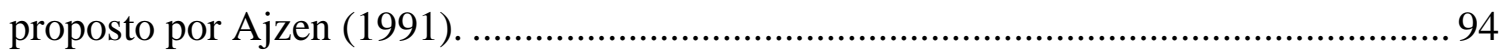

Figura 4.5 - Modelo conceitual de conformidade de travessia em faixas não semaforizadas. 95

Figura 4.6 - Localização dos três pontos de pesquisa em faixas ao longo da via L3. ........... 102

Figura 4.7 - Comportamento observado dos pedestres em relação à faixa de pedestres. Fonte:

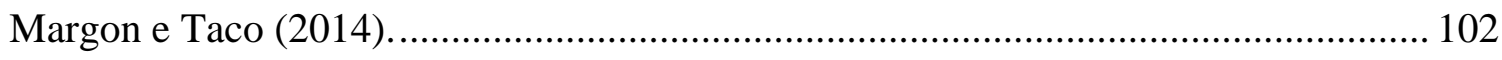


Figura 4.8 - Comportamento observado dos motoristas em relação à faixa de pedestres.

Fonte: Margon e Taco (2014).

Figura 4.9 - Localização dos pontos de pesquisa: faixa entre os blocos PJC e ICC Norte

(Faixa 1) e via L3 Norte - Faculdade de Tecnologia (Faixa 2)

Figura 5.1 - Campus Darcy Ribeiro com a indicação numerada das faixas de pedestre não semaforizadas e de alguns pontos referenciais.

Figura 5.2 - Proporção de pedestres, atravessando sozinho, em relação a conformidade espacial.

Figura 5.3 - Proporção de pedestres, atravessando com um grupo de pessoas desconhecidas, em relação a conformidade espacial.

Figura 5.4 - Proporção de pedestres, atravessando acompanhado de alguém conhecido, em relação a conformidade espacial.

Figura 5.5 - Proporção das pessoas escolhidas pelos respondentes ao se imaginar atravessando com alguém que considere importante.

Figura 5.6 - Proporção de pedestres, atravessando sozinho, em relação a conformidade temporal.

Figura 5.7 - Proporção de pedestres, atravessando com um grupo de pessoas desconhecidas, em relação a conformidade temporal.

Figura 5.8 - Proporção de pedestres, atravessando acompanhado de alguém conhecido, em relação a conformidade temporal.

Figura 5.9 - Proporção de pedestres, atravessando sozinho, em relação a conformidade com o sistema de trânsito.

Figura 5.10 - Proporção de pedestres, atravessando com um grupo de pessoas desconhecidas, em relação a conformidade com o sistema de trânsito.

Figura 5.11 - Proporção de pedestres, atravessando acompanhado de alguém conhecido, em relação a conformidade com o sistema de trânsito.

Figura 5.12 - Caracterização do perfil dos pedestres da UnB que responderam ao questionário.

Figura 5.13 - Proporção das faixas mais utilizadas no Campus Darcy Ribeiro.

Figura 5.14 - Scree plot dos autovalores dos indicadores do comportamento em relação a faixa.

Figura 5.15 - Modelo da análise fatorial confirmatória e índice de ajustes do modelo. 
Figura 5.16 - Scree plot dos autovalores dos indicadores do histórico de utilização da faixa

Figura 5.17 - Modelo da análise fatorial confirmatória e índice de ajustes do modelo.......... 146

Figura 5.18 - Scree plot dos autovalores dos indicadores do comportamento em relação a

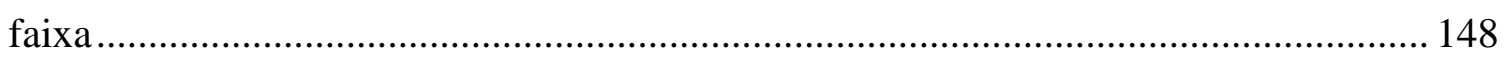

Figura 5.19 - Modelo da análise fatorial confirmatória e índice de ajustes do modelo.......... 149

Figura 5.20 - Proporção do meio de transporte rotineiro utilizado pelos respondentes........ 151

Figura 5.21 - Frequência em que utiliza a caminhada para desempenhar atividades............. 151

Figura 5.22 - Scree plot dos autovalores dos indicadores do comportamento em relação a faixa 152

Figura 5.23 - Modelo da análise fatorial confirmatória e índices de ajustes do modelo ........ 153

Figura 5.24 - Scree plot dos autovalores dos indicadores dos fatores gerais. ........................ 156

Figura 5.25 - Modelo da análise fatorial confirmatória e índice de ajustes do modelo.......... 158 


\section{LISTA DE SIGLAS}

AFC - Análise fatorial confirmatória

AFE - Análise fatorial exploratória

CLSW - Comércio Local Sudoeste, localidade da cidade de Brasília

CNT - Código Nacional de Trânsito

CTB - Código de Trânsito Brasileiro

HCM - Highway Capacity Manual

KMO - critério ou índice de Kaiser-Meyer-Olkin

MEE - Modelagem por Equações Estruturais

MIPP - Método de Indicação do Perfil do Pedestre

SPSS - Statistical Package for the Social Sciences software de análises estatísticas IBM

TAR - Teoria da Ação Racional

TCP - Teoria do Comportamento Planejado 


\section{INTRODUÇÃO}

Ao observar os deslocamentos nas grandes cidades pode-se perceber que o direito de ir e vir das pessoas, quando caminham, vem sendo continuamente restringido, em tempo e espaço, para favorecer outros atores do sistema de circulação e do ambiente urbano. Investigar o comportamento das pessoas enquanto estas se deslocam andando pode esclarecer pontos fundamentais para a conformação do ambiente urbano às necessidades das pessoas que o habitam e por ele circulam. É necessário ter o conhecimento de que projetar um sistema de circulação para pessoas não significa, apenas, planejar esquemas que proporcionem uma caminhada segura. A qualidade do caminhar, em termos de dispêndio de energia e acesso ao uso das facilidades e equipamentos urbanos, também deve ser considerada.

O deslocamento a pé deve ser visto, não só como uma questão de segurança de tráfego, mas também como uma questão de bem-estar, saúde e qualidade de vida. Implantar sistemas de circulação que sejam amistosos para as pessoas é o grande desafio das cidades, pois caminhar livre e seguramente deve ser encarado como um direito humano básico. Este capítulo inicial busca contextualizar o tema abordado na tese, descrever o problema de pesquisa, as hipóteses de trabalho e os objetivos propostos. A importância da realização deste estudo está pautada na sua justificativa e na delimitação da investigação relatadas a seguir juntamente com a proposta para a estruturação do texto.

\subsection{CONTEXTUALIZAÇÃo do TEMA}

A contextualização do tema deste estudo só irá atingir o seu objetivo com a inclusão do leitor no contexto das suas atitudes, como sujeito ativo no ato de se deslocar a pé, em qualquer momento do dia ou semana, em qualquer trajeto curto ou longo, durante a sua rotina. Desta forma, peço permissão a você leitor para, somente neste momento de contextualização, me distanciar um pouco das regras que regem as publicações acadêmicas e tornar esse início de leitura um pouco mais íntimo pois, para esclarecer a abordagem sobre o pedestre que esse estudo pretende, é necessário que caminhemos juntos. Assim, é fundamental que você responda, para você mesmo, você é um pedestre? 
Provavelmente, após pensar por alguns segundos, você respondeu que sim, afinal em alguma hora do desenvolvimento da sua rotina você deve caminhar em alguma rua ou estacionamento, mesmo que para completar um pequeno trecho da sua viagem realizada por outro modo de transporte. Mas, ainda dentro desse contexto, é preciso perguntar o que é o pedestre? A conceituação de pedestre, apresentada em manuais de trânsito e planos diretores em nível mundial, sempre remete às pessoas que fazem parte do sistema de transporte e circulação de uma cidade com a característica de se deslocarem andando, livremente ou com auxílio de equipamentos, nos casos de restrições da capacidade de andar. Certo, mas se deslocar andando é uma característica inerente aos seres humanos. Quando nos tornamos pedestres então?

O pedestre começou a existir quando o sistema de circulação e transporte das cidades começou a ser planejado, com a necessidade de organizar o deslocamento dos veículos. Assim como os veículos, as pessoas começaram a ser vistas pelos planos de transporte urbano sob o enfoque de características similares às características veiculares, como velocidade, direção de deslocamento, tempo de travessia em cruzamentos, entre outras, e deixamos de ser pessoas para nos tornar pedestres.

Ao longo do tempo, algumas pesquisas acadêmicas investigaram características individuais relacionadas ao comportamento no trânsito urbano, como a percepção e aceitação de riscos durante os deslocamentos, utilizando veículos ou não. Mas a questão motivadora desse estudo é, justamente, se os planejadores de transporte urbano não estão sendo reducionistas ao considerar como pedestre, no sistema de circulação e transporte, uma pessoa limitada às características físicas de seu deslocamento e, em uma abordagem ainda pouco utilizada, à percepção dos riscos que esse ato envolve.

Criar um ambiente favorável ao deslocamento das pessoas exige mais do que instalar facilidades para travessias ou estabelecer a largura de uma calçada. Um sistema de circulação planejado para pessoas exige uma visão geral, tanto da dinâmica dos deslocamentos quanto dos menores detalhes, que envolvem desde o planejamento urbano e da circulação até os tipos de materiais que são utilizados para o calçamento. As instalações deste sistema devem ser acessíveis a todas as pessoas, incluindo crianças, idosos e pessoas com deficiência, e precisam ser planejadas, projetadas, operadas e mantidas de modo que possam ser utilizadas de maneira equitativa. Criar um ambiente favorável ao pedestre é criar um ambiente atrativo, para que as 
pessoas reconheçam a prioridade do seu espaço de deslocamento enquanto pedestres dentro do sistema de circulação, e façam uso desse espaço.

As interações entre os todos os usuários do sistema de circulação e transporte de uma cidade sejam eles pedestres, ciclistas ou condutores de veículos motorizados - são inevitáveis, pois se trata de um sistema compartilhado em sua função. Mas estas interações, quando não recebem a devida atenção, podem resultar em conflitos, decorrentes da disputa por tempo e espaço. Para o pedestre, especialmente, as interações com outros veículos podem interferir nas escolhas de rotas, ser responsáveis por atrasos nos deslocamentos, representar maior exposição ao risco de acidentes e, consequentemente, causar desconforto e insegurança. Os conflitos entre pessoas e veículos acontecem principalmente nos momentos de travessia de vias. Devido a esses fatos, essa pesquisa elege como foco de investigação a faixa de pedestre.

$\mathrm{Na}$ faixa de pedestre, o pedestre tem seu espaço de travessia garantido por lei, além da prioridade de cruzamento da via. Neste local, a interação entre pedestres e motoristas é influenciada por diversos fatores individuais e ambientas. Estes fatores exercem influência na forma em que o pedestre realiza a travessia, desde a abordagem do fluxo de veículos, até o término da travessia, resultando em uma sequência de comportamentos. O conhecimento destes comportamentos e dos fatores que os influenciam pode ser valoroso para os órgãos de planejamento da circulação e gestores de trânsito, pois permitiriam um melhor conhecimento das pessoas enquanto pedestres, permitindo a elaboração de medidas de controle mais adequadas às necessidades da população.

O estudo aqui descrito, teve a intenção de observar e caracterizar o comportamento do pedestre durante a travessia, utilizando a faixa de pedestre não semaforizada. A proposta fundamental do trabalho é iniciar uma discussão sobre o desenvolvimento de um método, que possa caracterizar perfis de comportamento dos pedestres, utilizando o momento da travessia como fenômeno de pesquisa. A ideia de elaborar e identificar um perfil de comportamento do pedestre pode auxiliar na indicação de parâmetros para características individuais e ambientais que contribuem com a formação desse perfil. 


\subsection{O Problema de Pesquisa}

As travessias de pedestres representam o local onde ocorrem as principais interações entre veículos e pedestres. De acordo com as interações mais comuns, as travessias de pedestres podem ocorrer em locais:

i) não sinalizados - locais onde não existe nenhum tipo de sinalização favorecendo a travessia, os pedestres analisam o fluxo de veículos, aproveitando os intervalos (brechas) entre as chegadas dos veículos que permitam a realização da travessia.

ii) semaforizados - locais em que existe uma sinalização semafórica, nos quais tanto os pedestres quanto os veículos possuem um tempo específico para suas travessias.

iii) sinalizados - locais em que há apenas a sinalização estatigráfica horizontal, demarcados por faixas de travessia de pedestre nas quais, segundo as leis de trânsito brasileiras, os veículos devem dar preferência aos pedestres.

Entretanto, em cada tipo de travessia, os pedestres e condutores de veículos apresentam comportamentos distintos, influenciados pelas características individuais, pelo volume do tráfego local, ambiente de travessia, iluminação existente e clima, por exemplo. A faixa de travessia sinalizada é um espaço do pedestre por direito adquirido, garantido por lei através do Código Nacional de Trânsito (CNT), desde 1966, mas mesmo assim é ainda desrespeitada por pedestres e motoristas. Para entender a diferença de comportamento das pessoas perante este espaço é necessária uma investigação sobre a forma de uso deste espaço por tais pessoas.

Algumas perguntas podem ser elaboradas a respeito da relação das pessoas com o espaço urbano quando esta é representada pela relação dos pedestres com o local de travessia: como o pedestre faz a aproximação da faixa antes de iniciar a travessia? Quais características individuais e do ambiente de travessia exercem influência nesse ato? Durante a travessia o pedestre se comporta de forma diferente de quando caminha na calçada? O trabalho resultante desta pesquisa é delimitado à pretensão de responder à seguinte pergunta: como o pedestre se comporta durante a travessia na faixa sinalizada não semaforizada, em relação ao uso do espaço de travessia?

A delimitação proposta pelo problema de pesquisa visa incluir no foco de estudo somente os pedestres que atravessam as vias utilizando a faixa de pedestres sinalizada e não semaforizada. A intenção é explorar, de forma investigativa, o comportamento das pessoas em um momento 
de interação direta com os veículos, em um local de conflitos, que pode gerar desconforto e insegurança para quem se desloca a pé. A escolha do local de travessia, definido pela faixa de pedestres não semaforizada, se deve ao fato deste ambiente representar o lugar onde ocorre uma forma exposta de interação entre pessoas e veículos no sistema de trânsito, através da negociação e da administração dos conflitos inerentes à utilização deste espaço por pedestres e motoristas.

É também interessante abordar o conhecimento comum de que a utilização correta da faixa de travessia envolve tanto o comportamento do motorista quanto o comportamento do pedestre, pois é preciso que os dois reconheçam e respeitem esse espaço. Para que a faixa de pedestres possa exercer a sua função de destinação, é necessário que todos os atuantes do sistema de trânsito saibam como proceder diante dela. Mas estudar o comportamento envolve prioritariamente a eleição de um comportamento específico a ser investigado, e aqui fica reafirmado que o interesse desse estudo está na compreensão do comportamento do pedestre durante a travessia na faixa não semaforizada, não abordando em nenhuma análise aprofundada o comportamento do motorista.

\subsection{Hipóteses de Trabalho}

O presente trabalho busca testar duas hipóteses:

(i) Os pedestres podem ser categorizados por categorias de comportamentos semelhantes, que caracterizam padrões de comportamentos em relação à travessia na faixa, através de critérios de avaliação da forma de aproximação e utilização do espaço de travessia.

(ii) Fatores de características individual, histórico de utilização da faixa, hábito de se deslocar a pé e fatores do ambiente de travessia exercem influência no comportamento dos pedestres ao utilizar a faixa não semaforizada.

\subsection{OвJETIVOS}

O objetivo geral da pesquisa é desenvolver um método que auxilie planejadores de transporte e gestores de trânsito a compreender e identificar o perfil do pedestre de uma localidade a partir 
do seu comportamento durante a travessia na faixa, considerando variáveis individuais e ambientais, utilizando como suporte as teorias de análise do comportamento.

Considerando que o comportamento alvo do estudo é a forma de utilização da faixa de pedestres não semaforizada, durante a travessia, tem-se os seguintes objetivos específicos:

i) Desenvolver um modelo conceitual de comportamento do pedestre durante a travessia em faixas não semaforizadas, para caracterizar o comportamento predominante dos pedestres. Esse modelo servirá como diretriz para elaborar um método de indicação do perfil do pedestre na região em que o método for aplicado.

ii) Testar o método elaborado no Campus Darcy Ribeiro da Universidade de Brasília, no Distrito Federal, para verificar em que grau as variáveis: i) comportamentais (atitude, normas sociais, percepção de controle e intenção); ii) do comportamento histórico em relação à faixa de pedestre; iii) do hábito de andar a pé e iv) as características individuais (sexo, idade, local de moradia, tempo de residência no local, escolaridade e empregabilidade), se relacionam com o perfil do pedestre determinado pelo modelo conceitual.

\subsection{JUSTIFICATIVA}

A disputa pelo espaço coloca os usuários do sistema de circulação e transporte de uma cidade em conflito permanente. No entanto o acesso às vias e aos meios de transporte é muito influenciado pelas diferenças sociais, políticas e econômicas entre as pessoas. Geralmente, existem três tipos de exclusão que mais preocupam aqueles que analisam a equidade na distribuição do espaço urbano: a exclusão econômica, a exclusão das pessoas que circulam a pé ou de bicicleta, e a exclusão das pessoas com limitações na sua mobilidade (VASCONCELLOS, 2000). Para que o compartilhamento do espaço ocorra de forma satisfatória, as normas regulatórias de travessia de vias por pedestres devem representar o comportamento humano da forma mais realista possível, unindo as necessidades de segurança e conforto, na tentativa de minimizar os riscos de acidentes e incentivar o respeito aos diversos componentes da circulação. 
As abordagens tradicionais nos estudos que investigam os deslocamentos dos pedestres consideram basicamente duas vertentes de investigação. Estudos relatados nos capítulos sequenciais (CARVALHO, 2006; FERREIRA e SANCHES, 2001; FRUIN, 1971; KHISTY, 1994; MURALEETHARAN et al., 2004) tentam compreender o comportamento dos pedestres através da análise de características de deslocamento, como velocidade e caminho de percurso, e do nível de serviço ofertado para o seu deslocamento. Geralmente as análises estão focadas em aspectos físicos das vias e travessias, e a influência destes fatores principalmente na segurança da travessia, nos atrasos de deslocamento e na escolha da rota.

Outras pesquisas focaram a análise do comportamento do pedestre relacionado ao risco assumido durante o deslocamento e à percepção deste (ARIOTTI, 2006; BARBOSA, 2010; CHOI e SAYYAR, 2012; KAPARIAS et al., 2012; SANT'ANNA, 2006). Dentro desta linha de risco assumido, Díaz (2002) utilizou a Teoria do Comportamento Planejado de Ajzen (1991) para investigar as intenções dos pedestres em violar as regras de trânsito. Mas, apesar dos bons resultados apresentados por esses estudos, ainda existe uma lacuna a ser preenchida pela investigação do comportamento do pedestre durante as travessias de vias.

Os estudos de comportamento dos pedestres citados no parágrafo anterior utilizaram instrumentos de pesquisa com a finalidade de investigar, como foi dito, a percepção e aceitação de riscos ao caminharem. $\mathrm{O}$ presente estudo propõe um método que investigue o comportamento dos pedestres em relação à travessia na faixa não semaforizada, avaliando desde a aproximação do espaço de travessia, representado pela faixa, até o foco de atenção e velocidade de caminhada durante a travessia. O conhecimento almejado pelo estudo tem a sua importância na compreensão das necessidades de segurança, conforto e bem-estar do pedestre durante a realização da travessia. Para tal, o método proposto, pretende investigar o comportamento dos pedestres, indicando um perfil de comportamento predominante.

A definição do perfil e o conhecimento das características a ele relacionadas podem auxiliar no planejamento da circulação, controle de acidentes e campanhas educativas, tornando-as mais eficazes. A pretensão do método é realizar uma identificação do pedestre, para que essas medidas sejam direcionadas para as características de um público alvo conhecido, definido pela aplicação do método em uma determinada região. O método também busca identificar quais os fatores que mais contribuem para uma melhor utilização da faixa não semaforizada, 
vislumbrando o perfil do pedestre que atravessa na faixa de forma assertiva e atenta e as possibilidades de estimular e reforçar esse comportamento. Grande parte das pesquisas que investigam o comportamento do pedestre se interessam em caracterizar comportamentos de risco vinculadas a características individuais. O que está sendo proposto por esse trabalho é um método de investigação que caracterize comportamentos de acerto, e não de risco, durante a travessia na faixa.

\subsection{Proposta Metodológica}

A pesquisa foi desenvolvida com fundamento nas teorias comportamentais que, de forma geral, preveem a investigação de um comportamento através de coleta de informações por pesquisas de opinião, geralmente pela resposta de questionários. O método desenvolvido neste trabalho é composto de quatro etapas: i) a elaboração de um modelo conceitual da travessia do pedestre em relação à conformidade de travessia; ii) levantamento das crenças salientes sobre o comportamento investigado através de um questionário aberto; iii) identificação do comportamento do pedestre através da aplicação de um questionário fechado; iv) análise estatística dos resultados.

A função do modelo conceitual, constituinte da primeira etapa do método, é representar, de forma simplificada, as principais características do fenômeno investigado. As travessias de pedestres são pontos críticos do planejamento da circulação e da mobilidade urbana, pois representam os locais mais sensíveis à segurança e conforto de quem se desloca a pé. $\mathrm{O}$ conhecimento das teorias baseadas em comportamento é necessário na construção conceitual do modelo, que auxiliou a elaboração de diretrizes de investigação do comportamento das pessoas durante a travessia na faixa de pedestres e, a partir destas diretrizes, foi composto o questionário fechado da pesquisa de opinião.

Rouphail (1984) sugere que o comportamento adotado pelos pedestres, no processo que envolve a tarefa de atravessar uma via, caracteriza a conformidade de travessia. A conformidade de travessia representa a adequação espacial e temporal no uso da estrutura de travessia pelos pedestres. A análise do comportamento de pedestres pode ser realizada a partir da categorização das diferentes classes de usuários em função de seus padrões de comportamento. Sisiopiku e Akin (2003) sugerem a classificação dos pedestres em relação à conformidade de travessia 
espacial. Liu et al. (2000), na descrição do modelo de simulação de movimentos de pedestres e veículos, classificam os pedestres de acordo com o conceito de conformidade de travessia temporal.

Como a proposta da primeira etapa é elaborar um modelo conceitual, que caracterize o comportamento dos pedestres durante a travessia em faixas sinalizadas, a conformidade espacial já é definida, e delimitada, pela amostra observada, pois somente serão relatados os comportamentos dos pedestres que realizam a travessia na área demarcada pela pintura horizontal de sinalização. A análise da conformidade temporal irá diferenciar aqui o comportamento dos pedestres, durante a travessia na faixa sinalizada. Além das conformidades espacial e temporal, o modelo conceitual propõe a investigação de uma conformidade com o sistema de trânsito. A conformidade com o sistema de trânsito procura avaliar se o pedestre se identifica como ator desse sistema, com consciência de seus direitos e deveres, para que a interação entre os atores desse sistema - pessoas e veículos - possa acontecer de forma segura e confortável.

As etapas do método seguiram o seguinte roteiro de atividades:

i) Definição de um modelo conceitual de travessia para classificar o perfil do pedestre, através de pesquisas de observação.

ii) Levantamento das crenças salientes, através da identificação de fatores comportamentais, referenciais normativos, e fatores de controle. Este levantamento de crenças salientes é feito individualmente, em um questionário com formato de resposta livre. Os resultados da segunda etapa auxiliaram a elaboração dos construtos do questionário fechado da próxima etapa da pesquisa.

iii) Levantamento das variáveis de investigação através da aplicação de um questionário de respostas objetivas, elaborado a partir da formulação de medidas diretas para identificação do perfil de comportamento do pedestre durante a travessia, dos construtos provenientes das teorias comportamentais, das características sócio culturais, e outros fatores que considerados pertinentes. 
iv) Avaliação da representatividade do modelo conceitual e das variáveis escolhidas. Análise estatística dos resultados, para o identificar perfil dominante dos pedestres na região de e,studo e o grau de relação desse perfil com as variáveis consideradas.

\subsection{ESTRUTURA DA TESE}

Para atingir os objetivos supracitados, além do capítulo introdutório, a tese contempla três fases (Figura 1.1), são elas:

i) Elaboração do referencial teórico, etapa apresentada nos capítulos 2 e 3 é composta pela revisão da literatura, em que é elaborada a base conceitual da tese e são identificados os elementos necessários para o desenvolvimento do modelo conceitual e dos procedimentos metodológicos.

ii) Procedimentos metodológicos, fase composta pelos capítulos 4 e 5, que respectivamente, descrevem a formulação do instrumento de pesquisa (questionário) e sua aplicação juntamente com a análise dos dados coletados, e

iii) Análises conclusivas, etapa final da composição do texto composta por um único capítulo (6), onde é verificado se objetivos do trabalho foram alcançados, e são relatadas as contribuições e limitações da pesquisa realizada, assim como as sugestões para trabalhos futuros. 


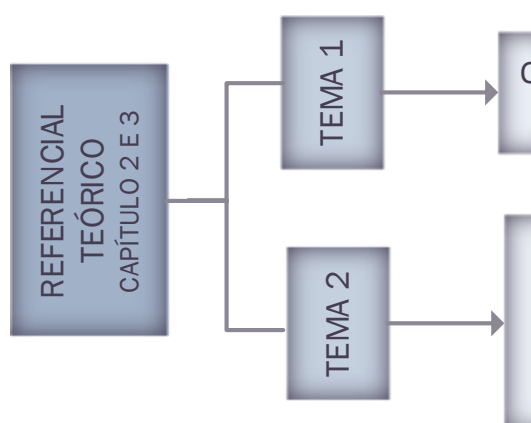

O PEDESTRE E O AMBIENTE URBANO

TEORIAS DE ANÁLISE DO COMPORTAMENTO MODELOS

COMPORTAMENTAIS

APLICADOS A PEDESTRES
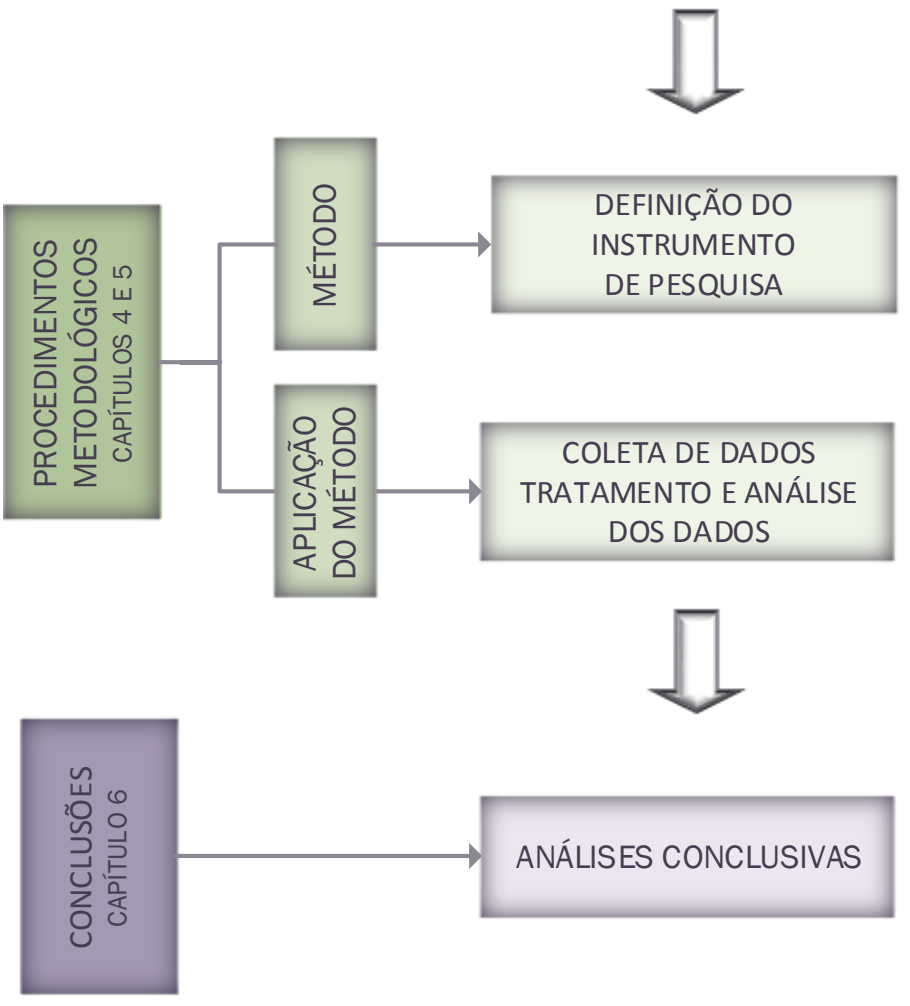

BASE CONCEITUAL E IDENTIFICAÇÃO DOS ELEMENTOS PARA O DESENVOLVIMENTO DO MODELO CONCEITUAL E DOS PROCEDIMENTOS METODOLÓGICOS

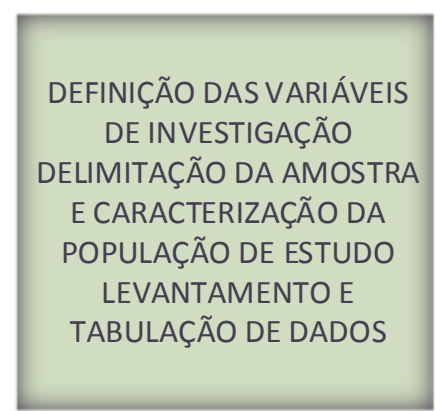

ANÁLISE DA VALIDADE DO MODELO E DAS VARIÁVEIS NA REPRESENTAÇÃO DO FENÔMENO INVESTIGADO, VERIFICAÇÃO DOS OBJETIVOS DA TESE, LIMITAÇÕES DA PESQUISA E RECOMENDAÇÕES PARA TRABALHOS FUTUROS

Figura 1.1 - Estrutura esquemática da apresentação da tese. 


\section{O PEDESTRE E O AMBIENTE URBANO}

Se a pouco menos de um século as leis dividiram a cidadania em pedestres e condutores, a orientação atual é deixar de ser pedestre no império do automóvel para ser cidadãos e cidadãs no império da razão urbana. Não é que a cidade deva ser para os pedestres, é que a cidadania se edifica a pé.

Sanz (2012)

O presente estudo busca uma caracterização do comportamento dos pedestres durante a travessia na faixa tratando-se, portanto, de um comportamento específico. Este capítulo intenciona levantar a discussão a respeito das características das pessoas que se deslocam a pé, primeiramente conceituando o termo "pedestre", com base em pesquisas, manuais e normas técnicas, brasileiros e internacionais.

Após a conceituação, é feita uma revisão a respeito do espaço físico necessário para os deslocamentos e da qualidade desse espaço, que compõe o ambiente urbano em que o pedestre circula. Para nortear a pesquisa é necessária também a identificação das variáveis comportamentais pertinentes ao indivíduo "pedestre", assim como os fatores que afetam diretamente esse comportamento presentes no ambiente de travessia.

As teorias de análise do comportamento e da psicologia ambiental, serão abordadas, na busca de identificar dentro das bases teóricas os procedimentos para análise do comportamento do pedestre no ambiente da travessia. $\mathrm{O}$ arremate do texto é dado com uma síntese da revisão literária dos modelos comportamentais aplicados em pesquisas que investigaram o comportamento de pedestres em áreas urbanas, com foco no comportamento de travessia.

\subsection{O PEDESTRE}

Em muitas situações diferentes a definição de pedestre parece estar subentendida, transmitindo uma ideia de que o conceito de pedestre é claro e invariável, para qualquer pessoa em qualquer situação. Essa definição é essencial, pois o conceito de pedestre, se não deixado explícito, pode tornar-se bastante polêmico, principalmente na aplicação da legislação correlata e na escolha de parâmetros e critérios para projetos. 
O Código de Trânsito Brasileiro (CTB, 1997) menciona o termo pedestre em vários artigos, mas não deixa clara a sua conceituação, nem mesmo no glossário, existente no final do texto, há uma definição da palavra. É necessário encontrar uma conceituação para a palavra pedestre que represente a realidade global deste termo.

A Associação Brasileira de Normas Técnicas (ABNT, 1989), define pedestre como "toda a pessoa que anda a pé, que esteja utilizando-se de vias terrestres ou áreas abertas ao público, desde que não esteja em veículo a motor, trem, bonde, transporte animal ou outro veículo, ou sobre bicicleta ou animal". Na mesma norma existe um registro para "Veículo Pedestre", cuja definição é: "veículo acionado por pessoa, mediante o qual um pedestre pode deslocar-se de maneira diferente da marcha, ou mediante o qual um pedestre pode mover outro pedestre de um lugar a outro. Inclui berço sobre rodas, cadeira de rodas, carrinho deslizador de criança, patim de rodas e patinetes".

O Plano Diretor para Pedestres da cidade de Portland (PORTLAND'S PEDESTRIAN MASTER PLAN, 1998), define em seu glossário o pedestre como uma pessoa andando a pé, uma pessoa dirigindo um carrinho de mão, uma pessoa que viaja sobre, ou puxa uma carroça, trenó, patinete, triciclo, bicicleta com rodas de menos de 14 polegadas de diâmetro, ou condução semelhante, como patins, skate, cadeira de rodas ou carrinho de bebê.

Para a cidade de Berkeley (2010), no estado da Califórnia, em seu Pedestrian Master Plan, o termo "pedestre" se refere a uma pessoa que passa de um lugar para outro, a pé e/ou com o uso de um dispositivo de mobilidade de apoio (quando a pessoa tem uma deficiência e/ou condição médica limitante). "Caminhando" ou "caminhar" são os termos usados para descrever esse movimento de um pedestre.

O Pedestrian Master Plan da cidade de Oakland (2012) utiliza a definição constante no código de veículos da Califórnia, seção 467: (a) O "pedestre" é qualquer pessoa que está caminhando ou que está usando um meio de transporte movido por força humana que não seja uma bicicleta. (b) "pedestre" inclui qualquer pessoa que utiliza uma cadeira de rodas, triciclo, ou quadriciclo autopropulsados ou motorizados, operados por portadores de necessidades especiais que, em razão de deficiência física, estiver impossibilitado de se mover como um pedestre, conforme especificado na subdivisão (a). Apesar de não especificar claramente uma definição para 
pedestre, o Chicago's Pedestrian Plan (2011) ilustra a variedade de tipos de pedestres (Figura 2.1) que deve ser considerada no planejamento de sistemas de circulação.

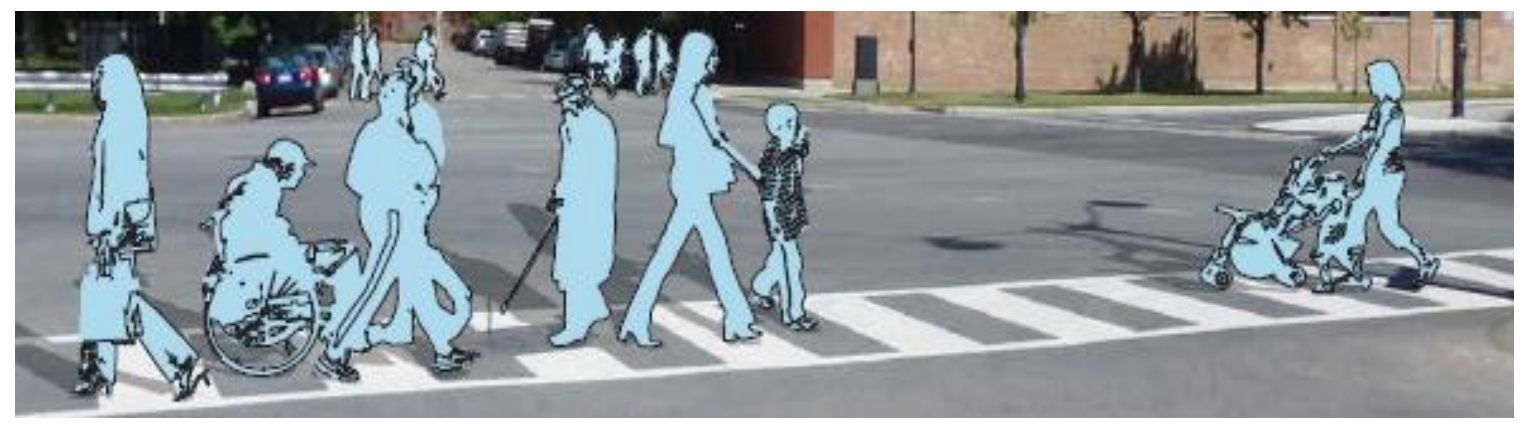

Figura 2.1 - Ilustração esquemática da variedade de pedestres. Fonte: Chicago Pedestrian Plan (2011).

A formulação do conceito de pedestre deve adotar três princípios básicos: a forma de deslocamento terrestre; a tração humana como força motriz preferencial; a velocidade de deslocamento, que deve ser de grandeza semelhante à desenvolvida por uma pessoa a pé. Assim sendo, neste trabalho, serão consideradas pedestres as pessoas que se deslocam em espaços urbanos públicos:

$\Rightarrow$ Andando a pé.

$\Rightarrow$ Utilizando equipamentos especiais (autopropulsados ou motorizados) que possibilitem a mobilidade para as pessoas que, em razão de deficiência física, estiverem impossibilitadas de se moverem andando a pé, desde que esses equipamentos não ultrapassem a velocidade média produzida na marcha de caminhada.

$\Rightarrow$ Trabalhando com carrinhos na limpeza urbana (garis, catadores) ou na venda de produtos (vendedores ambulantes).

$\Rightarrow$ Nos veículos utilizados por crianças e que desenvolvem baixas velocidades como carrinhos de bebê, de passeio e velocípedes.

A partir da definição do conceito de pedestre, pode-se discorrer a respeito das características destes indivíduos e da forma como eles se movimentam, inseridos no contexto das pessoas que se deslocam em ambientes urbanos públicos, tais como as ruas, cruzamentos, calçadas, praças, estações de transporte público, etc. 


\subsubsection{O Ato de Caminhar}

Andar de pé, caminhar e observar o horizonte no alcance máximo da sua altura talvez seja o maior diferencial entre a espécie humana e as demais no reino animal. Esta prova da "evolução" do homem, sem dúvida, é uma conquista vinda da necessidade de conhecer o ambiente e se integrar a ele. Para as crianças e adolescentes, o andar proporciona uma sensação de independência e liberdade que não é possível com outros modos de transporte. Para o idoso, caminhar é um meio eficaz para manter-se ativo, fisicamente e socialmente. Com exceção dos dispositivos para melhorar a mobilidade das pessoas portadoras de necessidades especiais, caminhar geralmente não exige nenhum equipamento especial. Assim, a caminhada é o mais barato de todos os modos de deslocamento. Andar a pé é a forma mais antiga e amplamente acessível de transporte e acesso à recreação.

A fim de se compreender quão complexo é o "simples" ato de andar, Magalhães et al. (2004) enfatizam as seguintes dimensões:

(i) Andar como Comunhão com o Ambiente: Andar põe o indivíduo numa posição vulnerável perante o meio que o cerca. Sons, odores, texturas, cores, estimulam todos os sentidos.

(ii) Andar como Elemento de Convivência/Sociabilidade: dada a condição de vulnerabilidade a que está exposto o pedestre, o andar é um meio de desenvolver relações de sociabilidade e convivência.

(iii) Andar como Elemento de Sobrevivência: andar é uma habilidade ancestral do ser humano, diretamente relacionada à sua sobrevivência. Os nômades urbanos (a exemplo dos catadores de lixo, vendedores ambulantes e mendigos) são personagens característicos desta dimensão.

(iv) Andar como Preservação da Saúde/Lazer: andar é a forma mais natural e acessível de exercício físico e, nos últimos anos, tem apresentado crescente popularidade dentre indivíduos das mais diversas idades.

(v) Andar como Ferramenta de Percepção Estética do Mundo: o andar é e pode ser utilizado como elemento de transformação simbólica do espaço.

(vi) Andar como Meio de Transporte: considera-se o andar como um meio secundário, complementar aos demais modos. 
Uma vez observadas as diversas dimensões assumidas pelo andar, pode-se perceber quão complexo pode ser o comportamento de um pedestre, e porque as simplificações na descrição deste comportamento podem conduzir a incompreensões e erros nas análises. Em muitos estudos tem-se o hábito de considerar os deslocamentos a pé como um modo de transporte secundário, complementar. No entanto, partindo do conhecimento de que todo tipo de deslocamento depende em algum momento do modo a pé, e que o modo a pé é o único modo capaz de começar e terminar, sozinho, um deslocamento, cabe aqui citar a proposta de inversão de conceito feita por Magalhães et al. (2004): "andar é o meio de transporte mais importante, sendo os demais modos extensores e complementares do andar, maximizando-o". Andar não requer tarifa, combustível ou licença. Para aqueles que não podem pagar por outros modos de transporte, a capacidade de andar com segurança é essencial. Entretanto, definir dentre tantas formas de andar o indivíduo que representa o pedestre não é tarefa fácil, mas se torna essencial para a evolução e foco do presente trabalho.

\subsubsection{A diversidade dos pedestres}

Tal qual a diversidade das pessoas que habitam uma cidade, a diversidade dos pedestres é muito vasta. Desde os primeiros passos, o ser humano identifica com prazer a liberdade de seguir os seus caminhos. Andar pode ser um meio de atingir universos inexplorados por uma criança assim como promover a mobilidade e a integração social dos idosos, ou seja, a maioria das pessoas está ou pode se tornar apta a se deslocar a pé. Além da idade, outras diversidades, como a cultural, proveniente das interações dos indivíduos com seus grupos sociais e das trocas realizadas por cada um com o ambiente que o cerca, também exercem influência nas características dos pedestres.

As diversidades citadas farão com que um mesmo indivíduo se comporte de forma diferente dependendo do estágio de ciclo de vida em que ele se encontra e do seu desenvolvimento histórico-cultural. Se imaginarmos os grandes períodos em que normalmente tem sido dividida a vida humana: a infância, a adolescência, a idade adulta e a velhice - e a associação de características, comuns a todas as pessoas e todos os grupos humanos, relacionadas a estas fases, poucas respostas teremos em relação ao comportamento destas pessoas como pedestres. Por exemplo, uma pessoa de 70 anos é considerada idosa em grande parte do mundo. Porém, se observarmos várias pessoas com essa mesma idade se deslocando por ruas e calçadas de um grande centro urbano, serão claramente perceptíveis padrões de comportamento distintos, pois 
a pessoa que nasceu e cresceu neste ambiente urbano certamente será mais assertiva e confiante ao realizar seus deslocamentos do que uma pessoa que migrou da área rural para a urbana já em idade avançada.

Nunca se experimenta os sentimentos de maneira pura, mesmo que somente às vezes as pessoas estejam conscientes de suas conexões contextuais (OLIVEIRA, 2003). A forma de pensar, que junto com o sistema de conceitos nos é imposta pelo meio que nos rodeia, inclui também nossos sentimentos. A abordagem da perspectiva histórico-cultural tem um importante papel já que fornece aos indivíduos, inseridos em diversos grupos culturais, nos diferentes momentos históricos, um conjunto de categorias concretas para definir seus conteúdos.

O meio ambiente também representa uma diversidade, pois fornece ao homem inúmeras informações sensoriais, a exemplo de formas, texturas, cores, cheiros, sons, iluminação, dentre vários outros, que possibilitam a pessoa analisar, sem tomar consciência disso necessariamente, os padrões que se modificam na proporção em que ela se movimenta. É como se o indivíduo estivesse constantemente "estudando" o que acontece à sua volta e o conteúdo de tais "estudos" pessoais vão formando o seu conhecimento a respeito do mundo.

Associado ao conhecimento que o homem vai adquirindo sobre o mundo, destacam-se as contribuições próprias do sujeito pela percepção. Essas contribuições se dão mediante as habilidades construtivas, a fisiologia e a experiência de quem percebe (BARBOSA, 2010). Pelas habilidades construtivas, o homem lança hipóteses sobre o que olha à medida que se movimenta, antecipa o que ocorrerá em seguida, armazena dados na memória e reúnem todas essas informações em sua bagagem perceptiva, sendo todo esse processo contínuo no decorrer da vida do homem. Pela fisiologia, devem ser consideradas limitações perceptuais entre as pessoas, assim como diferenças entre percepções. Por fim, as experiências passadas dos indivíduos interferem de forma relevante no modo como eles interpretam os estímulos ao seu redor. As cores, formas e tamanhos dos objetos no trânsito também são percebidos como sendo constantes pelo pedestre, o que lhe permite uma apreensão mais sólida e conjunta do ambiente ao seu redor. Além disso, tais objetos, mesmo quando apresentam qualquer variação em termos estruturais, são percebidos pelo pedestre de forma conservada em termos de suas singularidades. Assim, um automóvel com seu farol quebrado continua sendo percebido pelo pedestre como sendo um automóvel, ou seja, ele não perde sua originalidade. 
No que concerne à seletividade perceptual, para Barbosa (2010), entende-se que o pedestre, principalmente por influências culturais, tende a selecionar dados aspectos do trânsito privilegiados socialmente para se comportar de forma a atender às expectativas e valores de sua coletividade. Trata-se de um conjunto de preceitos, normas e valores que são transmitidos pela sociedade ao longo do desenvolvimento da pessoa (pedestre), de forma espontânea e que repercutem em suas condutas. Assim, fica claro entender, por exemplo, porque os pedestres se sentem seguros e voltam sua intenção para decidirem por atravessar vias utilizando a faixa de pedestres em algumas cidades nas quais, mesmo sem a utilização de semáforos, há uma cultura voltada ao respeito do espaço do pedestre.

\subsubsection{Atividades dos pedestres}

É inegável a influência do ambiente urbano no comportamento das pessoas que se movimentam por ele, com os pedestres não há como ser diferente. As atividades ao ar livre realizadas por pedestres em espaços públicos de uma cidade podem ser divididas em três categorias, cada uma das quais coloca exigências muito diferentes sobre o ambiente físico: atividades necessárias, atividades opcionais, e atividades sociais (GEHL, 1996).

As atividades necessárias incluem aquelas que são tidas como obrigatórias, como ir ao trabalho, às compras, esperar um ônibus ou uma pessoa. Entre outras atividades, esse grupo inclui a grande maioria dos pedestres, como as atividades deste grupo são necessárias, a sua incidência é influenciada apenas ligeiramente pela estrutura física. Essas atividades serão realizadas durante todo o ano, sob quase todas as condições, e são mais ou menos independentes do ambiente exterior, pois os participantes não têm escolha em relação à realização destas atividades.

As atividades opcionais, ou seja, aquelas atividades que só são realizadas se há um desejo de fazê-lo e se o tempo e lugar tornam possível são outra questão. Esta categoria inclui atividades como dar um passeio para respirar ar fresco, ficar de pé desfrutando a vida ao redor, ou sentado tomando banho de sol. Essas atividades acontecem apenas quando as condições exteriores são ótimas, quando o tempo e lugar são convidativos. Esta relação é particularmente importante na ligação com o ordenamento físico. Em outras palavras, essas atividades são especialmente dependentes de condições físicas exteriores. 
As atividades sociais são todas as atividades que dependem da presença de outras pessoas em espaços públicos. Incluem crianças brincando, os cumprimentos e conversas, atividades comunitárias de vários tipos e, finalmente, como a atividade social mais difundida, os contatos passivos, isto é, simplesmente ficar vendo e ouvindo outras pessoas. Essas atividades também podem ser denominadas de atividades "resultantes" porque as atividades sociais ocorrem de forma espontânea, como consequência direta das pessoas que se deslocam nos mesmos espaços. Isto implica que as atividades sociais são indiretamente apoiadas, acontecem sempre que são dadas melhores condições em espaços públicos para as atividades necessárias e opcionais.

De acordo com Gehl (1996), uma atividade social acontece a cada momento que duas pessoas estão juntas no mesmo espaço. Para ver e ouvir um ao outro, para se conhecer, é em si uma forma de contato, uma interação social. A relação das atividades desempenhadas pelos pedestres e o nível de dependência destas em relação ao espaço físico podem ser sintetizados como apresenta a Figura 2.2.

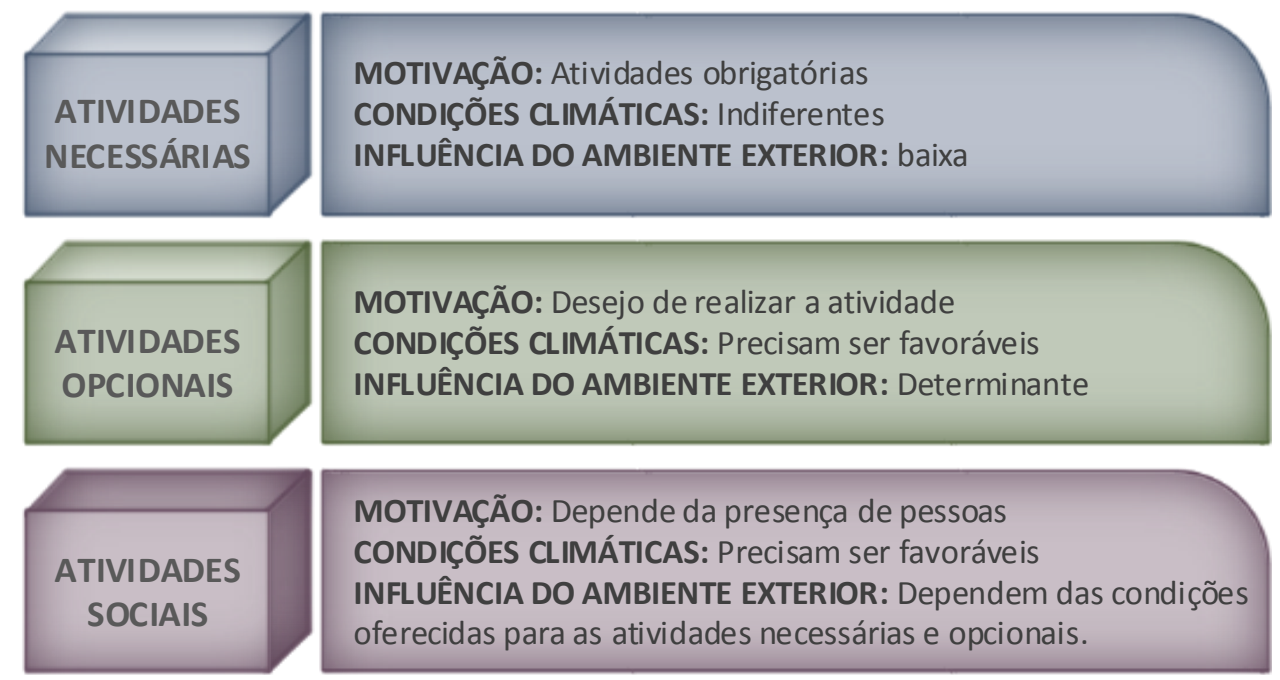

Figura 2.2 - Atividades desempenhadas pelos pedestres.

Fonte: adaptado de Ghel (1996).

É importante relacionar o deslocamento dos pedestres ao fator de dependência desta movimentação do ambiente urbano onde ela ocorre, pois, este conhecimento pode esclarecer os principais fatores intervenientes na decisão do pedestre sobre qual caminho percorrer, podendo auxiliar no planejamento da mobilidade. Outros enfoques classificatórios das atividades dos pedestres também são encontrados na literatura, mostrando que existem várias formas de 
perceber e entender as atitudes dos pedestres quando desejam se deslocar enquanto desempenham suas atividades rotineiras.

As atividades dos pedestres são classificadas por Papadimitriou et al. (2009) segundo uma estrutura hierárquica nos três níveis de planejamento, em que os pedestres possuem atividades no nível (i) estratégico, que correspondem à escolha do horário de partida e o planejamento das atividades que serão realizadas; (ii) tático, que correspondem à escolha da rota, e (iii) operacional, que correspondem aos processos de travessia, desvio de obstáculos e interação com outros pedestres. As atividades do nível operacional são utilizadas para reavaliar as do nível tático, como a escolha de rotas, conforme mostra a Figura 2.3.

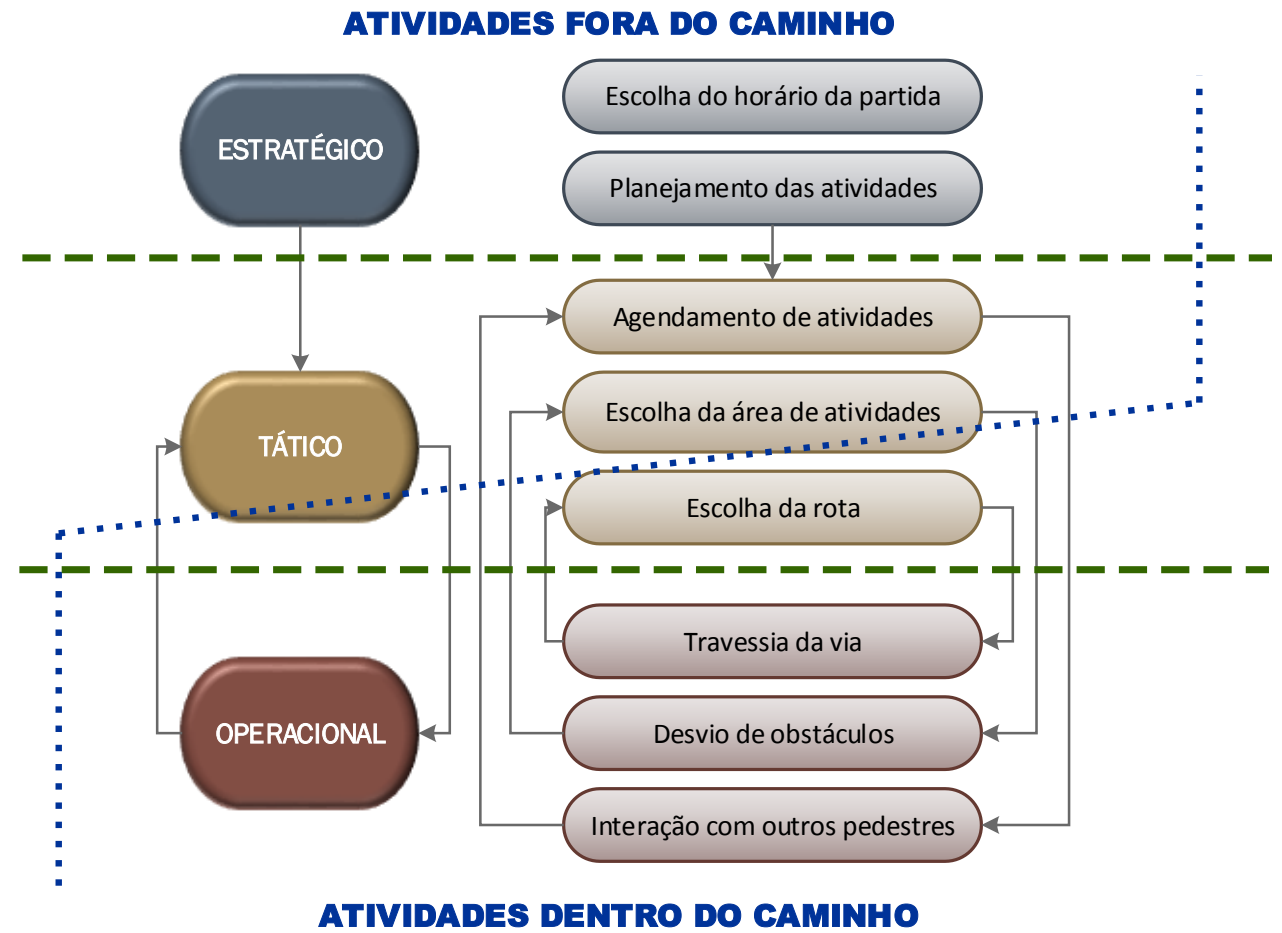

Figura 2.3 - Níveis de planejamento das atividades dos pedestres. Fonte: Papadimitriou et al. (2009).

A escolha de rotas realizada por pedestres pode representar um aspecto crítico quando existem múltiplos caminhos e travessias entre a origem e destino do deslocamento. A alocação de pedestres apresenta desafios especialmente porque estes percorrem áreas sem restrições de direção e sentido, diferentemente das redes utilizadas para a alocação de veículos. Na escolha de rotas de pedestres existem mais possibilidades de locais de travessia do que na de veículos. 
Os pedestres podem atravessar em interseções, travessias de meio de quadra e locais intermediários, não sinalizados. Nas vias em que existem brechas longas entre os veículos e não existem barreiras físicas, frequentemente os pedestres atravessam nos locais que minimizam a distância até o destino do seu deslocamento, independentemente da sinalização, ampliando o número de rotas possíveis.

\subsection{A INFraESTRUTURA PARA O PEDESTRE}

Para que as pessoas se desloquem, é preciso haver uma infraestrutura física na cidade que permita a circulação. Esta infraestrutura é formada pelas calçadas, pelas pistas e por equipamentos urbanos, como as passarelas, bicicletários e os terminais de integração de transporte público.

Os países em desenvolvimento - apesar das diferenças em seus contextos políticos, econômicos, sociais e culturais, que causam impactos relevantes tanto nos padrões de viagem das pessoas quanto nos processos de decisão e nas políticas correspondentes - compartilham condições semelhantes de transportes (VASCONCELLOS, 2000). Estas semelhanças podem ser observadas na dependência generalizada dos meios de transporte públicos e dos não motorizados (caminhada, bicicleta) e na iniquidade geral nas condições de transporte, com a maioria das pessoas submetidas a condições inadequadas de acessibilidade, segurança e conforto para realizar as atividades diárias. Situação distinta dos países industrializados, nos quais a disponibilidade de automóveis é elevada, e há uma distribuição mais equitativa do acesso aos meios de transporte públicos.

A constatação anterior reafirma a necessidade de investigação do comportamento dos cidadãos, imersos no seu contexto de desenvolvimento atual, para melhor planejar a circulação, pois as normas e projetos dos países industrializados que inspiram as ações dos países em ascensão precisam ser adaptadas a outra realidade. Assim, para contribuir com a formação de um senso crítico a respeito do deslocamento de pessoas andando a pé, é necessário conhecer o que já foi investigado dentro da temática.

A capacidade de prever os movimentos dos pedestres é valiosa em muitos contextos. A análise do comportamento das pessoas em situação de pânico é provavelmente o que motivou a grande 
maioria das atividades de pesquisa em campo. No entanto, é uma situação específica, não atingindo uma gama de aplicações mais ampla, pelo fato do comportamento do indivíduo ser motivado por um único objetivo (salvar a sua própria vida) e pode se tornar irracional, não sendo representativo da realidade. Capturar o comportamento de pedestres em situações "normais" é importante para a arquitetura, o planejamento urbano, o uso do solo, o marketing urbano, operações de tráfego e transporte público.

Os estudos que abordam os deslocamentos de pedestres geralmente se concentram em três temáticas:

i) Níveis de serviço oferecidos, que investigam praticamente características físicas do sistema (FRUIN, 1971; HCM, 1985; HCM, 2010).

ii) Qualidade do espaço, que adicionam a percepção dos pedestres sobre os aspectos físicos oferecidos através do estabelecimento de parâmetros (CARVALHO, 2006; FERREIRA e SANCHES, 2001; KHISTY, 1994; MONTEIRO e CAMPOS, 2012; MURALEETHARAN et al., 2004) e

iii) Dinâmica de deslocamento, que acompanham com imagens de vídeo ou rastreamento por satélite a movimentação dos pedestres (BIERLAIRE et al., 2003; HELBING et al., 2001; JACOBSEN, 2011; JARIYASUNANT et al., 2011; THERAKOMEN, 2001).

Ao analisar os estudos citados, pode-se perceber que a maioria deles são desenvolvidos com base em conceitos similares aos da engenharia de tráfego para a observação do fluxo de veículos, em que são observadas características da infraestrutura, o volume e a velocidade do fluxo de pedestres. São poucos os exemplos que abordam as características inerentes ao indivíduo como a tomada de decisão em relação ao deslocamento de forma direta.

\subsubsection{Decisões relativas ao deslocamento}

O comportamento humano é afetado por diversos aspectos psicológicos, biológicos, sociológicos, antropológicos, econômicos e políticos. Através do comportamento, a pessoa dá respostas a situações, criadas por estímulos internos ou externos, procurando satisfazer suas necessidades (BARBOSA, 2010). A tomada de decisão e a execução da alternativa selecionada manifestam o comportamento do indivíduo. Toda a forma de locomoção começa com o movimento do pedestre. A circulação a pé pode ser de percurso completo ou complementar a outra modalidade de transporte, seja para o acesso ao automóvel, ao ônibus, ao metrô, ao trem, 
à bicicleta. O planejamento urbano e de transportes deve partir do reconhecimento de que esta é uma modalidade de circulação básica que atinge grande parte das viagens realizadas nas cidades brasileiras.

O desenvolvimento de Sistemas Inteligentes de Transporte (Intelligent Transportation Systems - ITS) provocou atividades de pesquisa importantes no contexto da dinâmica de comportamento. Vários novos modelos (modelos de comportamento de viagem), novos simuladores (de tráfego e de condução) e novos sistemas integrados para gerenciar vários elementos dos ITS, têm sido propostos. Com relação aos pedestres, o foco tem sido principalmente em questões de segurança, e a modelagem dos movimentos detalhados de pedestres raramente tem sido considerada (BIERLAIRE et al., 2003).

Bierlaire et al. (2003) tentaram identificar os aspectos comportamentais da dinâmica de deslocamentos de pedestres, e descrever como o tema é abordado na literatura. $\mathrm{O}$ artigo apresenta ideias preliminares sobre o uso de modelos de escolha discreta para capturar o comportamento em estudo, e sua representação em um simulador microscópico de pedestres, projetado para suportar a análise de imagem e o rastreamento de objetos no contexto de vigilância por vídeo. Os autores encontraram várias analogias com simulação de tráfego.

No entanto, duas questões importantes são específicas para simulação de pedestres. Em primeiro lugar, o espaço físico não pode mais ser representado por uma rede, o que complica a utilização de modelos existentes. Em segundo lugar, e mais importante, a coleta de dados é mais complicada. Além disso, contrariamente aos dados de tráfego, os dados sobre os movimentos dos pedestres não são institucionalmente reconhecidos como úteis e, consequentemente, não são coletados em uma base regular, necessitando de uma série de pesquisas sobre comportamento para obter resultados realistas.

Jariyasunant et al. (2011) utilizaram smartphones para recolher dados de viagens dos participantes, que são utilizados para a análise de comportamento de viagem por meio de uma interface web. Combinada com a de interface de coleta de dados de viagens, a pesquisa feita com celulares não só motivou os participantes do estudo a participarem de pesquisas de longo prazo, mas também proporcionou um instrumento de utilidade política e estratégica com poderoso potencial, quando se trata da identificação da migração das viagens feitas com carros 
para outros modos mais sustentáveis de transporte. Na pesquisa, os aplicativos nos celulares dos participantes coletaram dados brutos do sensor e fizeram o upload para um servidor, baseado em nuvem, que salvou um banco de dados. Uma rotina periódica fez a leitura dos dados brutos, processou-os para inferir a origem e destino de viagem, e aplicou modelos de viagens de determinação, de modo a determinar se o participante foi de bicicleta, a pé, em um carro ou utilizando o transporte público.

Embora o uso de telefones celulares, de inferência de diários de viagem de GPS e dados de sensores permitam a baixo custo, pesquisas mais longas, elas também podem mostrar como o movimento de auto rastreamento, pode ser aproveitado pelas pessoas com interesse em participar da pesquisa por um longo período de tempo. Pode-se fornecer aos participantes, como valor direto em troca de seu esforço na coleta de dados, um feedback personalizado das estatísticas sobre os seus hábitos de viagem durante o levantamento. Além disso, o feedback pode ser usado para fornecer estatísticas, que influenciam a consciência das pessoas sobre as suas escolhas de rotas, modos de transporte e suas atitudes, com o objetivo de movê-los para um comportamento de transporte mais sustentável.

Choi e Sayyar (2012) investigaram a "caminhabilidade" (walkability) do ambiente construído e o comportamento dos pedestres em três bairros de Estocolmo na Suécia, observando detalhes como a densidade de pedestres e seus padrões de caminhar, as opções de rotas feitas nas viagens a pé e os diferentes fins ou destinos de locomoção que ocorrem na área. As viagens a pé observadas foram documentadas por suas finalidades específicas ou destinos. O estudo fornece uma descrição detalhada dos comportamentos dos pedestres, dos padrões de viajem em cada área, e uma visão sobre a compreensão da complexidade da atividade de andar e sua relação com o ambiente construído. A percepção do espaço pelos indivíduos é de interesse específico, tanto para promover instalações de pedestres que proporcionem espaços mais "caminháveis", quanto para estudos de diversidade urbana e planejamento da mobilidade.

\subsubsection{As instalações para os pedestres}

As facilidades para o deslocamento dos pedestres podem ser concebidas com bases em dados qualitativos, bem como em fatores quantitativos. Fruin (1971) apresentou um trabalho cujos procedimentos envolveram o uso de classificações de capacidade máxima para projetos voltados ao deslocamento de pedestres, abordando o conceito de nível de serviço. Para o autor, 
a capacidade de uma corrente de tráfego de pedestres invariavelmente é atingida nas maiores concentrações de pessoas combinada com restrições de velocidades de caminhada. Esta condição não é representativa de um ambiente humano confortável.

A utilização das fotografias de lapso de tempo (time-lapse) possibilitaram o estabelecimento da relação entre volume, velocidade e conveniência humana em diferentes locais de concentração de pedestres. Essas investigações formaram a base para a definição de seis níveis de serviço para o projeto de calçadas e escadas, esses níveis de serviço forneceram um método qualitativo para auxiliar novos projetos ou avaliar ambientes existentes. A partir do estudo de Fruin (1971), começaram a surgir normatizações e novos estudos voltados à circulação de pedestres, conforme é cronologicamente descrito adiante.

O manual americano Highway Capacity Manual (HCM) de 1985 fornece diretrizes para a concepção e avaliação de instalações de pedestres, semelhantes às de fluxo de veículos, utilizando o conceito de nível de serviço. A edição também recomenda que os fatores ambientais adicionais que contribuem para a experiência de andar e, portanto, a percepção do nível de serviço, tais como conforto, conveniência, segurança e atratividade, também devem ser considerados. No entanto, não são dadas orientações sobre como medir ou usar esses fatores ambientais para a concepção e avaliação de instalações de pedestres. Não há dúvida de que os fatores ambientais são de extrema importância para a concepção e avaliação de tais instalações, porque os pedestres, ao contrário de veículos a motor, não têm praticamente nenhum controle sobre a maioria destes fatores.

Khisty (1994) descreveu um método de avaliação de instalações de pedestres, que leva em conta vários fatores ambientais, observados por grupos independentes que estão familiarizados com a situação que está sendo avaliada. A avaliação dos fatores ambientais é realizada através de medidas de desempenho e estas, por sua vez, fornecem as características operacionais e do nível qualitativo de serviço da instalação que está sendo avaliada na visão dos seus usuários. Este nível de serviço qualitativo pode então completar o nível quantitativo de serviço da instalação, com base nas velocidades de fluxo e nas unidades de densidade, tal como descrito no HCM. A metodologia descrita pode ser mais eficiente no monitoramento e comparação do desempenho de tais instalações, bem como na alocação do orçamento de mudanças e melhorias. A aplicação prática da metodologia é descrita utilizando-se sete medidas de desempenho: atratividade, 
conforto, conveniência, segurança, seguridade, a coerência do sistema, e a continuidade do sistema.

O Highway Capacity Manual (HCM, 2010) apresenta termos importantes usados para capacidade de instalação de pedestres e termos indicadores para análise de nível de serviço (vale destacar que a edição citada do manual, não apresenta maiores contribuições em relação à edição anterior, publicada em 2000):

$\rightarrow$ Velocidade de percurso é a velocidade média de caminhar dos pedestres, geralmente expressa em unidades de metros por segundo $(\mathrm{m} / \mathrm{s})$.

$\rightarrow$ Fluxo de pedestre é o número de pedestres que passam em um ponto por unidade de tempo (p/min). Refere-se ao ponto de uma seção transversal, perpendicular ao percurso do pedestre.

$\rightarrow$ Fluxo de pedestre por unidade de largura é a média de fluxo de pedestres, por unidade de largura de passagem efetiva, expressa como pedestres por minuto por metro linear $(\mathrm{p} / \mathrm{min} / \mathrm{m})$.

$\rightarrow$ Densidade é o número médio de pedestres, por unidade de área numa passarela ou área de enfileiramento, expressa como pedestres por metro quadrado $\left(\mathrm{p} / \mathrm{m}^{2}\right)$.

$\rightarrow$ Espaço de pedestre é a área média prevista para cada pedestre em uma passarela ou área de enfileiramento, expressa em termos de metros quadrados por pedestres $\left(\mathrm{m}^{2} / \mathrm{p}\right)$. Isto é o inverso da densidade, e é muitas vezes uma unidade mais prática para análise de instalações de pedestres.

$\rightarrow$ Pelotão refere-se a um número de pedestres caminhando juntos num grupo, geralmente involuntariamente, como um resultado do sinal de controle e de outros fatores.

A relação fundamental entre a velocidade, densidade e volume de fluxo de pedestres é análoga ao fluxo de veículos. Com o aumento do volume e da densidade, diminui a velocidade de pedestres. À medida que aumenta a densidade e diminui o espaço para os pedestres, o grau de mobilidade cai, assim como a velocidade média de fluxo. O HCM (2010) apresenta ainda algumas diretrizes para auxiliar desenhistas de instalações para pedestres, usando a profundidade do corpo e largura dos ombros para os padrões mínimos de espaço, pelo menos implicitamente (Figura 2.4). 


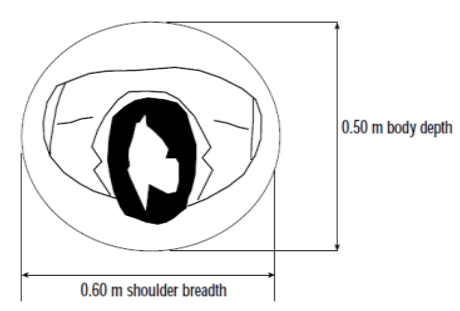

(a) Elipse de corpo de pedestre

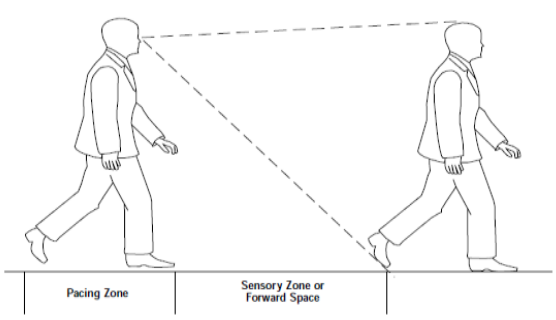

(b) Necessidade de espaço para o pedestre caminhando

Figura 2.4 - Requisitos de espaço para pedestres.

Fonte: Highway Capacity Manual - HCM (2010).

Segundo o referido manual, uma elipse corpo simplificada de 0,50 m x 0,60 m, com uma área total de $0,30 \mathrm{~m}^{2}$ é usada como a base para um espaço único para pedestres, como mostrado na Figura 2.4 (a). Isto representaria o espaço mínimo, prático para pedestres em pé. Para avaliar a facilidade de deslocamento dos pedestres, uma área de $0,75 \mathrm{~m}^{2}$ pode ser utilizada como zona de amortecimento, para cada pessoa. Um pedestre para andar necessita de certa quantidade de espaço frontal, conforme apresenta a Figura 2.4 (b). Este espaço para frente representa uma dimensão crítica, uma vez que determina a velocidade da viagem e o número de pedestres que são capazes de passar por um ponto, em um dado período de tempo.

A análise de fluxo de pedestres geralmente baseia-se na média das velocidades de grupos de pedestres andando. Dentro de qualquer grupo, ou entre grupos, pode haver diferenças consideráveis nas características de fluxo devido ao propósito da viagem, uso do solo, tipo de grupo, idade e outros fatores. Pessoas idosas e crianças pequenas tendem a andar em uma velocidade mais lenta do que outros grupos. Os pedestres que vão para o trabalho, usando dia após dia as mesmas instalações, andam em velocidades mais altas do que os que estão fazendo compras. O pedestre fazendo compras não só tende a andar mais lento do que os que estão de passagem, mas também pode diminuir a largura eficaz da passarela, parando para olhar as vitrines e carregando pacotes.

\subsubsection{A qualidade dos espaços para pedestres}

Uma das principais dificuldades no tratamento das questões relacionadas à qualidade dos espaços urbanos é a definição de um instrumento para avaliar o nível de serviço oferecido por esses espaços. A disponibilidade de um índice para avaliação da qualidade das calçadas e dos espaços públicos destinados aos pedestres permite que sejam identificados trechos de vias em 
que os pedestres estão mais expostos ao risco de acidentes e ao desconforto. Esse indicador do nível de qualidade, associado a outros fatores, tais como, volume de pedestres, poluição ambiental e importância econômica da região, pode determinar os pontos prioritários para intervenção, num programa de melhoria da qualidade ambiental dos espaços públicos para pedestres.

No Índice de Qualidade das Calçadas - IQC, desenvolvido por Ferreira e Sanches (2001), as características utilizadas para explicar as condições das calçadas foram: a largura total da via, a largura total da calçada, a largura efetiva da calçada, o tipo de calçada, a taxa de obstáculos, a taxa de área verde, o fluxo de tráfego, o fluxo de pedestres e o número de veículos estacionados. Foi realizada uma pesquisa em que os entrevistados avaliaram cada uma das características de diversos trechos de calçadas, utilizando uma escala de diferencial semântico. Utilizando o mesmo tipo de escala, foi feita também uma avaliação geral da calçada. Através de um processo da análise de regressão, foi obtida uma equação relacionando as características da calçada à qualidade geral da mesma. A metodologia proposta neste trabalho se desenvolve em três etapas:

1. Avaliação técnica dos espaços para pedestres, com base em indicadores de qualidade, atribuindo-se a pontuação correspondente.

2. Ponderação desses indicadores de acordo com a percepção dos usuários (grau de importância atribuída a cada indicador).

3. Avaliação final dos espaços através de um índice de avaliação do nível de serviço.

O ambiente adequado para pedestres, segundo os autores, deve garantir espaço, conforto, segurança e, se possível, aspectos estéticos agradáveis durante a caminhada. Dentre os inúmeros atributos que podem descrever essas qualidades, cinco foram utilizados nesse trabalho: i) segurança; ii) manutenção; iii) largura efetiva; iv) seguridade e v) atratividade visual.

A segurança se refere à possibilidade de conflitos entre pedestres e veículos sobre a calçada. A manutenção indica os aspectos de qualidade do piso que facilitam ou não o ato de caminhar. A seguridade está relacionada com a vulnerabilidade dos pedestres a assaltos e agressões. A largura efetiva indica a existência de trechos contínuos de calçada com largura suficiente para o fluxo de pedestres. A atratividade está relacionada com os aspectos estéticos e com os atributos visuais do ambiente. A percepção de um indivíduo com relação a um ambiente se dá 
através de estímulos psicológicos, a partir dos quais se formam as atitudes (de acordo ou de desacordo) que são passíveis de mensuração. O conhecimento das atitudes de um indivíduo em relação a um ambiente permite fazer inferências acerca de seu comportamento. Pode-se utilizar para isso uma escala de atitudes, ao longo da qual os fenômenos a serem avaliados são representados, de acordo com algumas de suas propriedades ou qualidades (Figura 2.5).

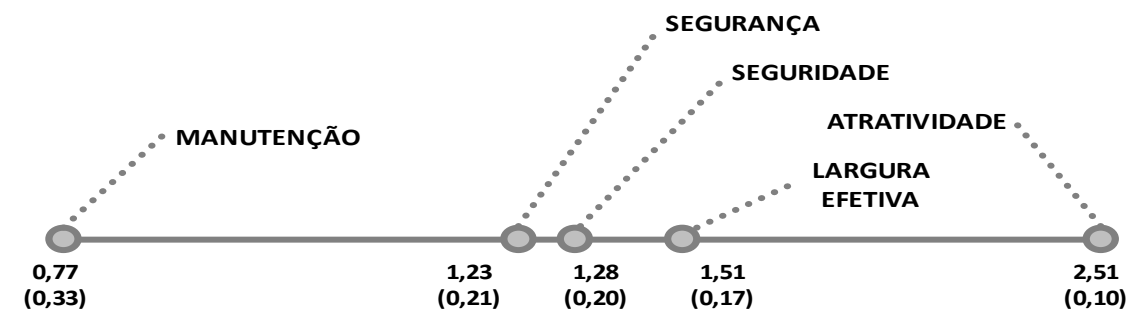

Figura 2.5 - Ponderação dos indicadores de qualidade das calçadas.

Fonte: adaptado de Ferreira e Sanches (2001).

$\mathrm{Na}$ pesquisa de Ferreira e Sanches (2001), dois indicadores destacam-se dos demais: manutenção e atratividade visual. Isto significa que, de acordo com a percepção dos entrevistados, o indicador manutenção é relativamente mais importante que os demais e o indicador atratividade visual é significativamente menos importante que os outros. A metodologia proposta neste trabalho procura, através de um índice, avaliar a qualidade das calçadas considerando aspectos ambientais percebidos e diferenciados pelos pedestres. Estes aspectos são avaliados tecnicamente e ponderados de acordo com a importância relativa de cada um deles, segundo o ponto de vista dos usuários.

O Índice de Qualidade das Calçadas foi obtido através da somatória da pontuação obtida na avaliação técnica pelos aspectos de segurança, manutenção, largura efetiva, seguridade e atratividade visual, multiplicados respectivamente, pelos fatores de ponderação de cada um desses aspectos. A importância atribuída pelos pedestres aos indicadores de qualidade mostra a expectativa de se conseguir calçadas que possuem boa qualidade nos aspectos mais básicos.

Helbing et al. (2001) investigaram o movimento de pedestres por avaliação de filmes de vídeo. Apesar da aparência por vezes mais ou menos "caótica" de comportamento individual dos pedestres, foram encontradas regularidades, algumas das quais se tornam mais visíveis nos filmes de lapso de tempo. Ao descrever estes comportamentos, também foram resumidos os resultados de estudos dos pedestres e algumas observações: 
1) Os pedestres mostram uma forte aversão em tomar desvios ao andar na direção desejada, mesmo que a rota direta esteja lotada. Consequentemente, pedestres normalmente escolhem a rota mais rápida para o seu próximo destino, que tem, portanto, a forma de um polígono. Se as rotas alternativas são do mesmo comprimento, um pedestre prefere aquela em que ele pode ir em frente por tanto tempo quanto possível e mudar de direção o mais tarde possível (desde que a rota alternativa seja mais atrativa, por exemplo, por causa de menos ruído, mais luz, um ambiente favorável, menos tempo de espera nos semáforos, etc.). Este comportamento, por vezes produz efeitos de "histerese", isto é, em alguns locais, os pedestres tendem a usar um caminho típico em certo ponto, mas outro caminho de volta.

2) Os pedestres preferem andar com uma velocidade individual desejada, o que corresponde à velocidade mais confortável a pé (que é definida pelo menor consumo de energia), enquanto não é fundamental ir mais rapidamente, a fim de chegar ao destino em menor tempo.

3) Os pedestres mantêm certa distância de outros pedestres e de limites de fronteiras (ruas, paredes e obstáculos). Esta distância é tanto menor quanto maior a pressa do pedestre, e também diminui com a densidade de pedestres crescendo.

4) Os pedestres, normalmente não refletem sua estratégia de comportamento em cada situação nova, mas agem de forma mais ou menos automática (como um motorista de carro experiente faz). Isto se torna óbvio quando pedestres causam atrasos ou obstáculos, por exemplo, entrando em um elevador ou trem, embora outros ainda estejam tentando sair.

Muraleetharan et al. (2004) propuseram um método para determinar o nível de serviço (LOS: Level-of-service) de um caminho de pedestres, com o auxílio da técnica conjunta. A técnica de análise conjunta é, segundo os autores, uma maneira poderosa de capturar o que os usuários realmente valorizam em um serviço ou produto. Ela foi usada neste estudo para entender como os pedestres valorizam as características de serviços por determinação das suas trocas (tradeoffs) entre os diferentes níveis. A análise conjunta estima um "sistema de valores" individual, que especifica o quanto um usuário coloca em cada nível dos atributos. Por conseguinte, utilizando a análise conjunta foram determinados quais atributos são importantes ou não para os pedestres, bem como as utilidades para cada nível de atributo. 
Foram estabelecidos oito atributos e três níveis para cada atributo por referência às normas de níveis de serviço. Os quatro fatores: largura e separação, obstruções, taxa de fluxo e presença de bicicletas foram identificados como fatores que afetam o ambiente da calçada. Espaço na esquina, instalações de facilidades de cruzamento, conversão de veículos permitida, e atrasos foram identificados como fatores que afetam o nível de serviço da faixa de pedestres.

O planejamento fatorial fracionário foi escolhido para este estudo. Esta abordagem tem vantagens, como a qualidade dos dados, riqueza de respostas fornecidas pelos utilitários em nível individual, além da possibilidade de realizar questionário em papel (Figura 2.6).



Figura 2.6 - Um dos 11 perfis utilizados na pesquisa de Muraleetharan et al. (2004).

Os autores concluíram que há uma tendência de aumentar a nota atribuída por uma pessoa, a uma calçada, à medida que o valor da utilidade total da calçada cresce. A utilidade total é um valor que pode ser explicado pela variabilidade das notas dos pedestres a uma determinada calçada.

Carvalho (2006), com o intuito de procurar refletir melhor o comportamento dos pedestres, em suas caminhadas sobre as calçadas, propôs a realização de um estudo detalhado sobre o nível de serviço das calçadas, considerando a influência dos aspectos físicos, geométricos e operacionais de uma via (inclusive a presença de ciclistas) sobre os pedestres, procurando 
mostrar quais os principais parâmetros que influenciam a caminhada. A pesquisa de campo (Figura 2.7) desenvolvida se mostrou uma sofisticação da pesquisa de Muraleetharan et al. (2004).

Com a pesquisa de opinião, Carvalho (2006) pretendeu definir parâmetros para projetos de calçadas que traduzam um melhor nível de satisfação aos pedestres, considerando os aspectos geométricos, físicos, operacionais e seções distintas de calçadas da via observada. A obtenção desses parâmetros pode auxiliar no planejamento de calçadas, levando em conta a perda de qualidade para deslocamentos dos pedestres provocada pelos ciclistas que invadem a calçada.

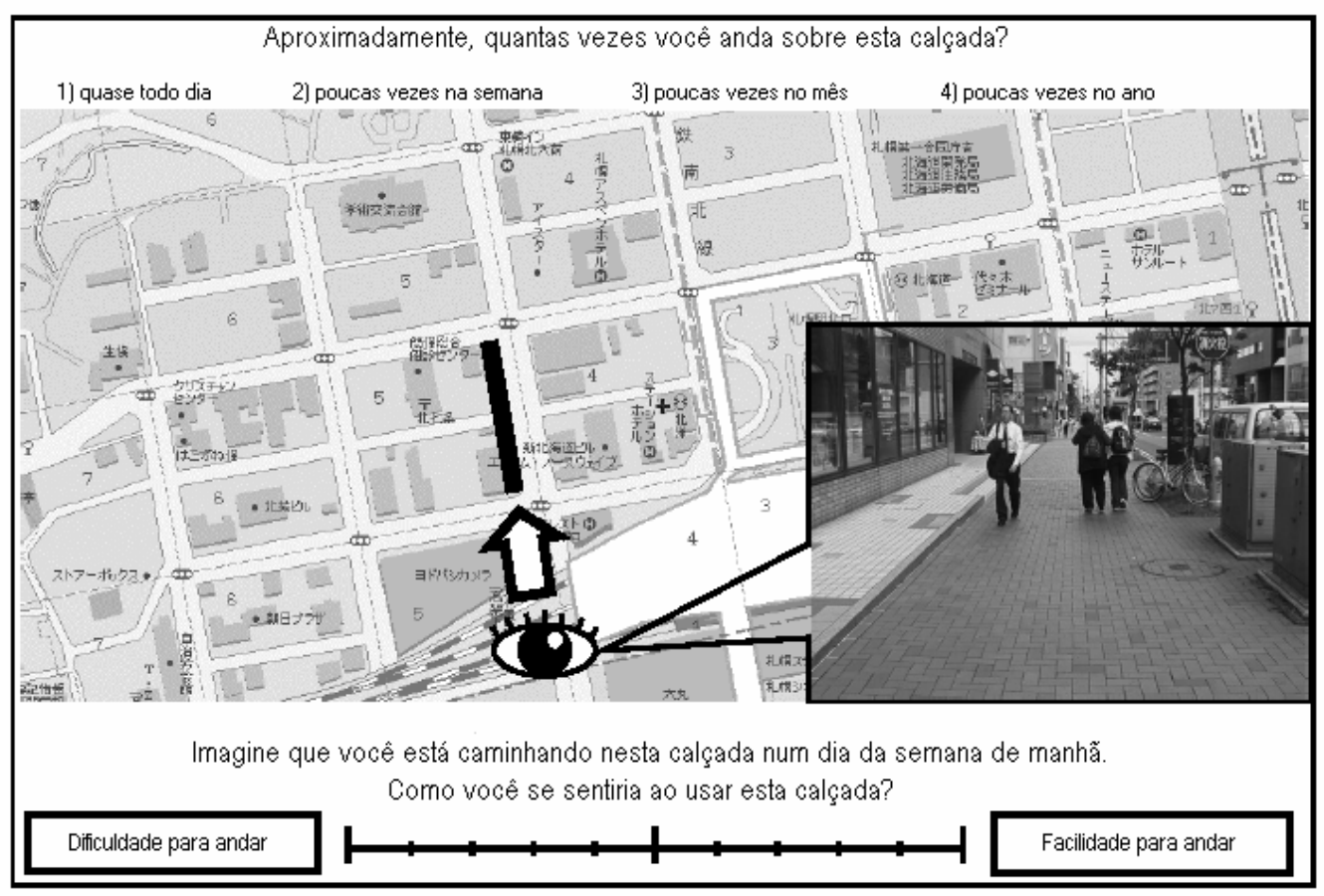

Figura 2.7 - Formulário da pesquisa de campo feita por Carvalho (2006).

Todos os estudos relacionados neste item colaboram com o conhecimento das instalações necessárias para propiciar o deslocamento dos pedestres de acordo com as aspirações das amostras de pessoas investigadas. Mas auxiliam somente na caracterização de um espaço físico melhor adaptado aos padrões de movimentação e deslocamento dos pedestres. Mas nenhum desses estudos abordam as necessidades inerentes da interação pessoa - espaço físico que a mobilidade urbana exige. 


\subsection{O AMBIENTE}

Existem atualmente estudos que buscam analisar o comportamento humano no trânsito, contudo, em sua maioria, tais estudos estão focados na ótica do condutor de veículo automotor. Por outro lado, existem estudos (FERREIRA e SANCHES, 2001; MAGALHÃES et al., 2004; MURALEETHARAN, 2004; PAPADIMITRIOU, 2012) que investigam o pedestre, principalmente envolvendo aspectos conjuntos dos deslocamentos, como qualidade do espaço físico, aliada à percepção do espaço pelo usuário, que caracterizam a interação do pedestre com o ambiente de circulação.

O comportamento humano no trânsito e, em especial, o comportamento do pedestre, está ligado aos processos que os psicólogos denominam como comportamento ambiental e aos que os estudiosos de transportes denominam comportamento de viagem. O conhecimento da percepção do espaço de deslocamento dos pedestres, aliado à identificação física deste espaço na área de estudo, traz ao pesquisador uma indicação das formas de realização das viagens dos pedestres neste local, podendo contribuir para a determinação de condições mais favoráveis ao deslocamento das pessoas, principalmente durante o acesso ao sistema de transporte público.

Entender o comportamento complexo dos pedestres, significa aprender sobre o comportamento individual das pessoas que circulam nas cidades, para compreender a relação entre as atividades, os movimentos e as atitudes do pedestre no espaço urbano. Magalhães et al. (2004) citam em seu trabalho alguns fatores intervenientes no comportamento do pedestre:

$\rightarrow$ Familiaridade com a área: é o conhecimento prévio que o indivíduo tem do ambiente, ou seu "mapa mental".

$\rightarrow$ Riscos potenciais: é a percepção de perigos existentes no ambiente.

$\rightarrow$ Continuidade do espaço: é a fluidez do espaço, tanto visualmente quanto morfologicamente, facilitando o deslocamento e "navegação" do pedestre através dele.

$\rightarrow$ Facilidade de apreensão do espaço (legibilidade): é a facilidade que o espaço oferece à elaboração do "mapa mental” e, portanto, na familiarização com a área.

$\rightarrow$ Pressão social: pressão exercida pelo sistema ou ordem social no sentido da exigência de adoção de um determinado comportamento ou conduta por parte de seus componentes. 
O processo de determinação do comportamento dos pedestres envolve a interação de elementos internos e externos ao indivíduo ou grupo (Figura 2.8). Segundo Magalhães et al. (2004) o objetivo do deslocamento interage com a bagagem cultural, vivencial do indivíduo (pedestre) selecionando um posicionamento específico. O posicionamento determina o tipo de comportamento através da definição do contato com o mundo e é caracterizado por uma série de tendências de comportamento e vieses de percepção. Influencia, portanto, na intensidade dos efeitos dos estímulos oriundos dos elementos componentes do espaço sobre o indivíduo ou grupo, majorando-os ou minorando-os dependendo do caso e determinando que viés de comportamento o indivíduo adote.

O posicionamento, desta forma, funciona como um filtro de ordem psicológica através do qual o indivíduo é capaz de perceber no mundo que o cerca e determina as linhas gerais de sua resposta ao ambiente (comportamento). No entanto, ao mesmo tempo em que o posicionamento define a qualidade do contato com o ambiente, este o altera. Este processo de alteração/redefinição ocorre em dois níveis: sobre o posicionamento, alterando a condição momentânea do indivíduo em relação ao ambiente; e sobre o conjunto de valores, expectativas e vivências, influenciando o próprio indivíduo e seu comportamento futuro, uma vez que o posicionamento é resultante desta bagagem cultural, vivencial.

Portanto, quando se considera o comportamento do indivíduo ou grupo dentro de um dado ambiente, dois pontos-chaves devem ser considerados (MAGALHÃES et al., 2004): o primeiro, o posicionamento, na medida em que ele é o filtro pelo qual se percebe e responde com o mundo a sua volta; e segundo, o próprio ambiente, na medida em que ele exerce influência sobre o posicionamento e o próprio indivíduo. 


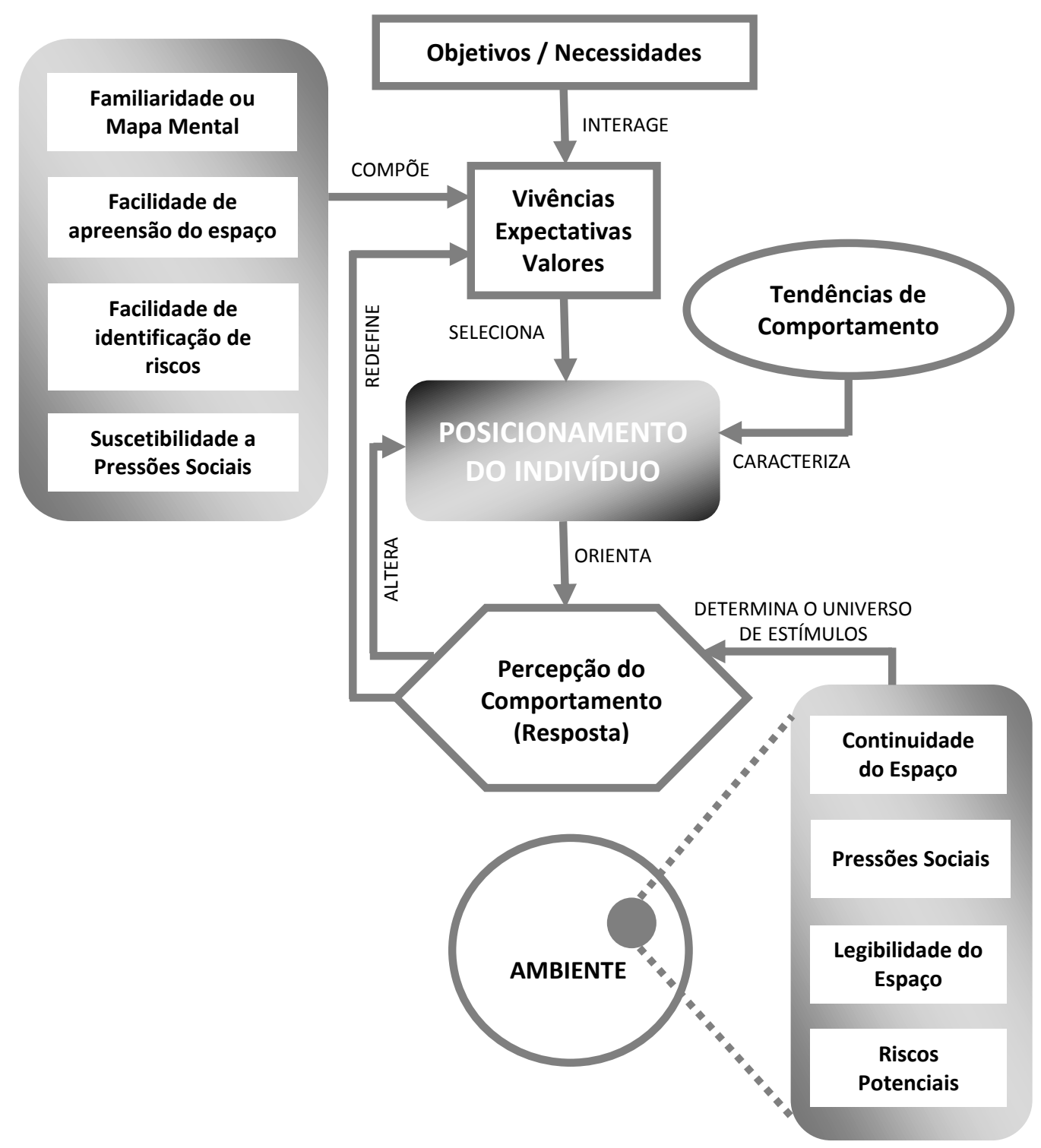

Figura 2.8 - Proposta de Modelo do Processo de Determinação do Comportamento do Pedestre. Fonte: Magalhães et al. (2004).

\subsubsection{A percepção do ambiente}

O comportamento dos pedestres é baseado na capacidade de tomar a decisão correta no momento certo. Esta atividade conta com a compreensão da situação, portanto, com o conhecimento da situação. A percepção da situação é composta de três níveis interdependentes: percepção dos elementos que cercam no ambiente, a compreensão do seu significado e a antecipação, ou seja, a projeção de seu status em um futuro próximo (TOM e GRANIÉ, 2011). A faceta núcleo de conhecimento da situação, que deve preceder a tomada de decisões em situações dinâmicas, tem dois aspectos: as decisões são tomadas dentro de um curto período de tempo e dependem de uma análise continuamente atualizada da situação. Deve-se destacar que, 
a fim de facilitar a percepção da situação, as estratégias muitas vezes utilizadas consistem em focar a atenção sobre as características do ambiente, que são relevantes para uma situação específica.

A segurança no trânsito da população idosa foi pesquisada por Sant'anna (2006), seu objeto de estudo foi investigar as especificidades dos pedestres idosos como usuários do sistema viário. Como resultado do processo de construção do objeto de estudo, foram estabelecidos dois objetivos específicos: um com foco na visão dos próprios usuários idosos e, outro, com foco na visão dos especialistas de engenharia de tráfego. A primeira etapa da pesquisa, voltada para o primeiro objetivo, foi uma pesquisa de campo que envolveu o ponto de vista dos pedestres idosos. O objetivo desta etapa foi identificar as representações sociais dos pedestres idosos sobre o trânsito e analisar as implicações dessas representações na segurança e na mobilidade dessa população.

A análise dos resultados da primeira etapa da pesquisa indicou um acentuado potencial de exposição ao risco dos pedestres idosos que, embora percebam o ambiente de trânsito como hostil e inseguro, priorizam sua mobilidade, em detrimento da sua segurança. A segunda etapa envolveu uma consulta aos especialistas de engenharia de tráfego. $\mathrm{O}$ objetivo desta etapa da pesquisa foi identificar como estes especialistas avaliam estratégias visando a garantia da mobilidade e da segurança no trânsito dos pedestres idosos, priorizando aquelas mais adequadas para uma possível adoção em cidades brasileiras.

O Método de Análise Hierárquica foi utilizado por Sant'anna (2006), tendo como objetivo identificar como esses especialistas avaliavam estratégias visando garantir a mobilidade e a segurança no trânsito dos pedestres idosos, priorizando aquelas mais adequadas para uma possível adoção em cidades brasileiras. Foram estabelecidos três critérios de avaliação (custo, facilidade de implementação e facilidade de monitoração e avaliação) e propostos cinco conjuntos de estratégias (ações educativas, revitalização urbana, alternativas de transportes, melhorias no sistema de transporte público e intervenções de Engenharia de Tráfego). Os cinco conjuntos de estratégias identificadas no estudo refletem um quadro atual da revisão do estado da arte e da prática sobre o tema pesquisado. Cabe destacar a necessidade de combinar as estratégias para reforçar a eficácia dos resultados. 
Kaparias et al. (2012) investigaram a importância de determinados fatores específicos pessoais, contextuais e de projeto que afetam a percepção dos pedestres e motoristas para a utilização de espaços compartilhados (shared spaces). A parte principal do estudo foi realizada pela web na forma de duas pesquisas de preferência declarada, em que foram apresentados conjuntos de cenários para cada entrevistado, de atributos selecionados (e níveis correspondentes), para que a decisão fosse através de um binário ( $\operatorname{sim}$ / não) sobre se ele ou ela se sentiria confortável se movendo como um pedestre, ou se ele ou ela estaria disposto a usar a rua e partes da superfície compartilhada com os pedestres, como condutor do veículo. Cada cenário consistia em todos os sete atributos com um nível específico para cada atributo, sendo para pedestres: tráfego de veículos, tráfego de pedestres, zonas de segurança, condições da superfície, nível de luminosidade, paisagismo, facilidades de descanso e motoristas: tráfego de veículos, densidade de pedestres, crianças e idosos, tamanho do espaço, nível de luminosidade, tamanho do veículo, mobiliário urbano. A análise de regressão foi realizada com modelos logit para cada pesquisa.

Os resultados sugerem que os pedestres se sentem mais confortáveis em espaços que proporcione condições que garantam que a sua presença é clara para os outros usuários - essas condições incluem o baixo tráfego de veículos, o tráfego de pedestres elevado, boas iluminação e instalações para pedestres. Por outro lado, a presença de muitos pedestres e, em particular, de crianças e idosos, torna a situação desconfortável para os condutores e, portanto, aumenta a sua apreensão.

\subsubsection{O ambiente de travessia}

A movimentação dos pedestres corresponde ao comportamento do pedestre durante o deslocamento, incluindo a escolha da velocidade, a interação com outros pedestres e o desvio de obstáculos. Os pedestres apresentam diferentes características em relação à movimentação. A velocidade que cada pedestre deseja manter no seu deslocamento é uma das diferenças mais evidentes, especialmente ao avaliar grupos como crianças, idosos e portadores de necessidades especiais. Estes grupos geralmente apresentam velocidades inferiores à média dos pedestres.

Alguns estudos indicam que as velocidades em travessias são superiores às observadas em calçadas. As velocidades podem depender de fatores relacionados às características dos pedestres, como idade, sexo e motivo do deslocamento; e às características do ambiente, tais como a declividade e a possibilidade de conflito com outros modos em casos de travessias 
(JACOBSEN, 2011). Os modelos que representem a interação entre os pedestres de forma realista, reproduzindo fenômenos de auto-organização dos pedestres e velocidades compatíveis com fluxo na travessia, são importantes para garantir resultados realistas.

A aceitação de brechas representa o processo através do qual o pedestre decide o momento em que inicia a travessia em situações em que os veículos possuem prioridade. Os pedestres analisam o fluxo de veículos, estimam a duração das brechas e atravessam quando consideram a brecha longa o suficiente para garantir a travessia com segurança. A brecha mínima que cada pedestre aceita depende de diversos fatores como: faixa etária; sexo, tempo de espera, duração da brecha e do número de pedestres aguardando a travessia.

Segundo Sun et al. (2003), os pedestres geralmente aceitam brechas que permitam atravessar todas as faixas de tráfego em apenas uma etapa de travessia, sem parar entre elas. Em travessias com múltiplas faixas de tráfego, particularmente em locais com alto volume de tráfego, os pedestres não aguardam a liberação de todas as faixas para iniciar a travessia - brechas defasadas (rolling gaps). As travessias sinalizadas, onde os pedestres possuem preferência, são representadas especialmente por faixas de segurança. Nestes locais, os motoristas identificam a presença de pedestres que se aproximam da travessia e decidem, em função da sua velocidade e distância da travessia, se concedem a preferência de passagem ao pedestre.

Um estudo em duas fases foi conduzido por Havard e Willis (2012) para investigar o comportamento dos pedestres em uma travessia e a percepção do ambiente da travessia, antes e depois da instalação de uma faixa de pedestres em um estudo de caso em Edimburgo, Reino Unido. As pesquisas observacionais e por questionários indicaram que: (a) os pedestres foram significativamente mais propensos a usar o local demarcado para atravessar a rua, os tempos de espera para atravessar foram menores, e as velocidades de travessia foram mais baixas após a instalação da faixa; (b) as pessoas se sentiram mais seguras, menos vulneráveis ao tráfego e mais confiantes ao atravessar a estrada após a instalação da sinalização. Os resultados indicam que a instalação de uma faixa de pedestres delimitada como uma passadeira pode melhorar significativamente a travessia de pedestres e, portanto, melhorar a viagem a pé de forma geral.

Na decisão sobre dar preferência a pedestres, os motoristas avaliam diversos fatores. Entre eles são observadas a influência da idade do motorista; sexo do motorista; tipo de veículo; número 
de pedestres aguardando na travessia e existência de veículos dando preferência aos pedestres no sentido oposto (SUN et al., 2003). Os locais onde os pedestres apresentam comportamento assertivo, demonstrando claras intenções de atravessar, aumentam a probabilidade de veículos darem preferência aos pedestres, assim como a visibilidade no local e a predisposição dos motoristas em dar preferência. $\mathrm{O}$ tratamento da travessia influencia o comportamento dos motoristas, destacando que a existência de um dispositivo de sinalização, como um semáforo com a luz vermelha para os veículos, resulta no comportamento mais obediente.

Os pedestres possuem várias alternativas de escolha ao atravessar uma via no ambiente viário. No entanto, a decisão de onde e em que momento realizar a travessia é influenciada pelas condições de todo o ambiente viário. Do ponto de vista da engenharia de tráfego, os principais fatores que influenciam as perspectivas operacionais e de segurança dos usuários envolvem: a localização de preferência dos pedestres para a travessia, as condições sob as quais eles decidem atravessar a via e as características do fluxo viário. Contudo, a escolha do local para realização de uma travessia pelos pedestres pode estar relacionada a três fatores principais: o desejo do pedestre de percorrer uma menor distância, o desejo de realizar uma travessia no menor tempo e a necessidade de reduzir a exposição ao risco de acidentes (ARIOTTI, 2006).

A escolha de rotas realizada por pedestres não corresponde ao comportamento de pedestres na travessia, mas pode ser um aspecto crítico quando existem múltiplos caminhos e travessias entre a origem e destino do deslocamento. A alocação de pedestres apresenta desafios especialmente porque estes percorrem áreas sem restrições de direção e sentido, diferentemente das redes utilizadas para a alocação de veículos. $\mathrm{Na}$ escolha de rotas de pedestres existem mais possibilidades de locais de travessia do que na de veículos. Os pedestres podem atravessar em interseções, travessias de meio de quadra e locais intermediários, não sinalizados. Nas vias em que existem brechas longas entre os veículos e não existem barreiras físicas, frequentemente os pedestres atravessam nos locais que minimizam a distância até o destino do seu deslocamento, independentemente da sinalização, ampliando o número de rotas possíveis.

Segundo Sisiopiku e Akin (2003), que avaliaram a preferência dos pedestres na escolha do local da travessia, o principal fator identificado (por frequência de citações) em entrevistas com pedestres foi: (i) a posição da travessia em relação à origem e destino dos pedestres; (ii) a existência de semáforo e (iii) a existência de barreiras que impedissem a travessia em locais 
não sinalizados. Nas entrevistas feitas pelos pesquisadores, $41 \%$ dos pedestres indicaram que não tinham preferências em relação ao local de travessia, e que atravessavam em qualquer lugar que fosse conveniente. A partir destas constatações, percebe-se que fatores como a localização das travessias, existência de semáforo e existência de barreiras físicas, poderiam ser incorporados em modelos de escolhas de rotas para pedestres.

O desconhecimento das formas comportamentais do pedestre durante a travessia, pode induzir a equívocos na utilização de modelos auxiliares ao planejamento de transportes. Existem comportamentos frequentes de pedestres frente à situação de travessia, que devem ser considerados pelos modelos, para aumentar a qualidade dos estudos. Weberich, Pretto e Cybis (2012), descreveram os comportamentos de pedestres em momentos de travessia, baseados em observações e referências de literatura (Figura 2.9).

No estudo realizado por Weberich, Pretto e Cybis (2012), um fato comum à realidade brasileira é relatado no comportamento observado para travessia na faixa de segurança: o desrespeito ao espaço do pedestre representado pela faixa. Essa atitude de desrespeito pelos usuários do sistema viário, dificulta a observação de como se comporta o pedestre durante a travessia de uma via, na faixa de segurança, mas sem sinalização semafórica que interrompa o fluxo de veículos. A introdução das características reais deste comportamento pode causar mudanças significativas nas simulações que representam os deslocamentos dos pedestres. 


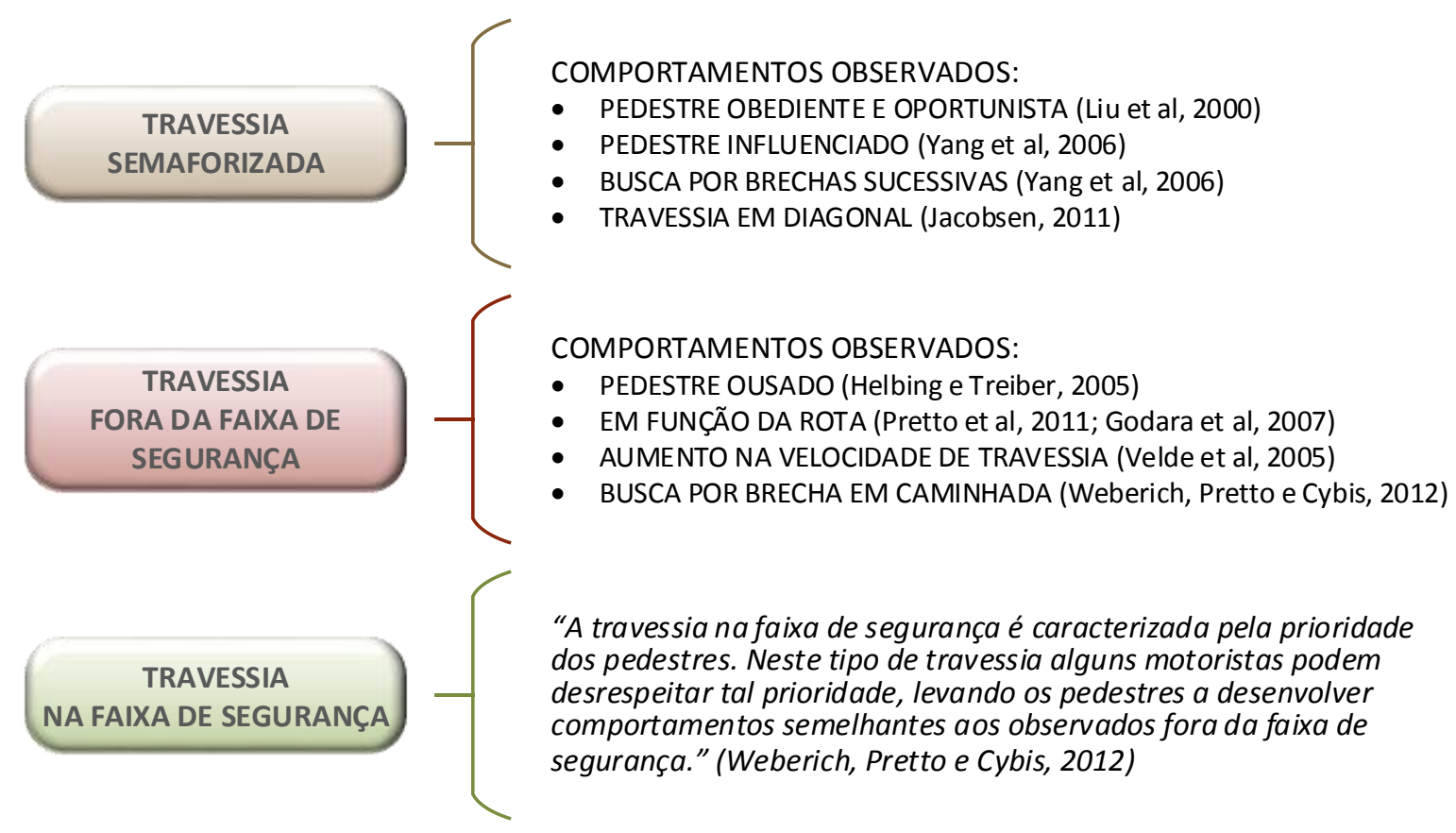

Figura 2.9 - Comportamentos observados para pedestres em momento de travessia. Fonte: Adaptado de Weberich, Pretto e Cybis (2012).

\subsection{CONSIDERAÇÕES SOBRE O CAPÍTULO}

$\mathrm{O}$ presente capítulo indicou que, ao realizar uma travessia, características ambientais e individuais podem influenciar o comportamento de pedestres. O objetivo do texto foi apresentar uma síntese de pesquisas que investigaram o pedestre, suas formas de deslocamento, a infraestrutura apropriada e a qualidade dessas estruturas.

O comportamento de andar, os padrões de movimento de pedestres, detalhes da viagem, que incluem origens, destinos e opções de rota, além de características individuais ajudam a identificar e conceituar o indivíduo pedestre. Apesar das semelhanças com o fluxo de veículos, em algumas características mais facilmente mensuráveis, em outras os fatores psicológicos como compreensão e conhecimento do ambiente de deslocamento podem ser mais representativos no entendimento do comportamento dos pedestres e das suas escolhas. 


\title{
3 TEORIAS DE ANÁLISE DO COMPORTAMENTO
}

\begin{abstract}
... vivemos simultaneamente em dois mundos distintos - um dominado pelas normas sociais e o outro, onde as normas de mercado fazem as leis.

As normas sociais são os pedidos amistosos que fazemos uns aos outros, estão envolvidas em nossa natureza social e em nossa necessidade de comunidade. As normas de mercado são comunicações argutas: salários, preços, aluguéis, juros, custos e benefícios.

Se analisarmos como as normas de mercado vêm, aos poucos, tomando posse de nossa vida nas últimas décadas, talvez venhamos a reconhecer que um retorno a algumas das velhas normas sociais pode não ser tão ruim. Poderia trazer, de fato, muito da velha civilidade de volta a nossa vida.
\end{abstract}

Dan Ariely (2008)

Os estudos de comportamento podem ter diversas abordagens, como a identificação dos indivíduos que possuem o comportamento estudado, a caracterização de um comportamento específico e a identificação de variáveis que afetam o comportamento. O presente estudo busca uma caracterização do comportamento dos pedestres durante a travessia na faixa tratando-se, portanto, de um comportamento específico.

Para nortear a pesquisa é necessária a identificação dos comportamentos pertinentes ao indivíduo "pedestre", assim como os fatores presentes no ambiente de travessia que afetam diretamente esse comportamento. Neste capítulo serão abordadas as teorias de análise do comportamento e da psicologia ambiental, na busca de identificar dentro das bases teóricas os procedimentos para análise do comportamento do pedestre no ambiente da travessia.

\subsection{Interação entre Pedestres, Motoristas e o Ambiente}

Devido às suas características, os pedestres apresentam, no ambiente viário, maior maleabilidade para circular do que qualquer outra modalidade de transporte, sobrepondo-se a todos os inconvenientes encontrados em seu trajeto. Contudo, as formas urbanas e a composição do ambiente viário desempenham um efeito crucial no comportamento de viagem dos pedestres.

Rozestraten (1988) analisou o trânsito como se fosse constituído por três sistemas que interagem entre si, sendo eles: o homem - o comportamento; a via - o ambiente que rodeia o pedestre ou o veículo; e o veículo - campo de informação e comunicação. Posteriormente, 
Günther (2003) expande esse conceito, incluindo um quarto elemento na interação: o meio ambiente - composto pela sociedade, suas normas sociais e leis.

O estudo do comportamento no trânsito não deve perder a perspectiva de reciprocidade entre o comportamento do participante do trânsito e seu ambiente, pois o ambiente físico, construído ou natural, exerce influência no comportamento do indivíduo e é influenciado por esse comportamento. A área da psicologia que busca explicar a relação entre comportamento, experiência humana e ambientes físicos é conhecida como Psicologia Ambiental. Quando aborda o contexto do trânsito, ela não fica restrita ao estudo da subjetividade dos participantes do sistema, mas sua inserção no contexto ambiental, do impacto do seu comportamento sobre o ambiente e do ambiente sobre seu comportamento (GÜNTHER, 2003).

Como já apresentado anteriormente, ao realizar uma travessia, diversas características podem influenciar o comportamento do pedestre. No entanto, as condições ambientais mais importantes que intervêm na escolha do local e do momento de iniciar uma travessia referemse diretamente aos aspectos físicos de cada localidade e às características de intensidade, composição e velocidade do fluxo veicular. Assim, os fatores potencialmente responsáveis por alterações nas conformidades de travessia podem ser classificados em duas categorias:

i) fatores viário-ambientais fixos - que representam as características locais da travessia e envolvem aspectos físicos de geometria e condições de entorno; e

ii) fatores viário-ambientais variáveis - que correspondem aos parâmetros que estão sujeitos a alterações em períodos distintos (ARIOTTI, 2006). Os fatores viárioambientais fixos e variáveis estão representados na Figura 3.1.

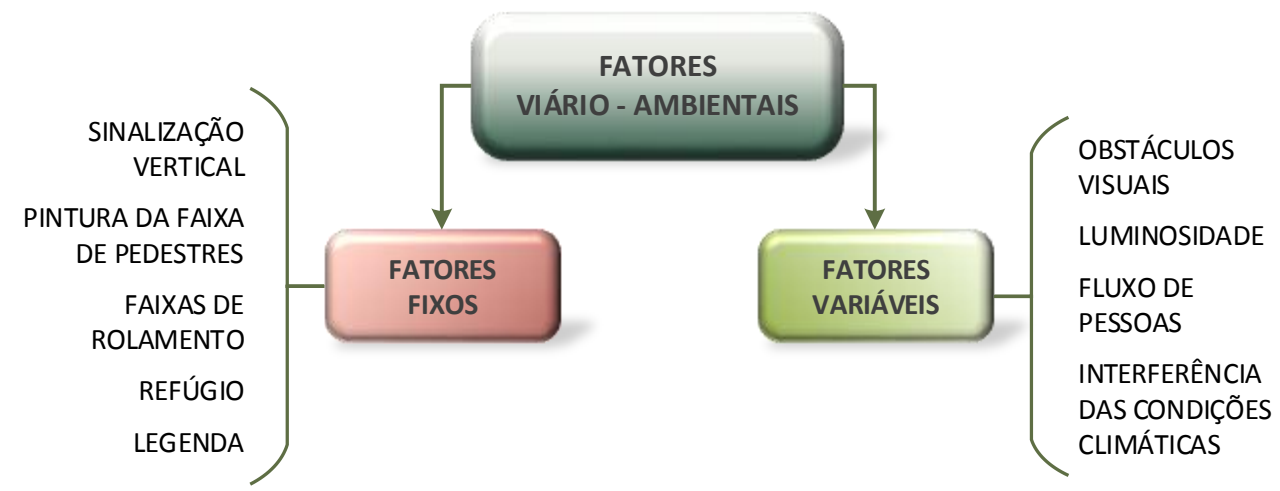

Figura 3.1- Fatores viário-ambientais que influenciam o comportamento do pedestre.

Fonte: Adaptado de Ariotti, 2006. 
A Teoria Geral dos Sistemas permite a análise do comportamento humano no trânsito como um sistema que resulta em ações nas diversas situações possíveis (excesso de velocidade, avanço no sinal vermelho, cruzamento de faixas de pedestre), bem como auxilia na identificação de fatores que influenciam o comportamento das pessoas. A Figura 3.2 ilustra alguns dos insumos do sistema que são processados, para que a decisão final resulte no comportamento no trânsito (THIELEN et al., 2007).

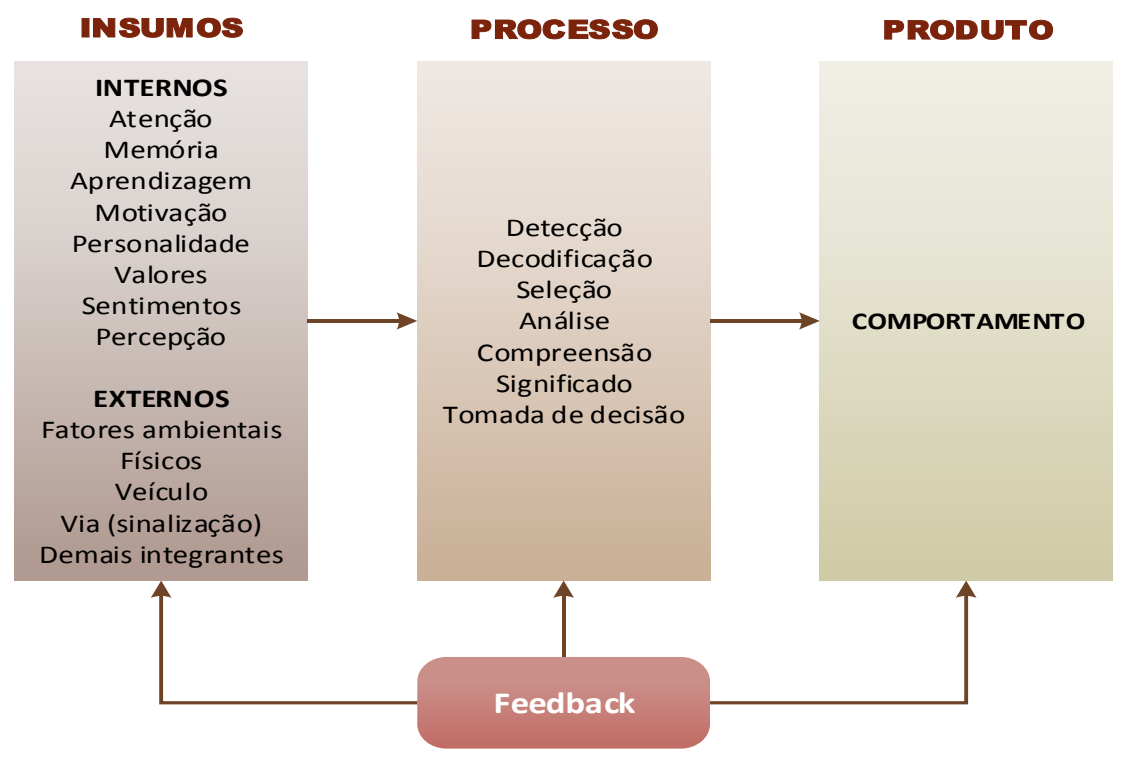

Figura 3.2 - Teoria Geral dos Sistemas aplicada ao comportamento no trânsito. Fonte: Adaptado de Thielen et al., 2008.

Embora os insumos apresentados detalhem fatores internos e externos, é importante enfatizar que não se tratam de fatores isolados, mas em interação. Da mesma forma, o processo representado destaca algumas ações encadeadas que fundamentam a tomada de decisão:

i) detecção das variáveis envolvidas - sejam estímulos do ambiente, sejam informações, como aquelas decorrentes da legislação;

ii) decodificação dos dados com base em variáveis individuais, grupais, culturais ou ideológicas;

iii) seleção de estímulos aos quais vai responder ou ignorar;

iv) análise das variáveis envolvidas seja em relação às consequências das opções de ação, seja em relação ao jogo de forças presente na situação;

v) compreensão das variáveis, dos estímulos e da relação entre eles no contexto;

vi) significado atribuído a cada um dos elementos presentes na situação e à interação entre eles. 
Após as ponderações sobre todo esse jogo de interações a partir de variáveis cognitivas, afetivas e dos possíveis resultados das ações que podem ser empreendidas, o indivíduo opta por tomar a decisão que resulta em determinado curso de ação. Para o entendimento do comportamento desse indivíduo deve-se levar em consideração: o contexto social e as representações; erros e violações; fatores psíquicos e sociais; o meio ambiente e a infraestrutura (ROCHA, 2006). Estas questões estão esquematizadas na Figura 3.3.

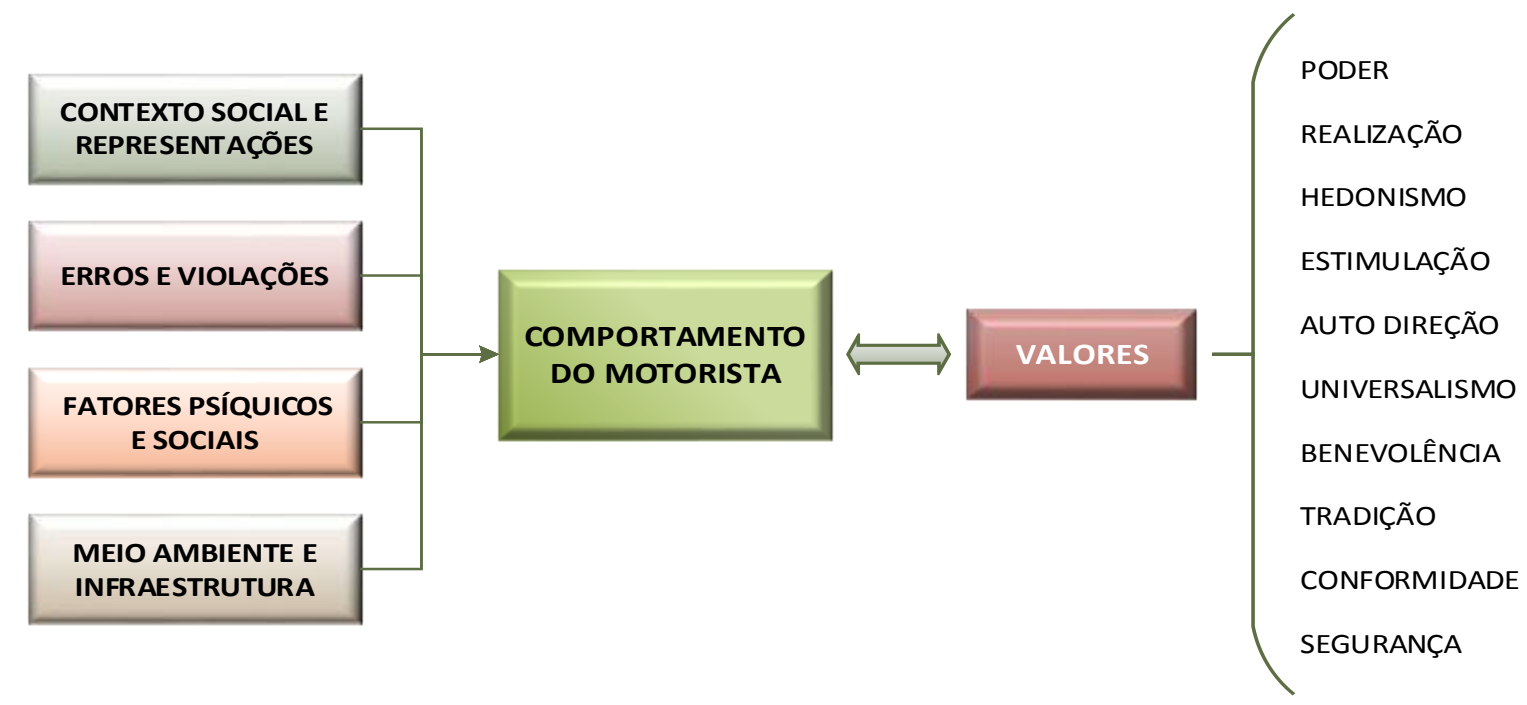

Figura 3.3 - Questões relacionadas ao comportamento e valores dos motoristas. Fonte: Adaptado de Rocha, 2006.

Quanto aos valores que interferem e influenciam no comportamento das pessoas no trânsito, Schwartz (1994) parte do seguinte raciocínio: para adaptarem-se à realidade de um contexto social, os grupos e indivíduos transformam as necessidades inerentes à existência humana e as expressam na linguagem de valores específicos, por meio dos quais podem então se comunicar. Mais especificamente, os valores representam, na forma de metas conscientes, as respostas que todos os indivíduos devem dar a três requisitos universais: o organismo, o grupo, e a interação de ambos, conforme é apresentado na Figura 3.4.

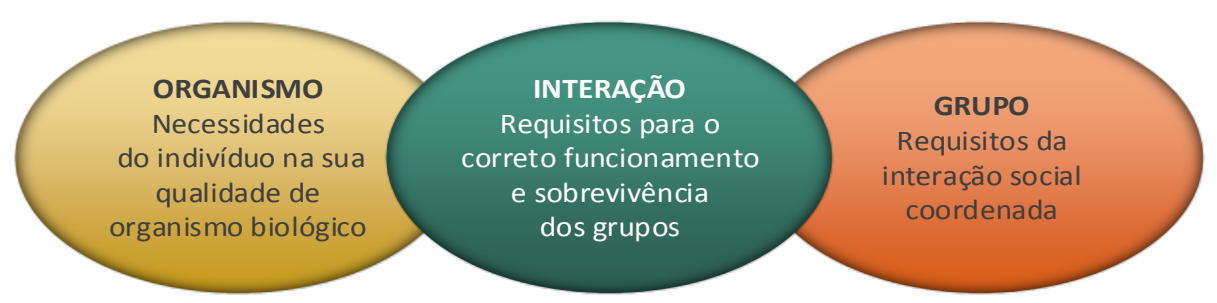

Figura 3.4 - Valores que interferem e influenciam no comportamento dos motoristas. Fonte: Adaptado de Schwatz, 1994. 
A análise dos valores representados na Figura 3.4, permite o entendimento da importância da definição dos requisitos para o correto funcionamento da interação entre os interesses dos grupos e dos indivíduos. Desta análise, fica claro que a interação entre pedestres e motoristas, no compartilhamento do sistema viário, necessita da definição de direitos e deveres de ambos, para que os deslocamentos urbanos aconteçam de forma segura e eficiente. Quanto ao comportamento específico em relação à faixa de pedestre, é preciso entender esse comportamento para conscientizar a população em geral, tanto pedestres quanto motoristas, da necessidade de reconhecimento e de respeito ao espaço e ao tempo do pedestre para a travessia das vias.

A abordagem sistêmica de segurança discutida pela Organização Pan-Americana de Saúde (OPAS, 2013) e apresentada na Figura 3.5 aborda os fatores de risco e medidas relacionadas aos usuários da via, aos veículos e ao ambiente viário de forma integrada. Essa abordagem tem se mostrado adequada e eficaz em vários lugares do mundo. A abordagem sistêmica de segurança para o trânsito reconhece que o transporte é importante para a sociedade, mas ressalta que a viagem deve ser segura para todos os usuários da via, pois eles interagem com as vias e veículos visando facilitar seu movimento.

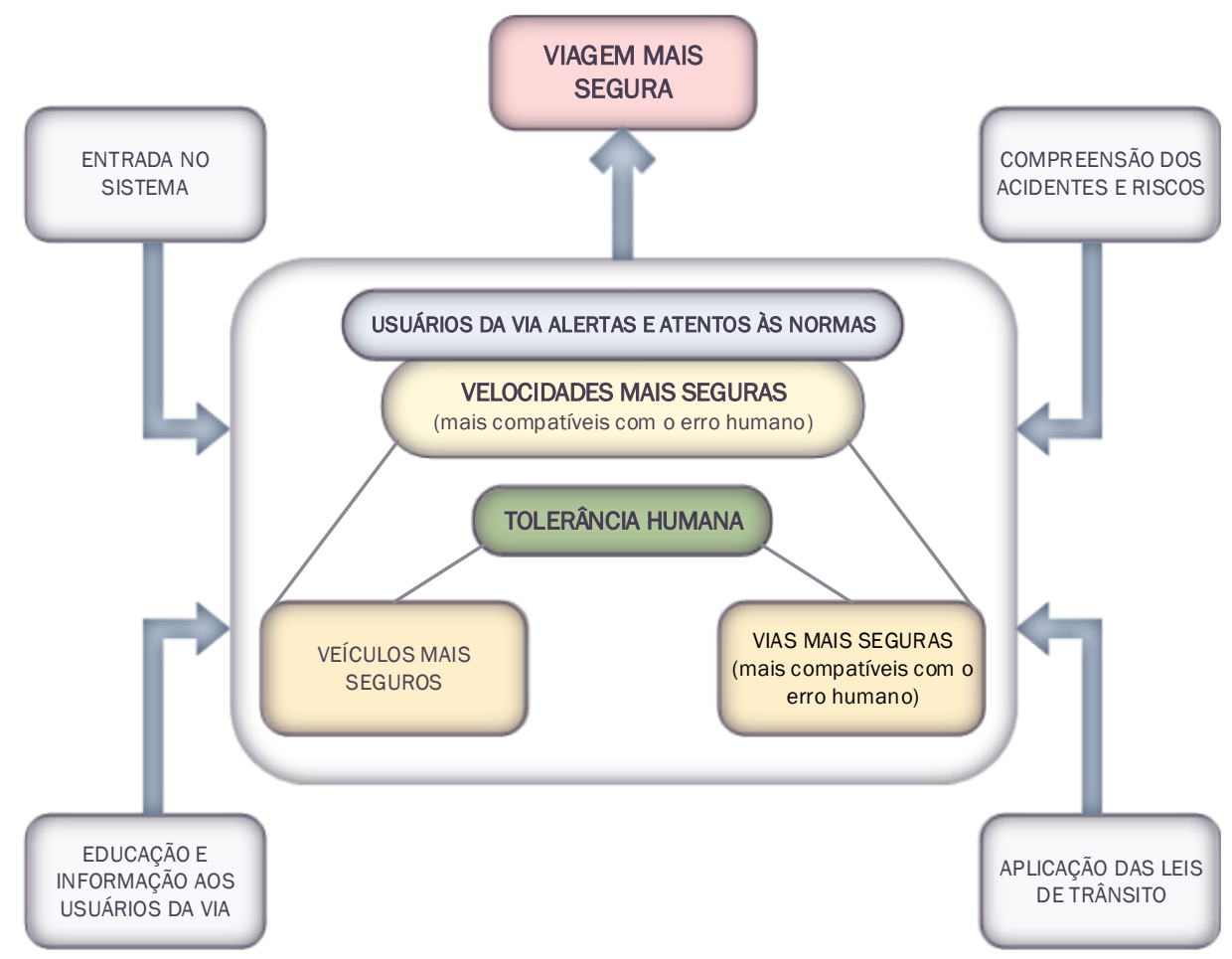

Figura 3.5 - A abordagem sistêmica de segurança.

Fonte: Adaptado de OPAS, 2013. 
O objetivo dessa abordagem é a eliminação de acidentes graves através do fornecimento de um sistema de transporte seguro, que é complacente com o erro humano e que leva em conta a vulnerabilidade das pessoas a ferimentos graves. Isso é feito através de políticas focadas na infraestrutura viária e na velocidade dos veículos, apoiada por uma série de atividades educativas, de mudança de comportamento, de regulamentação, fiscalização e penalidades.

Os princípios fundamentais da Abordagem Sistêmica de Segurança (OPAS, 2013) são: reconhecimento do erro humano no sistema de transportes; reconhecimento dos limites e da vulnerabilidade física humana; promoção da responsabilidade do sistema; promoção de valores éticos para segurança no trânsito e promoção de valores sociais. Além de garantir segurança, o sistema de transporte deve contribuir para os valores gerais da sociedade, particularmente em três áreas - desenvolvimento econômico, saúde ambiental e humana, e escolhas individuais.

\subsection{CONFORMIDAdE DE TRAVESSIA}

A análise do comportamento de pedestres pode ser realizada a partir da categorização das diferentes classes de usuários em função de seus padrões de comportamento, observando o uso do espaço e do tempo de travessia. Existem muitos fatores que afetam as decisões dos pedestres de atravessar em locais designados: a colocação adequada de faixa de pedestres em relação ao uso do solo - que pode gerar ou atrair o tráfego de pedestres, o design adequado da faixa de pedestres com base em padrões de engenharia existentes, a distribuição dos pedestres, a taxa de chegada de veículos, o tipo de controle do tráfego presente e a execução da travessia são alguns desses fatores. A literatura sugere que o processo que envolve a tarefa de atravessar uma via, caracteriza a conformidade de travessia (ROUPHAIL, 1984).

A conformidade de travessia representa a adequação ao uso das estruturas pelos pedestres, e pode ser analisada sob dois parâmetros: conformidade espacial e conformidade temporal. Para melhorar a mobilidade e a segurança dos pedestres, engenheiros de tráfego, planejadores e tomadores de decisão devem levar em consideração as preferências de travessia de pedestres e implementar projetos que sejam atraentes e aumentem a conformidade de travessia. Se a conformidade de travessia é baixa, podem ser necessárias medidas de educação, de engenharia ou de execução para garantir que a segurança dos pedestres não seja comprometida (SISIOPIKU e AKIN, 2000). 
O conceito de conformidade espacial de travessia está relacionado ao local em que o pedestre atravessa a via, e expressa a quantidade proporcional de pedestres que atravessam a via em local apropriado para a travessia em relação a todos os pedestres que fazem o cruzamento, em qualquer local. Com relação à conformidade espacial, os pedestres foram classificados por Sisiopiku e Akin (2003) em dois tipos: i) prudentes, aqueles que realizam a travessia na localização apropriada, ou seja, na área da travessia; e ii) imprudentes, aqueles que atravessam fora da área da travessia.

A conformidade temporal está relacionada ao momento em que o pedestre decide iniciar a travessia. Liu et al. (2000) consideraram conformidade temporal de travessia àquela dada em relação à indicação de luz verde para os pedestres no semáforo, considerando travessias semaforizadas. Na pesquisa citada, os pedestres foram classificados em duas categorias: i) obedientes, são pedestres que aguardam a indicação de luz verde no semáforo para iniciar a trajetória da travessia; e ii) oportunistas, que representam os pedestres que atravessam a via durante o sinal vermelho, se houver uma brecha disponível na corrente de tráfego de veículos.

Utilizando a classificação proposta por Liu et al. (2000) para a conformidade temporal em travessias semaforizadas, Yang et al. (2006) apresentaram um modelo do comportamento de pedestres para o sistema de micro simulação de tráfego na China. Foi observado que os pedestres oportunistas decidem violar o sinal de trânsito, durante o tempo em vermelho, dependendo de alguns fatores externos, como a ausência de policiais, a intensidade do fluxo de veículos e comportamentos dos outros pedestres, daí vem a denominação de "pedestre influenciado".

Ariotti (2006) desenvolveu um modelo conceitual, que propõe uma estrutura para compreensão das atitudes dos pedestres ao realizarem uma travessia, de acordo com o local e o momento escolhido. O objetivo do modelo foi analisar o padrão de comportamento de usuários, utilizando os conceitos de conformidade espacial e temporal, e identificar os fatores que influenciam as ações e percepções dos pedestres em relação às travessias semaforizadas na cidade de Porto Alegre, na região sul do Brasil. 
É importante ressaltar o fato de não ser conveniente considerar a conformidade temporal de travessia quando pedestres desobedecem a localização das travessias, realizando a trajetória de caminhada fora da área indicada. Assim, a conformidade espacial de travessia é a condição necessária para a conformidade temporal de travessia.

\subsection{TEORIAS COMPORTAMENTAIS}

A imensa multiplicidade de conquistas psicológicas que ocorrem ao longo da vida de cada indivíduo gera uma complexa configuração de processos de desenvolvimento que será absolutamente singular para cada sujeito. Em cada situação de interação com o mundo externo, o indivíduo encontra-se em um determinado momento de sua trajetória particular, trazendo consigo certas possibilidades de interpretação e de atribuição de novos significados aos resultados das interações que ocorrem com o ambiente externo (OLIVEIRA, 1997).

O comportamento de cada indivíduo é um produto da organização de diferentes práticas culturais e da construção compartilhada de sentidos e significados. O desenvolvimento individual se dá no interior de uma determinada situação histórico-cultural, que fornece aos sujeitos, e com eles constantemente reelabora, conteúdos culturais, artefatos materiais e simbólicos, interpretações, significados, modos de agir, de pensar, de sentir (OLIVEIRA, 2003). Assim, as características das várias fases de desenvolvimento das pessoas podem ser interpretadas de acordo com as visões de mundo e as formas de significação próprias de cada cultura.

Mas além do desenvolvimento histórico-cultural próprio de cada um, quando se tem a intenção de analisar algum tipo de comportamento, é necessário identificar como acontece a relação deste indivíduo com o espaço com que ele interage. Entende-se também que o indivíduo funciona não de maneira isolada, mas na presença, real ou imaginária, de outros, em uma situação que pode ser chamada de ambiente (ou cenário) social (GUNTHER, 2003). É necessário considerar o impacto das pessoas sobre o espaço e o do espaço sobre as pessoas, mas principalmente o processo de retroalimentação entre comportamento e a experiência das pessoas no espaço físico. 
As relações recíprocas pessoa - ambiente urbano acontecem no espaço físico mediante a mobilidade. Günther (2003) cita quatro conceitos do ambiente físico, salientes para o entendimento do comportamento humano ao interagir com o espaço:

i) Espaço pessoal, como sendo uma área com limites invisíveis cercando o corpo de uma pessoa na qual intrusos não são permitidos.

ii) Territorialidade como um conjunto de comportamentos e atitudes por parte de um indivíduo ou grupo, baseados em controle percebido, tentado ou real sobre um espaço físico definível, objeto ou ideia, que pode implicar em ocupação habitual, defesa, personalização e demarcação.

iii) Privacidade como controle seletivo do acesso a si mesmo ou a seu grupo.

iv) Apinhamento que se refere a um estado psicológico que inclui estresse e a motivação de sair de uma situação percebida subjetivamente como densa.

As dimensões físicas e psicológicas de espaço: pessoal, territorialidade, apinhamento e privacidade variam, antes de qualquer coisa, na medida em que as pessoas se deslocam de um lugar para outro. O movimento de uma pessoa, ou grupo de pessoas, afeta de maneira imediata e direta o seu espaço pessoal, a sua privacidade, o tamanho do seu território, a densidade e o apinhamento do espaço dentro do qual a pessoa se move. Essas variações podem exercer influência nas crenças pessoais (fator pessoal) e na intenção do pedestre em desempenhar determinado comportamento durante a travessia na faixa. Por isso se torna fundamental a identificação de como o pedestre realiza essa travessia na faixa, pois a partir desta identificação, pode ser possível determinar quais as crenças pessoais influenciam e são influenciadas por esse espaço físico, e qual o comportamento pode ser resultante da intenção que surge a partir dessas crenças.

O conhecimento das teorias baseadas em comportamento é necessário na construção conceitual que auxiliará a elaboração de diretrizes de investigação do comportamento das pessoas durante a travessia na faixa de pedestres. Esta pesquisa está fundamentada nos conceitos da Teoria do Comportamento Planejado (AJZEN, 1991), que constitui um aperfeiçoamento da Teoria da Ação Racional (AJZEN, 1985), e na representatividade do Comportamento Habitual (BAMBERG et al., 2003) na formação da intenção de comportamentos futuros. A seguir, são descritos os principais conceitos e abordagens presentes nos marcos teóricos supracitados. 


\subsubsection{A Teoria da Ação Racional}

Na busca do entendimento do comportamento humano, e não simplesmente na previsão deste, é necessária a identificação dos determinantes da intenção. De acordo com a Teoria da Ação Racional (AJZEN, 1985), a intenção de uma pessoa é uma função de dois determinantes básicos: a pessoa em seu pensamento natural e os reflexos da influência social. O fator pessoal significa a avaliação positiva ou negativa da realização de um comportamento.

É importante ressaltar que a teoria da ação racional está preocupada com atitudes relativas ao comportamento e não com atitudes mais tradicionais em relação a objetos, pessoas ou instituições. O segundo determinante da intenção é a percepção pessoal das pressões sociais que lhe são colocadas para executar ou não um comportamento em questão. Uma vez que lida com as prescrições percebidas, este fator é denominado norma subjetiva. De forma geral, as pessoas pretendem desempenhar um comportamento quando avaliam a positividade e quando acreditam na importância que outras pessoas darão a deste comportamento.

A teoria assume que a relativa importância desses fatores depende em parte da intenção investigada. Para algumas intenções, as considerações atitudinais (fator pessoal) podem ser mais importantes que as considerações normativas, enquanto para outras as considerações normativas podem predominar. Frequentemente, ambos os fatores são determinantes importantes da intenção. Além disso, os pesos relativos dos fatores atitudinais e normativos podem variar de uma pessoa para outra. A intenção é determinante do comportamento somente se a intenção não for modificada antes da realização do comportamento; e a intenção é assumida como sendo diretamente proporcional à somatória dos pesos da atitude em relação ao comportamento e das normas subjetivas.

A discussão sobre a Teoria da Ação Racional mostra como o comportamento intencional pode ser explicado em termos de um número limitado de conceitos. Através de uma série de processos intervenientes a teoria traça as causas do comportamento às crenças relevantes da pessoa. Cada passo sucessivo nessa sequência do comportamento para a crença fornece um relato mais compreensivo dos fatores determinantes do comportamento (Figura 3.6). 


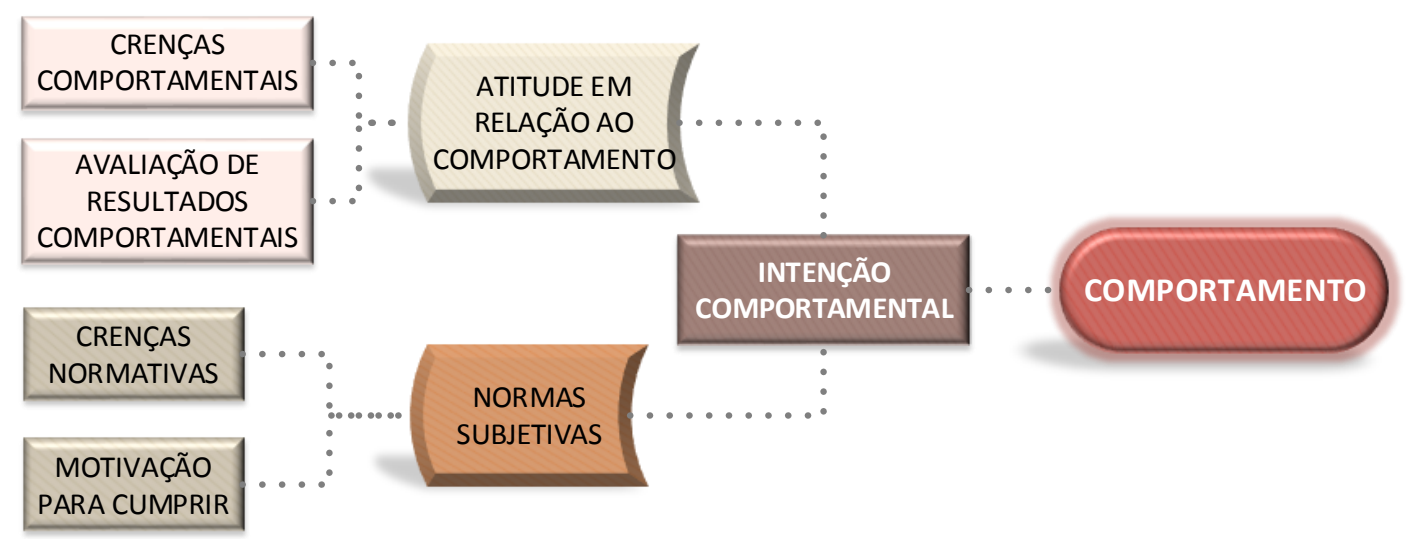

Figura 3.6 - Teoria da Ação Racional. Fonte: Adaptado de Ajzen (1985).

A atitude em relação ao comportamento é determinada pela avaliação pessoal das consequências associadas ao comportamento em questão e da força dessa associação. Especificamente, a avaliação de cada consequência contribui para a atitude em proporção à probabilidade subjetiva pessoal de que o comportamento produzirá o resultado em questão. Isto pode ser visto, de forma geral, em uma pessoa que acredita que um determinado comportamento a conduzirá a consequências positivas e irá adotar uma atitude favorável em relação ao desempenho deste comportamento, enquanto que uma pessoa que acredita que o comportamento a levará a uma consequência indesejável adotará uma atitude desfavorável.

As crenças que constituem a base de uma atitude pessoal em relação ao comportamento são denominadas crenças pessoais. As normas subjetivas também são consideradas uma função das crenças, mas crenças de diferente natureza, chamadas crenças pessoais que específicos grupos ou indivíduos pensam se alguém deve ou não realizar tal comportamento. Essas crenças subjacentes da norma subjetiva são chamadas de crenças normativas.

Outros fatores mais distantes, como características demográficas ou traços de personalidade, não exercem efeitos diretos no comportamento. De acordo com a teoria da ação racional, variáveis desse tipo estarão relacionadas ao comportamento se, e somente se, exercem influência nas crenças que delineiam os determinantes atitudinais ou normativos do comportamento. 


\subsubsection{Teoria do Comportamento Planejado - TCP}

A Teoria do Comportamento Planejado proposta por Ajzen (1991), elaborada a partir da Teoria da Ação Racional, considera que o comportamento social humano está fundamentado na natureza. A ação humana, segundo o autor, passa por três tipos de considerações:

i) as crenças pessoais, segundo as quais se avaliam as consequências prováveis de um comportamento, gerando uma atitude favorável ou desfavorável em relação a este comportamento;

ii) as crenças normativas, que representam a expectativa de terceiros sobre tal comportamento e assim constituem as normas subjetivas; e

iii) as crenças sobre fatores de controle, que podem favorecer ou prejudicar o desempenho do comportamento em questão, compondo a percepção de controle do comportamento.

As atitudes, normas subjetivas e as percepções de controle comportamental formarão a intenção do indivíduo em realizar um comportamento coerente com as suas crenças pessoais. As crenças pessoais e normativas são definidas ainda na Teoria da Ação Racional, já as crenças provenientes da percepção de controle comportamental, incluídas na Teoria do Comportamento Planejado (Figura 3.7), respondem aos tipos de fatores que podem facilitar ou dificultar o desempenho de um determinado comportamento. Assim sendo, quanto mais favorável a atitude e a norma subjetiva com respeito a um comportamento, e a uma maior percepção de controle comportamental, mais forte deve ser a intenção de uma pessoa para executar o comportamento considerado.

A importância relativa da atitude, norma subjetiva e percepção de controle comportamental na predição de intenção deverão variar entre comportamentos e situações. Desta forma, em algumas aplicações podem ser encontradas que apenas as atitudes têm um impacto significativo sobre as intenções, em outras em que as atitudes e controle comportamental percebido são suficientes para dar conta das intenções, e ainda em outros onde os três determinantes fazem contribuições independentes. 




Figura 3.7 - Modificação da Teoria da Ação Racional para a Teoria do Comportamento Planejado. Fonte: Adaptado de Ajzen (1991).

Um fator central na teoria do comportamento planejado é a intenção do indivíduo para executar um determinado comportamento. Intenções são assumidas para capturar os fatores motivacionais que influenciam o comportamento, são indicações a respeito das dificuldades que as pessoas estão dispostas a enfrentar, da dimensão de esforço planejado, a fim de realizar o comportamento. Como regra geral, quanto mais forte a intenção de iniciar uma conduta, mais provável deve ser o seu desempenho.

Deve ficar claro, no entanto, que uma intenção comportamental pode encontrar expressão no comportamento apenas se o comportamento em questão está em controle volitivo, isto é, se a pessoa pode decidir a vontade de realizar ou não realizar o comportamento (AJZEN, 1991). Embora alguns comportamentos possam, de fato, cumprir este requisito muito bem, o desempenho da maioria depende, pelo menos em algum grau, de fatores não motivacionais tais como a disponibilidade de oportunidades e os recursos necessários. Coletivamente, esses fatores representam o controle efetivo das pessoas sobre o comportamento. Na medida em que uma pessoa tem as oportunidades e os recursos necessários, e tem a intenção de realizar o comportamento, ela deve ter sucesso em fazer isso.

Em um nível inicial, o comportamento é supostamente determinado pela intenção. No próximo nível, essas intenções são por si próprias explicadas nos termos das atitudes relacionadas ao comportamento e das normas subjetivas. O terceiro nível explica essas atitudes e as normas 
subjetivas nos termos das crenças sobre as consequências da efetuação do comportamento a sobre as expectativas normativas de referências relevantes.

$\mathrm{Na}$ análise final, então, o comportamento de uma pessoa é explicado pelas referências ou fatores de influência das suas próprias crenças. Desde que as crenças das pessoas representem uma informação (que pode ser correta ou incorreta) que elas têm sobre seu mundo, isso resulta que os seus comportamentos são finalmente determinados por essa informação (Figura 3.8).

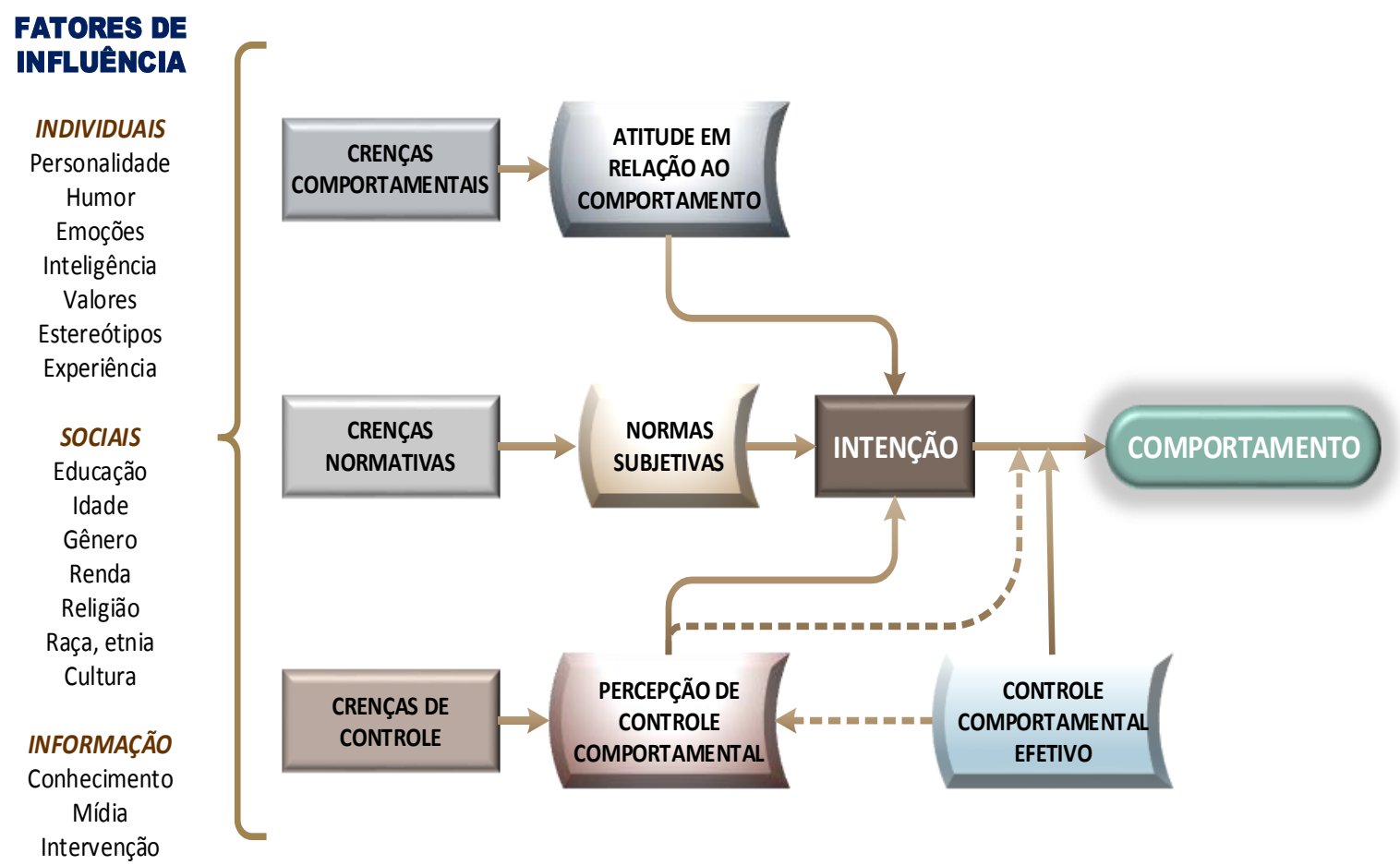

Figura 3.8 - Fatores que influenciam o Comportamento Planejado. Fonte: Adaptado de Ajzen (2011).

Como foi esquematizado na figura, percebe-se que para diferentes comportamentos, diferentes fatores de influência podem ser considerados, cabe ao pesquisador definir, através de uma pesquisa piloto, quais os principais fatores influenciam no comportamento estudado. Para tal, é necessária a definição do comportamento a ser investigado assim como a determinação de elementos táticos como a meta relacionada ao comportamento, a ação pretendida o contexto e o tempo de decisão.

A partir dessas definições, podem ser delineados os critérios comportamentais da amostra, como a listagem das crenças em relação a desempenhar e não desempenhar um determinado comportamento. Essas crenças podem ser identificadas com a utilização de efeitos antecipados 
(antecipated emocions) através de perguntas contraditórias como (i) sentimento de atravessar na faixa; (ii) sentimento de não atravessar na faixa. A tentativa de fazer as pessoas olharem para ambos os lados da questão pode proporcionar uma melhor avaliação do comportamento.

De acordo com a Teoria do Comportamento Planejado - TCP (AJZEN, 1991), o desempenho de um comportamento é uma função conjunta de intenções e percepção de controle comportamental. Para uma previsão de comportamento precisa, várias condições têm de ser cumpridas. Em primeiro lugar, as medidas da intenção e de percepção de controle comportamental devem corresponder ou ser compatível com o comportamento que será previsto. Isto é, as intenções e percepções de controle devem ser apreciadas em relação ao comportamento de interesse em particular, e o contexto especificado deve ser o mesmo em que aquele comportamento irá ocorrer. A segunda condição para a previsão de comportamento é que as intenções e percepção de controle comportamental devem permanecer estáveis no intervalo entre a sua avaliação e observação do comportamento. $\mathrm{O}$ terceiro requisito para validade preditiva tem a ver com a precisão do controle comportamental percebido.

A importância relativa das intenções e da percepção de controle comportamental na previsão de comportamento pode variar através das situações e através de comportamentos diferentes. Quando o comportamento ou situação proporciona um controle completo sobre o desempenho comportamental da pessoa, as intenções por si só deveriam ser suficientes para prever o comportamento, como especificado na Teoria da Ação Racional (AJZEN, 1985). A adição da percepção de controle comportamental deve tornar-se cada vez mais útil como controle volitivo sobre o comportamento. Ambos, intenções e percepções de controle do comportamento, podem contribuir significativamente para a previsão do comportamento, mas em qualquer aplicação, um pode ser mais importante do que o outro e, de fato, apenas um, dos dois indicadores podem ser necessários.

Alguns estudos aplicaram os construtos da TCP de Ajzen (1991) para a investigação do comportamento de pedestres em situações de travessia. Dentre esses estudos, tanto da área da psicologia (DÍAZ, 2002; EVANS e NORMAN, 1998; HOLLAND e HILL 2007) e da engenharia (ZHOU et al, 2009) quanto de ambas (BARRERO et al., 2013) utilizaram cenários, que buscaram retratar situações reais de travessia, para investigar a percepção de risco ao 
desempenhar um comportamento de não conformidade com regras de segurança para a travessia.

\subsubsection{Comportamento Habitual}

Bamberg et al. (2003) abordam uma contestação teórica do comportamento planejado considerando que o comportamento humano pode ser automático ou habitual, e desta forma deveria se considerar uma influência do comportamento passado na previsão do comportamento futuro. Os autores ressaltam que o comportamento humano não é completamente fundamentado, e acontece, pelo menos em parte, sob o controle direto da situação de estímulo.

A frequência de um comportamento passado é um indicador de força do hábito, e pode ser utilizada como forma de predição independente de uma ação posterior. Um comportamento torna-se habitual quando pouco esforço cognitivo é necessário para a execução contínua do movimento. Claramente, "hábito" é apenas um dos muitos fatores mediadores possíveis e, de fato, pode não ser totalmente necessário para ter em conta a estabilidade comportamental. Sob certas condições, é praticamente garantido que a frequência do comportamento passado será um poderoso preditor de comportamento futuro (BAMBERG et al., 2003). Uma medida do comportamento reflete mais a operação de todos os fatores internos e externos, do que o desempenho controlado (ou o não desempenho) do comportamento no passado.

O estudo apresentado por Bamberg et al. (2003) é uma tentativa de usar a TCP como base para um quadro conceitual de uma intervenção, objetivando efetuar uma mudança de comportamento. De acordo com a TCP, deveria ser possível influenciar as intenções e comportamentos através da concepção de uma intervenção que tem efeitos significativos sobre um ou mais dos fatores antecedentes, isto é, sobre as atitudes em relação ao comportamento, normas subjetivas e percepções de controle comportamental.

\subsection{Modelos Comportamentais Aplicados a Pedestres}

A necessidade de tornar as cidades mais "caminháveis", faz com que a compreensão sobre o comportamento do pedestre seja imprescindível. Pesquisas anteriores que investigaram o movimento de pedestres no ambiente urbano abordam uma variedade de temas que vão desde a modelagem de fluxo ao comportamento do pedestre na escolha de rotas e em travessias de 
vias. Este trabalho apresenta uma revisão literária de estudos existentes sobre o comportamento de pedestres em áreas urbanas, com foco no comportamento de travessia.

A revisão bibliográfica realizada mostra que o comportamento dos pedestres é influenciado por características demográficas como idade, sexo, entre outras, e características do ambiente de travessia, como velocidade dos veículos, número de faixas de tráfego, etc. Estes estudos foram desenvolvidos no contexto da engenharia e/ou da psicologia, e sugerem que as características individuais do pedestre, aliadas a fatores relacionados ao ambiente de travessia, podem ser determinantes do comportamento de travessia. O conhecimento das variáveis envolvidas nesse comportamento possibilita ao planejador de transportes a utilização da modelagem, que representa uma importante ferramenta na fase de planejamento, pois melhora a compreensão sobre o pedestre na medida em que permite estruturar e simular o comportamento deste durante o deslocamento.

O objetivo desse texto é apresentar uma revisão de pesquisas publicadas que investigaram o comportamento do pedestre em situação de travessia, abordando variáveis individuais e ambientais. Para tal, foi realizada uma revisão bibliográfica, envolvendo periódicos científicos, anais de congressos, pesquisas acadêmicas (teses e dissertações) e publicações de organizações governamentais relacionadas ao planejamento de mobilidade e transportes, através do uso de sistemas de busca literária.

Os resultados dessa revisão direcionam a novas questões a respeito dos aspectos conceituais e práticos da modelagem de pedestres, que poderão ser abordadas em pesquisas futuras. Se existem fortes indícios de que o comportamento dos pedestres é fruto de utilizações habituais somadas a decisões de planejamento (PAPADIMITRIOU et al., 2009), pode-se tentar conhecer e prever o comportamento do pedestre com o apoio de algumas teorias comportamentais, dentro dos contextos da engenharia e da psicologia.

Um modelo é, essencialmente, uma representação da realidade, uma abstração que se utiliza para alcançar uma maior clareza conceitual a cerca desta realidade, reduzindo a sua variedade e complexidade a níveis que permitam compreendê-la e especificá-la de forma adequada para a análise (ORTÚZAR, 2000). Normalmente, em um modelo se expressam, de forma 
simplificada, as características mais relevantes de um certo fenômeno ou situação real, para o caso estudado.

Uma variedade de fatores pessoais faz com que um indivíduo se comporte de maneira diferente de outro indivíduo. Estes diferentes fatores também permitem que os indivíduos tomem decisões pessoais quando se trata de seus comportamentos de viagem. O comportamento de viagem se refere ao que as pessoas fazem no espaço e a como elas se transportam. Nas pesquisas sobre comportamento de viagem é especialmente importante considerar os conceitos de alocação de tempo, características demográficas e características pessoais (BURBIDGE e GOULIAS, 2009).

Existem muitas características demográficas e pessoais que exercem influência reconhecida no comportamento de viagem, como idade, sexo, status econômico e nível educacional. No caso do comportamento de pedestres em travessias, os principais fatores demográficos investigados são idade, sexo, envolvimento prévio em acidentes e posse de licença para dirigir, sendo a idade a característica mais constante nas pesquisas (DIAZ, 2002; EVANS e NORMAN, 1998; HOLLAND e HILL, 2007; KADALI e VEDAGIRI, 2013; LIU e TUNG, 2014).

A maioria dos modelos de comportamento em travessia foi desenvolvido com o foco na tomada de decisão do pedestre em relação ao tempo e/ou local para realizar a travessia. Também parecem ser fortemente regulados pela teoria de aceitação de brechas, de acordo com a qual cada um dos pedestres escolhe uma brecha crítica para atravessar a via, ou pela teoria de utilidade, de acordo com a qual a utilidade de cada alternativa de travessia é um conceito latente, que é modelado como uma variável aleatória dependendo dos atributos da alternativa e as características do pedestre. Uma parte de estudos analisados examina diferentes aspectos do cruzamento de dados em vários locais e em diferentes condições, e baseia-se principalmente em modelos probabilísticos ou determinísticos comuns, calibrados por meio de dados observacionais.

Utilizando abordagem semelhante à apresentada por Papadimitriou et al. (2009), foi sintetizada na Tabela 3.1, a revisão bibliográfica das pesquisas sobre pedestres em situação de travessia, que investigaram e analisaram a influência de variáveis individuais e ambientais no comportamento observado ou relatado. Foram escolhidas apenas as pesquisas que consideraram 
variáveis individuais e ambientais e investigaram as suas relações no tratamento estatístico dos dados. Apesar de várias pesquisas brasileiras investigarem o comportamento de pedestres em momentos de travessia (ARIOTTI, 2006; CARVALHO, 2006; JACOBSEN, 2011; WERBERICH et al., 2012), não foram encontrados estudos que considerem as variáveis individuais dos pedestres, avaliando apenas aspectos do ambiente de travessia, por essa razão não foram consideradas na tabela. 
Tabela 3.1 - Revisão das pesquisas sobre comportamento de pedestres em travessias que investigaram variáveis individuais e ambientais.

\begin{tabular}{|c|c|c|c|c|c|c|c|}
\hline \multirow{2}{*}{$\begin{array}{l}\text { Ano } \\
\text { (País) }\end{array}$} & \multirow{2}{*}{$\begin{array}{c}\text { Autor } \\
\text { (Contexto) }\end{array}$} & \multirow{2}{*}{$\begin{array}{c}\text { Resumo do objetivo de } \\
\text { pesquisa }\end{array}$} & \multirow{2}{*}{$\begin{array}{c}\text { Base(s) teórica(s) do } \\
\text { instrumento de } \\
\text { pesquisa }\end{array}$} & \multicolumn{2}{|c|}{ Variáveis } & \multirow{2}{*}{$\begin{array}{l}\text { Coleta de } \\
\text { Dados } \\
\left(\mathbf{N}^{\circ}\right. \\
\text { amostra) } \\
\end{array}$} & \multirow{2}{*}{$\begin{array}{l}\text { Análise dos } \\
\text { dados }\end{array}$} \\
\hline & & & & Individuais & Ambientais & & \\
\hline $\begin{array}{c}1998 \\
\text { (País de } \\
\text { Gales) }\end{array}$ & $\begin{array}{l}\text { Evans e } \\
\text { Norman } \\
\text { (Psicologia) }\end{array}$ & $\begin{array}{l}\text { Examinar os determinantes da } \\
\text { intenção do pedestre ao fazer a } \\
\text { travessia em cenários que } \\
\text { representam situações de perigo } \\
\text { em potencial. }\end{array}$ & $\begin{array}{l}\text { Conceito de utilidade } \\
\text { e Teoria do } \\
\text { Comportamento } \\
\text { Planejado }\end{array}$ & $\begin{array}{l}\text { Idade, sexo e intenção de } \\
\text { comportamento }\end{array}$ & $\begin{array}{l}\text { Composição de } \\
\text { cenários retratando } \\
\text { situações de } \\
\text { travessia }\end{array}$ & $\begin{array}{l}\text { Questionário } \\
\text { Autorrelato } \\
\quad(210)\end{array}$ & $\begin{array}{l}\text { Regressão } \\
\text { Hierárquica }\end{array}$ \\
\hline $\begin{array}{c}2001 \\
\text { (Jordânia) }\end{array}$ & $\begin{array}{l}\text { Hamed } \\
\text { (Engenharia) }\end{array}$ & $\begin{array}{l}\text { Introduzir uma metodologia, } \\
\text { combinando modelos de } \\
\text { duração e contagem, para } \\
\text { estudar o comportamento de } \\
\text { pedestres em travessias } \\
\text { localizadas em vias com e sem } \\
\text { refúgio central. }\end{array}$ & $\begin{array}{l}\text { Aceitação de brechas, } \\
\text { teoria de análise de } \\
\text { sobrevivência }\end{array}$ & $\begin{array}{l}\text { Idade, sexo, estado civil, } \\
\text { n. }{ }^{\circ} \text { de crianças, } \\
\text { disponibilidade de veículo } \\
\text { particular, local de } \\
\text { moradia e envolvimento } \\
\text { prévio em acidentes }\end{array}$ & $\begin{array}{l}\text { Travessias de vias } \\
\text { com e sem refúgio } \\
\text { central }\end{array}$ & $\begin{array}{l}\text { Entrevista } \\
\quad(350 \\
\text { pedestres })\end{array}$ & $\begin{array}{l}\text { Modelos de } \\
\text { riscos } \\
\text { proporcionais } \\
\text { e Regressão de } \\
\text { Poisson }\end{array}$ \\
\hline $\begin{array}{c}2002 \\
\text { (Chile) }\end{array}$ & $\begin{array}{l}\text { Díaz } \\
\text { (Psicologia) }\end{array}$ & $\begin{array}{l}\text { Mensurar as atitudes dos } \\
\text { pedestres em relação a violações } \\
\text { das regras de trânsito, auto } \\
\text { avaliação de violações, erros e } \\
\text { lapsos. }\end{array}$ & $\begin{array}{l}\text { Percepção de risco e } \\
\text { Teoria do } \\
\text { Comportamento } \\
\text { Planejado }\end{array}$ & $\begin{array}{l}\text { Idade, sexo, envolvimento } \\
\text { prévio em acidentes e } \\
\text { posse de licença para } \\
\text { dirigir }\end{array}$ & $\begin{array}{l}\text { Composição de } \\
\text { cenários retratando } \\
\text { situações de } \\
\text { travessia }\end{array}$ & $\begin{array}{l}\text { Questionário } \\
\text { Autorrelato } \\
\text { (146) }\end{array}$ & $\begin{array}{l}\text { Modelagem } \\
\text { por equação } \\
\text { estrutural }\end{array}$ \\
\hline $\begin{array}{c}2004 \\
\text { (Israel) }\end{array}$ & $\begin{array}{l}\text { Rosenbloom } \\
\text { et al. } \\
\text { (Psicologia) }\end{array}$ & $\begin{array}{l}\text { Investigar os efeitos da } \\
\text { religiosidade e da fé no } \\
\text { comportamento dos pedestres. }\end{array}$ & Percepção de risco & Idade e sexo & $\begin{array}{l}\text { Localização: região } \\
\text { ultra ortodoxa e } \\
\text { região não ortodoxa }\end{array}$ & $\begin{array}{l}\text { Observação } \\
\text { (1047) }\end{array}$ & Qui quadrado \\
\hline $\begin{array}{c}2004 \\
\text { (Japão) }\end{array}$ & $\begin{array}{l}\text { Muraleetharan } \\
\text { et al. } \\
\text { (Engenharia e } \\
\text { psicologia) }\end{array}$ & $\begin{array}{l}\text { Propor um método para } \\
\text { determinar o nível de serviço de } \\
\text { um caminho para pedestres, } \\
\text { considerando as condições de } \\
\text { calçadas e travessias. }\end{array}$ & $\begin{array}{l}\text { Nível de serviço e } \\
\text { conceito de utilidade }\end{array}$ & $\begin{array}{l}\text { Idade, sexo, ocupação, } \\
\text { modo de viagem }\end{array}$ & $\begin{array}{l}\text { Infraestrutura } \\
\text { viária, tráfego e } \\
\text { facilidades de } \\
\text { travessia }\end{array}$ & $\begin{array}{c}\text { Questionário } \\
\text { Autorrelato } \\
\text { (531) }\end{array}$ & $\begin{array}{l}\text { Equação de } \\
\text { utilidade } \\
\text { proposta como } \\
\text { método }\end{array}$ \\
\hline $\begin{array}{c}2007 \\
\text { (Inglaterra) }\end{array}$ & $\begin{array}{l}\text { Holland e Hill } \\
\text { (Psicologia) }\end{array}$ & $\begin{array}{l}\text { Examinar as diferenças de } \\
\text { crenças entre os grupos } \\
\text { demográficos na intenção de } \\
\text { fazer a travessia em situação de } \\
\text { risco. }\end{array}$ & $\begin{array}{l}\text { Percepção de risco e } \\
\text { Teoria do } \\
\text { Comportamento } \\
\text { Planejado }\end{array}$ & $\begin{array}{l}\text { Idade, sexo, motoristas e } \\
\text { não motoristas }\end{array}$ & $\begin{array}{l}\text { Composição de } \\
\text { cenários retratando } \\
\text { situações de } \\
\text { travessia }\end{array}$ & $\begin{array}{c}\text { Questionário } \\
\text { Autorrelato } \\
\text { (293) }\end{array}$ & $\begin{array}{l}\text { Modelo linear } \\
\text { generalizado }\end{array}$ \\
\hline
\end{tabular}


Tabela 3.1 (continuação) - Revisão das pesquisas sobre comportamento de pedestres em travessias que investigaram variáveis individuais e ambientais.

\begin{tabular}{|c|c|c|c|c|c|c|c|}
\hline \multirow{2}{*}{$\begin{array}{l}\text { Ano } \\
\text { (País) }\end{array}$} & \multirow{2}{*}{$\begin{array}{c}\text { Autor } \\
\text { (Contexto) }\end{array}$} & \multirow{2}{*}{$\begin{array}{l}\text { Resumo do objetivo de } \\
\text { pesquisa }\end{array}$} & \multirow{2}{*}{$\begin{array}{l}\text { Base(s) teórica(s) do } \\
\text { instrumento de } \\
\text { pesquisa }\end{array}$} & \multicolumn{2}{|c|}{ Variáveis } & \multirow{2}{*}{$\begin{array}{c}\text { Dados } \\
\left(\mathbf{N}^{\circ}\right. \\
\text { amostra })\end{array}$} & \multirow{2}{*}{$\begin{array}{l}\text { Análise dos } \\
\text { dados }\end{array}$} \\
\hline & & & & Individuais & Ambientais & & \\
\hline $\begin{array}{c}2009 \\
\text { (China) }\end{array}$ & $\begin{array}{l}\text { Zhou et al. } \\
\text { (Engenharia) }\end{array}$ & $\begin{array}{l}\text { Examinar o papel da } \\
\text { conformidade de travessia em } \\
\text { relação ao comportamento de } \\
\text { outros pedestres }\end{array}$ & $\begin{array}{l}\text { Percepção de risco e } \\
\text { Teoria do } \\
\text { Comportamento } \\
\text { Planejado }\end{array}$ & $\begin{array}{l}\text { Idade, sexo e tendências de } \\
\text { conformidade }\end{array}$ & $\begin{array}{l}\text { Composição de } \\
\text { cenários retratando } \\
\text { situações de travessia }\end{array}$ & $\begin{array}{l}\text { Questionário } \\
\text { Autorrelato } \\
\text { (426) }\end{array}$ & $\begin{array}{l}\text { Regressão } \\
\text { linear } \\
\text { múltipla }\end{array}$ \\
\hline $\begin{array}{c}2011 \\
\text { (França) }\end{array}$ & $\begin{array}{l}\text { Tom e Grainé } \\
\text { (Engenharia) }\end{array}$ & $\begin{array}{l}\text { Explorar as diferenças entre } \\
\text { gêneros na conformidade com } \\
\text { as regras de travessia para } \\
\text { pedestres. }\end{array}$ & $\begin{array}{l}\text { Conformidade de } \\
\text { travessia }\end{array}$ & $\begin{array}{l}\text { Sexo, movimento de } \\
\text { cabeça em direção a } \\
\text { veículos, outros pedestres, } \\
\text { chão e semáforos }\end{array}$ & $\begin{array}{l}\text { Travessias } \\
\text { semaforizadas e não } \\
\text { semaforizadas }\end{array}$ & $\begin{array}{l}\text { Observações } \\
(400)\end{array}$ & $\begin{array}{l}\text { Qui } \\
\text { quadrado }\end{array}$ \\
\hline $\begin{array}{c}2013 \\
\text { (Colômbia) }\end{array}$ & $\begin{array}{l}\text { Barrero } \\
\text { et al. } \\
\text { (Engenharia e } \\
\text { psicologia) } \\
\end{array}$ & $\begin{array}{l}\text { Desenvolver um instrumento } \\
\text { de autorrelato para investigar } \\
\text { o comportamento de pedestres } \\
\text { em relação à travessia de vias }\end{array}$ & $\begin{array}{l}\text { Percepção de risco e } \\
\text { Teoria do } \\
\text { Comportamento } \\
\text { Planejado } \\
\end{array}$ & $\begin{array}{l}\text { Idade, sexo, escolaridade, } \\
\text { situação de trabalho }\end{array}$ & $\begin{array}{l}\text { Composição de } \\
\text { cenários retratando } \\
\text { situações de travessia }\end{array}$ & $\begin{array}{l}\text { Questionário } \\
\text { autorrelato e } \\
\text { observações } \\
\text { (20) } \\
\end{array}$ & $\begin{array}{l}\text { Análise } \\
\text { Fatorial }\end{array}$ \\
\hline $\begin{array}{c}2012 \\
\text { (Grécia) }\end{array}$ & $\begin{array}{l}\text { Papadimitriou } \\
\text { (Engenharia e } \\
\text { psicologia) }\end{array}$ & $\begin{array}{l}\text { Analisar o comportamento de } \\
\text { pedestres em relação à } \\
\text { travessia ao longo de viagens } \\
\text { inteiras em malhas viárias } \\
\text { urbanas. }\end{array}$ & $\begin{array}{l}\text { Consideração } \\
\text { topológica das redes } \\
\text { viárias e calçadas } \\
\text { urbanas e teoria de } \\
\text { utilidade estocástica } \\
\end{array}$ & $\begin{array}{l}\text { Idade, sexo, velocidade de } \\
\text { caminhada, pressa, posse } \\
\text { de bagagens, acompanhado } \\
\text { por outra pessoa }\end{array}$ & $\begin{array}{l}\text { Cenário real de } \\
\text { caminhada } \\
\text { proporcionando } \\
\text { escolhas de travessia }\end{array}$ & $\begin{array}{l}\text { Filmagens } \\
\quad(491)\end{array}$ & $\begin{array}{l}\text { Modelos de } \\
\text { escolha } \\
\text { discreta }\end{array}$ \\
\hline $\begin{array}{c}2013 \\
(19 \text { países } \\
\text { da Europa) }\end{array}$ & $\begin{array}{l}\text { Papadimitriou } \\
\text { et al. } \\
\text { (Engenharia e } \\
\text { psicologia) } \\
\end{array}$ & $\begin{array}{l}\text { Identificar padrões de atitudes, } \\
\text { percepção e comportamento } \\
\text { dos pedestres na Europa. }\end{array}$ & $\begin{array}{l}\text { Percepção de risco e } \\
\text { regras de segurança } \\
\text { viária. }\end{array}$ & Sexo, idade, nacionalidade & $\begin{array}{l}\text { Área rural, suburbana, } \\
\text { urbana }\end{array}$ & $\begin{array}{c}\text { SARTRE } 4 \\
\text { Questionário } \\
\text { (4290) }\end{array}$ & $\begin{array}{l}\text { Análise de } \\
\text { cluster }\end{array}$ \\
\hline $\begin{array}{c}2013 \\
\text { (Índia) }\end{array}$ & $\begin{array}{l}\text { Kadali e } \\
\text { Vedagiri } \\
\text { (Engenharia) }\end{array}$ & $\begin{array}{l}\text { Investigar o comportamento } \\
\text { sob condições de tráfego } \\
\text { misto, considerando brechas } \\
\text { defasadas. }\end{array}$ & $\begin{array}{l}\text { Aceitação de brechas } \\
\text { e teoria da escolha } \\
\text { discreta }\end{array}$ & $\begin{array}{l}\text { Sexo, idade, posse de } \\
\text { bagagens, padrão de } \\
\text { travessia }\end{array}$ & $\begin{array}{l}\text { Tempo de espera e de } \\
\text { observação do fluxo, } \\
\text { pelotão de pedestres, } \\
\text { velocidade dos } \\
\text { veículos e pedestres } \\
\end{array}$ & $\begin{array}{l}\text { Filmagens } \\
(4198 \\
\text { brechas })\end{array}$ & $\begin{array}{l}\text { Regressão } \\
\text { linear } \\
\text { múltipla }\end{array}$ \\
\hline $\begin{array}{c}2014 \\
\text { (Taiwan) }\end{array}$ & $\begin{array}{l}\text { Liu e Tung } \\
\text { (Engenharia) }\end{array}$ & $\begin{array}{l}\text { Investigar os efeitos da idade, } \\
\text { brecha, hora do dia e } \\
\text { velocidade de aproximação do } \\
\text { veículo na decisão de } \\
\text { atravessar a via. }\end{array}$ & Aceitação de brechas & $\begin{array}{l}\text { Idade, velocidade de } \\
\text { marcha }\end{array}$ & $\begin{array}{l}\text { Hora do dia, brecha } \\
\text { admissível, velocidade } \\
\text { do veículo }\end{array}$ & $\begin{array}{l}\text { Observação } \\
\text { e entrevista } \\
\text { (32) }\end{array}$ & $\begin{array}{l}\text { Regressão } \\
\text { Logística }\end{array}$ \\
\hline
\end{tabular}




\subsection{CONSIDERAÇÕES SOBRE O CAPÍTULO}

O presente capítulo revisou as teorias utilizadas para compreender o comportamento humano no trânsito, envolvendo o comportamento de pedestres e motoristas, e os modelos utilizados para representar os comportamentos de pedestres em situação de travessia. As principais teorias da psicologia utilizadas em estudos relacionados ao trânsito fazem associações entre questões relativas ao comportamento e outros fatores, psíquicos, sociais, ambientais, habituais.

Ajzen (1991) considera que a maioria dos comportamentos humanos é fundamentada. Bamberg, Ajzen e Schmidt (2003) sugerem que o comportamento humano pode também ser automático ou habitual, e desta forma pode se considerar uma influência do comportamento passado na previsão do comportamento futuro. Na verdade, o comportamento humano não é completamente fundamentado, e acontece, pelo menos em parte, sob o controle direto da situação de estímulo, que pode ser ambiental, cultural, social, etc. A frequência de um comportamento passado é um indicador de força do hábito, e pode ser utilizada como forma de predição independente de uma ação posterior. Um comportamento torna-se habitual quando pouco esforço cognitivo é necessário para a execução contínua do movimento (BAMBERG, AJZEN e SCHMIDT, 2003).

A literatura sugere que o comportamento adotado pelos pedestres, no processo que envolve a tarefa de atravessar uma via, caracteriza a conformidade de travessia (ROUPHAIL, 1984). A conformidade de travessia representa a adequação espacial e temporal no uso da estrutura de travessia pelos pedestres. A análise do comportamento de pedestres pode ser realizada a partir da categorização das diferentes classes de usuários em função de seus padrões de comportamento. Sisiopiku e Akin (2003) sugerem a classificação dos pedestres em relação à conformidade de travessia espacial. Liu et al. (2000), na descrição do modelo de simulação de movimentos de pedestres e veículos, classificam os pedestres de acordo com o conceito de conformidade de travessia temporal.

O comportamento humano, de acordo com a Teoria do Comportamento Planejado - TCP, é guiado por três tipos de considerações: crenças sobre as consequências prováveis do 
comportamento (crenças comportamentais), crenças sobre as expectativas normativas de outros (crenças normativas), e crenças sobre a presença de fatores que podem facilitar ou impedir o desempenho do comportamento (crenças de controle). Em seus respectivos agregados, crenças comportamentais produzem uma atitude favorável ou desfavorável para o comportamento; crenças normativas resultam em pressão social percebida ou norma subjetiva; e as crenças de controle dão origem à percepção de controle comportamental.

Em combinação, a atitude em relação ao comportamento, a norma subjetiva, e a percepção de controle comportamental contribuem para a formação de uma intenção comportamental. Como regra geral, quanto mais favorável a atitude e a norma subjetiva, e quanto maior for o controle percebido, mais forte deve ser a intenção da pessoa para executar o comportamento em questão. No entanto, devido ao fato de muitos comportamentos apresentarem dificuldades de execução, que podem limitar o controle volitivo, é útil considerar o controle comportamental percebido, além da intenção (AJZEN, 1991). Na medida em que a percepção de controle comportamental é verídica, ela pode servir como um substituto para o controle efetivo e contribuir para a previsão do comportamento em questão.

Os estudos que utilizaram a TCP para investigar o comportamento do pedestre durante a travessia, em sua maioria focaram a investigação de percepção de risco durante a travessia, através de questionários abordando a opinião do respondente em relação a situações de travessia ilustradas por um cenário fictício. Essas pesquisas se mostraram eficientes em relacionar os construtos da TCP com o risco percebido durante a travessia. Identifica-se, entretanto, na revisão bibliográfica a existência de uma lacuna, no que se refere ao desenvolvimento de estudos que investiguem o comportamento habitual do pedestre durante a travessia, sem a inclusão de riscos ou percepção deste, abordando questões relacionadas com a conformidade de travessia em conjunto com construtos das teorias comportamentais, e variáveis individuais e ambientais. 


\section{MÉTODO}

... as pessoas possuem motivação para serem aceitas pelos outros - todos queremos ser apreciados, incluídos, fazer parte de alguma coisa. Sabemos que quando não nos conformamos com a maioria, isso pode envolver "sanções" sociais. Para evitar essas consequências negativas de ser o "estranho no ninho", as pessoas se motivam a seguir a norma grupal.

Richard J. Crisp e Rhiannon N. Turner (2013)

A revisão literária apresentada buscou definir e caracterizar o pedestre, a infraestrutura oferecida para o seu deslocamento e interação deste com o ambiente de circulação. As teorias comportamentais descritas propõem a investigação de um comportamento a partir dos fatores que o determinam. Os conceitos e teorias descritos nos capítulos 2 e 3, embasaram a elaboração de um método de indicação do perfil do pedestre, que é detalhado neste capítulo, para permitir o conhecimento do comportamento do pedestre, durante a travessia em faixas não semaforizadas.

O método, que doravante será identificado pela sigla MIPP (Método de Indicação do Perfil do Pedestre) para evitar repetições desnecessárias, pretende conhecer o perfil dos pedestres em ambientes de convivência diária, como nos locais de trabalho e estudo (campus universitário, escolas, prédios de escritórios, departamentos públicos etc.) que reúnam um grande número de pessoas. Acredita-se que as normas subjetivas ou sociais exerçam grande influência no comportamento das pessoas durante a travessia na faixa de pedestres. $O$ conhecimento do perfil dos pedestres, relacionado com as características do comportamento das pessoas que frequentam a localidade pesquisada, pode auxiliar a tomada de decisões em relação ao planejamento da circulação dos pedestres no local, além de poder melhor direcionar as intervenções no ambiente de travessia.

\subsection{APRESEntaÇão}

O método proposto visa coletar dados indicadores do comportamento dos pedestres durante a travessia e a identificação das variáveis que influenciam esse comportamento, considerando a forma de utilização da faixa de pedestre durante a travessia. Mas, de forma distinta dos estudos comportamentais, citados na revisão literária apresentada no capítulo 2 , 
o MIPP pretende identificar as características predominantes do perfil do pedestre que realiza a travessia de forma "correta" considerando: a assertividade em iniciar a travessia, a velocidade de caminhada e a atenção ao fluxo de veículos durante a travessia.

Para tal identificação, foram definidos construtos específicos, baseados na literatura correlata ao tema e nas observações do comportamento em travessias. Esses construtos foram utilizados na elaboração de um questionário, que permite ao respondente indicar o seu comportamento de travessia em faixa de pedestre não semaforizada. A necessidade de propor novos construtos para a investigação do comportamento do pedestre durante a travessia deriva do fato de não estar disponível na literatura um instrumento voltado para o conhecimento desse comportamento. As investigações que abordam o comportamento dos pedestres em travessia geralmente se atêm a pesquisar as percepções e exposições a fatores de risco.

A proposta metodológica se constitui em testar a validade deste questionário, que inicia investigando o perfil do respondente como pedestre, a partir da forma de utilização da faixa para a travessia, através de uma sequência de comportamentos descritos, onde o participante escolhe aquele comportamento com o qual mais se identifica. Posteriormente a pesquisa propõe questões relativas à intenção de atravessar na faixa, ao histórico e preferências de utilização da faixa, aos hábitos de transporte, características individuais, escolaridade e ocupação. As duas primeiras etapas de elaboração do método constituem a base investigativa que sustentará a formulação das questões incluídas no questionário da terceira etapa. Para o desenvolvimento das três etapas iniciais foram necessários estudos de observação e coleta de dados sobre o comportamento dos pedestres. A quarta e última etapa do método é o produto final pretendido pelo estudo: um instrumento que possa indicar o perfil do comportamento dos pedestres de uma localidade. A Figura 4.1 que apresenta a estrutura do MIPP, mostra que ele é dividido em quatro etapas, com a finalidade de identificar, em sua última etapa, qual o perfil dominante do pedestre na região estudada. 


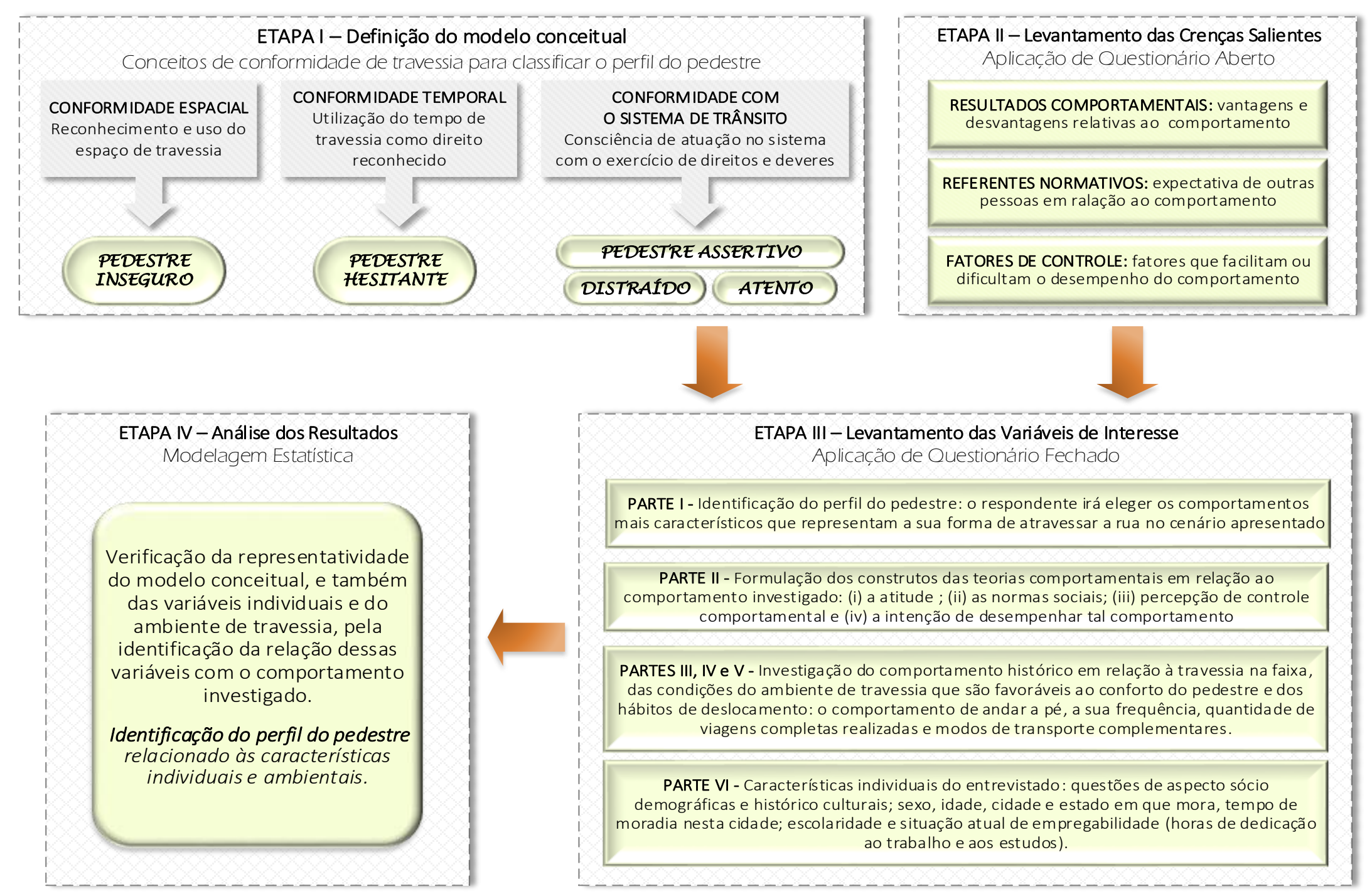

Figura 4.1 - Estrutura do método para identificar o comportamento do pedestre durante a travessia em faixas sinalizadas e não semaforizadas. 


\subsection{ETAPa I - Definição do Modelo Conceitual}

Neste item serão introduzidos e discutidos alguns conceitos e premissas essenciais para a estruturação e entendimento do MIPP. Esta primeira etapa define o modelo conceitual do comportamento de pedestres durante a travessia na faixa. As diretrizes de observação do comportamento dos pedestres, para a estruturação do método, foram definidas a partir das instruções contidas no Artigo 69 do Código de Trânsito Brasileiro (CTB, 1997): "Para cruzar a pista de rolamento o pedestre tomará precauções de segurança, levando em conta, principalmente, a visibilidade, a distância e a velocidade dos veículos, utilizando sempre as faixas ou passagens a ele destinadas sempre que estas existirem numa distância de até cinquenta metros dele".

Assim, na elaboração do método foi considerado como precaução de segurança, levando em conta a visibilidade, o fato do pedestre acenar ao iniciar a travessia indicando aos motoristas o seu desejo de realizar a travessia e reforçando a possibilidade de o pedestre aumentar a sua visibilidade. Sobre levar em conta a distância e velocidade dos veículos, Liu e Tung (2014) concluíram, através de entrevistas e observações, que os pedestres não são sensíveis nem perceptivos visualmente à variação de velocidade dos veículos, e que as decisões de travessia são, na sua maioria, tomadas em relação à distância dos veículos.

\subsubsection{Conformidade de travessia em faixas não semaforizadas}

Um conceito fundamental para a construção do modelo conceitual que, na primeira etapa do MIPP define as caraterísticas dos perfis de comportamento dos pedestres, é o conceito de conformidade de travessia proposto por Rouphail (1984), descrito no item 2.2.2. A conformidade de travessia, segundo o autor, representa a adequação ao uso das estruturas pelos pedestres, e pode ser analisada sob dois parâmetros: conformidade espacial e conformidade temporal. Os dois parâmetros de conformidade foram citados por alguns autores (ARIOTTI, 2006; LIU et al., 2000; SISIOPIKU e AKIN, 2000, 2003, 2007; YANG et al., 2006) em artigos que investigaram o comportamento de pedestres em faixas de travessia semaforizadas. 
Na composição do MIPP, esses parâmetros de conformidade foram abordados com algumas adaptações necessárias, para a investigação do comportamento dos pedestres na faixa não semaforizada. Optou-se por utilizar critérios de verificação do uso do espaço e do tempo de travessia, além dos critérios de precauções de segurança, representados pelo comportamento no início e durante a travessia.

No conceito de conformidade de travessia aqui utilizado, também foi introduzido um novo parâmetro, de conformidade com o sistema de trânsito, segundo a abordagem sistêmica de segurança proposta pela OPAS (2013) apresentado no item 3.1 e esquematizado na figura 3.5. Esse novo parâmetro introduzido investiga se o pedestre se reconhece como parte atuante nesse sistema de trânsito, identificando seus direitos e deveres durante a travessia. Pretende-se, com as adaptações dos dois parâmetros do conceito inicial de conformidade de travessia de Rouphail (1984) e com a introdução do novo parâmetro de conformidade com o sistema de trânsito, conseguir identificar a conformidade de travessia ajustada à utilização da faixa de pedestre não semaforizada. A seguir são detalhadas as adaptações e inserções no conceito de conformidade de travessia.

\subsubsection{Conformidade espacial}

A conformidade espacial está relacionada ao local que o pedestre utiliza para realizar a travessia. O pedestre está em conformidade espacial quando utiliza o local certo, delimitado por um espaço, para realizar a travessia. O MIPP considera somente as travessias realizadas no espaço delimitado pela pintura da faixa de pedestre no pavimento. $\mathrm{O}$ foco investigativo é o comportamento dos pedestres considerados “prudentes", segundo a denominação utilizada por Sisiopiku e Akin (2003), ou seja, aqueles que fazem a travessia no local marcado pela pintura da faixa de pedestres.

Na proposta do método, o conceito de conformidade espacial é abordado de uma forma diferente das abordagens encontradas na literatura (ARIOTTI, 2006; ROUPHAIL, 1984; SISIOPIKU e AKIN, 2000, 2003, 2007), que consideraram uma área nas proximidades da faixa, onde são observadas se as travessias ocorrem dentro ou fora desta área. O conceito de conformidade espacial, no MIPP, busca identificar se o pedestre reconhece o espaço delimitado pela pintura da faixa como o espaço reservado para sua travessia e se exerce o seu direito de uso desse espaço. 
O instante inicial de travessia mostra a relação do pedestre com a faixa através do comportamento de aproximação desse espaço para fazer a travessia. Como já foi explicitado, o MIPP se aplica à situação de travessia na faixa de pedestres e, desta forma, a conformidade de área, conforme a literatura citada utiliza, já estaria satisfeita. O que o método busca identificar é se o pedestre tem consciência da utilização daquele espaço e da sua prioridade de travessia quando escolhe atravessar na faixa e não em outro local. Para tal, são analisadas duas formas de comportamento do pedestre ao iniciar a travessia: i) o pedestre espera surgir uma brecha entre o fluxo de veículos para iniciar a travessia; ii) o pedestre sinaliza com a mão, indicando aos motoristas que deseja fazer a travessia, com a intenção de interromper o fluxo dos veículos.

Analisando a primeira hipótese de comportamento: o pedestre se aproxima da faixa para fazer a travessia, mas não manifesta a intenção de interromper o fluxo de veículos. Esse comportamento pode sugerir que o pedestre reconhece o seu espaço de travessia, mas não tem a segurança de que os carros irão lhe dar passagem. Assim ele espera um momento oportuno, como uma brecha no fluxo de veículos, para fazer a travessia com maior segurança. Por outro lado, se o pedestre se coloca em frente à faixa e sinaliza com a mão para tentar interromper o fluxo de veículos - segunda hipótese de comportamento - ele não só reconhece aquele espaço como seu espaço de travessia, como também exerce o direito de uso desse espaço, lembrando ao motorista da sua prioridade na travessia. O pedestre que apresenta esse comportamento está em conformidade espacial na faixa não semaforizada. Após essa confirmação, o próximo passo é analisar a situação de conformidade temporal.

Vale salientar aqui que a sinalização antes de iniciar a travessia, gesto em que o pedestre estende o braço indicando para os condutores que deseja fazer a travessia, denominado de "sinal de vida" por campanhas publicitárias que incentivam o uso da faixa, ainda não é regulamentado pelo Código de Transito Brasileiro - CTB. Existe um Projeto de Lei da Câmara Federal (n 26, de 2010), ainda em tramitação, cuja ementa propõe a alteração do artigo 69 e o item 6 do Anexo I - Sinalização, da Lei no 9.503, de 27 de setembro de 1997, que institui o CTB, para dispor sobre a travessia de pedestres em passagem sinalizada. A explicação de ementa é "inclusão, no Código de Trânsito Brasileiro, como medida de precaução de segurança, do "gesto do pedestre" a ser feito com o braço, indicando que vai 
cruzar a pista de rolamento ("sinal de vida")". Um resumo da tramitação desse projeto de lei é apresentado no Anexo I.

\subsubsection{Conformidade temporal}

A conformidade temporal busca identificar se o pedestre realiza a travessia utilizando o tempo reservado para que essa travessia aconteça. As pesquisas que utilizaram esse conceito (ARIOTTI, 2006; LIU et al., 2000; YANG et al., 2006) investigaram travessias semaforizadas, onde a conformidade temporal acontece quando o pedestre faz a travessia no tempo de verde indicado pelo semáforo.

Como a aplicação do MIPP pressupõe a travessia em faixa sinalizada e não semaforizada, o conceito inicial de conformidade temporal elaborado por Rouphail (1984) precisa ser adaptado para os parâmetros de investigação propostos pelo método para o entendimento do comportamento do pedestre. O tempo de travessia pode ser considerado ideal se indicar que a relação entre o espaço de travessia (largura da via a ser transposta) e o tempo cronológico de travessia se aproxima da velocidade de caminhada natural do pedestre, quando este se desloca pelos passeios e calçadas. Assim, o tempo de travessia seria constante, sem sofrer alterações entre o tempo inicial e o tempo final de travessia.

Mas, como o ideal comumente se distancia do real, surge a possibilidade de análise da conformidade temporal através da análise do tempo real de travessia, dividindo o tempo de travessia em duas partes: o tempo de espera para iniciar a travessia e o tempo de travessia na faixa. Assim, pode-se considerar como tempo total de travessia a soma do tempo de espera para iniciar a travessia com o tempo de caminhada sobre a faixa, conforme indica a equação a seguir:

$$
\mathrm{T}_{\mathrm{T}}=\mathrm{T}_{\mathrm{E}}+\mathrm{T}_{\mathrm{F}}
$$

Onde:

$\mathrm{T}_{\mathrm{T}}$ : tempo total de travessia

$\mathrm{T}_{\mathrm{E}}$ : tempo de espera

$\mathrm{T}_{\mathrm{F}}$ : tempo na faixa 
É de conhecimento geral que as travessias influenciam o conforto e o tempo de viagem, geralmente proporcionando insegurança e atrasos. A fragmentação do tempo total de travessia é útil para a entendimento do comportamento do pedestre pois identifica os possíveis pontos críticos relacionados à utilização das faixas.

Um tempo de espera maior para iniciar a travessia pode indicar, por exemplo, que o pedestre se sente inseguro para iniciar a travessia, por não reconhecer o direito de uso do espaço delimitado da faixa como um direito do pedestre ou pelo fato dos motoristas não pararem na faixa, mesmo quando visualizam o pedestre. Já um tempo curto, pode indicar tanto que os motoristas reconhecem a prioridade do pedestre na travessia e param diante da faixa, quanto um comportamento de risco por parte do pedestre em relação à travessia.

Durante a travessia, a variação do tempo de permanência na faixa pode indicar: i) desconforto enquanto atravessa a rua, quando o pedestre acelera a marcha para sair logo do espaço de conflito com os veículos; ii) falta de percepção da travessia como um momento que exige uma postura atenta, quando o pedestre se distrai enquanto atravessa a rua, diminuindo a velocidade de caminhada ou sem observar o movimento dos veículos próximos à faixa. Em qualquer uma dessas duas situações, o conhecimento do comportamento de travessia pode auxiliar a estimação do tempo correto para a travessia, sem que o pedestre acelere ou desacelere a marcha.

Se o tempo na faixa for constante, isso pode indicar que o pedestre reconhece aquele espaço de travessia como seu por direito, e o utiliza no tempo necessário, assim, anda normalmente, sem acelerar nem diminuir a marcha de caminhada durante a travessia. No método, é considerada conformidade temporal a situação em que o pedestre mantém uma velocidade constante de travessia, semelhante à sua velocidade de caminhada em seus deslocamentos, juntamente com um tempo de espera baixo - refugando a aceitação de brechas e indicando o desejo de travessia para interromper o fluxo de veículos. Verificada a conformidade temporal de travessia, deve-se analisar a situação de conformidade com o sistema de trânsito.

\subsubsection{Conformidade com o sistema de trânsito}

O conceito de conformidade com o sistema de trânsito é aqui definido na tentativa de, através do MIPP, verificar o quão o pedestre tem consciência de seus direitos e deveres como atuante 
nesse sistema. Para utilizar as vias urbanas é exigido dos condutores de veículos motorizados um treinamento como parte do processo de habilitação para esse uso. Esse treinamento, geralmente fornecido pelos centros de formação de condutores, nada diz a respeito dos direitos e deveres daquele motorista como pedestre e nem em relação ao pedestre.

O pedestre partilha o sistema de circulação urbano com veículos motorizados ou não, com equipamentos urbanos e com outras pessoas enquanto se desloca. $\mathrm{O}$ artigo primeiro do Código de Trânsito Brasileiro (CTB, 1997) traz, logo no primeiro parágrafo, "considera-se trânsito a utilização das vias por pessoas, veículos e animais, isolados ou em grupos, conduzidos ou não, para fins de circulação, parada, estacionamento e operação de carga ou descarga”. O CTB (1997), que ainda é falho em relação inclusive à definição do conceito de pedestre, conforme abordado no item 2.1.1, não apresenta clareza em definir os direitos e deveres do pedestre em relação à utilização de vias e travessia de vias.

O site do governo do Reino Unido (GOV.UK, 2015) apresenta trinta e cinco regras de conduta dos pedestres, na tentativa de direcionar o comportamento em diversas situações. Se trata de um guia contendo questões de orientação geral de conduta durante os deslocamentos dos pedestres, nos momentos de iniciar a travessia, durante a travessia e em situações onde é necessária atenção especial (como aproximação de ambulâncias, embarque e desembarque de transporte público).

A necessidade de uma orientação direcionada para a conduta dos pedestres, e dos motoristas em relação aos pedestres, é evidenciada pelo fato do pedestre ser o usuário mais frágil do sistema de trânsito. A Figura 4.2 propõe uma adaptação do esquema apresentado pela Abordagem Sistêmica de Segurança (OPAS, 2013 - ver figura 3.5, item 3.1), conferindo prioridade ao ser humano no sistema de circulação e indicando o conhecimento do comportamento como critério de entrada no sistema. 


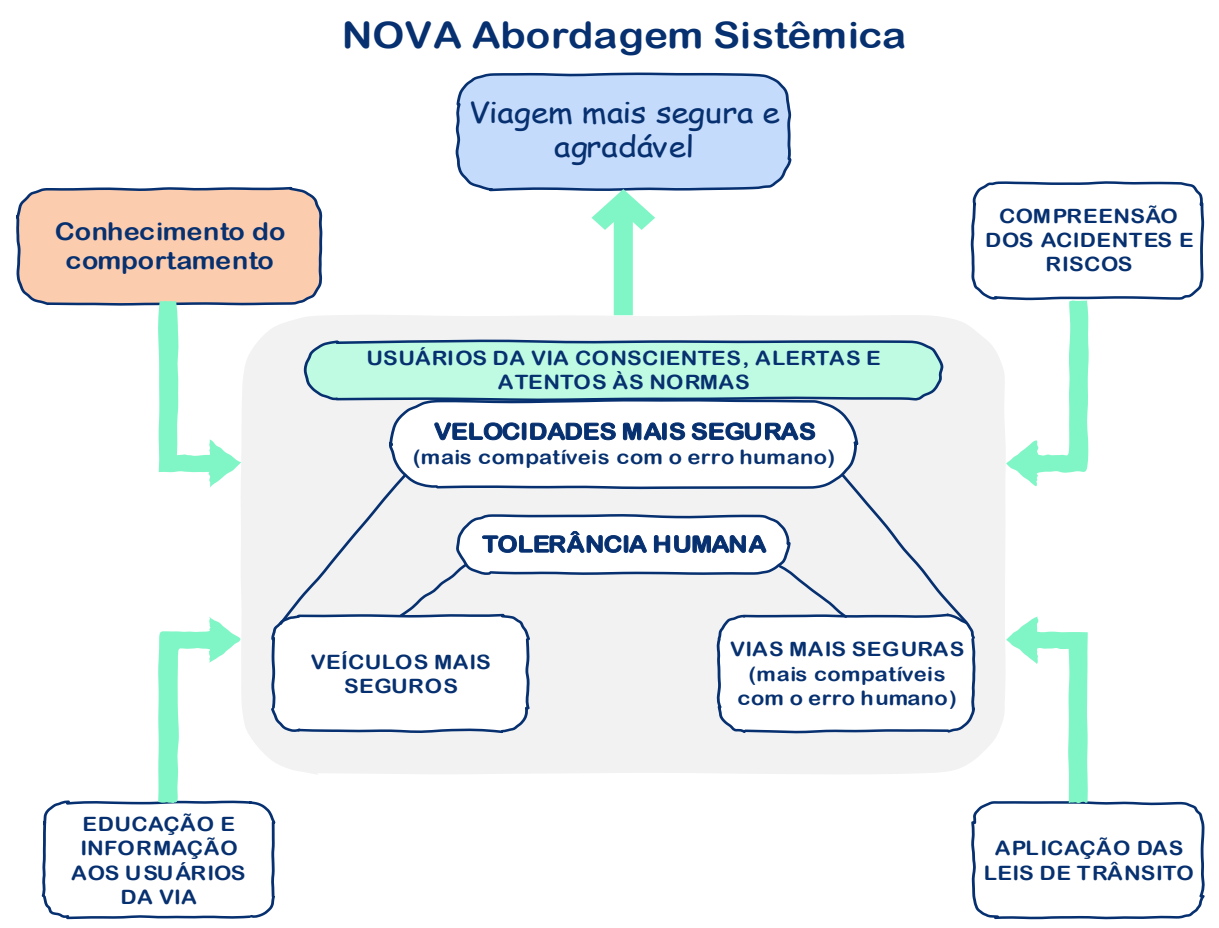

Figura 4.2 - Proposta de uma nova abordagem sistêmica de segurança tendo o conhecimento do comportamento como entrada do sistema.

A figura apresenta, de forma esquemática, todos os critérios básicos de observação do comportamento relacionado à visibilidade, velocidade de travessia e atenção durante o processo. Esses critérios foram ligados aos conceitos de conformidade espacial e temporal e à proposta do conceito de conformidade com o sistema de trânsito, que visa identificar a consciência do pedestre como elemento do sistema, resultando em caminhadas mais seguras e agradáveis.

A definição do conceito de conformidade com o sistema de trânsito tem a finalidade de investigar o nível de consciência do pedestre, em relação à sua atuação como agente do sistema de trânsito, quando realiza uma travessia. Pretende-se investigar se o pedestre, enquanto atravessa a rua, desempenha algum comportamento distraído, que possa acarretar danos à segurança física e psicológica do próprio pedestre e também do motorista ou de outro pedestre. Desta forma, é considerada conformidade com o sistema de trânsito na faixa de pedestre não semaforizada, quando o pedestre realiza a travessia observando atentamente o fluxo de veículos, em velocidade constante do início ao fim da travessia que foi iniciada com a manifestação clara de interromper o fluxo de veículos. 
A partir da definição desse conceito fica estabelecida uma hierarquia da conformidade com o sistema de trânsito perante a conformidade temporal de travessia, e desta última em relação à conformidade espacial de travessia. Só há conformidade com o sistema de trânsito após as conformidades temporais e espaciais se confirmarem.

\subsubsection{Definição do Modelo Conceitual}

A função de um modelo conceitual é representar, de forma simplificada, as principais características de um fenômeno de investigação. A primeira etapa de elaboração do método consiste na definição de um modelo conceitual que deve apresentar, através de elementos ordenados, uma estrutura proposta para compreensão do comportamento dos pedestres ao realizarem uma travessia, em faixa de pedestre não semaforizada.

O modelo conceitual do MIPP procura representar os perfis dos diferentes comportamentos dos pedestres durante a travessia em faixa sinalizada, identificados por meio de observações in loco e esquematizados segundo os parâmetros de conformidade de travessia descritos anteriormente. Acredita-se que este fenômeno, mesmo sendo influenciado por diversos outros fatores, além das variáveis individuais (características sócio demográficas e histórico culturais) e ambientais (fixas e variáveis), pode ser representado pelas características observadas do comportamento de pedestres e motoristas em relação à faixa de pedestres.

O objetivo do modelo é representar o padrão de comportamento de pedestres pela identificação de perfis de comportamentos, observando as diferentes formas de travessia. $\mathrm{O}$ desenvolvimento do modelo exigiu a adoção de uma conceituação para o termo pedestre, descrito no item 2.1.1, que partiu da adoção de três princípios básicos: a forma de deslocamento terrestre; a tração humana como força motriz preferencial; a velocidade de deslocamento, que deve ser de grandeza semelhante à desenvolvida por uma pessoa que caminha a pé.

Para a concepção do modelo conceitual do comportamento do pedestre durante a travessia na faixa, foram utilizados dados observacionais obtidos através de filmagens de travessias, com qualidade de vídeo HD (High Definition), num total de 50 travessias, todas localizadas no Plano Piloto de Brasília. Deste total, 23 observações ocorreram na Via L3 Norte, em local próximo à Faculdade de Tecnologia da Universidade de Brasília. Outras 11 observações, 
foram feitas em dois locais da Primeira Avenida do Setor Sudoeste, CLSW 104/304 e CLSW 103/303 (CLSW = Comércio Local Sudoeste). O restante (16 observações) foi feito nas faixas de pedestres distribuídas entre quadras residenciais da Asa Norte (206/406, 207/407 e 208/408).

A análise dos vídeos permitiu a classificação do comportamento dos pedestres, quanto aos parâmetros de conformidade de travessia, em quatro comportamentos identificados. Conforme descrito anteriormente, a conformidade espacial é a condição necessária para a verificação da conformidade temporal, e esta última, consideração necessária para a conformidade com o sistema de trânsito. Assim, foi utilizada a classificação de comportamentos de acordo com conformidade de travessia em faixas não semaforizadas proposta e, para a construção do modelo conceitual, apresentado na Figura 4.3, foram identificados e classificados os comportamentos dos pedestres, quanto às conformidades em:

Inseguro: caracterizado pelo pedestre que não interrompe o fluxo de veículos, por meio de sinalização manual, e aguarda um momento propício para a travessia, considerando uma brecha aceitável no fluxo de veículos para atravessar a via em segurança.

Hesitante: representado pelo pedestre que interrompe o fluxo de veículos, mas acelera ou diminui a marcha de caminhada, alterando o tempo de travessia na faixa.

Assertivo: identifica o pedestre que interrompe o fluxo de veículos, realiza toda a travessia sem acelerar a marcha de caminhada em seu deslocamento. Duas variações podem ser observadas neste comportamento:

(i) o pedestre que realiza toda a travessia observando o fluxo de veículos, busca contato visual com os motoristas e não altera a velocidade da marcha de caminhada - considerado "assertivo atento" e,

(ii) o pedestre "assertivo distraído" que começa a travessia e não observa mais o fluxo de veículos, às vezes chega a reduzir a velocidade da marcha de caminhada durante a travessia, para conversar com outras pessoas ou utilizar equipamentos eletrônicos, como o telefone celular. 


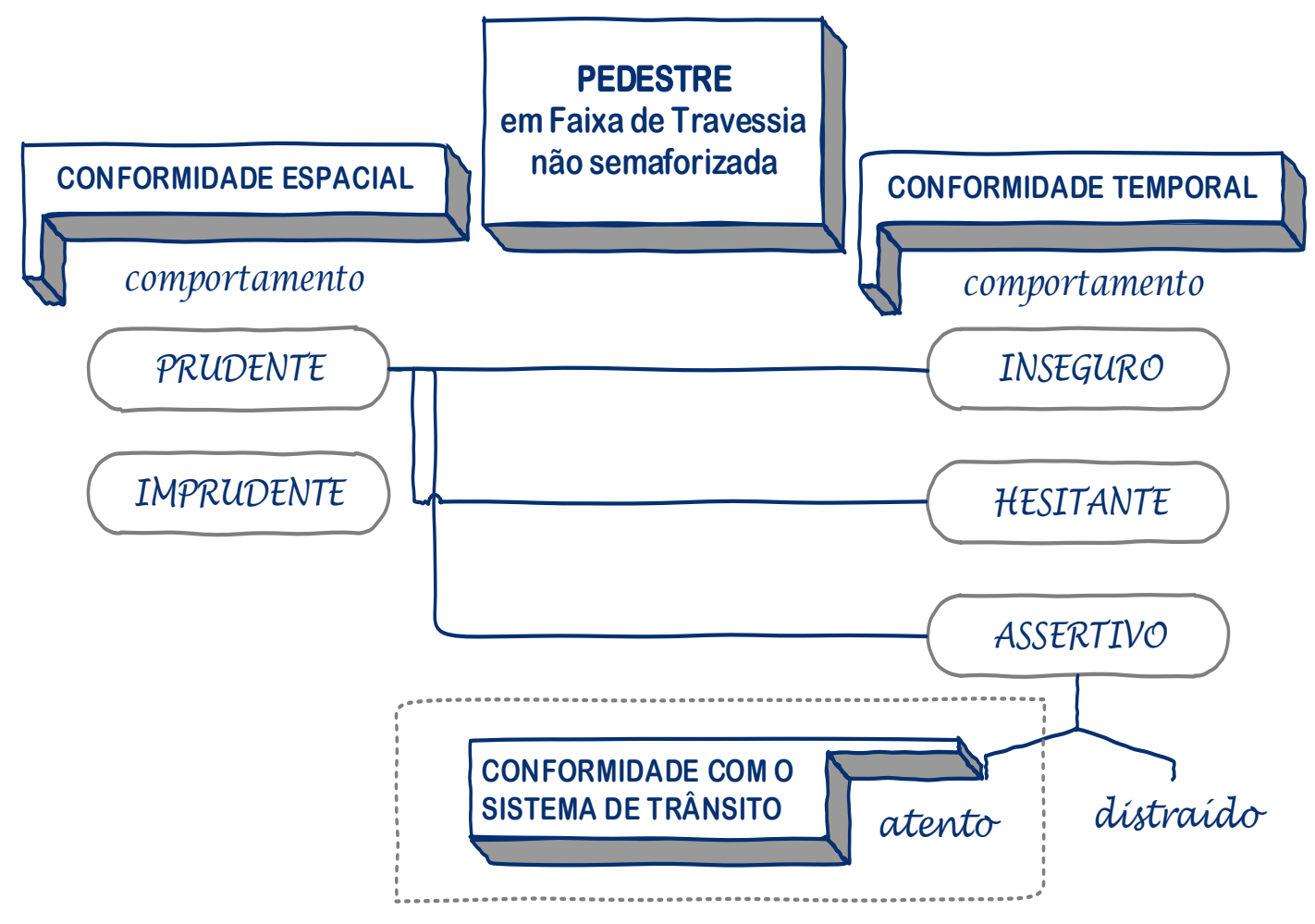

Figura 4.3 - Modelo conceitual do comportamento dos pedestres em momento de travessia.

A representação da forma em que o modelo conceitual proposto pelo método se ajusta ao modelo proposto pela Teoria do Comportamento Planejado (AJZEN, 1991) é apresentada pela Figura 4.4. Os construtos constituintes da TCP antecedem à intenção de desempenhar determinado comportamento. No método a intenção está relacionada à decisão de atravessar no local demarcado pela faixa de pedestres, indicando a conformidade espacial necessária para o desenvolvimento da análise do perfil do pedestre. 


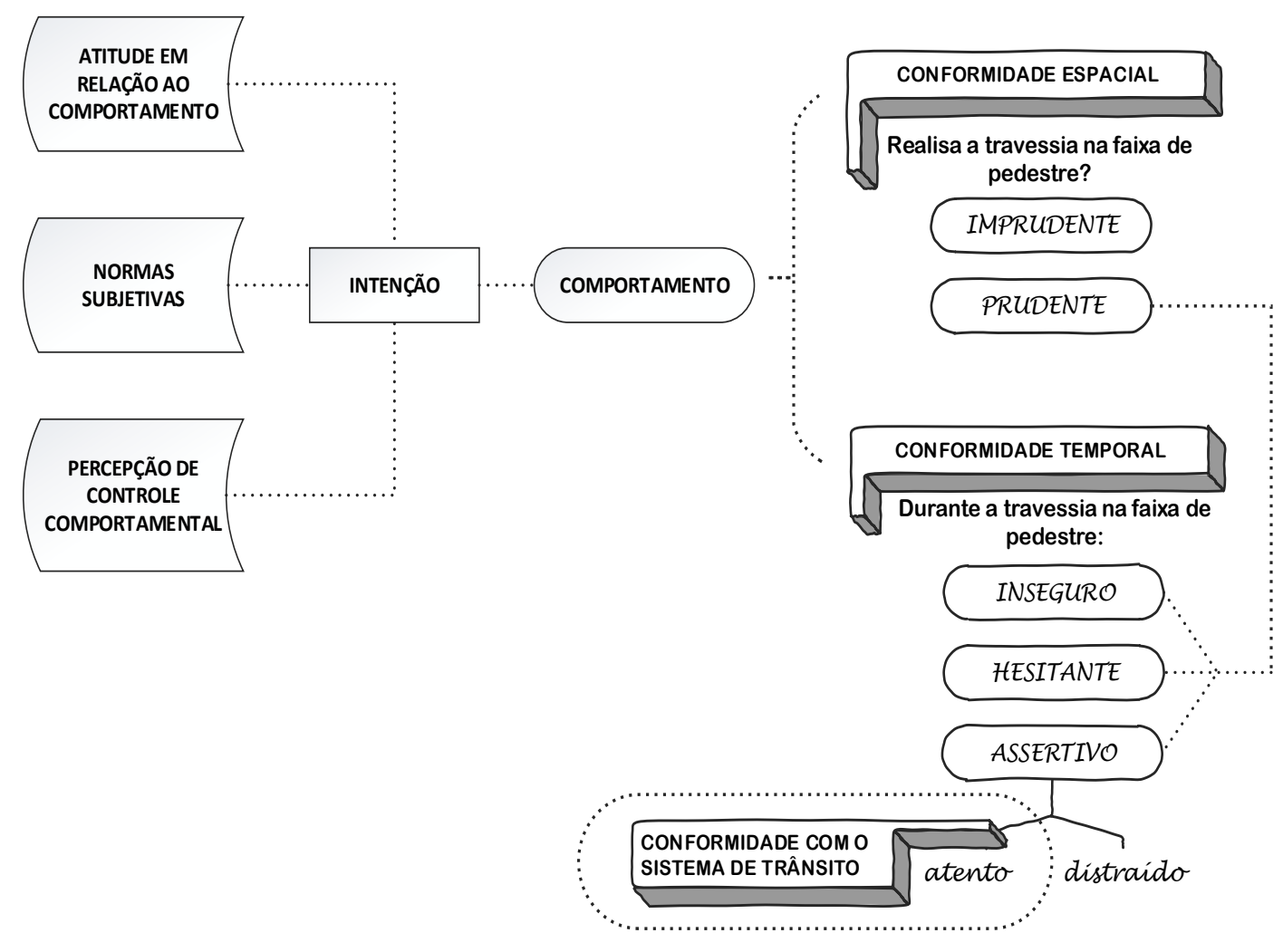

Figura 4.4 - Modelo Conceitual ajustado ao modelo da Teoria do Comportamento Planejado proposto por Ajzen (1991).

A construção do modelo conceitual final foi realizada através da agregação dos diferentes comportamentos dos pedestres observados quando estes abordam a faixa para realizar uma travessia, unindo as características de comportamento aos critérios definidos para a conformidade da travessia em faixas não semaforizadas. A estrutura do modelo conceitual propõe a classificação dos pedestres de acordo com suas atitudes ao atravessar uma via. Com relação à conformidade de travessia espacial, os pedestres classificam-se em prudentes e imprudentes.

Em relação à conformidade de travessia temporal, os pedestres classificam-se em inseguros, hesitantes e assertivo. Os critérios de conformidade com o sistema de trânsito subdividem os pedestres assertivos em atentos e distraídos. Todos esses parâmetros auxiliaram a esquematização do comportamento do pedestre ao realizar a travessia, permitindo a representação dos comportamentos relacionados com a ordem de conformidade de cada momento da travessia (Figura 4.5). 

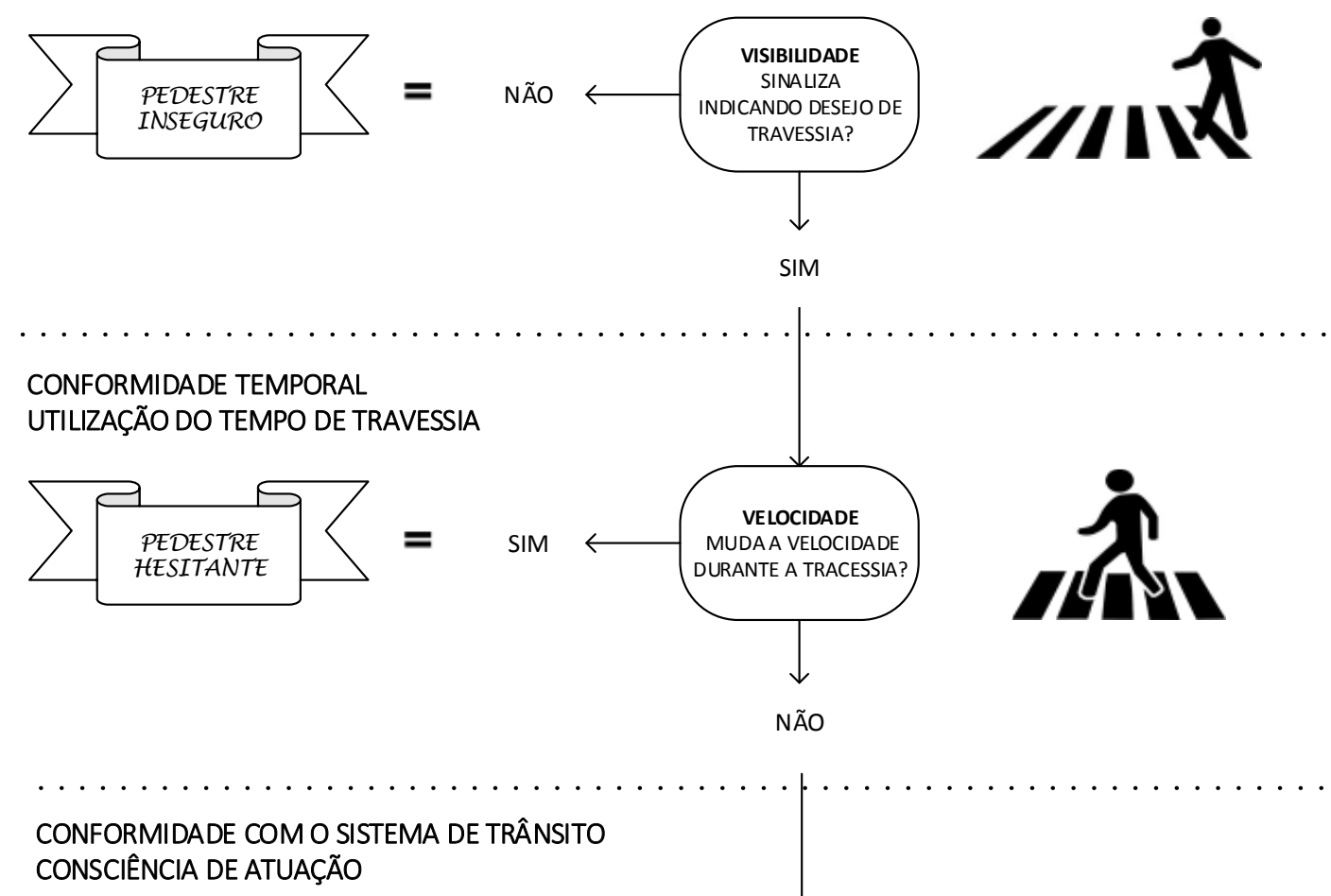

CONFORMIDADE COM O SISTE
CONSCIÊNCIA DE ATUAÇÃO
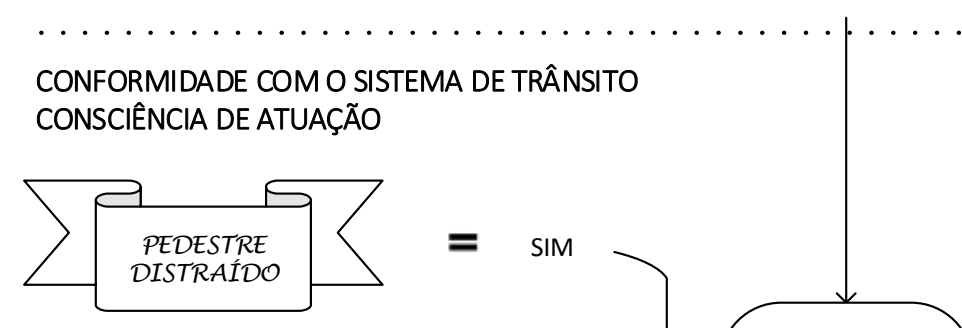

\section{ATENÇÃO} SE DISTRAI DURANTE A TRAVESSIA?

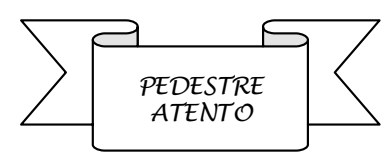

$=\quad \mathrm{N} \tilde{\mathrm{A} O}$
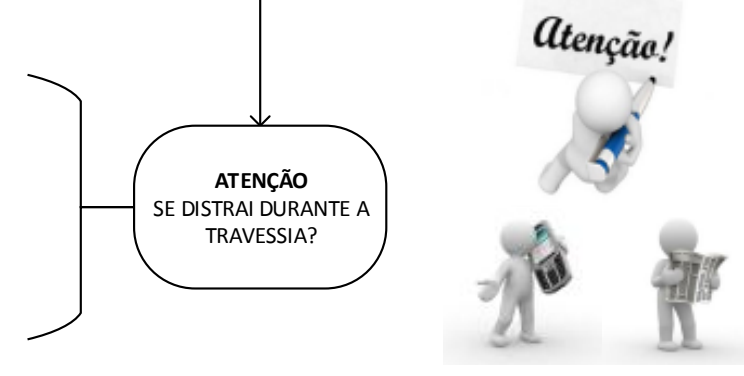

Figura 4.5 - Modelo conceitual de conformidade de travessia em faixas não semaforizadas.

A definição do esquema estruturado do modelo conceitual de conformidade permitiu a elaboração de critérios para a investigação de algumas características de comportamento dos pedestres durante a travessia na faixa, indicando diferentes perfis cujo o entendimento é pretendido através da aplicação do MIPP. O método pretende conhecer o perfil predominante dos pedestres de uma determinada localidade, que reúna uma grande quantidade de pessoas (escolas, universidades, repartições públicas, aglomerados comerciais etc.) e, a partir desse conhecimento propor medidas de intervenções que possam agregar qualidade para os deslocamentos feitos a pé em centros urbanos. 


\subsection{Etapa 2: LeVANTAMENTo das CRenÇAS SAlienteS}

A Teoria do Comportamento Planejado - TCP (AJZEN, 1991), afirma que a ação humana passa por três tipos de considerações: (i) as crenças pessoais, segundo as quais se avaliam as consequências prováveis de um comportamento, gerando uma atitude favorável ou desfavorável em relação a este comportamento; (ii) as crenças normativas, que representam a expectativa de terceiros sobre tal comportamento e assim constituem as normas subjetivas; e (iii) as crenças sobre fatores de controle, que podem favorecer ou prejudicar o desempenho do comportamento em questão, compondo a percepção de controle do comportamento. As atitudes, normas subjetivas e as percepções de controle comportamental formarão, segundo Ajzen $(1985,1991)$, a intenção do indivíduo em realizar um comportamento coerente com as suas crenças pessoais.

A etapa 2 de elaboração do MIPP foi realizada através da aplicação de um questionário aberto, composto por questões subjetivas de livre resposta (ver apêndice I), cujo objetivo foi obter os resultados comportamentais facilmente acessíveis, referentes normativos, e fatores de controle - referentes aos construtos da TCP que precedem a intenção, representados no extremo esquerdo da Figura 4.4 (item 3.3.2). Assim, o questionário aberto incluiu os itens que foram formulados para obter medidas diretas de atitude em relação ao comportamento, norma percebida e percepção de controle comportamental. Uma amostra de indivíduos da população de pesquisa foi utilizada para identificar resultados sobre as crenças de atitude, crenças normativas e crenças de controle associadas à forma de utilização da faixa de pedestres durante a travessia.

De forma geral, no questionário aberto, é solicitado ao respondente que escreva os pensamentos imediatos que lhe vem à mente a respeito de:

i) Vantagens e desvantagens relativas a determinado comportamento;

ii) Referências normativas em relação ao comportamento investigado, para verificar a expectativa de outras pessoas em ralação ao comportamento apresentado pelo respondente; $\mathrm{e}$

iii) Fatores de controle que poderiam facilitar ou dificultar que o entrevistado desempenhe o comportamento investigado. 
As crenças salientes, a serem levantadas de forma espontânea a partir das respostas obtidas pelo questionário aberto, devem ser incorporadas ao questionário fechado a ser elaborado e aplicado na Etapa 3. A princípio, devem ser transportadas para o questionário fechado da próxima etapa as crenças mais mencionadas pelos sujeitos participantes do questionário aberto, sem a necessidade de definição de um número exato de menções, mas podem ser excluídas as crenças que contarem com um número inferior a duas citações (VELLOSO, 2014). O término da pesquisa se dá por saturação das respostas, sendo a saturação um instrumento epistemológico que determina quando as observações deixam de ser necessárias, pois nenhum novo elemento permite ampliar o número de propriedades do objeto investigado.

A análise de conteúdo das respostas às perguntas do questionário piloto fornecerá os resultados de crenças salientes e fatores de controle. Estes resultados foram utilizados para construir os itens a serem incluídos no questionário fechado, que constituiu a etapa 3 do método. O levantamento foi feito individualmente em um formato de resposta livre, utilizando a plataforma eletrônica Srvey, desenvolvida pelo Grupo de Comportamento em Transportes e Novas Tecnologias na base Lime Survey.

O questionário aberto (Apêndice I) foi submetido a um grupo aleatório de pessoas, que receberam o convite para participar voluntariamente da pesquisa por correio eletrônico. As perguntas tiveram a finalidade de obter dos respondentes suas crenças de atitude, crenças normativas e crenças de controle associadas ao comportamento de atravessar vias na faixa de pedestres, de forma assertiva e atenta, de acordo com a conformidade de travessia proposta pelo modelo conceitual. A amostra para levantamento das crenças salientes consistiu de 45 respondentes e o término da pesquisa se deu por saturação das respostas.

A dificuldade maior do emprego do critério de saturação foi relativa ao dimensionamento da amostra da pesquisa, pois não houve possibilidade de prognosticar o tamanho da amostra e o tempo necessários à saturação. O levantamento das crenças salientes da segunda etapa do método contou com 28 questionários válidos (respondidos completamente) e, praticamente salientando as mesmas respostas chave, conforme é apresentado na Tabela 4.1. 
Tabela 4.1 - Crenças Salientes reveladas na Etapa 2 de elaboração do MIPP.

\begin{tabular}{|c|c|c|}
\hline \multicolumn{3}{|c|}{ CREnÇAS Salientes } \\
\hline \multirow{3}{*}{ 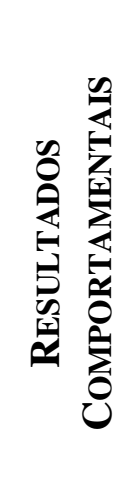 } & $\begin{array}{l}\text { O que você vê como vantagem de atravessar a rua } \\
\text { de forma segura, utilizando a faixa de pedestres } \\
\text { não semaforizada? }\end{array}$ & $\begin{array}{l}\text { Segurança de não me } \\
\text { envolver em acidentes. }\end{array}$ \\
\hline & $\begin{array}{l}\text { O que você vê como desvantagem de atravessar a } \\
\text { rua de forma segura, utilizando a faixa de } \\
\text { pedestres não semaforizada? }\end{array}$ & $\begin{array}{l}\text { Ter que me deslocar até a } \\
\text { faixa que está fora da } \\
\text { minha rota. }\end{array}$ \\
\hline & $\begin{array}{l}\text { O que mais vem à sua mente quando você pensa } \\
\text { sobre atravessar a rua de forma segura, utilizando } \\
\text { a faixa de pedestres não semaforizada? }\end{array}$ & $\begin{array}{l}\text { A preocupação se o carro } \\
\text { vai parar. }\end{array}$ \\
\hline \multirow{2}{*}{ 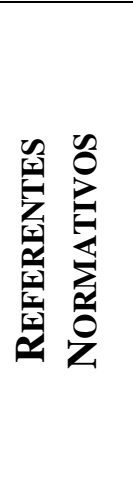 } & $\begin{array}{l}\text { Por favor, liste os indivíduos ou grupos (amigos, } \\
\text { família, companheiro(a), colegas de estudo ou } \\
\text { trabalho) que iriam aprovar o seu pensamento de } \\
\text { atravessar a rua de forma segura, na faixa de } \\
\text { pedestres não semaforizada. }\end{array}$ & Todos aprovam. \\
\hline & $\begin{array}{l}\text { Por favor, liste os indivíduos ou grupos (amigos, } \\
\text { família, companheiro(a), colegas de estudo ou } \\
\text { trabalho) que desaprovariam ou pensam que você } \\
\text { não deve atravessar a rua de forma segura, na } \\
\text { faixa de pedestres não semaforizada. }\end{array}$ & Ninguém desaprova. \\
\hline \multirow{2}{*}{ 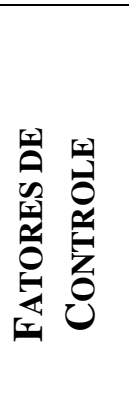 } & $\begin{array}{l}\text { Por favor, liste quaisquer fatores ou circunstâncias } \\
\text { que tornam mais fácil ou lhe permitam atravessar } \\
\text { a rua, na faixa de pedestres não semaforizada, de } \\
\text { forma segura. }\end{array}$ & $\begin{array}{l}\text { Sinalização da faixa; } \\
\text { iluminação da travessia; } \\
\text { baixas velocidades }\end{array}$ \\
\hline & $\begin{array}{l}\text { Por favor, liste quaisquer fatores ou circunstâncias } \\
\text { que dificultam ou impedem de atravessar a rua, na } \\
\text { faixa de pedestres não semaforizada, de forma } \\
\text { segura. }\end{array}$ & $\begin{array}{l}\text { Velocidade dos carros; } \\
\text { baixa visibilidade da faixa } \\
\text { por falta de iluminação e } \\
\text { sinalização. }\end{array}$ \\
\hline
\end{tabular}

Os resultados da segunda etapa evidenciaram que as normas subjetivas, em um levantamento não muito aprofundado a respeito, mostraram ser um fator importante para realizar o comportamento esperado. Das 28 respostas analisadas, no quesito "Referentes Normativos", apenas dois respondentes consideraram grupos que poderiam desaprovar o comportamento de atravessar na faixa de maneira assertiva e atenta. Os grupos citados nessas respostas foram: pais e avós em um questionário, e amigos em outro. Por se tratar de uma análise de resultados por saturação, essas duas respostas não foram consideradas relevantes. 


\subsection{ETAPA 3: LEVANTAMENTO DAS VARIÁVEIS DE INTERESSE}

Esta etapa foi realizada através da elaboração de um questionário fechado, com questões de múltipla escolha, em que serão levantados os construtos de investigação e algumas variáveis pertinentes apontadas pelas etapas 1, 2 e pela revisão bibliográfica. $\mathrm{O}$ presente trabalho pretende determinar construtos de investigação, baseados na conformidade de travessia e na TCP, que identifiquem o perfil predominante dos pedestres de uma determinada região. Além da identificação do perfil de comportamento, serão coletados dados sobre alguns construtos relevantes da TCP, obtidos na primeira etapa pelo questionário aberto, além de informações sócio demográficas e histórico culturais dos respondentes. A seguir cada parte constituinte do questionário fechado é detalhada - o questionário final é composto por quatro partes e está apresentado de forma integral no Apêndice II.

\subsubsection{Parte I - Identificação do perfil do pedestre}

Nesta etapa da pesquisa procurou-se reproduzir, em forma de cenários, uma situação de travessia, onde o respondente irá eleger os comportamentos mais característicos que representam a sua forma de atravessar a rua no contexto apresentado. Foi utilizado um contexto de travessia, onde o respondente é convidado a se imaginar caminhando nas proximidades do local ou região pesquisada. A partir dessa situação imaginada, você identificará a opção que mais representa o seu comportamento na travessia, em três contextos diferentes: i) atravessando sozinho; ii) atravessando com um grupo de pessoas desconhecidas; iii) atravessando acompanhado de alguém importante para você. O respondente deverá eleger entre as alternativas de comportamentos apresentados os que mais representam o seu comportamento durante a travessia.

As respostas dessas questões indicará o comportamento do pedestre respondente em relação: (i) ao início da travessia - em que é investigado o quesito de conformidade espacial, através da relação de reconhecimento e posse do espaço de travessia por parte do pedestre; (ii) ao tempo de realização da travessia - onde prevalece a questão da conformidade temporal pela avaliação da variação de velocidade durante a travessia; e (iii) à atenção ao fluxo de veículos enquanto realiza a travessia - aqui é avaliada a conformidade com o sistema de trânsito, ao questionar a consciência dos deveres do pedestre para promover a segurança da travessia. As três fases travessia descritas obedecem ao modelo conceitual baseado na conformidade de travessia. O objetivo é identificar o perfil do pedestre enquanto faz a travessia sozinho e 
as modificações do seu comportamento sob influência de outras pessoas, desconhecidas ou não.

A partir desta identificação é possível direcionar um planejamento da travessia mais eficiente, por justamente buscar atingir o ponto crítico de não conformidade (espacial, temporal ou com o sistema de trânsito) do comportamento dos pedestres durante a travessia em faixas não semaforizadas. Ao abordar o comportamento de travessia sob influência de outras pessoas, pretende-se vislumbrar o efeito da norma social nas crenças pessoais do indivíduo.

\subsubsection{Aplicação do Modelo Conceitual de Conformidade}

Os conceitos de conformidade de travessia embasaram a construção de um modelo conceitual do comportamento de pedestres em travessias de vias em faixas sinalizadas e não semaforizadas (Figura 4.5, item 4.2.2). A construção do modelo foi realizada através da agregação de observações registradas em vídeo do comportamento dos pedestres durante a travessia. A partir da análise dessas observações (descritas no item 4.2.2) foram elencados alguns comportamentos esperados dos pedestres em situações de travessia.

É de conhecimento comum que a forma de travessia na faixa não semaforizada depende tanto do comportamento do pedestre quanto do motorista, sendo a comunicação entre ambos imprescindível. O pedestre se sente mais confortável para fazer a travessia na faixa quando o motorista demonstra respeito a esse local. Por outro lado, o motorista será incentivado a respeitar a faixa quando o pedestre faz uso desse espaço para a travessia. Entretanto, a essa altura do texto já ficou claro que não é foco deste trabalho investigar o comportamento do motorista, mas a observação desse comportamento como premissa para analisar o comportamento do pedestre em determinado local de aplicação da pesquisa é fundamental.

A elaboração das questões que constituem a etapa de identificação do perfil quando o pedestre atravessa sozinho se amparou em registros de uma segunda amostra de observações de travessias. Para tal, algumas ações de pedestres e motoristas, que desencadeiam um comportamento considerado positivo em relação à interação entre ambos, durante a travessia em faixas não semaforizadas, foram relatadas. Esses comportamentos foram observados em um levantamento preliminar (item 4.2.2), descritos em uma planilha (Tabela 4.2), levados a campo para uma pesquisa piloto, e utilizados para o levantamento da pesquisa de observação. 
Tabela 4.2 - Itens de avaliação do comportamento de pedestres e motoristas. Fonte: Margon e Taco (2014).

\begin{tabular}{|c|c|}
\hline \multicolumn{2}{|r|}{ PEDESTRES } \\
\hline ITEM OBSERVADO & COMPORTAMENTO ESPERADO \\
\hline $\begin{array}{l}\text { Ações do pedestre ao se } \\
\text { aproximar da faixa }\end{array}$ & $\begin{array}{l}\text { O pedestre se coloca em frente à travessia sinalizada, em } \\
\text { posição visível ao fluxo de veículos. }\end{array}$ \\
\hline $\begin{array}{l}\text { Sinalização antes de iniciar a } \\
\text { travessia }\end{array}$ & $\begin{array}{l}\text { O pedestre acena com a mão, solicitando a passagem para o } \\
\text { fluxo de veículos. }\end{array}$ \\
\hline $\begin{array}{l}\text { Espera pela parada completa } \\
\text { dos veículos }\end{array}$ & $\begin{array}{l}\text { O pedestre só inicia a travessia quando o veículo mais próximo } \\
\text { para na faixa, considerando a situação cuja proximidade do } \\
\text { veículo não permita uma brecha suficiente para a travessia. }\end{array}$ \\
\hline $\begin{array}{l}\text { Observação do fluxo antes } \\
\text { da travessia }\end{array}$ & $\begin{array}{l}\text { O pedestre observa o fluxo de veículos, buscando contato } \\
\text { visual com os motoristas, antes de começar a travessia. }\end{array}$ \\
\hline $\begin{array}{l}\text { Observação do fluxo durante } \\
\text { a da travessia }\end{array}$ & $\begin{array}{l}\text { O pedestre observa o fluxo de veículos, e permanece atento ao } \\
\text { fluxo, buscando contato visual com os motoristas, durante a } \\
\text { travessia. }\end{array}$ \\
\hline $\begin{array}{l}\text { Observação da velocidade } \\
\text { dos veículos nas faixas } \\
\text { subsequentes }\end{array}$ & $\begin{array}{l}\text { O pedestre reduz a velocidade de travessia, antes de avançar a } \\
\text { próxima faixa de tráfego, ao perceber que não houve redução } \\
\text { de velocidade dos veículos. }\end{array}$ \\
\hline \multicolumn{2}{|r|}{ MOTORISTAS } \\
\hline ITEM OBSERVADO & COMPORTAMENTO ESPERADO \\
\hline $\begin{array}{l}\text { Respeito ao sinal de travessia } \\
\text { do pedestre }\end{array}$ & $\begin{array}{l}\text { O motorista, ao perceber a sinalização do pedestre, } \\
\text { imediatamente começa a reduzir a velocidade e para na faixa. }\end{array}$ \\
\hline $\begin{array}{l}\text { Espera pela travessia } \\
\text { completa do pedestre }\end{array}$ & $\begin{array}{l}\text { O motorista permanece parado na faixa, até que o pedestre } \\
\text { realize a travessia completa, alcançando a calçada ou o canteiro } \\
\text { central. }\end{array}$ \\
\hline $\begin{array}{l}\text { Espera pela travessia de mais } \\
\text { de um pedestre }\end{array}$ & $\begin{array}{l}\text { O motorista está parado na faixa, percebe o início da travessia } \\
\text { de outro pedestre em uma faixa de tráfego diferente da sua, e } \\
\text { permanece parado até que essa travessia seja finalizada. }\end{array}$ \\
\hline $\begin{array}{l}\text { Motoristas que apressam a } \\
\text { travessia do pedestre }\end{array}$ & $\begin{array}{l}\text { O motorista } \mathrm{NÃO} \text { aciona o acelerador do veículo, causando um } \\
\text { barulho intimidador que faz com que o pedestre aumente a } \\
\text { velocidade de travessia. }\end{array}$ \\
\hline
\end{tabular}

O objetivo da pesquisa foi identificar quais comportamentos considerados positivos e negativos, em relação ao comportamento esperado de reconhecimento e respeito à faixa sinalizada, predominam durante a travessia. Foram relatados o comportamento de 170 pedestres e 250 motoristas, em três faixas de travessias para pedestres observadas, localizadas na Avenida L3 Norte, nas imediações do Campus Darcy Ribeiro da Universidade de Brasília (Figura 4.6). Essa pesquisa que fundamenta as questões da primeira etapa do questionário foi publicada em um artigo científico (MARGON e TACO, 2014). As travessias 
foram avaliadas considerando os conceitos de conformidade de travessia adaptados para o entendimento do comportamento dos pedestres durante a travessia nas faixas sinalizadas.

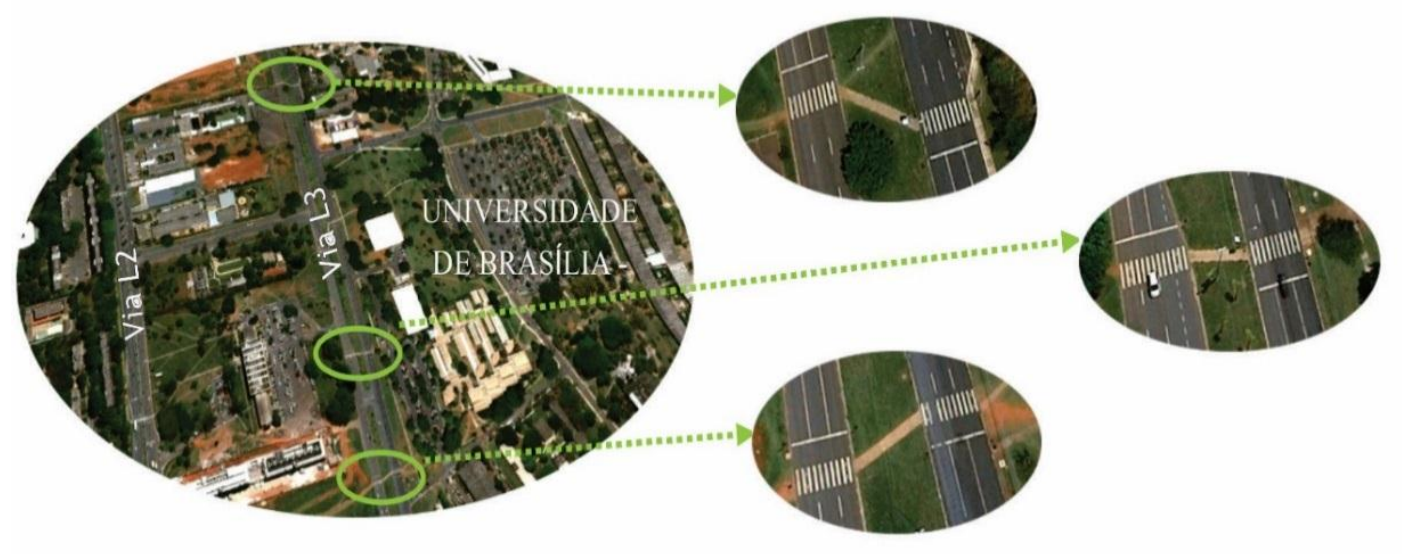

Figura 4.6 - Localização dos três pontos de pesquisa em faixas ao longo da via L3.

A análise dos comportamentos observados de pedestres e motoristas, confrontadas com os previstos na Tabela 4.2, mostrou que a maioria dos pedestres realizam a travessia na faixa em conformidade espacial e temporal (Figura 4.7). Já os motoristas respeitam o espaço delimitado pela faixa de travessia, mas não a conformidade temporal da travessia, desrespeitando o tempo total de travessia do pedestre e considerando como espaço de travessia somente a sua faixa de tráfego (Figura 4.8).



Figura 4.7 - Comportamento observado dos pedestres em relação à faixa de pedestres. Fonte: Margon e Taco (2014). 


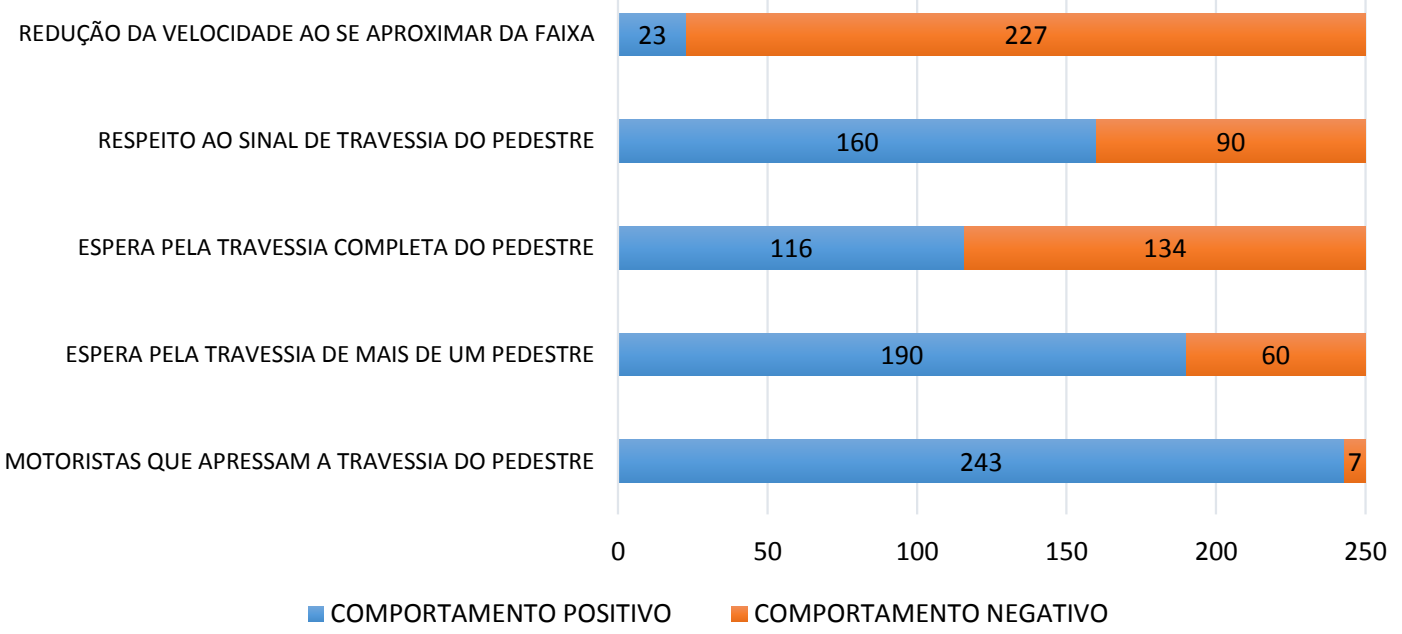

Figura 4.8 - Comportamento observado dos motoristas em relação à faixa de pedestres. Fonte: Margon e Taco (2014).

O intuito dessas observações foi confirmar se os comportamentos listados na Tabela 4.2 eram válidos para descrever as ações dos pedestres enquanto fazem a travessia. As planilhas utilizadas em campo continham um espaço para anotação de comportamentos observados diferentes dos utilizados como parâmetro, não houve relatos por parte dos pesquisadores de comportamentos representativos não listados que poderiam interferir na análise das conformidades de travessia.

O estudo observacional pode identificar comportamentos assertivos ao abordar a faixa, sinalizando para os motoristas, seguidos de comportamentos distraídos, nos quais a partir do momento em que começa a travessia, o pedestre deixa de observar o fluxo de veículos e realiza o cruzamento da via utilizando celulares e outros dispositivos eletrônicos, se permitindo até uma redução na marcha de caminhada. Esta atitude não é condenável, já que o pedestre tem a preferência de uso deste espaço, assegurada por lei (CTB, 1997). Mas a observação do fluxo de veículos pelos pedestres, antes e durante a travessia, é um quesito preventivo, de segurança, pois dependendo da velocidade de aproximação do automóvel e do nível de distração do motorista, caso este não veja o pedestre, a parada do veículo antes da faixa pode ser impossibilitada.

A utilização do espaço de travessia, demonstrada pelo comportamento dos pedestres que não observam cuidadosamente o fluxo de veículos, antes e durante o cruzamento das vias, mostra a conquista de uma política pública bem implementada em Brasília, mas carente de reforço 
para incentivar a necessidade de fazer a travessia de forma atenta. A investigação mais profunda do comportamento assertivo atento, com o levantamento das influências proporcionadas pelas atitudes dos motoristas e pela composição ambiental no entorno imediato da área de travessia, pode auxiliar na composição de cenários apropriados para encorajar atitudes positivas dos pedestres durante a travessia em faixas não semaforizadas.

Os resultados obtidos com a observação dos pedestres e motoristas foram fundamentais para o entendimento preliminar do comportamento dos pedestres durante a travessia em faixas não semaforizadas. A partir dos comportamentos observados para os pedestres, considerados positivos, pôde-se identificar grupos de pedestres com comportamentos semelhantes. A identificação destes grupos forneceu os critérios de avaliação do comportamento em cada etapa da conformidade de travessia. Através desses critérios foram elaboradas as questões 1 a 3 da "identificação do perfil" dos pedestres, presentes no questionário (ver apêndice II), que testam o comportamento dos pedestres verificando os quesitos de conformidade espacial, temporal e com o sistema de trânsito quando este faz a travessia sozinho.

\subsubsection{Influência de outras pessoas no comportamento de travessia}

O item 4.4.1.1 descreve a pesquisa observacional que embasou as questões para a identificação do pedestre quando este faz a travessia sozinho. A experiência do levantamento em campo sugeriu que o comportamento do pedestre pode sofrer influência de outras pessoas. Nas travessias em que foram observadas formações de grupos de pessoas para abordar a faixa no início da travessia, muitas vezes o gesto de sinalização com a mão indicando o desejo de travessia foi suprimido. Foi observado que as pessoas tendem a se aproximar umas das outras, formando um grupo mais coeso, e seguem a liderança de um pedestre que inicia a travessia.

A partir dessa constatação, foram feitas novas observações em faixas de pedestres. Nesta etapa da pesquisa foram realizadas filmagens de travessias e 74 entrevistas em duas faixas nas imediações do Campus Darcy Ribeiro (Figura 4.9), sendo 28 na travessia entre os blocos PJC e ICC Norte, e 46 delas na Avenida L3 Norte, na faixa que dá acesso à Faculdade de Tecnologia. A escolha dessas duas faixas de travessia deve-se aos seguintes fatores: i) as duas representam locais que concentram um grande volume de pedestres que acessam e circulam pelo campus universitário; ii) possuem características ambientais diferentes entre 
elas: a Avenida L3 Norte é constituída por duas pistas, com três faixas de tráfego cada separada por canteiro central; a via que separa os blocos PJC e ICC Norte está localizada dentro do campus universitário e possui duas faixas de tráfego sem separação por canteiro central. A intenção ao definir o segundo fator de escolha, que elegeu faixas posicionadas em locais com característica ambientais distintas, foi a de isolar comportamentos grupais que se repetissem nos dois locais. Com isso, na identificação do perfil do pedestre, pretende-se analisar o comportamento do pedestre com critérios descolados do ambiente de travessia.
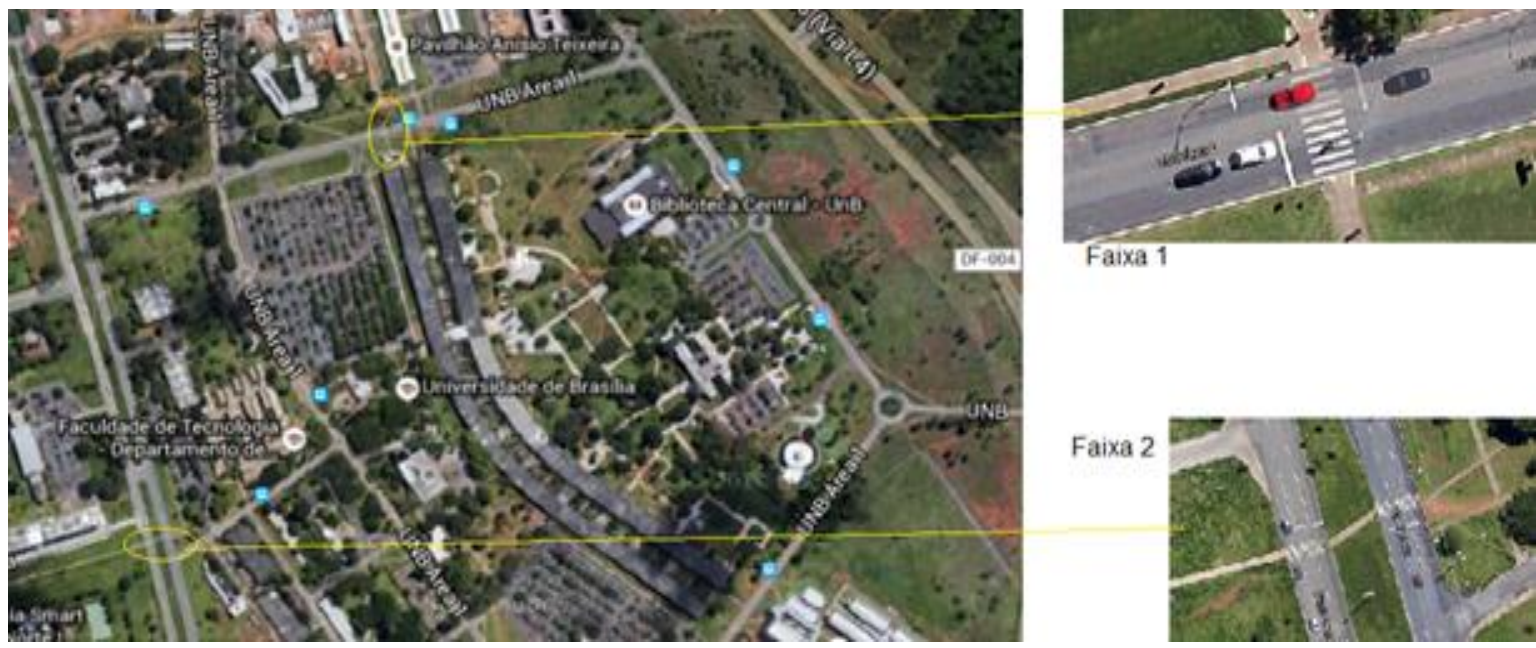

Figura 4.9 - Localização dos pontos de pesquisa: faixa entre os blocos PJC e ICC Norte (Faixa 1) e via L3 Norte - Faculdade de Tecnologia (Faixa 2)

Os levantamentos da pesquisa em questão foram realizados nos dias 4 e 5 de julho de 2015 , em uma hora de intervalo - entre 12:30 e 13:30. O material fornecido pelas filmagens possibilitou a observação dos comportamentos de travessia individual, em grupos de pessoas desconhecidas - aqueles que se formam nas proximidades das faixas e se desfazem durante ou após a travessia, e pessoas acompanhadas - identificadas por duas ou mais pessoas que caminham juntas antes, durante e após a travessia. A partir dos dados observados nesse material foram compostas as questões 4 a 6 do questionário (ver apêndice II), que visam a identificação de mudanças do perfil quando a travessia é realizada com um grupo de pessoas desconhecidas e as questões 7 a 10, que testam as mudanças do perfil individual durante a travessia acompanhada de uma pessoa conhecida.

As entrevistas, realizadas com as pessoas logo após a realização da travessia, auxiliaram na elaboração dos construtos investigativos do ambiente de travessia, abordando características comuns a faixas de pedestres não semaforizadas, independente das características das vias 
onde estão implantadas, como força da pintura, sinalização por placas e conhecimento da velocidade dos veículos. Um fator que dificultou a aplicação das entrevistas foi a falta disponibilidade dos pedestres em responder as questões perguntadas, mostrando impaciência ou abandonando a entrevista antes do seu término. Assim sendo, não foram computados os valores das entrevistas por não consolidarem uma amostra consistente.

A Tabela 4.3 apresenta um resumo das pesquisas observacionais realizadas para embasar a primeira parte do questionário, que busca identificar o perfil do pedestre segundo os critérios previstos pelo modelo conceitual de conformidade de travessia. A formulação das questões que constituem essa fase de investigação do perfil foi amparada nas ações dos pedestres observadas, durante a travessia na faixa, nessas três pesquisas.

Tabela 4.3 - Resumo das pesquisas observacionais utilizadas para compor as questões propostas

Essa parte inicial do questionário, que busca indicar o perfil de comportamento predominante do pedestre na região pesquisada, é a principal proposta do método. Caso as questões elaboradas se mostrem eficientes no que se propõem, elas podem ser utilizadas de forma direta, como neste trabalho, em que o pedestre responde o questionário e escolhe, de acordo com a opinião própria, as alternativas que mais representam o seu comportamento, ou de forma indireta, como critérios de checagem do comportamento observado in loco ou registrado em filmes. 


\subsubsection{Uso das faixas no local pesquisado}

O questionário apresenta na questão 10 uma imagem de satélite da região onde a pesquisa será aplicada, indicando as faixas de pedestre não semaforizadas nas imediações do local. Aqui o respondente fará a escolha da faixa que mais se adequa ao cenário de travessia imaginado no início das perguntas. A finalidade desta indagação é conhecer as faixas mais citadas pelos respondentes, pois esse dado pode indicar os lugares mais utilizados para a travessia e esta informação pode ser bastante útil em situações que se pretende testar possíveis intervenções no ambiente de travessia.

\subsubsection{Parte II - Comportamento em relação a travessia na faixa}

Após a definição do perfil do pedestre respondente, alguns construtos da TCP são investigados. Essa parte do questionário fechado segue o roteiro de atividades descrito por (FISHBEIN e AJZEN, 2010), que propõem que antes do início do trabalho de confecção do questionário, o comportamento a ser investigado deve ser claramente definido nos termos de sua meta, ação, contexto e elementos de tempo. Desta forma, foi investigado o comportamento do pedestre ao: Atravessar a rua (meta) de forma assertiva e atenta (ação) durante a travessia (tempo), na faixa sinalizada para pedestres (contexto).

\subsubsection{Especificação da população de interesse para a pesquisa.}

A população de interesse para a pesquisa são as pessoas que se deslocam a pé, em uma determinada região de uma cidade, bairro ou instituição, possíveis de serem contatadas para receber o questionário de pesquisa no seu endereço eletrônico (e-mail) - forma mais ágil de preenchimento. Pretende-se aplicar o questionário, em formato digital, livremente por um período de tempo a ser determinado ou até que a amostra necessária seja coletada, utilizando os endereços eletrônicos disponíveis para criar uma mala direta para a população de interesse. Um número mínimo de respostas válidas será definido posteriormente, para possibilitar a análise estatística dos dados.

\subsubsection{Formulação de medidas investigativas diretas}

Nesta parte foram formulados itens para acessar os construtos das teorias comportamentais: (i) a atitude em relação ao comportamento investigado; (ii) a intenção de desempenhar tal comportamento; (iii) comportamentos habituais e (iv) percepção de controle 
comportamental - todos a serem investigados através de uma escala de sete pontos entre conceitos bipolares.

Foi utilizada uma técnica de diferencial semântico para medir os construtos relacionados a atitude, normas sociais, percepção de controle comportamental e intenção. Esta técnica de mensuração tem grande utilidade na pesquisa psicológica contemporânea e é muito utilizada na Teoria do Comportamento Planejado (TORRES et al., 2011). As escalas que abordam conceitos bipolares, classificados em 7 pontos, para investigar construtos da TCP, foram utilizadas por Velloso (2014) no estudo do comportamento de condutores em relação ao respeito à velocidade.

As questões, pertinentes a esta etapa do questionário, apresentaram uma formulação apresentando os conceitos bipolares conforme demonstra a questão exemplificada a seguir:

Para mim, contribuir com uma pesquisa sobre a travessia na faixa de pedestres é:

$$
\begin{array}{lllllllll} 
& 1 & 2 & 3 & 4 & 5 & 6 & 7 & \\
\text { Positivo } & \bigcirc & \bigcirc & \bigcirc & \bigcirc & \bigcirc & \bigcirc & \text { Negativo }
\end{array}
$$

Marque:

$1=$ se você considera muito positivo

$2=$ se você considera positivo

3 = se você não tem certeza se é positivo

4 = se você não tem uma opinião formada a respeito

$5=$ se você não tem certeza se é negativo

$6=$ se você considera negativo

$7=$ se você considera muito negativo

Os construtos baseados nos utilizados na pesquisa de Bamberg et al (2003) foram investigados de forma detalhada pelas questões descritas abaixo.

i) Atitudes em ralação ao comportamento foram avaliadas por meio dos dois itens seguintes: "Utilizar a faixa de pedestres da próxima vez que eu for atravessar a rua é...”: (questão 12) segundo a adequabilidade, escala: "adequado - inadequado"; (questão 13) segundo a agradabilidade, escala: “desagradável - agradável". 
ii) Os dois itens que investigam a norma subjetiva foram formulados como se segue: (questão 14) "A maioria das pessoas que são importantes para mim apoiaria que eu atravessasse na faixa" e (questão 15) "A maioria das pessoas que são importantes para mim pensa que eu deveria atravessar na faixa”. Cada uma dessas questões foi seguida por uma escala com os pontos terminais marcados por "provável improvável”.

iii) Para avaliar a percepção de controle comportamental, os entrevistados responderam a dois itens da seguinte forma: (questão 16) "Para mim atravessar na faixa para chegar ao meu trabalho ou local de estudo, da próxima vez seria", escala "fácil difícil"e (questão 17) "Minha liberdade de atravessar na faixa para chegar ao meu trabalho, ou local de estudo, na próxima vez é" "alta - baixa".

iv) Os participantes também responderam às seguintes questões sobre intenção: (questão 18) "A minha intenção de atravessar na faixa para chegar ao meu trabalho, ou local de estudo, na próxima vez é”, escala: “forte - fraca" e (questão 19) "Tenho a intenção de atravessar na faixa na próxima vez que for ao meu trabalho, ou local de estudo", escala: "provável - improvável".

A importância desta parte está na possibilidade de relacionar as características do comportamento do pedestre com suas intenções, pela investigação das suas atitudes, crenças pessoais e percepção de controle comportamental. Vale esclarecer, conforme apresenta a Figura 4.4 no item 4.2.2, que os construtos investigados por esta etapa do questionário precedem a intenção de desempenhar o comportamento de realizar a travessia na faixa. Como o questionário, e todo o método, é aplicável somente ao pedestre que realiza a travessia na faixa a investigação estes construtos serão avaliados com cuidado, para tentar identificar se algum deles apresentam maior influência do que outro no comportamento investigado.

\subsubsection{Parte III - Histórico de utilização da faixa}

Além de avaliar os preditores na teoria do comportamento planejado, o questionário também perguntou sobre o comportamento passado dos entrevistados, pedindo-lhes para indicar fatos 
da sua história que contribuíram para que ele realize as travessias na faixa de pedestre. Esses fatos históricos são apresentados na questão 20 do questionário (apêndice II).

Os itens relativos à investigação do histórico de utilização da faixa, que serviriam de complemento à sentença "Eu atravesso a rua na faixa de pedestres..." foram:

i) Desde criança, fui educado para atravessar na faixa

ii) Depois de um acidente (atropelamento) envolvendo a mim ou pessoas conhecidas

iii) Depois de ser convencido por uma campanha educativa

iv) Depois de morar em um lugar onde motoristas e pedestres respeitam a faixa

v) Quando estou próximo ao meu local de trabalho e/ou estudo

vi) Quando estou próximo do local onde moro

vii) Quando me preocupo com a opinião das pessoas que estão próximas a mim

As alternativas de resposta foram estabelecidas por uma escala Likert de 5 pontos com as possíveis respostas: discordo totalmente; discordo; não discordo nem concordo; concordo e concordo totalmente. A finalidade dessa questão é tentar investigar a relação entre o histórico de utilização da faixa pelo respondente e o comportamento identificado na primeira etapa.

\subsubsection{Parte IV - Ambiente de travessia}

A parte quatro do questionário também apresenta (questão 21) alguns fatores fixos e variáveis do ambiente de travessia que influenciam, além da segurança em si - que não é diretamente abordada, o sentimento de conforto ao atravessar a rua. A percepção das opiniões dos entrevistados da pesquisa relatada no passo 3 da Tabela 4.3 (item 4.4.1) que completaram a entrevista até o final, juntamente com dados das referências literárias, foram utilizados na composição dos itens avaliados, que correspondem às preferências de utilização da faixa.

Os itens relativos ao conhecimento das preferências de utilização da faixa, que serviriam de complemento à sentença "Eu me sinto confortável para atravessar na faixa quando..." foram:

i) A pintura da faixa está em bom estado de conservação

ii) As placas de sinalização estão em bom estado de conservação e visibilidade

iii) Atravesso em um local onde os motoristas podem me ver

iv) Atravesso em um local onde tenho uma boa visibilidade dos veículos

v) Existem carros estacionados próximo à faixa 
vi) A faixa está em local congestionado

vii) Trafegam carros e motos no local

viii) Trafegam ônibus e caminhões

ix) Atravesso em locais com ciclo faixas ou ciclovias

x) Passam poucos veículos pelo local

xi) Existem dispositivos de controle de velocidade dos veículos próximos ao local

xii) É dia

xiii) É noite

Estes itens permitem avaliar o complemento da sentença também por uma escala Likert de 5 pontos com as mesmas possíveis respostas da questão anterior: discordo totalmente; discordo; não discordo nem concordo; concordo e concordo totalmente. A finalidade dessa questão é tentar verificar as condições ambientais fixas e variáveis que permitam uma travessia em condições de conforto. A identificação das preferências de utilização da faixa pelos respondentes, pode direcionar intervenções no ambiente de travessia, buscando garantir o bem-estar do pedestre.

\subsubsection{Parte V - Hábitos de Transporte}

Nesta parte do questionário serão coletados dados sobre o comportamento de andar a pé, a sua frequência e modos de transporte complementares. O conceito de hábito aqui adotado remete aos significados atribuídos à palavra pelos dicionários de língua portuguesa: costume; maneira de se comportar; ação que se repete com frequência e regularidade; comportamento que alguém aprende e repete frequentemente.

A questão 22 busca identificar os hábitos de transporte e mobilidade do respondente, perguntando sobre o meio de transporte mais utilizado por ele nos deslocamentos gerais. As alternativas de resposta dadas foram: caminhar, bicicleta, transporte público, moto, carro (motorista ou passageiro) e taxi ou outro tipo de transporte fretado. Na questão 23 foi perguntado sobre o hábito de caminhar: "Em média, quantas vezes na semana você vai e volta andando para um lugar (ir almoçar, ao mercado, à farmácia, academia...)?”, a resposta pôde ser escolhida em uma escala de frequência: menos de 1 vez por semana; até 2 vezes por semana; de 3 a 5 vezes na semana; de 6 a 7 dias da semana e mais de 7 vezes na semana. A questão 24 indagou a frequência com que o respondente caminha, como única forma de 
transporte, para realizar viagens rotineiras completas (trabalho, estudo, alimentação, compras e lazer) e foram dadas cinco possibilidades de resposta: nunca; raramente; às vezes; frequentemente e sempre.

O objetivo da investigação dos hábitos de transporte é tentar relacionar o perfil do pedestre com os seus hábitos rotineiros de mobilidade. Os resultados provenientes do questionário serão testados, juntamente com perfil dos respondentes, para identificar se as características de mobilidade do respondente influenciam determinados comportamentos predominantes durante a travessia em faixas sinalizadas.

Uma análise mais cuidadosa dos hábitos de transporte pode, por exemplo, sugerir que o pedestre com perfil inseguro apresenta esse comportamento por ser um usuário de automóvel na maioria de seus deslocamentos e que faz raras viagens totalmente a pé. Assim, pode-se inferir que a sua insegurança ao atravessar a rua seja uma possível consequência, também, da falta de hábito caminhar e, consequentemente, de fazer travessias em faixas não semaforizadas.

\subsubsection{Parte VI - Características Individuais}

Esta constitui a última parte do questionário, onde serão respondidas questões de aspecto sócio demográficas e histórico culturais do entrevistado. São incluídos no questionário campos específicos para o respondente declarar sexo, idade, cidade e estado em que mora, tempo de moradia nesta cidade.

Para o levantamento dos dados culturais, serão respondidas questões sobre sua escolaridade e situação atual de empregabilidade (horas de dedicação ao trabalho e aos estudos). Como o questionário deverá ser aplicado a uma região da cidade, bairro ou instituição, questões específicas de cada local podem ser incluídas como questões filtro - aquelas condicionadas a determinada resposta do entrevistado. As questões filtro ajudam a diferenciar categorias de respondentes como, por exemplo, se o questionário for aplicado em instituições de ensino é possível separar as respostas de estudantes e trabalhadores do local.

A finalidade desta parte do questionário é levantar as características individuais dos respondentes para possibilitar análises estatísticas relacionando essas características com o 
perfil do modelo conceitual definido na primeira etapa do método. Assim fica mais evidente a influência, por exemplo, da idade e do sexo, do local de moradia ou do contexto histórico cultural em relação à utilização da faixa para determinado tipo de perfil predominante. Esse conhecimento pode auxiliar na elaboração de planos voltados para os pedestres mais eficazes e focados, pois define o público alvo da campanha.

\subsection{EtAPa 4: ANÁlise dos Resultados}

Nessa etapa são realizados testes estatísticos para que, a partir dos dados obtidos nas três etapas anteriores da pesquisa concernentes à coleta de dados, sejam obtidos os resultados previstos na aplicação do método, que são:

$\checkmark$ Validação da representatividade dos modelos; e

$\checkmark$ Validação da representatividade das variáveis individuais e do ambiente de travessia.

O questionário proposto na etapa 3 do MIPP é composto por seis partes distintas, cada uma configurando um instrumento de pesquisa, cujas cinco primeiras buscam identificar construtos latentes relacionados

1. ao perfil do pedestre,

2. ao comportamento em relação a faixa de travessia,

3. ao histórico de utilização da faixa

4. ao ambiente de travessia e

5. aos hábitos de transportes.

A última parte do instrumento busca coletar as características socioculturais dos respondentes. A seguir, são especificados os tratamentos estatísticos a que serão submetidos os dados coletados pelas respostas ao questionério.

\subsubsection{Modelagem por equações estruturais}

A análise geral dos dados pretende ser tratada em vários níveis para esclarecer a influência das variáveis escolhidas no comportamento investigado. Para tal, pretende-se em primeira ordem estabelecer uma análise por estatística descritiva para depois testar a modelagem por equações estruturais. A técnica denominada Modelagem por Equações Estruturais tem se mostrado avançada, se comparada a outros métodos quantitativos aplicados à pesquisa social, devido à capacidade de articulação de variáveis implícita ao método (BOOMSMA, 2000). A 
Modelagem por Equações Estruturais (MEE), também conhecida como análise com variáveis latentes, é um método usado regularmente para representar as relações de dependência (discutivelmente "causais") em dados multivariados nas ciências comportamentais e sociais.

Geralmente, um modelo de equações estruturais é uma hipótese estatística complexa e composta. Ele consiste de duas partes principais: o modelo de avaliação, que representa um conjunto de variáveis observáveis $\boldsymbol{p}$ como vários indicadores de um conjunto menor de $\mathrm{m}$ variáveis latentes, que geralmente são fatores comuns. O caminho do modelo descreve relações de dependência, geralmente aceitas como tendo algum sentido causal entre as variáveis latentes (McDONALD, 2002). Para que um MEE possa ser construído e testado, o processo deve começar pela análise fatorial confirmatória (AFC), pois se trata de uma técnica mais simples. Também porque, na avaliação dos resultados do modelo, primeiro se deve avaliar e, eventualmente, reespecificar o modelo de mensuração, que lida com as medidas dos construtos, e somente depois, o modelo estrutural, que lida com as relações entre os construtos.

A análise fatorial utiliza dois tipos de uso exploratório que estão alinhados com os objetivos de explicação e redução dos dados. O primeiro uso, relacionado à explicação, consiste em identificar as dimensões subjacentes de um determinado domínio (por exemplo: personalidade, criatividade, inteligência) que o instrumento em questão está medindo. Neste caso, análise fatorial é levada a efeito, a fim de identificar as dimensões subjacentes que representam os construtos teóricos do instrumento (LAROS, 2004). Este procedimento é exploratório porque, presumivelmente, o investigador não tem qualquer expectativa firme $a$ priori baseada em teoria ou pesquisa anterior acerca da composição de subescalas.

Assim, a análise fatorial é utilizada para descobrir as variáveis latentes que estão subjacentes à escala. Para alcançar este fim, a análise fatorial usa a matriz de correlações ou a de covariâncias entre as variáveis mensuradas. Na teoria, essas variáveis latentes são as causas subjacentes das variáveis mensuradas. A análise fatorial produz cargas fatoriais, as quais podem ser consideradas pesos de regressão das variáveis mensuradas para predizer o construto subjacente. $\mathrm{O}$ segundo uso de análise fatorial exploratória é relacionado à redução de dados. O objetivo da redução de dados é descobrir ponderações ótimas para as variáveis mensuradas, de forma que um grande conjunto de variáveis possa ser reduzido a um conjunto menor de índices sumários que tenham máxima variabilidade e fidedignidade (LAROS, 2004). 
O tamanho correto da amostra para a execução da análise fatorial ainda é um aspecto de divergência de opiniões e controvérsias na literatura científica, principalmente no que diz respeito ao tamanho da amostra mínima. Laros (2004) apresenta em seu texto uma discussão a respeito da amostra mínima necessária para uma análise fatorial, citando os trabalhos de vários autores. Os autores citados pelo texto acima referenciado e as regras gerais de dimensionamento de uma amostra mínima para a análise fatorial foram organizados e são apresentados na Tabela 4.4.

Tabela 4.4 - Regras gerais de dimensionamento de amostra mínima para a análise fatorial. Adaptado de citações feitas por Laros (2004).

\begin{tabular}{l|l|l}
\hline \multicolumn{1}{c}{ AUTOR(ES) } & \multicolumn{1}{c}{ REGRA GERAL } & \multicolumn{1}{c}{ AMOSTRA TOTAL } \\
\hline $\begin{array}{l}\text { Crocker e } \\
\text { Algina (1986) }\end{array}$ & 10 sujeitos por variável & mínimo de 100 sujeitos \\
\hline Gorsuch (1983) & 5 participantes por variável & pelo menos 200 sujeitos \\
\hline $\begin{array}{l}\text { Guadagnoli e } \\
\text { Velicer (1988) }\end{array}$ & $\begin{array}{l}\text { Depende do tamanho das cargas } \\
\text { fatoriais obtidas }\end{array}$ & $\begin{array}{l}\text { cargas fatoriais 0,80: 50 sujeitos } \\
\text { cargas fatoriais 0,40: 300 a 400 sujeitos }\end{array}$ \\
\hline Wolins (1995) & $\begin{array}{l}\text { Não existe um tamanho de amostra mínimo para efetuar uma análise fatorial } \\
\text { com um determinado número de variáveis. }\end{array}$ \\
\hline Pasquali (1999) & Mínimo de 100 sujeitos por fator medido. \\
\hline $\begin{array}{l}\text { Comrey e Lee } \\
\text { (1992) }\end{array}$ & $\begin{array}{l}\text { Amostras de 50 como muito inferiores, de 100 como inferiores, de 200 } \\
\text { como razoáveis, de 300 como boas, de 500 como muito boas e de } 1.000 \text { ou } \\
\text { mais como excelentes. }\end{array}$ \\
\hline
\end{tabular}

Conforme o apresentado pela Tabela 4.4, os vários autores citados por Laros (2004) não convergem para uma opinião em comum sobre o tamanho mínimo de uma amostra para validar a análise fatorial. Como a pesquisa propõe alguns instrumentos de investigação compostos por construtos novos, que ainda não foram testados, foi suposta uma amostra mínima de 400 questionários respondidos. Uma amostra com tal dimensão estaria de acordo com a maioria das regras gerais apresentadas acima, sendo considerada satisfatória para o dimensionamento de uma amostra para análise fatorial. A seguir, são detalhados os procedimentos de teste a que foram submetidos os instrumentos de pesquisa e as matrizes de dados por eles compostas. 


\section{a) Fatorabilidade da matriz}

O índice de Kaiser-Meyer-Olkin (KMO), também conhecido como índice de adequação da amostra, é um teste estatístico que sugere a proporção de variância dos itens que pode ser explicada por uma variável latente. Tal índice indica quão adequada é a aplicação da Análise fatorial exploratória (AFE) para o conjunto de dados (HAIR et al., 2005). O KMO é calculado por meio do quadrado das correlações totais dividido pelo quadrado das correlações parciais, das variáveis analisadas. Seu valor pode variar de zero a um. Valores iguais ou próximos a zero indicam que a soma das correlações parciais dos itens avaliados é bastante alta em relação à soma das correlações totais. Nesses casos, possivelmente a análise fatorial será inapropriada (PASQUALI, 2012). Como regra para interpretação dos índices de KMO, valores menores que 0,5 são considerados inaceitáveis, valores entre 0,5 e 0,7 são considerados razoáveis; valores entre 0,7 e 0,8 são considerados bons; valores maiores que 0,8 e 0,9 são considerados ótimos e excelentes, respectivamente (DAMÁSIO, 2012).

O teste de esfericidade de Bartlett, por sua vez, avalia em que medida a matriz de (co)variância é similar a uma matriz-identidade. A hipótese nula, no teste de esfericidade é que a matriz de correlação é uma matriz de identidade, isso quer dizer que todas as variáveis têm uma correlação de zero. A hipótese nula tem que ser rejeitada para a análise fatorial fazer sentido (LAROS, 2004). Segundo Hair et al. (2005), esse teste avalia, também, a significância geral de todas as correlações em uma matriz de dados. Valores do teste de esfericidade de Bartlett com níveis de significância $p<0,05$ indicam que a matriz é fatorável, rejeitando a hipótese nula de que a matriz de dados é similar a uma matrizidentidade. Em geral, os resultados dos testes de KMO e de esfericidade de Bartlett tendem a ser uniformes, aceitando ou negando a possibilidade de fatoração da matriz de dados.

Os critérios de Kaiser-Meyer-Olkin (KMO) e do teste de esfericidade de Barlett foram utilizados para certificação de que a matriz do estudo era passível de fatoração. Os resultados obtidos para cada instrumento em relação ao KMO e ao Teste de Esfericidade de Barlett encontram-se relatados nos subitens relativos às partes II, III, IV e V da etapa 3 do método.

\section{b) Análise fatorial exploratória - AFE}

Análise fatorial é um dos procedimentos mais frequentemente utilizados tanto na construção, quanto na revisão e avaliação de instrumentos. A análise fatorial é particularmente útil 
quando aplicada a escalas que consistem de uma grande quantidade de itens utilizados para medir personalidade, estilos de comportamento ou atitudes. O ponto central de partida na análise fatorial é o princípio da parcimônia: um grande número de variáveis observadas pode ser explicado por um número menor de variáveis hipotéticas, não-observadas. Estas variáveis hipotéticas, também chamadas de fatores, são responsáveis pelo fato de as variáveis observadas correlacionarem entre si. Um outro uso fundamental da análise fatorial ocorre no processo da validação de instrumentos psicológicos. Neste processo, a técnica de análise fatorial é imprescindível. (LAROS, 2004).

A questão do uso da análise fatorial diz respeito ao objetivo da análise, enquanto a questão da técnica ou método refere-se aos procedimentos matemáticos e estatísticos particulares utilizados para alcançar esses objetivos. Dois tipos de uso da análise fatorial podem ser identificados: o exploratório e o confirmatório. De maneira semelhante, dois tipos de técnicas de análise fatorial podem ser distinguidos: procedimentos exploratórios e procedimentos confirmatórios. Segundo Laros (2004) a confirmação de uma estrutura fatorial hipotetizada é mais adequadamente estabelecida com as técnicas de análise fatorial confirmatória, que constitui um caso especial da técnica estatística denominada Modelagem por Equação Estrutural.

$\mathrm{Na}$ análise fatorial confirmatória é testado se a estrutura fatorial teórica se adequa aos dados observados. De maneira adicional, a análise fatorial confirmatória permite testar o ajuste relativo a modelos fatoriais concorrentes. Este tipo de análise é de grande valor no processo de revisão e refinamento de instrumentos de pesquisa. A seleção do correto número de componentes para retenção na análise fatorial é um passo crucial na construção de instrumentos e na elaboração de teorias. Em relação a esta questão, Zwick e Velicer (1986 apud Laros, 2004) afirmaram que "A determinação do número de componentes ou fatores a extrair é provavelmente a decisão mais importante que um investigador, executando análise fatorial, tomará". A ocorrência de erros nesta fase afetará a interpretação de todos os resultados subsequentes e suas estruturas fatoriais.

O critério de autovalor (também chamado de eigenvalue) maior do que 1,0 é o mais comumente utilizado, para a determinação do número de fatores de um instrumento, dado que é a opção padrão nos pacotes estatísticos como o SPSS. O autovalor corresponde à 
quantidade da variância explicada por um componente, sendo que um autovalor igual a 1,0 representa a totalidade de porcentagem da variância explicada por uma única variável. A soma da quantidade de autovalores corresponde ao número de variáveis analisadas.

O teste de scree plot tem critério baseado em um gráfico dos autovalores, em que o eixo Y representa os valores dos autovalores e o eixo $\mathrm{X}$ mostra o número sequencial dos componentes. O teste separa o 'scree' de fatores triviais do início de fatores não triviais por intermédio de uma inspeção visual do gráfico. O julgamento subjetivo está então baseado no uso de uma linha reta colocada ao longo da parte do fundo do gráfico onde os pontos formam uma linha aproximadamente reta. Os pontos acima da linha reta são associados com fatores não triviais, enquanto os pontos restantes representam os fatores triviais. Laros (2004) cita que uma outra maneira para descrever o teste de scree consiste na busca de um "cotovelo" no gráfico". Para verificar o número de fatores a serem extraídos, da matriz de cada um dos vários instrumentos do presente estudo, foi realizada análise utilizando-se uma combinação dos critérios de autovalor com o gráfico "scree plot".

Depois da extração, os fatores retidos geralmente foram rotacionados para tornar a solução fatorial mais interpretável, mantendo as propriedades matemáticas da solução iguais. O objetivo do processo de rotação é conseguir uma estrutura fatorial simples. Uma estrutura simples é alcançada quando cada variável, preferencialmente, tem uma única carga alta em um único fator. Em outras palavras, uma estrutura fatorial simples existe quando cada variável tem uma carga principal em um único fator. Os construtos idealizados nos modelos desta pesquisa foram submetidos à rotação varimax. O objetivo da rotação Varimax é maximizar a variância das cargas fatoriais para cada fator por meio do aumento das cargas altas e a diminuição das cargas baixas (LAROS, 2004). Este procedimento é a opção padrão em quase todos os pacotes estatísticos e produz uma estrutura fatorial razoavelmente simples na maioria das situações.

\section{c) Modelagem por equação estrutural - MEE}

A estatística básica utilizada para a aplicação da MEE é a matriz de covariância, cujo objetivo visa entender os padrões de correlações entre os conjuntos de varáveis e explicar, através do modelo especificado, a maior parte possível da variância. Podem ser usados vários métodos de estimação para estimar a matriz de parâmetros. Na maioria das aplicações o 
modelo de mensuração é um modelo fatorial confirmatório convencional, as variáveis latentes são apenas fatores comuns, e o erro ou termos específicos não estão correlacionadas.

A condição conhecida (com exceção de escala) é a condição de que as cargas fatoriais devem formar grupos independentes. Em um modelo de grupos independentes, cada variável observada carrega apenas um fator comum, e podemos chamá-lo de um indicador puro do fator. Muito comumente, o modelo de mensuração é um modelo de grupos independentes, ou seja, um modelo de fator no qual nenhum indicador é carregado em mais de um fator comum. Por sua vez, o modelo de caminhos, estrutura a correlação ou matriz de covariância dos fatores comuns. Esta estruturação geralmente corresponde a uma conjectura de um conjunto de relações causais. O próprio caminho do modelo também é uma hipótese composta. Ele requer tanto a especificação de um conjunto de arcos direcionados (percursos) presentes contra um ausente entre as variáveis latentes, e um conjunto de arcos atuais contra arcos ausentes não direcionados Pérola (McDONALD, 2002).

Tem sido reconhecido que todos os MEE são aproximações à realidade, e não de hipóteses que podem, eventualmente, ser verdadeiramente simplificadas. Por conseguinte, uma grande quantidade de índices foi desenvolvida como medida de ajuste da aproximação para a distribuição a partir da qual a amostra foi retirada, e é muito fácil de inventar muitos outros. Como seria de esperar, a questão da qualidade do ajuste é resolvida por diferentes investigadores de formas completamente diferentes. Grande parte dos estudos relatam os globais qui-quadrado $\left(\chi^{2}\right)$ e graus de liberdade para o modelo estrutural composto (o modelo de mensuração e o path model combinados). Como já foi notado, um modelo estrutural é um compósito de um modelo de medição e um modelo de caminho (causal). Por conseguinte, pode ser útil para separar as medidas de ajuste em, pelo menos, as partes correspondentes a estes dois componentes principais. Certamente, o principal objetivo de um estudo de MEE é dar provas de apoio para o modelo de caminho especificado. O conjunto de medidas é essencialmente subserviente a este objetivo.

A aceitabilidade de um modelo especificado é dada pelo goodness off it. O teste mais clássico é o qui-quadrado $\left(\chi^{2}\right)$. Este teste é sensível ao tamanho da amostra e, na verdade, produz uma medida da má qualidade de ajuste do modelo, uma vez que valores menores de $\chi^{2}$ mostram 
um ajuste melhor, sendo zero o ajuste perfeito. Outros índices de ajuste são apresentados na Tabela 4.5.

Tabela 4.5 - Índices de ajuste para adequação do modelo em AFC e MEE. Fonte: adaptado de McDonald (2002)

\begin{tabular}{|c|c|}
\hline ÍNDICES DE AJUSTE & DESCRIÇÃO \\
\hline$\chi^{2} / \mathrm{DF}$ & $\begin{array}{l}\text { Complementa a informação sobre o qui-quadrado, representa } \\
\text { a razão entre o qui-quadrado e os graus de liberdade. É } \\
\text { interessante que a razão seja menor que } 5 \text {. }\end{array}$ \\
\hline $\begin{array}{l}\text { NFI (NORMED FIT } \\
\text { INDEX) }\end{array}$ & $\begin{array}{l}\text { Faz a comparação entre o modelo hipotético e o modelo } \\
\text { independente. Varia entre } 0 \text { e } 1 \text {, considerando-se um bom } \\
\text { ajuste valores maiores que } 0,90 \text {. Para amostras pequenas, } \\
\text { apresenta tendência em subestimar o ajuste. }\end{array}$ \\
\hline $\begin{array}{l}\text { CFI } \\
(\text { COMPARATIVE } \\
\text { FIT INDEX) }\end{array}$ & $\begin{array}{l}\text { Interpretação idêntica ao NFI, pois se trata de uma correção } \\
\text { aplicada ao mesmo, relacionada com o tamanho da amostra. } \\
\text { Para um bom ajuste CFI e NFI devem ser maiores que } 0,90 \text {. }\end{array}$ \\
\hline $\begin{array}{l}\text { RMSEA }(\text { ROOT } \\
\text { MEAN SQUARE } \\
\text { ERROR OF } \\
\text { APROXIMATION) }\end{array}$ & $\begin{array}{l}\text { Em estruturas de covariâncias, o RMSEA é reconhecido } \\
\text { como um dos critérios mais informativos sobre MEE, pois } \\
\text { considera o erro de aproximação na população, que expressa } \\
\text { a medida de discrepância em graus de liberdade. Valores de } \\
0,01,0,05 \text { e } 0,08 \text {, convencionalmente, respectivamente } \\
\text { indicam o ajuste como excelente, bom ou razoável. }\end{array}$ \\
\hline $\begin{array}{l}\text { GFI (GOODNESSOF } \\
\text { FIT INDEX) }\end{array}$ & $\begin{array}{l}\text { Considera a quantidade de covariância e variância da matriz } \\
\text { observada, reproduzida pela matriz estimada. Espera-se } \\
\text { valores próximos a } 1,0 \text { para a indicação de ajuste do modelo. }\end{array}$ \\
\hline $\begin{array}{l}\text { TLI (TUCKER- } \\
\text { LEWIS IDEX) }\end{array}$ & $\begin{array}{l}\text { De interpretação semelhante ao NFI, inclui um ajuste para a } \\
\text { complexidade do modelo. Valores maiores que } 0,90 \mathrm{e} \\
\text { menores que } 1,00 \text { representam um bom ajuste. }\end{array}$ \\
\hline $\begin{array}{l}\text { SRMR } \\
\text { (STANDARDIZED } \\
\text { ROOT MEAN } \\
\text { SQUARE } \\
\text { RESIDUAL) }\end{array}$ & $\begin{array}{l}\text { O SRMR representa a média dos resíduos padronizados. Um } \\
\text { bom ajuste é considerado para valores mais próximos de } \\
\text { zero, que não excedam o valor } 0,05 \text {. }\end{array}$ \\
\hline
\end{tabular}

\section{d) Confiabilidade do instrumento}

A confiabilidade é o grau em que um conjunto de indicadores de uma variável latente (construto) é consistente em suas mensurações. Construto é um conceito que o pesquisador pode definir em termos teóricos, mas que não pode ser medido diretamente ou medido sem erro, apenas representado ou medido por um ou mais indicadores. O Alfa de Cronbach é um teste de confiabilidade que mede a consistência dos itens do questionário, avaliando o grau em que os itens de uma matriz estão correlacionados entre si, quanto mais próximo de 1 for o resultado, maior a confiabilidade do instrumento (PASQUALI, 2012). Os valores de $\alpha$ acima de 0,60 são considerados razoáveis. O uso de medidas de confiabilidade, como o Alfa de 
Cronbach, não garante unidimensionalidade ao questionário, mas assume que ela existe. A unidimensionalidade é uma característica de um conjunto de indicadores que tem apenas um conceito em comum (HAIR et al., 2005).

A confiabilidade (intensidade da correlação entre os itens) pode ainda ser testada mediante a eliminação de itens do questionário. Se com a eliminação de um item o Coeficiente $\alpha$ aumentar, pode-se assumir que esse item não é altamente correlacionado com os outros itens da escala. Por outro lado, se o $\alpha$ diminuir, pode ser assumido que esse item é altamente correlacionado com os outros itens da escala. Assim, o Alfa de Cronbach determina se a escala é confiável, pois avalia como cada item reflete sua confiabilidade.

\subsubsection{Modelos formais probit ou logit}

A econometria contemporânea, segundo Greene (1993), oferece aos pesquisadores uma notável variedade de métodos de estimação, que vão desde as técnicas baseadas em verossimilhança bem parametrizados numa extremidade para métodos não paramétricos finamente estabelecidos, que assumem pouco mais do que a mera associação entre variáveis, e uma abundante variedade entre elas. Mesmo o investigador experiente poderia ser perdoado por se perguntar como eles devem escolher a partir desta extensa variedade de modelos.

Como uma proposição geral, a progressão de estimativas de integral para semi-paramétrico e para não-paramétrico relaxa as hipóteses fortes, mas à custa de enfraquecer as conclusões que podem ser extraídas a partir dos dados. Tanto quanto em qualquer outro lugar, isso está claro na análise dos modelos de escolha discreta, que fornecem uma das literaturas mais ativas no campo. O modelo formal probit ou logit permite a estimativa de probabilidades, efeitos marginais e uma série de resultados auxiliares, mas ao custo de impor a distribuição normal ou logística dos dados. Estimadores semi-paramétricos e não paramétricos permitem relaxar a restrição, mas muitas vezes fornecem, em troca, apenas intervalos de probabilidades que, em muitos casos, exclui a estimativa de probabilidades ou efeitos marginais úteis, mas tem a virtude da robustez nas conclusões, no entanto (GREENE, 1993).

Existem vários estudos sobre comportamento humano que fazem uso de abordagens estatísticas para o teste de determinadas hipóteses. Nesse estudo, em particular, a 
preocupação central refere-se ao comportamento do pedestre e seu comportamento ao escolher utilizar a faixa de pedestres. Nesta abordagem, a maior dificuldade refere-se a questão da variável latente. Variável latente é uma variável que não pode ter seu valor diretamente observado. Por exemplo, sabe-se que abaixo de determinado salário determinado trabalhador não aceita trabalhar, chama-se isso de salário de reserva. Salário de reserva é uma variável latente, não temos como observar qual é o salário de reserva de cada trabalhador na economia, mas podemos fazer uma inferência simples: se o indivíduo trabalha, então é porque seu salário é superior ao seu salário de reserva.

No estudo sobre o comportamento dos pedestres há um problema similar de variável latente, não é possível observar diretamente o valor que cada pedestre dá a faixa de pedestres. Contudo, podemos inferir que se o pedestre usa a faixa então é porque ela lhe proporciona um benefício (segurança, adequação a normas sociais, etc.) superior ao seu custo (deslocamento até a faixa para fazer a travessia por exemplo). Em situações onde a variável latente é a variável de interesse, uma modelagem adequada é a modelagem probabilística. Nessa modelagem escolhe-se um modelo estrutural que possibilita a estimativa por um modelo reduzido. Para testar as hipóteses do modelo estrutural será testada também a metodologia Probit proposta por Goldberg (1991) e Greene (1993).

\subsection{CONSIDERAÇÕES SOBRE O CAPÍTULO}

Os estudos para o desenvolvimento do modelo conceitual de travessia, apresentado na Etapa I, possibilitaram a organização dos critérios de observação dos movimentos dos pedestres focando três comportamentos: a aproximação da faixa, a velocidade de travessia e o foco de atenção durante a travessia. A ordenação desses comportamentos, embasados por estudos de conformidade de travessia, apresentados no item 3.2, permitiu a definição do modelo conceitual.

O modelo de conformidade de travessia, especificado na primeira etapa (Figura 4.5), não constitui um modelo matemático a ser comprovado pelos dados da pesquisa proposta na terceira etapa, e sim um modelo de orientação, que busca propor diretrizes de observação do comportamento do pedestre em travessia, utilizando faixas não semaforizadas. Os critérios definidos pelo modelo foram testados durante as pesquisas de observação, envolvendo 
filmagens, e confirmaram a capacidade de caracterização dos comportamentos mais comuns dos pedestres, abordando os três momentos de conformidade - espacial, temporal e com o sistema de trânsito, que descrevem os três comportamentos de foco para a pesquisa, descritos acima.

A segunda etapa de composição do MIPP abordou o levantamento das crenças salientes que, através das respostas de um questionário aberto, auxiliou a adaptação dos construtos da TCP, a partir dos construtos apresentados por Bamberg et al (2003). A terceira etapa do método é constituída por um questionário, composto por seis instrumentos de pesquisa diferentes:

i. Identificação do perfil do pedestre

ii. Comportamento em relação à faixa

iii. Histórico em relação à utilização da faixa

iv. Ambiente de travessia

v. Hábitos de transporte

vi. Caraterísticas individuais

Cada um desses instrumentos se propõe a investigar fatores que podem auxiliar a caracterização do comportamento dos pedestres durante a travessia. A aplicação do método e a análise dos resultados obtidos são apresentadas no próximo capítulo. 


\section{APLICAÇÃO DO MÉTODO E ANÁLISE DE RESULTADOS}

Os fenômenos constituem o mundo como nós o experimentamos, ao contrário do mundo como existe independentemente de nossas experiências. Os seres humanos não podem saber da essência das coisas-em-si, mas saber apenas das coisas segundo nossos esquemas mentais que nos permitem apreender a experiência. A ciência deve, portanto, preocupar-se em compreender o próprio processo da experiência.

Kant (1787)

O método descrito no capítulo 4 foi completamente testado na cidade de Brasília, no Distrito Federal. A escolha da cidade para aplicação do método deve-se ao fato de que Brasília é a única dentre as grandes cidades brasileiras que atingiu a meta de fazer com que a população utilize corretamente a faixa de pedestre, incentivando o pedestre a reconhecer o seu espaço na via e os condutores de veículos a respeitarem esse espaço. Isso ocorreu graças aos esforços conjuntos da sociedade, dos órgãos normativos e fiscalizadores que trabalharam juntos para mudar a realidade existente.

Brasília nos anos de 1995 e 1996 era uma das cidades mais violentas no trânsito, não só pelo grande número de acidentes e vítimas fatais, mas também pela violência dos acidentes e pelo alto índice de pedestres atropelados. O número de atropelamentos nesses anos representava 49,8\% do número total de acidentes, e 47,3\% era proporção de acidentes com morte em todo Distrito Federal (LÉ SÉNÉCHAL-MACHADO e TODOROV, 2007). Esses números revelavam a situação grave em que se encontrava a relação entre condutores e pedestres em Brasília, uma cidade planejada para a rápida e fácil circulação de veículos motorizados, com pistas largas e longas, que favorecem o abuso da velocidade e dificultam a travessia das ruas pelas pessoas. Porém, desde o ano de 1997, tem sido possível observar o respeito à faixa de pedestre, tanto pelos próprios pedestres quanto dos motoristas.

O cumprimento da lei aconteceu a partir de uma mobilização social que promoveu a união entre a mídia, o governo e a sociedade civil brasiliense em prol de um mesmo objetivo: a Paz no Trânsito. Esses esforços conjuntos, juntamente com uma fiscalização ostensiva por parte dos órgãos normativos, proporcionaram a mudança de uma prática cultural da população (LÉ SÉNÉCHAL-MACHADO e TODOROV, 2007), que pode ser observada ainda hoje. Após 19 anos do reconhecimento da importância de se respeitar o espaço de 
travessia dos pedestres, a política pública adotada em Brasília continua sendo um exemplo a ser seguido.

O ponto fundamental da implantação da política de Paz no Trânsito em Brasília está no fato de demostrar que é possível modificar as crenças pessoais dos indivíduos, refletindo na modificação de um comportamento social, através do entendimento da relação de interação pessoa - espaço físico que a mobilidade urbana exige. Como diversos fatores exercem influência nesta relação, este trabalho se concentra no estudo da relação pedestre - faixa de travessia na esperança de contribuir com o enfoque comportamental nos estudos dos deslocamentos dos pedestres. É fato que este trabalho não pretende criar meios de repetir a implantação de uma política tal qual aconteceu em Brasília. A pesquisa aqui relatada objetiva tentar compreender o comportamento do pedestre que transita em um local onde o respeito a faixa acontece há 19 anos, configurando assim o lugar adequado para investigar o comportamento do pedestre durante a travessia na faixa não semaforizada.

No texto de apresentação do método (item 4.1) fica esclarecido que, ao tentar compreender o comportamento do pedestre durante a travessia, essa pesquisa visa, principalmente a indicação de um perfil predominante do pedestre, de acordo com o modelo conceitual da conformidade de travessia. O MIPP se propõe a caracterizar o pedestre, segundo o seu comportamento, em inseguro, hesitante, distraído e atento, de acordo com os critérios sequenciais das conformidades espacial, temporal e com o sistema de trânsito. É de conhecimento comum que na maior parte das grandes cidades brasileiras a faixa de pedestre não é reconhecida e nem respeitada por pedestres e motoristas. Assim, a aplicação do questionário em Brasília se justifica principalmente pelo fato de a cidade representar o local onde é possível investigar o comportamento do pedestre que se enquadra no perfil "atento" - aquele que cumpre todas as conformidades de travessia determinadas pelo modelo conceitual do método (Figura 4.5), pois se trata de um local onde os motoristas respeitam a faixa, fator imprescindível para que o pedestre se sinta seguro e confortável em fazer a travessia nesse local.

A mudança na prática cultural em relação à faixa de pedestre em Brasília aconteceu há 19 anos passados. Isso remete ao pensamento de que uma geração, hoje em idade adulta, cresceu com o entendimento de que o melhor local para realizar a travessia é na faixa de pedestre, 
certamente em virtude das normas sociais construídas pela mudança cultural ocorrida. Mas Brasília, capital federal, centro financeiro, administrativo e executivo do país, é uma cidade dinâmica, que atrai constantemente pessoas de várias cidades brasileiras e de outros países, formando uma população heterogênea e em constantes movimentos de migração. Apesar desse dinamismo e do grande número de pessoas que constantemente chegam e se tornam moradores da cidade, o respeito à faixa persiste. Esse fato merece uma atenção especial, tanto no resgate do protocolo de trabalho que proporcionou a mudança na prática cultural em relação à faixa - que não representa o foco deste trabalho, quanto pela possibilidade de investigar a interação dessas pessoas, quando pedestres, com os condutores no sistema de trânsito.

Ao ser realizado em um local distinto de Brasília, o teste inicial do modelo poderia mascarar resultados, pois se o espaço do pedestre não representar uma conquista real de direito de uso, a investigação do comportamento durante a travessia não poderia ser parametrizada, como aconteceu a partir dos resultados das observações que embasaram a elaboração do método. Mas, após a investigação de teste inicial, os próprios resultados obtidos pelo método podem parametrizar novas investigações, feitas em locais onde a faixa ainda não atingiu a realidade de sua regulamentação.

\subsection{APLiCAÇÃo dO MÉTODO}

O MIPP, como descreve o início do capítulo 4, se propõe a investigar e indicar o perfil predominante do pedestre através da aplicação de um questionário em locais que concentrem uma grande quantidade de pessoas em atividades rotineiras, como trabalho e estudo. Brasília, além da conquista do respeito à faixa, também abriga um importante campus universitário, constituído por 26 institutos e faculdades e 21 centros de pesquisa. O Campus Darcy Ribeiro, da Universidade de Brasília - UnB, ocupa uma grande área e é um grande polo atrativo de viagens. Os principais acessos rodoviários acontecem pelas vias L2 e L3, que possuem radares controladores de velocidade para veículos e muitas faixas de travessia para pedestres.

O sistema de circulação interno do campus também abriga várias vias, com linhas de transporte público interna e externas, ciclovias e muitas faixas de pedestres. A Figura 5.1 traz uma imagem de satélite do campus pesquisado, com alguns pontos de referência, a 
localização e identificação numérica das 22 faixas não semaforizadas presentes nas imediações - a mesma imagem foi utilizada para identificação da faixa referência para as respostas da parte I, questão 10 do questionário. Assim, tendo a cidade de Brasília como contexto de fundo para a experiência, o teste inicial do MIPP foi realizado no Campus Darcy Ribeiro, da Universidade de Brasília - UnB.

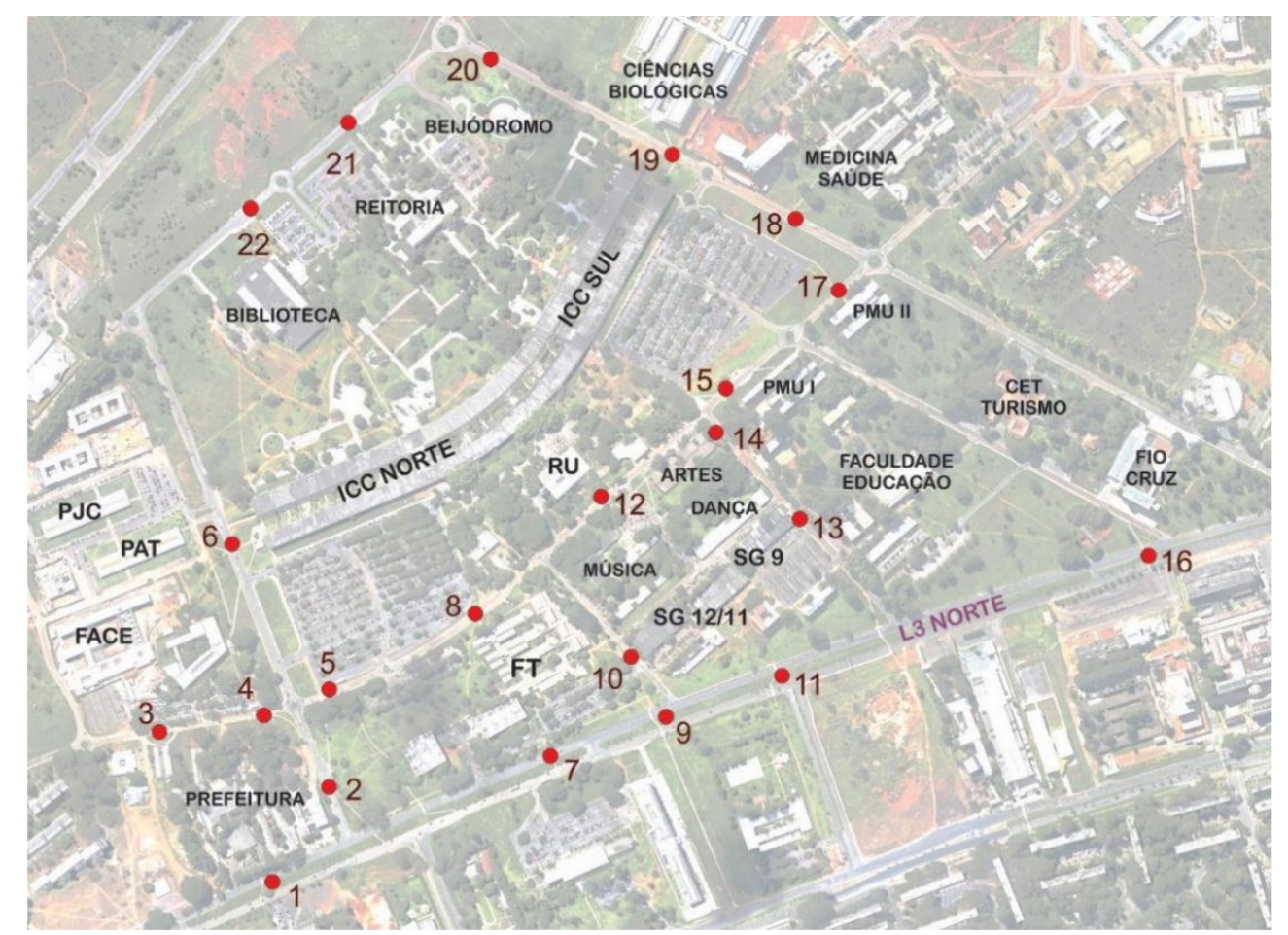

Figura 5.1 - Campus Darcy Ribeiro com a indicação numerada das faixas de pedestre não semaforizadas e de alguns pontos referenciais.

O questionário foi veiculado ao público da UnB de duas formas. Uma delas foi através envio de um link eletrônico do questionário, elaborado na plataforma de formulários da Google e distribuído por mala direta, via correio eletrônico para endereços cadastrados em um banco de dados da UnB. Apesar da lista de mala direta conter 1043 endereços eletrônicos, o retorno de respostas somou apensa 157 questionários válidos. Uma forma de acrescentar um número maior de questionários respondidos à amostra de pesquisa foi a aplicação do formulário impresso diretamente aos alunos, dentro das salas de aula. Essa segunda forma de veiculação adicionou mais 251 formulários respondidos.

Ao todo foram analisados 408 questionários respondidos, validados por indivíduos e suas respectivas posturas ao fazer uso das faixas de pedestres. A estatística descritiva, apesar de sua análise simples, muito revelou do comportamento investigado, fundamentando 
principalmente a indicação do perfil predominante. A modelagem, por sua vez, possibilitou a verificação das características individuais e ambientais que exercem influência na decisão do pedestre em abordar o espaço de travessia de forma assertiva. A seguir são apresentadas as análises estatísticas descritivas gerais do estudo, seguido dos resultados obtidos pela modelagem.

\subsection{CARACTERÍSTICAS INDIVIDUAIS}

A última parte do questionário da etapa 3 do método, parte VI, traz perguntas com a finalidade de caracterizar as características individuais dos respondentes. Esses resultados são aqui apresentados com a intenção de familiarizar o leitor com as características da amostra antes de discorrer sobre os resultados e o tratamento dos dados coletados. Das pessoas que frequentam o Campus Darcy Ribeiro e que responderam à pesquisa, 53,8\% são homens, a idade dos respondentes varia de 17 a 74 anos, com idade média de 29 anos. Quase a totalidade dos componentes da amostra $(91,9 \%)$ mora em Brasília e 96,3\% mora no Distrito Federal. Foi também indagado sobre o tempo de moradia na cidade, mas, não necessariamente no mesmo endereço. $46,7 \%$ dos respondentes afirmaram morar na cidade por mais de 10 anos e outros $17,2 \%$ moram na cidade por mais de 20 anos.

As perguntas sobre o nível escolaridade revelaram 48,9\% estudantes de graduação, 30,7\% estudante pós-graduação e 13,8\% com pós-graduação completa. Este alto nível de escolaridade não surpreende, pois, a pesquisa foi realizada em um campus universitário. Mas esse fato descaracteriza uma associação do comportamento a este indicador, devido à baixa variabilidade da amostra.

No quesito ocupação, 83,2\% dos participantes estuda na UnB, 46,4\% trabalham em tempo integral (mais de 20h por semana), 30,7\% estudam em tempo integral (mais de 20h) por semana e quase a metade dos respondentes $(45,3 \%)$ trabalha na Universidade de Brasília. Nos tratamentos estatísticos, realizados com os dados da amostra, e apresentados nos itens a seguir, nenhuma das características individuais se mostrou um indicador correlacionado com o comportamento do pedestre durante a travessia. 


\subsection{IDENTIFICAÇÃO DO PERFIL DO PEDESTRE}

Aqui é apresentada uma análise geral dos dados obtidos com as respostas da primeira etapa do questionário, dedicada a identificar as características do perfil do pedestre. Primeiramente, com os dados dos 408 questionários, foi realizada uma análise descritiva das conformidades que constituem o modelo conceitual do MIPP: conformidade espacial, conformidade temporal e conformidade com o sistema de trânsito. Essa análise possibilitou a visualização das mudanças de comportamento, em relação à conformidade investigada, quando o pedestre atravessa a via sozinho, com um grupo de pessoas desconhecidas e acompanhado de uma pessoa que ele considera importante nas suas relações afetivas. Após a análise das conformidades, é explicada a forma utilizada para identificar o perfil do pedestre e a indicação do perfil do pedestre predominante dentre os entrevistados.

\subsubsection{Análise da conformidade espacial}

A análise da conformidade espacial envolve a forma de aproximação do pedestre ao espaço de travessia. O comportamento do pedestre nesse instante inicial da travessia define, segundo o modelo conceitual proposto, o reconhecimento de uso daquele espaço de travessia. Se o pedestre faz o gesto com a mão (denominado "sinal de vida"), sinalizando para os condutores o desejo de realizar a travessia e reconhecendo a sua prioridade no uso daquele espaço, o seu comportamento está de acordo com a conformidade espacial. A seguir são representadas as proporções das escolhas comportamentais das questões das questões 1, 4 e 7 (Figura 5.2, Figura 5.3 e Figura 5.4), que avaliam, respectivamente, como o pedestre inicia a travessia quando está sozinho, quando está com um grupo de pessoas desconhecidas e quando está acompanhado de uma pessoa com quem tem laços afetivos.

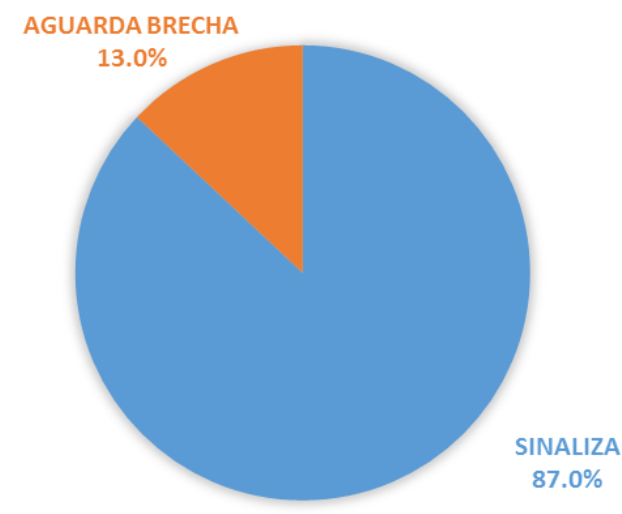

Figura 5.2 - Proporção de pedestres, atravessando sozinho, em relação a conformidade espacial. 


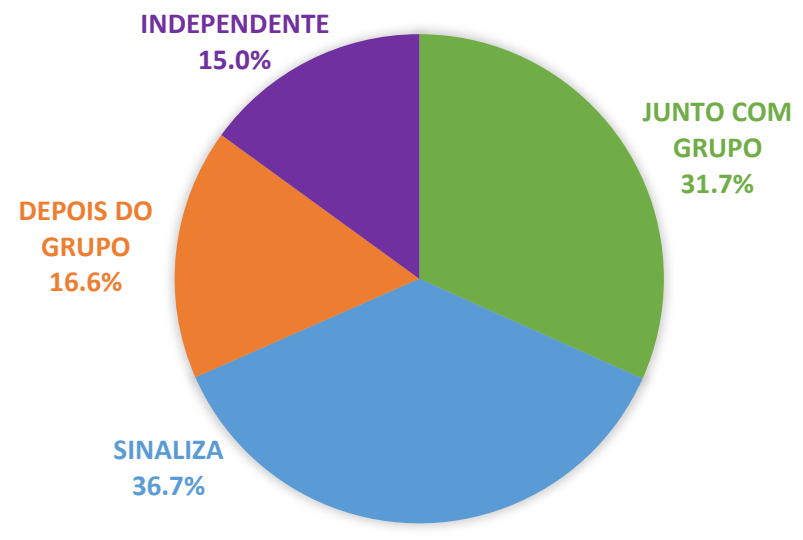

Figura 5.3 - Proporção de pedestres, atravessando com um grupo de pessoas desconhecidas, em relação a conformidade espacial.

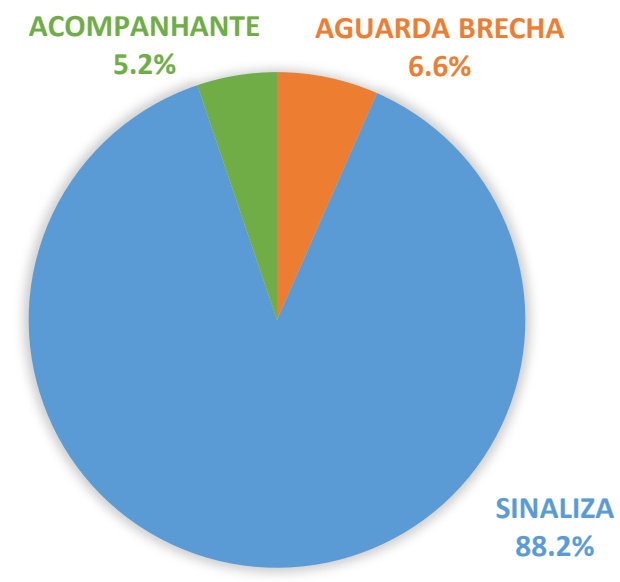

Figura 5.4 - Proporção de pedestres, atravessando acompanhado de alguém conhecido, em relação a conformidade espacial.

A Figura 5.2 apresenta a proporção de pedestres que, atravessando sozinho, faz uso do "sinal de vida". Verifica-se que $87 \%$ dos pedestres, ao atravessarem sozinhos na faixa, sinalizam para os carros indicando que querem efetuar a passagem. A implantação da política de uso da faixa em Brasília inseriu esse costume nos pedestres da cidade, que continua sendo transferido para as crianças e para os novos moradores do local, reafirmando a mudança da prática cultural descrita por Lé Sénéchal-Machado e Todorov (2007). Esse ato de indicação da travessia através da sinalização, relatado pela maior parte dos respondentes, confirmou o observado nas filmagens das pesquisas utilizadas para a elaboração do MIPP (Tabela 4.3). 
A questão 4 do questionário propõe ao respondente que ele indique o seu comportamento de travessia quando se imagina numa travessia com um grupo de pessoas desconhecidas. A Figura 5.3 apresenta a proporção de respostas a esta questão, cujas alternativas de complemento da sentença "No momento de iniciar a travessia, você se posiciona em frente à faixa de pedestres para iniciar a travessia e..." dadas foram: espera para iniciar a travessia junto com as pessoas do grupo; acena para os carros e começa a travessia; começa a atravessar logo depois que o grupo iniciou a travessia; começa a travessia independente do grupo.

Ao avaliar os dados mostrados na Figura 5.3, percebe-se claramente a influência da presença de outras pessoas no momento da travessia. Nesse novo cenário a assertividade do pedestre em acenar para sinalizar o desejo de travessia sofre forte influência do grupo. Os $87 \%$ dos pedestres que relataram sinalizar antes da travessia são reduzidos a $36,7 \%$. Os outros $63,3 \%$ dos respondentes marcaram respostas de ações dependentes do grupo. Esse comportamento é conhecido da psicologia, chamado de comportamento de rebanho ou manada. Esse comportamento acontece quando um indivíduo presume que algo é bom (ou ruim) com base no comportamento de outras pessoas, e acompanha esse comportamento (ARIELY, 2008).

Intuitivamente, no momento de travessia, o pedestre pode se sentir mais protegido e visível quando faz parte de um grupo de pessoas, mesmo permanecendo próximo a esse grupo ou o tendo como referência. Conhecer esse fato tem a importância de perceber que a norma social exerce influência no momento de travessia, conforme demonstrou o levantamento das crenças salientes, no item 4.3. Pois, caso as pessoas preferissem fazer a travessia em qualquer lugar da via, atravessando sozinhos e fora da faixa, provavelmente outros pedestres se sentiriam impelidos a realizar o mesmo comportamento. $\mathrm{O}$ fato citado pode ser facilmente percebido em qualquer cidade brasileira onde o respeito à utilização da faixa ainda não tenha sido conquistado pelos cidadãos.

A Figura 5.4 mostra os resultados dos comportamentos relatados sobre a travessia na companhia de alguém que o respondente julgue ser uma pessoa importante para ele. Nesse cenário percebemos uma proporção de atitude assertiva - sinalizando antes da travessia muito próxima da relatada na situação de travessia sozinho. Pode-se notar que na figura que, uma parte da porcentagem de pedestres que relataram aguardar uma brecha para iniciar a travessia, na situação de estar acompanhado por uma pessoa conhecida, segue o comportamento dessa pessoa. 
A questão 10 do questionário, apresentada no formulário logo após as questões que tratavam do cenário em que o pedestre se imagina em uma travessia com uma pessoa que ele considere importante, perguntava que pessoa ele havia imaginado durante suas respostas. A apresenta a proporção de pessoas escolhidas entre as alternativas dadas na questão.

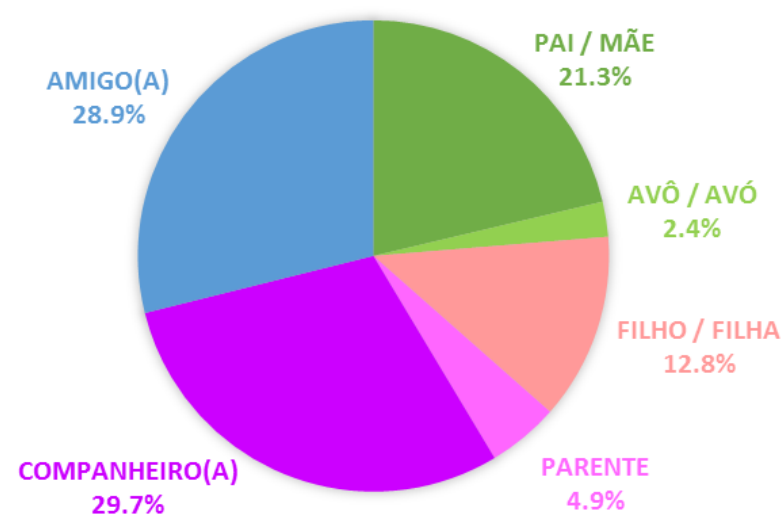

Figura 5.5 - Proporção das pessoas escolhidas pelos respondentes ao se imaginar atravessando com alguém que considere importante.

A análise da conformidade espacial, definida pelo modelo conceitual do método, mostrou que a maioria dos pedestres que fizeram parte da amostra de pesquisa fazem a travessia dentro desta conformidade. Também mostrou que o comportamento do pedestre no início da travessia sofre influência tanto de grupos de pessoas desconhecidas, quanto da presença de pessoas conhecidas. Sendo que, no último caso, a assertividade de acenar antes da travessia teve um sutil acréscimo em sua proporção de 1,2\%. Ambos os fatos sugerem uma relação de proteção entre as pessoas - o pedestre se sente protegido na travessia em grupo, tanto que modifica suas ações em situações assim, se tornando mais passivo em relação ao grupo, e se sente no dever de proteger uma pessoa importante, retomando a assertividade ao abordar a faixa no início da travessia.

\subsubsection{Análise da conformidade temporal}

A conformidade temporal, neste estudo, trata do tempo de travessia, tendo como discriminante investigativo a variação da velocidade de caminhada enquanto o pedestre atravessa na faixa. As figuras a seguir (Figura 5.6, Figura 5.7 e Figura 5.8) apresentam as proporções das escolhas comportamentais das questões das questões 2,5 e 8 , que avaliam a variação da velocidade durante a travessia, respectivamente, quando está sozinho, quando 
está com um grupo de pessoas desconhecidas e quando está acompanhado de uma pessoa com quem tem laços afetivos.

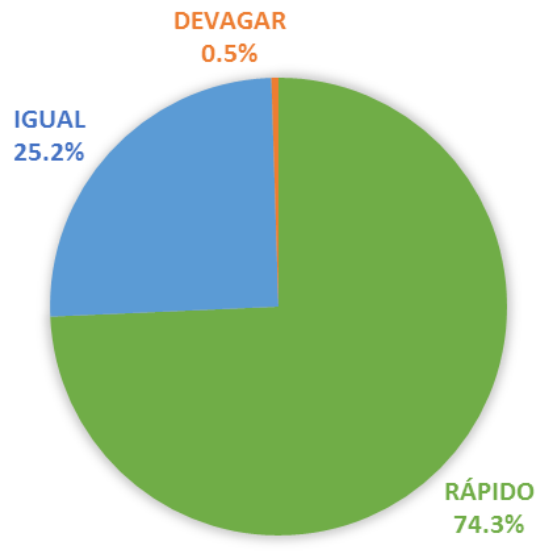

Figura 5.6 - Proporção de pedestres, atravessando sozinho, em relação a conformidade temporal.

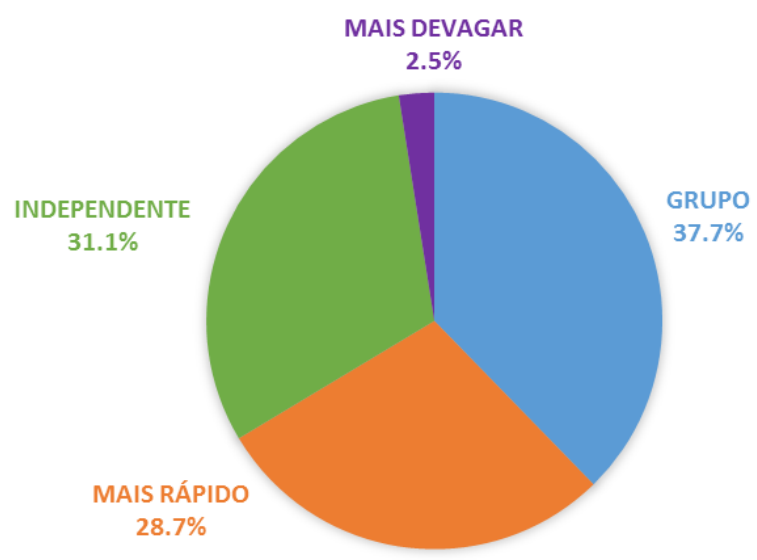

Figura 5.7 - Proporção de pedestres, atravessando com um grupo de pessoas desconhecidas, em relação a conformidade temporal.

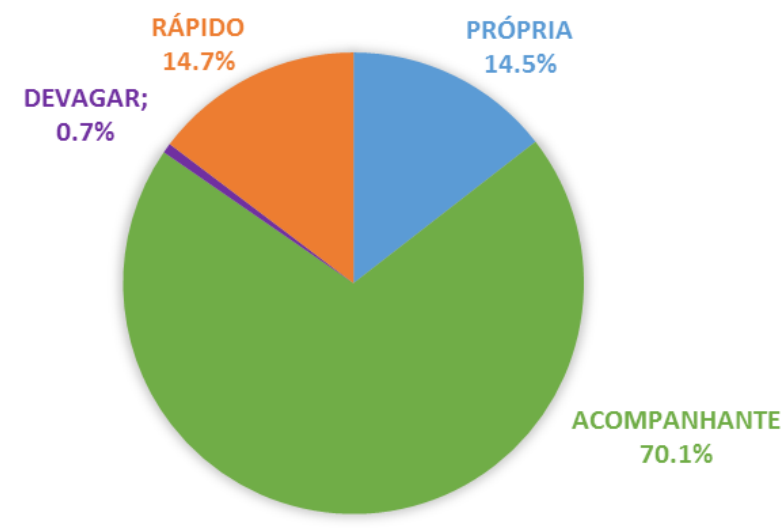

Figura 5.8 - Proporção de pedestres, atravessando acompanhado de alguém conhecido, em relação a conformidade temporal. 
O conhecimento desta variação de velocidade pode indicar, de forma indireta, desconforto ou insegurança de compartilhar a via com veículos no momento da travessia, reduzindo o tempo de permanência no local, utilizando um tempo menor que o necessário para que o cruzamento ocorra. A Figura 5.6 mostra que praticamente dois terços da amostra declaram que fazem a travessia "mais rápido do que costumam caminhar". Quando atravessa com um grupo de pessoas desconhecidas, $37,7 \%$ dos respondentes relataram se adequar à velocidade do grupo e $28,7 \%$ se afastam do grupo, rapidamente, após o início da travessia. Ao fazer a travessia acompanhado, a maior parte dos respondentes $(70,1 \%)$ afirmaram caminhar na mesma velocidade da pessoa que o acompanha, durante a travessia. Nas três situações analisadas, uma quantidade ínfima de respondentes atravessa a via em uma velocidade maior do que a velocidade normal de caminhada.

\subsubsection{Análise da conformidade com o sistema de trânsito}

O conceito de conformidade com o sistema de trânsito, apresentado no item 4.2.1, tem a finalidade de investigar o nível de consciência do pedestre, em relação à sua atuação como agente do sistema de trânsito, quando realiza uma travessia. A análise da conformidade com o sistema de trânsito busca identificar o foco de atenção do pedestre durante a travessia. As questões 3, 6 e 9 do questionário indagam ao respondente o que eles fazem enquanto atravessam a rua quando estão sozinhos, quando estão acompanhados por um grupo de pessoas estranhas e quando estão na companhia de uma pessoa conhecida. A Figura 5.9, a Figura 5.10 e a - Proporção de pedestres, atravessando acompanhado de alguém conhecido, em relação a conformidade com o sistema de trânsito.Figura 5.11 mostram, respectivamente, as proporções de comportamentos relatados como respostas em cada uma das três situações.

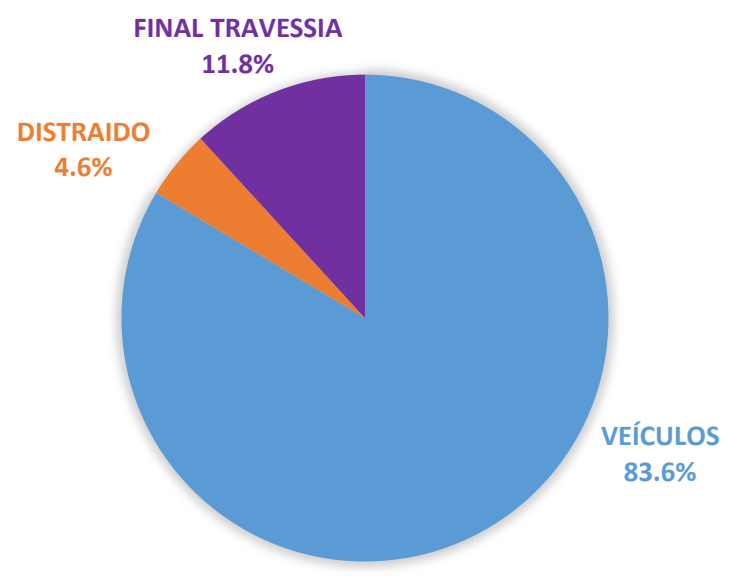

Figura 5.9 - Proporção de pedestres, atravessando sozinho, em relação a conformidade com o sistema de trânsito. 


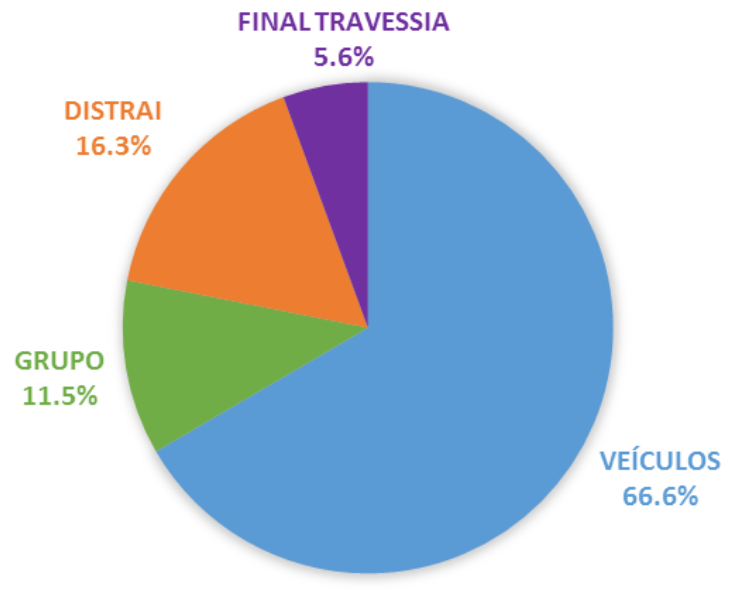

Figura 5.10 - Proporção de pedestres, atravessando com um grupo de pessoas desconhecidas, em relação a conformidade com o sistema de trânsito.

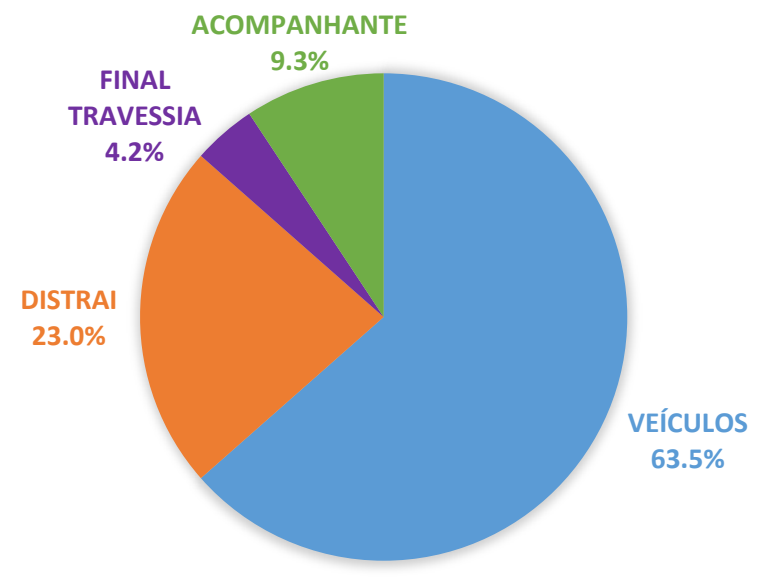

Figura 5.11 - Proporção de pedestres, atravessando acompanhado de alguém conhecido, em relação a conformidade com o sistema de trânsito.

Ao observar as figuras (Figura 5.9, Figura 5.10, Figura 5.11) pode-se perceber que quando o pedestre faz a travessia acompanhado, o seu nível de atenção ao fluxo de veículos diminui. 83,6\% dos respondentes declaram ficar atento ao movimento de veículos quando está sozinho, 66,6\% permanecem atentos ao tráfego quando estão com um grupo de desconhecidos e 63,3\% resistem a alguma distração quando estão acompanhados de uma pessoa conhecida. De forma proporcional o nível de distração aumenta, de 4,6\% do pedestre sozinho, a 16,3\% quando atravessando em grupo e 23,0\% de distração na travessia acompanhada. 


\subsubsection{Indicação do perfil predominante}

A primeira etapa do questionário visa obter dados para identificar as características comportamentais dos pedestres, de acordo com o modelo conceitual de conformidade de travessia e, a partir dessa identificação, indicar o perfil predominante do pedestre. $\mathrm{O}$ modelo conceitual de conformidade de travessia (Figura 4.5) indica uma sequência de questões dicotômicas parametrizadas para a análise da conformidade. Essas questões verificam o comportamento do pedestre através de três critérios de análise da travessia: aproximação do espaço (faixa) no início da travessia, velocidade de caminhada e atenção durante a travessia, conforme é apresentado na Tabela 5.1. A aplicação do modelo conceitual para a identificação do comportamento que compõe o perfil do pedestre foi feita de forma eliminatória, ou seja, a análise da conformidade temporal só foi realizada para os respondentes de acordo com a conformidade espacial, e a análise da conformidade do sistema de trânsito para os respondentes de acordo com as duas conformidades anteriores.

Tabela 5.1 - Aplicação do modelo conceitual de conformidade para indicação do perfil do pedestre.

\begin{tabular}{|c|c|c|c|c|}
\hline $\begin{array}{l}\text { CONFORMIDADE } \\
\text { DE TRAVESSIA }\end{array}$ & $\begin{array}{c}\text { CRITÉRIOS DE } \\
\text { ANÁLISE }\end{array}$ & COMPORTAMENTO & SIM & NÃO \\
\hline Espacial & Aproximação & Sinaliza & 1 & 0 \\
\hline Temporal & Velocidade & Muda a velocidade & 0 & 1 \\
\hline Sistema de trânsito & Atenção & Atento aos veículos & 1 & 0 \\
\hline
\end{tabular}

A sequência de análises das conformidades para definir o perfil predominante dos pedestres foi feita apenas com as respostas das questões 1 a 3 do questionário, que investiga o comportamento do pedestre quando ele realiza a travessia sozinho. As questões 4 a 6 , que investigam o comportamento do pedestre durante a travessia com um grupo de pessoas desconhecidas, e as questões 7 a 9, que investigam o comportamento quando a travessia é feita na companhia de uma pessoa com quem o pedestre possui ligações afetivas serviram para compreender a influência dessas situações no perfil inicial de comportamento, quando o pedestre atravessa sozinho. A Figura 5.12 apresenta a proporção de cada perfil, definido pelo modelo conceitual de conformidade de travessia, considerando a amostra de 408 questionários respondidos. 


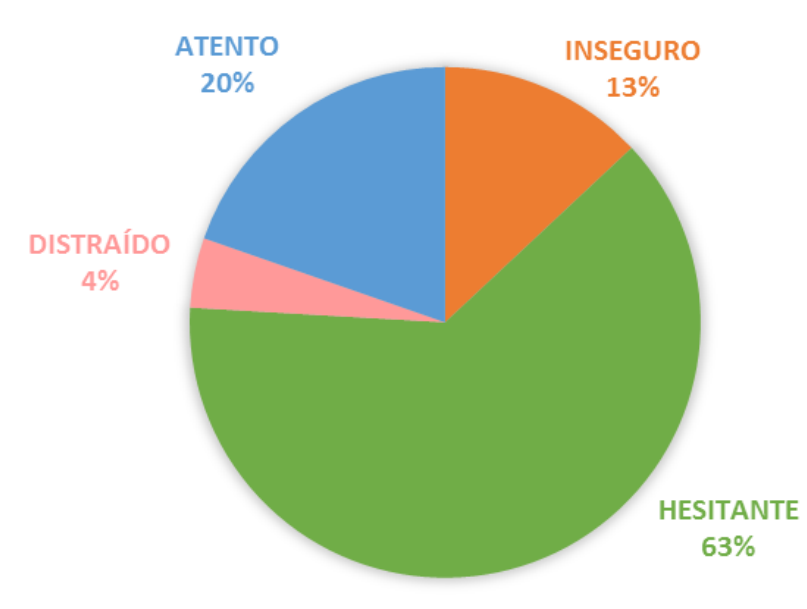

Figura 5.12 - Caracterização do perfil dos pedestres da UnB que responderam ao questionário.

A importância de conhecer o perfil do pedestre se justifica na possibilidade de elaborar estratégias de planejamento da circulação voltadas para reforçar os comportamentos positivos da população em relação à faixa de pedestres e tentar mitigar os comportamentos negativos. A Figura 5.12 mostra que a população de respondentes é representada pelo perfil "hesitante". Esse perfil é definido pelo pedestre que sinaliza antes de iniciar a travessia, mas durante a travessia caminha mais rápido que a velocidade normal de caminhada. Dos 256 respondentes que foram caracterizados como "hesitantes", 213 declararam ficar atentos ao fluxo de veículos durante a travessia.

O instrumento de identificação do perfil do pedestre mostrou estar de acordo com os comportamentos observados nas pesquisas observacionais envolvendo filmagens - etapa 2 do método. Entretanto, o número de indicadores utilizados para caracterizar os comportamentos pesquisados foi insuficiente para caracterizar um construto latente, como os perfis comportamentais especificados pelo modelo comportamental. As tentativas de análise do instrumento a respeito de fatorabilidade da matriz de dados não foram, satisfatórios. Por isso, somente foram apresentados os resultados da estatística descritiva dos dados coletados. A seguir, são apresentados os resultados dos instrumentos correspondentes às partes II, III, IV e V do questionário que compõe a etapa 3 do método. 


\subsection{FAIXAS DE TRAVESSIA MAIS UTILIZADAS NO CAMPUS DARCY RIBEIRO}

A questão 11 do questionário indaga sobre a faixa em que o pedestre se imaginou fazendo a travessia ao responder o questionário. A intenção desta pergunta está em conhecer quais faixas são mais utilizadas pelos respondentes para acessar ou circular no local onde a pesquisa foi realizada. Certamente, é uma informação que pouco contribui para o conhecimento do comportamento durante a travessia na faixa. Mas, por outro lado, o conhecimento dos locais mais utilizados para as travessias pode auxiliar no planejamento de instalações de facilidades de travessia, testes de equipamentos de iluminação ou relacionados ao conforto durante a travessia, e mesmo contagens de pedestres e localização de postos de pesquisas relativas ao tema. A Figura 5.13 apresenta as faixas mais utilizadas, em proporção, no Campus Darcy Ribeiro pelos respondentes do questionário.

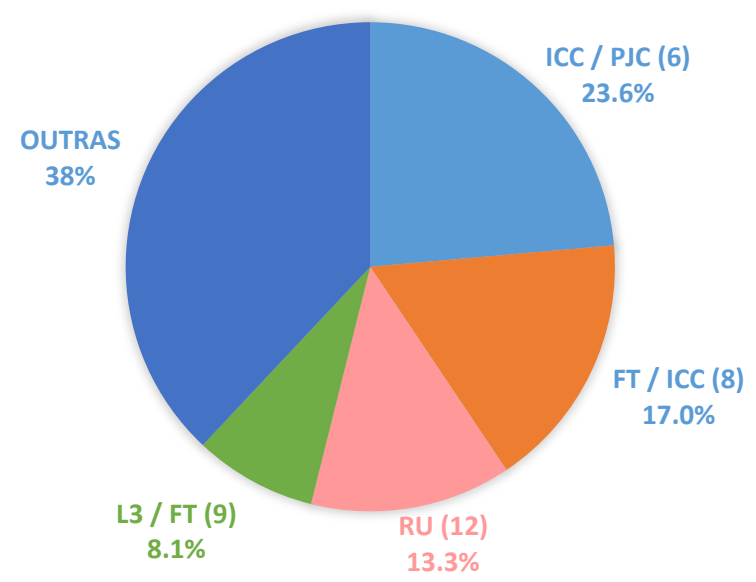

Figura 5.13 - Proporção das faixas mais utilizadas no Campus Darcy Ribeiro.

Os dados apresentam o que pode ser confirmado por qualquer frequentador desse campus da Universidade de Brasília, que se ponha a observar os fluxos de pessoas caminhando pelo local. Cerca de um quarto dos respondentes $(23,6 \%)$ se referiu à faixa que faz a travessia ligando o Instituto Central de Ciências (ICC) - ala norte ao Pavilhão João Calmon (PJC), que são locais de grande concentração de salas de aulas de diversos cursos da universidade. O mesmo se pode dizer da travessia que liga a Faculdade de Tecnologia (FT) ao ICC Norte, citada por $17 \%$ dos respondentes. Em ordem de citações aparecem, na sequência, a faixa que dá acesso ao Restaurante Universitário (RU), lembrada por 13,3\% dos pedestres pesquisados e os $8,1 \%$ que se referiram à principal faixa de entrada do campus, localizada na Avenida L3, em frente à Faculdade de Tecnologia (FT). 


\subsection{FATORES QUE INFLUENCIAM O COMPORTAMENTO DURANTE A TRAVESSIA NA FAIXA}

Os resultados obtidos pelas respostas das partes II, III, IV e $\mathrm{V}$ do questionário, respectivamente correspondentes à investigação do comportamento em relação à faixa, histórico em relação à utilização da faixa, ambiente de travessia e hábitos de transporte, são apresentados nos subitens a seguir. Como o questionário de pesquisa utilizado na terceira etapa do método é composto por seis partes, optou-se, primeiramente, por analisar cada instrumento em separado, para estabelecer os construtos latentes por eles determinados, seus indicadores e carga fatorial.

A amostra total da pesquisa conta com 408 questionários respondidos, que forneceram a base de dados para os tratamentos realizados com o pacote estatístico SPSS - Statistical Package for the Social Sciences. O tratamento estatístico dos dados, coletados pelos quatro instrumentos de pesquisa acima relatados, foi realizado de forma idêntica, seguindo uma sequência de testes descrita no item 4.5.1, cujos resultados são apresentados a seguir.

\subsubsection{Comportamento em relação a faixa}

O estudo do comportamento do pedestre em relação à faixa, a partir dos construtos baseados nos utilizados por Bamberg et al (2003), pretende identificar que fatores afetam o comportamento do pedestre em atravessar na faixa. Para realizar tal estudo, foram coletadas informações sobre atitude, norma subjetiva, controle percebido, intenção, através do instrumento que compõe a Parte II da terceira etapa do método, englobando as questões de número 12 a 19 (ver apêndice III). A seguir são apresentados os resultados da sequência de testes de análise deste instrumento.

\section{a) Fatorabilidade da matriz}

A

Tabela 5.2 apresenta os resultados do índice de Kaiser-Meyer-Olkin (KMO) e do Teste de Esfericidade de Bartlett. O Teste de Esfericidade de Bartlett apresentou uma significância $p<0,05$, indicando que a matriz de dados desse instrumento é fatorável, rejeitando a hipótese nula de que a matriz de dados é similar a uma matriz-identidade. $\mathrm{O}$ valor de KMO mostra que a matriz de dados do instrumento é razoável para a aplicação da análise fatorial exploratória. 
Tabela 5.2 - KMO e Teste de Esfericidade de Bartlett - Comportamento em relação a faixa.

\begin{tabular}{l|l|r}
\hline Medida Kaiser-Meyer-Olkin de adequação de amostragem. & 0,63 \\
\hline Teste de esfericidade de Bartlett & Aprox. Qui-quadrado & 769,91 \\
\cline { 2 - 3 } & gl & 28 \\
\cline { 2 - 3 } & Sig. & 0,00 \\
\hline
\end{tabular}

\section{b) Análise fatorial exploratória - AFE}

A Figura 5.14 apresenta o gráfico scree plot dos autovalores dos indicadores do comportamento em relação a faixa. Pode-se perceber que o gráfico não apresenta, como o teste prevê, na parte próxima ao eixo horizontal, uma linha aproximadamente reta. Tampouco pode ser visualizado claramente o “cotovelo” que separa os pontos acima da linha reta - associados com fatores não triviais.

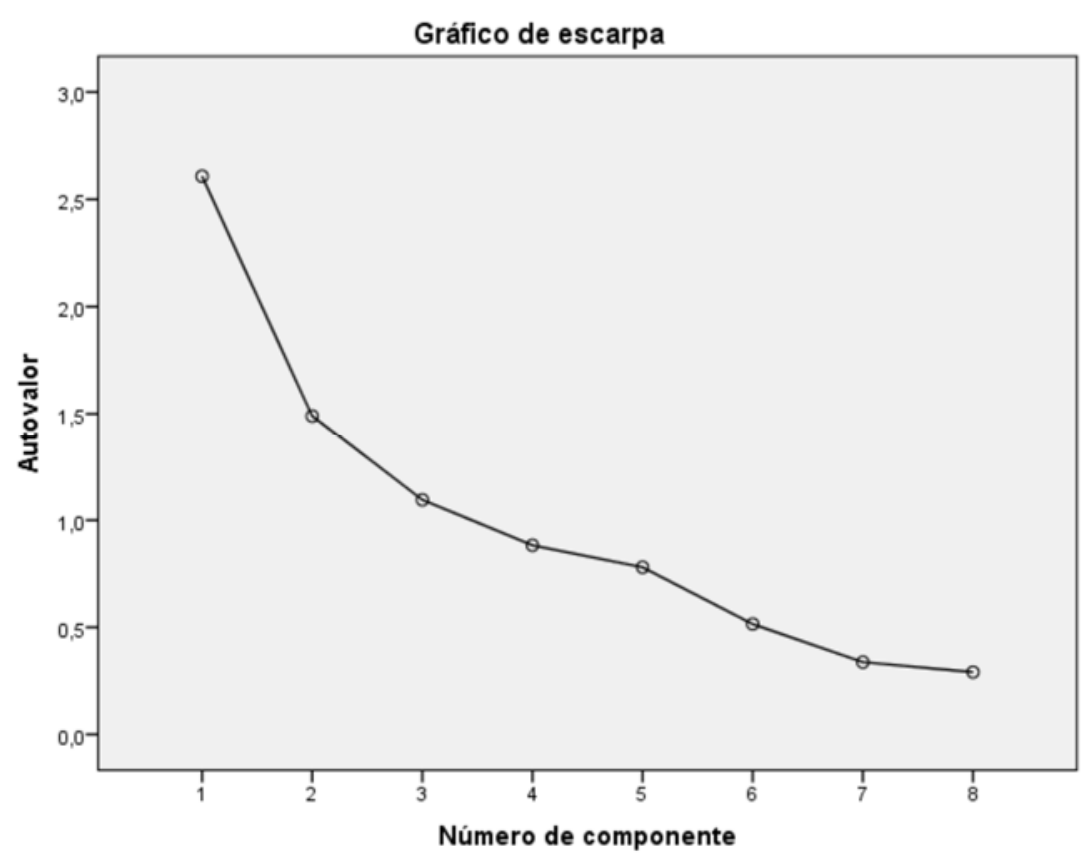

Figura 5.14 - Scree plot dos autovalores dos indicadores do comportamento em relação a faixa.

A Teoria do Comportamento Planejado (TCP) preconiza quatro construtos latentes: atitude, norma social, percepção de controle comportamental e intenção. Então, com embasamento na teoria, foi estabelecida a investigação de quatro fatores, relativos a cada um dos construtos da teoria. A Tabela 5.3 apresenta a matriz de componentes, obtida por rotação Varimax, com as cargas fatoriais de cada indicador nos fatores estabelecidos. 
Tabela 5.3 - Matriz de componente rotativa ${ }^{a}$ dos indicadores do comportamento em relação à faixa.

\begin{tabular}{l|c|c|c|c}
\hline \multirow{2}{*}{\multicolumn{1}{c|}{ INDICADOR }} & \multicolumn{4}{|c}{ COMPONENTE } \\
\cline { 2 - 5 } & $\begin{array}{c}\text { NORMA } \\
\text { SOCIAL }\end{array}$ & INTENÇÃO & $\begin{array}{c}\text { PERCEPC̃̃O } \\
\text { CONTROLE }\end{array}$ & ATITUDE \\
\hline norma social 2 & 0,90 & & & \\
\hline norma social 1 & 0,88 & & & \\
\hline atitude 1 & 0,48 & & 0,35 & \\
\hline intenção 2 & & 0,90 & & \\
\hline intenção 1 & & 0,89 & & \\
\hline controle comp 1 & & & 0,82 & \\
\hline controle comp 2 & & & 0,80 & \\
\hline atitude 2 & & & & 0,97 \\
\hline
\end{tabular}

Método de Extração: Análise de Componente Principal.

Método de Rotação: Varimax com Normalização de Kaiser.

a. Rotação convergida em 5 iterações.

Ao analisar os valores das cargas fatoriais, pode-se perceber que todos ficam acima de 0,4, indicando uma relação forte para explicar os construtos latentes. Pode-se perceber também que o indicador "atitude 1", resultado da pergunta 12 do questionário, apresenta carga fatorial em dois fatores diferentes do fator "atitude", isso pode indicar que a questão do questionário não foi bem elaborada. Para obedecer aos fatores da TCP, o indicador "atitude 1 " foi relacionado ao fator atitude na análise fatorial confirmatória da MME.

\section{c) Modelagem por equação estrutural-MEE}

Primeiramente foi feita a análise exploratória e descritiva dos dados, a partir das medidas de tendência central - média, das medidas de distribuição - assimetria e achatamento, com o intuito de verificar a exatidão da entrada de dados, os casos omissos ocorrentes e a presença de casos extremos. A partir da identificação e especificação do modelo, os parâmetros foram estimados pelo método de máxima verossimilhança, com o auxílio do programa AMOS do SPSS.

A Figura 5.15 e a Tabela 5.4 apresentam, respectivamente, o modelo da análise fatorial confirmatória e índice de ajustes do modelo e a matriz de covariância residual das oito variáveis. O modelo de quatro fatores correlacionados foi o que apresentou os melhores índices de ajuste. Os índices de ajuste do modelo de quatro fatores correlacionados estão de acordo com os parâmetros apresentados na Tabela 4.5, com exceção do índice RMSEA (Root Mean Square Error of Aproximation). De acordo com a referida tabela, esse índice é 
reconhecido como um dos critérios mais informativos sobre MEE, pois considera o erro de aproximação na população, que expressa a medida de discrepância em graus de liberdade.

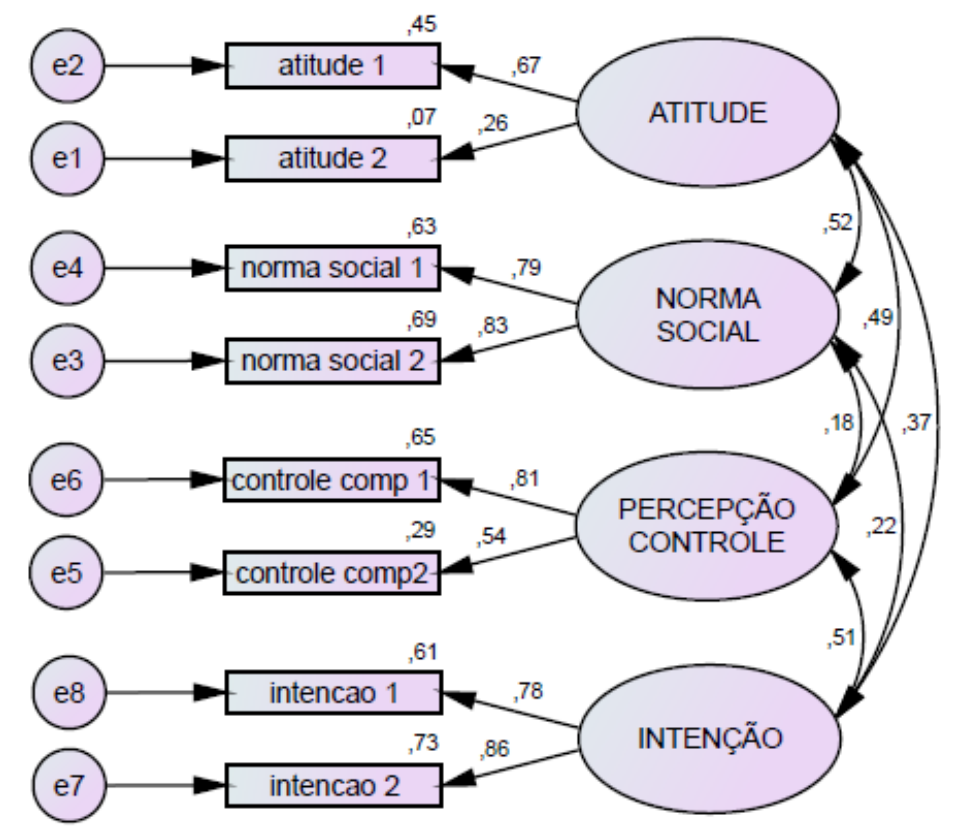

\begin{tabular}{lcccccccccc}
\hline MODELO & $\chi^{2}$ & df & $\chi^{2} /$ df & NFI & CFI & RMSEA & GFI & TLI & RMR & SRMR \\
\hline $\begin{array}{l}\text { Quatro fatores } \\
\text { Correlacionados }\end{array}$ & 45,35 & 14 & 3,24 & 0,94 & 0,96 & 0,70 & 0,97 & 0,92 & 0,12 & 0,03 \\
\hline
\end{tabular}

Figura 5.15 - Modelo da análise fatorial confirmatória e índice de ajustes do modelo

Tabela 5.4 - Matriz de covariância residual das oito variáveis.

\begin{tabular}{l|cccccccc}
\hline \multicolumn{1}{l|}{} & $\mathrm{p} 18$ & $\mathrm{p} 19$ & $\mathrm{p} 16$ & $\mathrm{p} 17$ & $\mathrm{p} 14$ & $\mathrm{p} 15$ & $\mathrm{p} 12$ & $\mathrm{p} 13$ \\
\hline intenção 1 & 0,00 & & & & & & & \\
intenção 2 & 0,00 & 0,00 & & & & & & \\
controle comp 1 & $-0,12$ &, 24 & 0,00 & & & & & \\
controle comp 2 & 1,13 & $-1,23$ & 0,00 & 0,00 & & & & \\
norma social 1 & 0,64 & 0,45 & $-0,80$ & 1,21 & 0,00 & & & \\
norma social 2 & $-1,14$ & 0,04 & 0,11 & 0,64 & 0,00 & 0,00 & & \\
atitude 1 & $-0,52$ & 0,21 & $-0,06$ & $-0,16$ & $-0,19$ & 0,32 & 0,00 & \\
atitude 2 & 0,62 & 0,13 & $-0,58$ & 3,33 & $-0,10$ & $-0,66$ & 0,00 & 0,00 \\
\hline
\end{tabular}

A matriz de resíduos padronizados indica valores baixos, com exceção da covariância entre os indicadores "atitude 2" e "controle comp 2", cuja covariância exibe o valor 3,33. Byrne (2010) considera altos os valores maiores que 2,58.

\section{d) Confiabilidade do instrumento}

Como foi colocado no item 4.5.1, a confiabilidade é o grau em que um conjunto de indicadores de uma variável latente (construto) é consistente em suas mensurações e, quanto mais próximo de 1, maior confiabilidade entre os indicadores. Pode-se observar, pelos 
valores de $\alpha$ apresentados na Tabela 5.5, que os construtos "intenção" e "norma social" possuem os indicadores mais confiáveis, maiores até mesmo que o índice para o instrumento completo.

Tabela 5.5 - Valores do Teste de Alfa de Cronbach para os construtos do comportamento em relação a faixa.

\begin{tabular}{|c|c|c|c|c|c|c|}
\hline CONSTRUTO & INDICADORES & Válidos & $\begin{array}{c}\mathbf{N} \\
\text { Excluídos }^{a} \\
\end{array}$ & Total & $\begin{array}{c}\alpha \\
\text { CRONBACH } \\
\end{array}$ & $\begin{array}{c}\mathrm{N}^{\circ} \\
\text { Itens } \\
\end{array}$ \\
\hline Atitude & p12 e p13 & 408 & 0 & 408 & 0,30 & 2 \\
\hline Norma social & p14 e p15 & 408 & 0 & 408 & 0,79 & 2 \\
\hline Percepção controle & p16 e p17 & 408 & 0 & 408 & 0,61 & 2 \\
\hline Intenção & p18 e p19 & 408 & 0 & 408 & 0,80 & 2 \\
\hline $\begin{array}{l}\text { Instrumento } \\
\text { completo }\end{array}$ & p12 a p19 & 408 & 0 & 408 & 0,70 & 8 \\
\hline
\end{tabular}

a. Exclusão por método listwise com base em todas as variáveis do procedimento.

\subsubsection{Histórico de utilização da faixa}

O instrumento faz um apanhado do histórico do comportamento do pedestre no que se refere à utilização das faixas de travessia. É interessante notar os resultados apontando que 40,7\% dos entrevistados foram ensinados desde criança a atravessarem na faixa de pedestres, o fato de que morar em localidades onde se respeita a faixa faz com que 50,7\% dos entrevistados passem a usar a faixa e, por fim, $46,5 \%$ dos entrevistados passaram a usar a faixa de pedestres após campanhas educativas de uso da faixa. Os testes específicos para esse instrumento são apresentados a seguir.

\section{a) Fatorabilidade da matriz}

Os resultados do índice de Kaiser-Meyer-Olkin (KMO) e do teste de esfericidade de Barlett (Tabela 5.6) mostram que a matriz do estudo é passível de fatoração, mesmo apresentado um KMO razoável.

Tabela 5.6 - KMO e Teste de Esfericidade de Bartlett - Histórico de utilização faixa.

\begin{tabular}{l|l|r}
\hline Medida Kaiser-Meyer-Olkin de adequação de amostragem. & 0,65 \\
\hline \multirow{2}{*}{ Teste de esfericidade de Bartlett } & Aprox. Qui-quadrado & 576,12 \\
\cline { 2 - 3 } & gl & 21 \\
\cline { 2 - 3 } & Sig. & 0,00 \\
\hline
\end{tabular}




\section{b) Análise fatorial exploratória - AFE}

Como acontecido com o instrumento anterior, que analisa os fatores que remetem ao comportamento em relação à faixa, o gráfico scree plot (Figura 5.16) do presente instrumento também não evidencia nem a linha de fundo nem um “cotovelo” proeminente. Assim, como este instrumento não tem uma teoria delineada sobre os fatores que compõem os construtos latentes, o número de fatores foi definido pelo critério de autovalor (eigenvalue), considerando os valores maiores que 1,0.

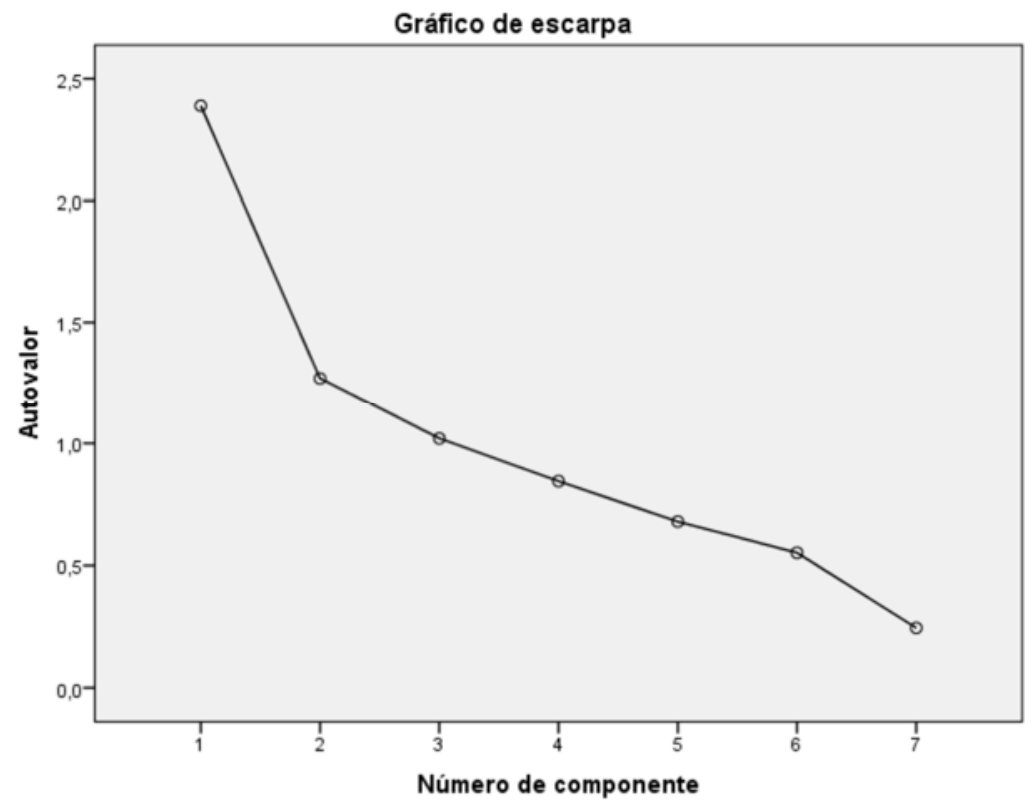

Figura 5.16 - Scree plot dos autovalores dos indicadores do histórico de utilização da faixa

A partir do critério dos autovalores, foram estabelecidos dois fatores de análise para os construtos latentes. A Tabela 5.7 apresenta a matriz obtida por rotação Varimax para os fatores que determinam os construtos latentes a serem modelados, com seus respectivos indicadores e cargas fatoriais.

Tabela 5.7 - Matriz de componente rotativa ${ }^{a}$ dos indicadores do histórico de travessia na faixa.

\begin{tabular}{l|c|c}
\hline \multirow{2}{*}{\multicolumn{1}{c|}{ INDICADOR }} & \multicolumn{2}{c}{ COMPONENTE } \\
\cline { 2 - 3 } & $\begin{array}{c}\text { LOCAL DE } \\
\text { TRAVESSIA }\end{array}$ & $\begin{array}{c}\text { MUDANÇA DE } \\
\text { COMPORTAMENTO }\end{array}$ \\
\hline perto trabalho escola & 0,891 & \\
\hline perto casa & 0,882 & \\
\hline morar lugar respeita & 0,558 & 0,850 \\
\hline após acidente & & 0,542 \\
\hline após campanha & 0,420 & 0,512 \\
\hline opinião pessoas & 0,341 & 0,408 \\
\hline desde criança & & \\
\hline
\end{tabular}

Método de Extração: Análise de Componente Principal.

Método de Rotação: Varimax com Normalização de Kaiser.

a. Rotação convergida em 5 iterações. 
Ao observar os valores das cargas fatoriais de cada indicador dentro dos fatores, pode-se constatar que as opções do questionário relativas à questão "Eu atravesso a rua na faixa de pedestres...”, representadas pelos indicadores “após campanha” e “opinião pessoas” apresentaram cargas fatoriais em mais de um fator.

\section{c) Modelagem por equação estrutural - MEE}

Conforme o apresentado no item 4.5.1, o modelo de mensuração é um modelo de grupos independentes, ou seja, um modelo de fator no qual nenhum indicador é carregado em mais de um fator comum. Os indicadores que possuem carga fatorial em dois fatores distintos foram analisados dentro do fator de maior carregamento fatorial.

A Figura 5.17, apresenta a análise fatorial combinatória e os índices de ajuste para o modelo. Os melhores índices foram obtidos com o modelo de dois fatores correlacionados. Os índices RMSEA, TLI e SRMR não apresentaram resultados satisfatórios.

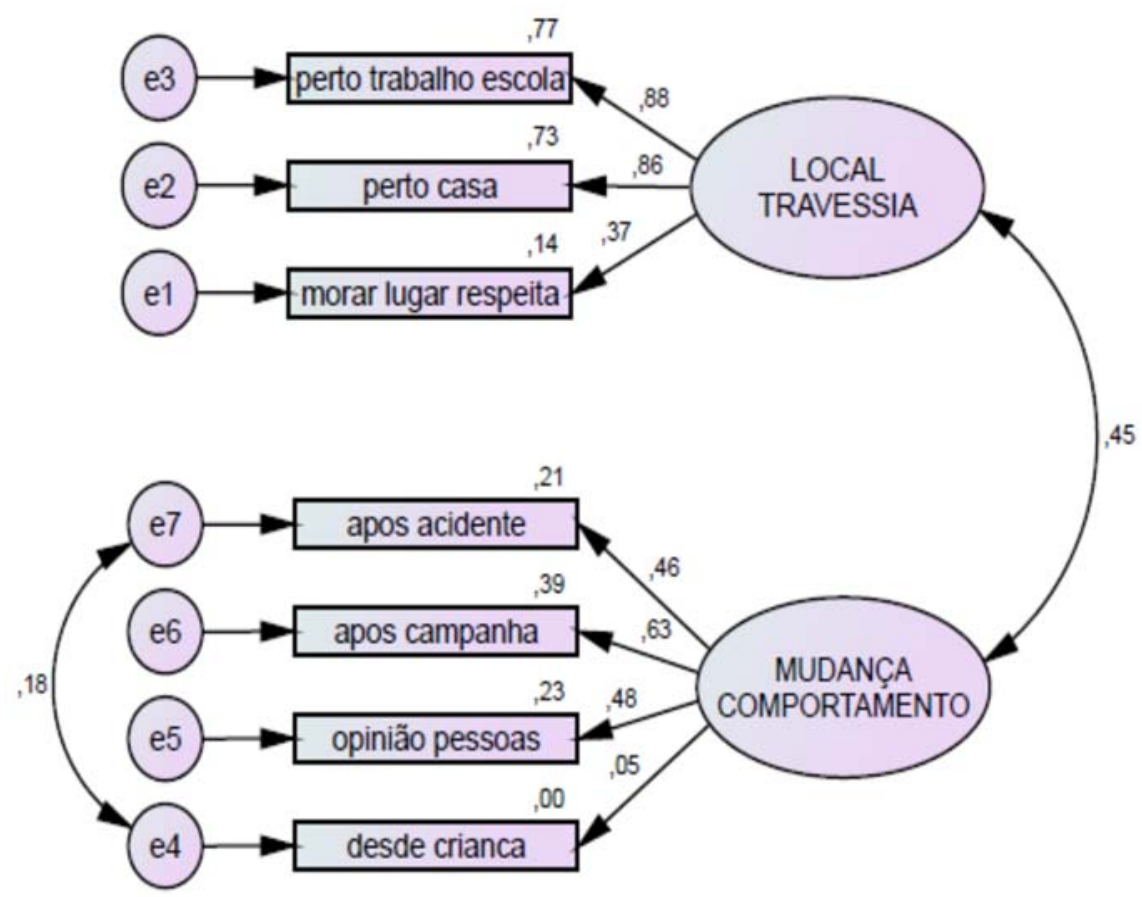

\begin{tabular}{lcccccccccc}
\hline MODELO & $\chi^{2}$ & df & $\chi^{2} /$ df & NFI & CFI & RMSEA & GFI & TLI & RMR & SRMR \\
\hline $\begin{array}{l}\text { Dois fatores } \\
\text { Correlacionados }\end{array}$ & 54,60 & 12 & 4,55 & 0,91 & 0,92 & 0,09 & 0,97 & 0,87 & 0,10 & 0,06 \\
\hline
\end{tabular}

Figura 5.17 - Modelo da análise fatorial confirmatória e índice de ajustes do modelo 
O primeiro índice analisado (RMSEA), que considera o erro de aproximação na população, excede o valor máximo $(0,08)$ para ser considerado razoável. O TLI que inclui um ajuste para a complexidade do modelo, não atingiu o valor mínimo (maior que 0,90) para representar um bom ajuste. O SRMR, que representa a média dos resíduos padronizados, e considera um bom ajuste para valores mais próximos de zero, também excede o valor máximo de 0,05. A Tabela 5.8 mostra a matriz de covariância residual das variáveis que compõem o instrumento. Com exceção da covariância entre os indicadores “morar lugar respeita” e “desde criança”, que apresenta um valor absoluto mais alto do que o máximo $(2,58)$ considerado por Byrne $(2010)$, os valores restantes são considerados satisfatórios.

Tabela 5.8 - Matriz de covariância residual das sete variáveis.

\begin{tabular}{l|ccccccc}
\hline \multicolumn{1}{l}{} & $\mathrm{p} 20.2$ & $\mathrm{p} 20.3$ & $\mathrm{p} 20.7$ & $\mathrm{p} 20.1$ & $\mathrm{p} 20.5$ & $\mathrm{p} 20.6$ & $\mathrm{p} 20.4$ \\
\hline após acidente & 0,00 & & & & & & \\
após campanha & 0,68 & 0,00 & & & & & \\
opinião pessoas & 1,03 & $-1,26$ & 0,00 & & & & \\
desde criança & 0,00 & $-0,65$ & 0,47 & 0,00 & & & \\
perto trabalho escola & $-2,76$ & 0,23 & 1,43 & 0,70 & 0,00 & & \\
perto casa & $-2,45$ & 0,62 & 1,17 & 0,81 & 0,04 & 0,00 & \\
morar lugar respeita & 0,65 & 4,47 & 1,54 & $-0,28$ & $-0,06$ & $-0,34$ & 0,00 \\
\hline
\end{tabular}

\section{d) Confiabilidade do instrumento}

Os valores para o Alfa de Cronbach para cada construto latente do instrumento são apresentados na Tabela 5.9. O fator “mudança de comportamento” foi o que obteve o menor valor de $\alpha$, fato provavelmente decorrente da inserção do indicador “desde criança” para completar a questão “Eu atravesso a rua na faixa de pedestres...”. Pois mesmo uma interpretação literal da frase, que propõe o indicador como complemento da sentença, denota que não houve mudança de comportamento por parte do respondente. As confiabilidades, do fator "local de travessia” assim como do instrumento completo, foram consideradas razoáveis.

Tabela 5.9 - Valores do Teste de Alfa de Cronbach para os construtos do histórico de utilização da faixa.

\begin{tabular}{|c|c|c|c|c|c|c|}
\hline CONSTRUTO & INDICADORES & Válidos & $\begin{array}{c}\mathbf{N} \\
\text { Excluídos }{ }^{a}\end{array}$ & Total & $\begin{array}{c}\alpha \\
\text { CRONBACH } \\
\end{array}$ & $\begin{array}{l}\mathrm{N}^{0} \\
\text { Itens }\end{array}$ \\
\hline $\begin{array}{l}\text { Local de } \\
\text { travessia }\end{array}$ & p20.4, p20.5 e p20.6 & 408 & 0 & 408 & 0,72 & 3 \\
\hline $\begin{array}{l}\text { Mudança de } \\
\text { comportamento }\end{array}$ & $\begin{array}{l}\text { p20.1, p20.2, p20.3 } \\
\text { e p 20.7 }\end{array}$ & 408 & 0 & 408 & 0,46 & 4 \\
\hline Instrumento & p20.1a p 20.7 & 408 & 0 & 408 & 0,64 & 7 \\
\hline
\end{tabular}

a. Exclusão por método listwise com base em todas as variáveis do procedimento. 


\subsubsection{Ambiente de travessia}

As questões que compõem esse instrumento de pesquisa tentam identificar fatores que estimulem o pedestre a fazer uso da faixa. Fica evidente que placas de sinalização visíveis, e faixas de pedestres pintadas em bom estado de conservação são fundamentais para estimular o indivíduo a fazer uso da faixa. Colocar faixas estrategicamente posicionadas em locais visíveis também é uma boa solução. Por fim, uma política pública que desestimule os motoristas de estacionarem seus carros próximos a faixa de pedestre também parece ser uma medida adequada.

\section{a) Fatorabilidade da matriz}

Os resultados do índice KMO e do Teste de Esfericidade de Bartlett, apresentados na Tabela 5.10, mostram que a matriz de resultados obtida pelos indicadores do instrumento é fatorável.

\begin{tabular}{|c|c|c|}
\hline \multicolumn{2}{|c|}{ Medida Kaiser-Meyer-Olkin de adequação de amostragem. } & 0,74 \\
\hline \multirow[t]{3}{*}{ Teste de esfericidade de Bartlett } & Aprox. Qui-quadrado & 1900,02 \\
\hline & gl & 78 \\
\hline & Sig. & 0,00 \\
\hline
\end{tabular}

\section{b) Análise fatorial exploratória - AFE}

O scree plot apresentado pela Figura 5.18 mostra uma adequação maior do gráfico ao que preconiza o teste. Podem ser observados uma tendência de formação de uma linha de fundo e um "cotovelo" indicando três fatores como não triviais. Esses três fatores também são confirmados pelo teste dos autovalores maiores que 1,0.

A matriz de componentes, exibida na Tabela 5.11 e obtida por rotação Varimax, apresenta as cargas fatoriais dos indicadores que compõem cada fator. Pode-se perceber que nenhum indicador sofreu carregamento fatorial em dois fatores distintos e que as cargas fatoriais exercem uma relação forte $(>0,4)$ para explicar os fatores latentes. 


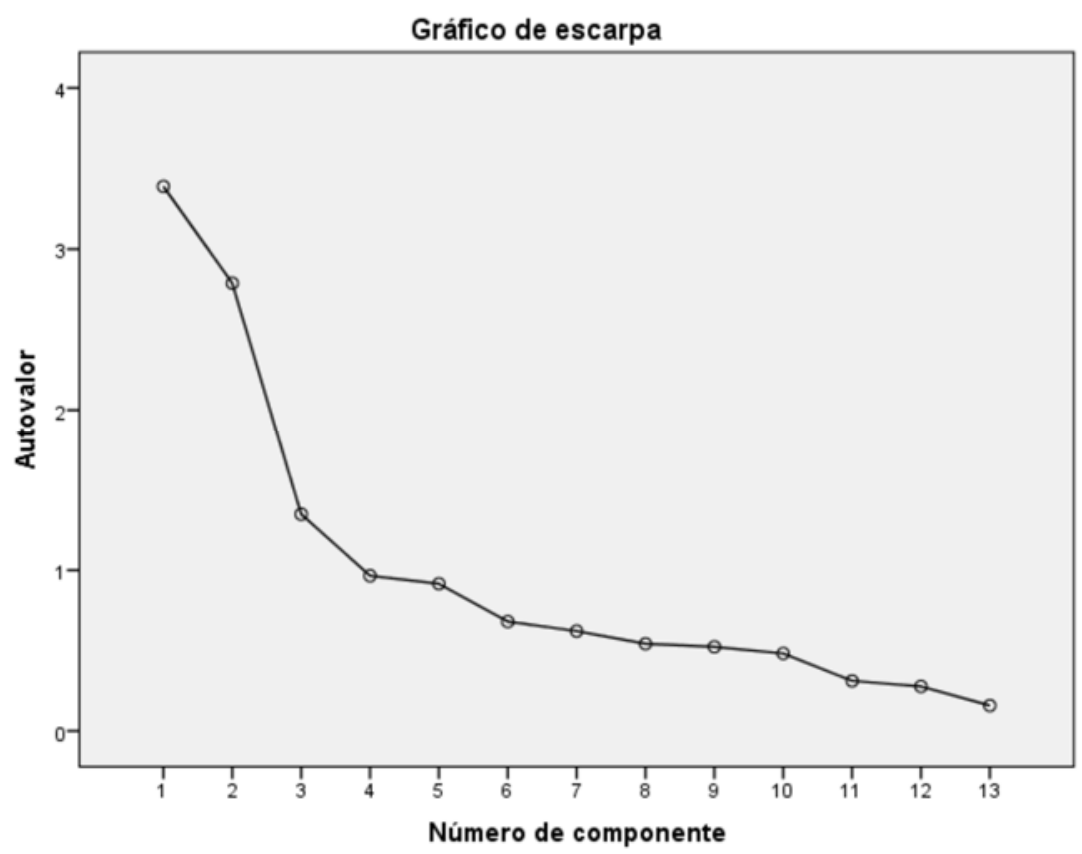

Figura 5.18 - Scree plot dos autovalores dos indicadores do comportamento em relação a faixa

Tabela 5.11 - Matriz de componente rotativa ${ }^{a}$ dos indicadores do ambiente de travessia.

\begin{tabular}{l|c|c|c}
\hline \multirow{2}{*}{\multicolumn{1}{c|}{ INDICADOR }} & \multicolumn{3}{c}{ COMPONENTE } \\
\cline { 2 - 4 } & $\begin{array}{c}\text { CONDIÇÕES } \\
\text { ADVERSAS }\end{array}$ & INSTALAÇÕES & $\begin{array}{c}\text { CONDIÇÕES } \\
\text { FAVORÂVEIS }\end{array}$ \\
\hline ônibus e caminhões & 0,817 & & \\
\hline carros e motos & 0,812 & & \\
\hline local congestionado & 0,653 & & \\
\hline bicicleta & 0,651 & & \\
\hline noite & 0,595 & & \\
\hline carros estacionados & 0,491 & & \\
\hline pintura da faixa & & 0,809 & \\
\hline placa sinalização & & 0,807 & \\
\hline motorista me vê & & 0,801 & 0,797 \\
\hline vejo veículos & & 0,762 & 0,726 \\
\hline controle de velocidade & & & \\
\hline poucos veículos & & & \\
\hline dia & & & \\
\hline
\end{tabular}

Método de Extração: Análise de Componente Principal.

Método de Rotação: Varimax com Normalização de Kaiser.

a. Rotação convergida em 5 iterações.

\section{c) Modelagem por equação estrutural - MEE}

A Figura 5.19 mostra os fatores correlacionados na análise fatorial confirmatória, assim como os índices de ajuste do modelo. De acordo com o apresentado na Tabela 4.5, somente o índice SRMR apresenta um valor maior do que o considerado adequado, que é 0,05. 


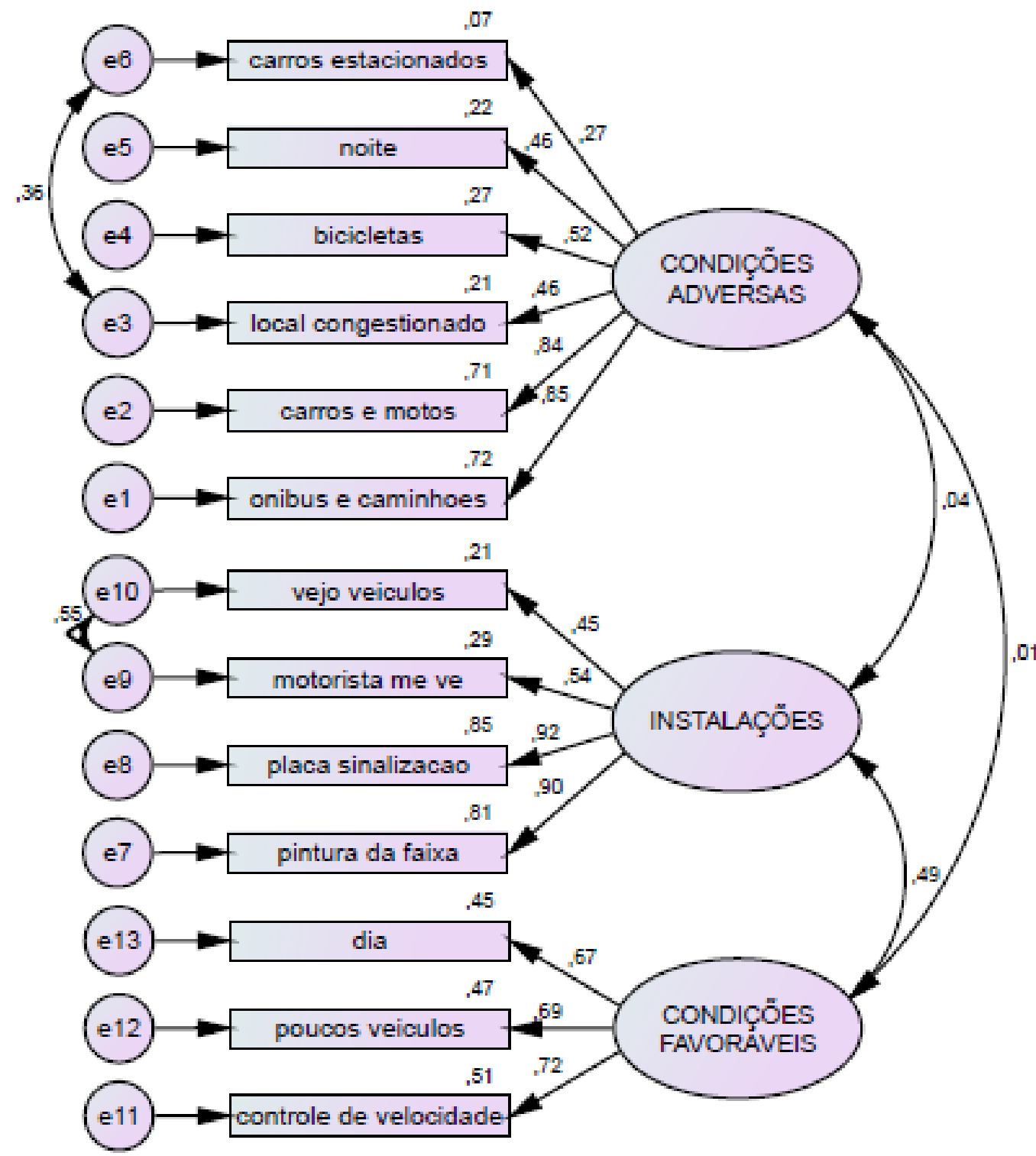

\begin{tabular}{lcccccccccc}
\hline MODELO & $\chi^{2}$ & df & $\chi^{2} /$ df & NFI & CFI & RMSEA & GFI & TLI & RMR & SRMR \\
\hline $\begin{array}{l}\text { Três fatores } \\
\text { Correlacionados }\end{array}$ & 107,55 & 60 & 1,79 & 0,94 & 0,97 & 0,04 & 0,96 & 0,97 & 0,06 & 0,06 \\
\hline
\end{tabular}

Figura 5.19 - Modelo da análise fatorial confirmatória e índice de ajustes do modelo.

Os valores de covariância residual das treze variáveis do instrumento, conforme mostra a

Tabela 5.12, se aproximam do considerado ideal considerado por Byrne (2012). O maior valor de covariância ocorreu entre os indicadores "carros estacionados" e "motorista me vê". 
Tabela 5.12 - Matriz de covariância residual das treze variáveis.

\begin{tabular}{|c|c|c|c|c|c|c|c|c|c|c|c|c|c|}
\hline & $\stackrel{\pi}{\partial}$ &  & 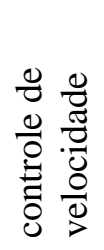 & $\begin{array}{l}\frac{0}{0} \\
\frac{0}{0} \\
0 \\
0 \\
0 \\
0 \\
0 \\
0\end{array}$ & 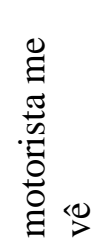 & 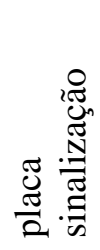 & 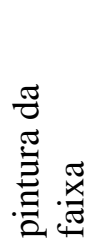 & 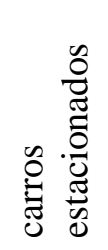 & $\stackrel{\mathscr{C}}{\stackrel{\varrho}{\varrho}}$ & $\frac{\frac{\pi}{0}}{\frac{0}{0}}$ & 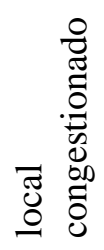 & $\begin{array}{l}\tilde{0} \\
\stackrel{0}{0} \\
\vdots \\
0 \\
0 \\
0 \\
\vdots \\
0\end{array}$ & 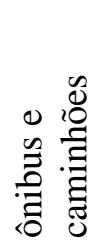 \\
\hline 21.12 & 0,00 & & & & & & & & & & & & \\
\hline 1.10 & $-0,05$ & 0,00 & & & & & & & & & & & \\
\hline p21.11 & $-0,15$ & 0,19 & 0,00 & & & & & & & & & & \\
\hline p21.4 & 2,67 & 0,59 & 0,67 & 0,00 & & & & & & & & & \\
\hline p21.3 & 1,44 & 1,93 & 1,11 & 0,00 & 0,00 & & & & & & & & \\
\hline p21.2 & 0,42 & $-0,67$ & 0,01 & $-0,23$ & 0,00 & 0,00 & & & & & & & \\
\hline p21.1 & 0,38 & $-0,32$ & $-0,40$ & 0,15 & $-0,18$ & 0,02 & 0,00 & & & & & & \\
\hline p21.5 & $-2,18$ & $-3,27$ & $-2,37$ & $-3,24$ & $-2,85$ & $-2,87$ & $-2,48$ & ,00 & & & & & \\
\hline p21.13 & 0,93 & $-0,23$ & 1,82 & $-0,83$ & $-1,37$ & 1,41 & 0,93 & 1,26 & 0,00 & & & & \\
\hline p21.9 & 2,63 & 1,78 & 2,68 & 0,67 & 0,23 & $-0,09$ & $-0,21$ & 1,53 & 0,62 & 0,00 & & & \\
\hline p21.6 & $-0,60$ & $-2,83$ & $-1,34$ & $-0,80$ & $-0,98$ & $-2,06$ & $-0,83$ & 0,00 & 0,47 & 1,23 & 0,00 & & \\
\hline p21.7 & 1,46 & $-0,93$ & 0,14 & 0,12 & 0,46 & 0,48 & 0,47 & $-0,41$ & $-0,25$ & $-0,02$ & $-0,28$ & 0,00 & \\
\hline p21.8 & 0,64 & $-1,90$ & $0-, 36$ & $-1,00$ & $-0,56$ & $-0,45$ & 0,04 & $-0,17$ & $-0,03$ & $-0,34$ & $-0,08$ & 0,10 & 0,00 \\
\hline
\end{tabular}

\section{d) Confiabilidade do instrumento}

Os valores de Alfa de Cronbach apresentados na Tabela 5.13 mostram que os três fatores compostos pelos indicadores do instrumento são, isoladamente, mais confiáveis que o instrumento completo. Isso pode ser decorrente do fato que o instrumento apresenta indicadores positivos e negativos em relação aos fatores que constituem o ambiente de travessia.

Tabela 5.13 - Valores do Teste de Alfa de Cronbach para os construtos do ambiente de travessia.

\begin{tabular}{|c|c|c|c|c|c|c|}
\hline CONSTRUTO & INDICADORES & Válidos & $\begin{array}{c}\mathbf{N} \\
\text { Excluídos a }^{a}\end{array}$ & Total & $\begin{array}{c}\alpha \\
\text { CRONBACH }\end{array}$ & $\begin{array}{c}\mathrm{N}^{\mathbf{o}} \\
\text { Itens }\end{array}$ \\
\hline $\begin{array}{l}\text { Condições } \\
\text { adversas }\end{array}$ & $\begin{array}{l}\text { p21.5, p21.6, } \\
\text { p21.7, p21.8, } \\
\text { p21.9 e p21.13 }\end{array}$ & 408 & 0 & 408 & 0,76 & 6 \\
\hline Instalações & $\begin{array}{l}\text { p21.1, p21.2, } \\
\text { p21.3 e p21.4 }\end{array}$ & 408 & 0 & 408 & 0,83 & 4 \\
\hline $\begin{array}{l}\text { Condições } \\
\text { favoráveis }\end{array}$ & $\begin{array}{l}\text { p21.10, p21.11 } \\
\text { e p21.12 }\end{array}$ & 408 & 0 & 408 & 0,73 & 3 \\
\hline $\begin{array}{l}\text { Instrumento } \\
\text { completo }\end{array}$ & p21.1 a p21.13 & 408 & 0 & 408 & 0,66 & 13 \\
\hline
\end{tabular}

\footnotetext{
a. Exclusão por método listwise com base em todas as variáveis do procedimento.
} 


\subsubsection{Hábitos de transporte}

Ao analisar os dados coletados por esse instrumento de forma descritiva, fica muito clara a preferência dos respondentes pelo modo de transporte individual e motorizado para os seus deslocamentos de rotina. A Figura 5.20 mostra que $63 \%$ dos respondentes utilizam carro $(61 \%)$ ou moto $(2 \%)$.

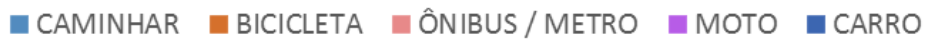

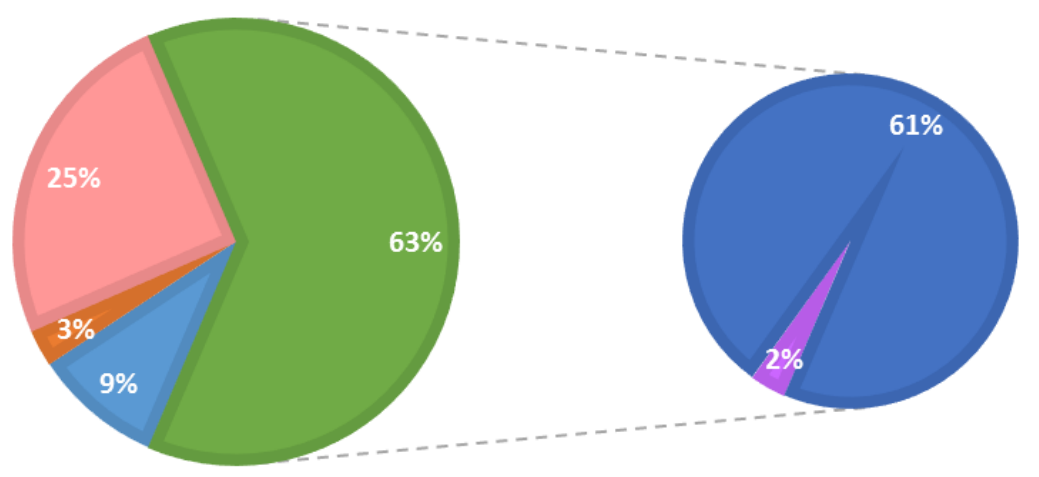

Figura 5.20 - Proporção do meio de transporte rotineiro utilizado pelos respondentes.

Também foi observado, conforme apresenta a Figura 5.21, que os deslocamentos a pé para chegar ao local de estudo ou trabalho representam os mais baixos índices de frequência de caminhada. Mais de $40 \%$ dos respondentes declararam nunca ir para o local de estudo caminhando e quase $60 \%$ dos respondentes nunca vão trabalhar a pé. Os motivos mais frequentes de deslocamento andando é, segundo os respondentes, a prática de exercícios físicos e acessar locais para se alimentar.

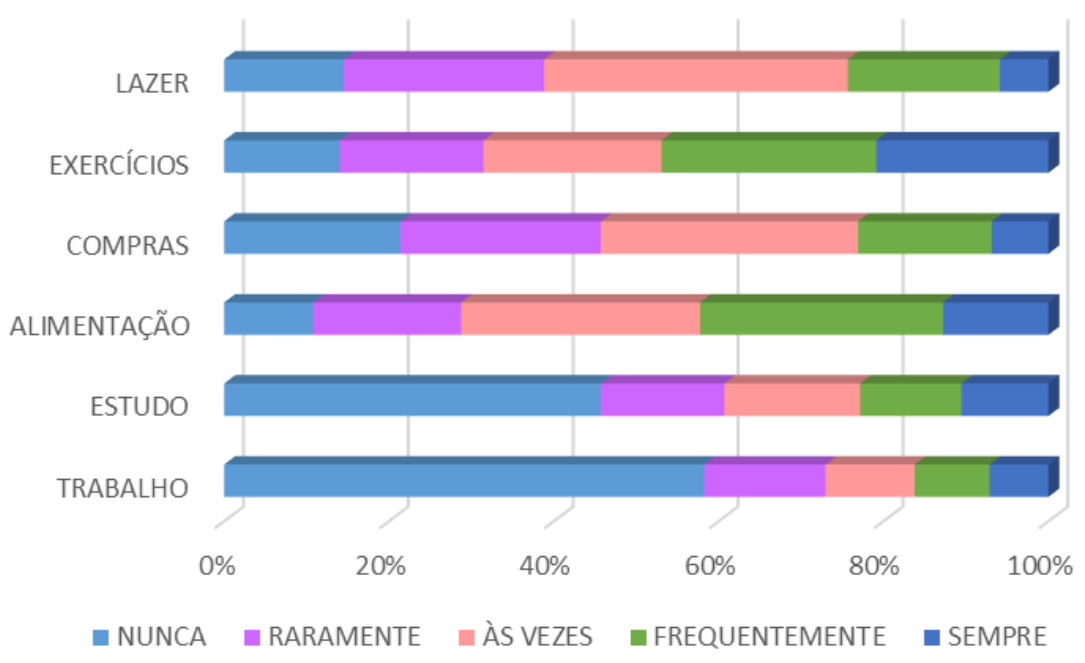

Figura 5.21 - Frequência em que utiliza a caminhada para desempenhar atividades. 


\section{a) Fatorabilidade da matriz}

A matriz que compõe o instrumento de análise dos hábitos de transportes apresentou o melhor índice de fatorabilidade para o teste KMO, conforme apresenta a Tabela 5.14. O resultado da significância do Teste de Esfericidade de Bartlett também foi satisfatório.

Tabela 5.14 - KMO e Teste de Esfericidade de Bartlett - hábitos de transporte.

\begin{tabular}{l|l|r}
\hline \multicolumn{2}{|c|}{ Medida Kaiser-Meyer-Olkin de adequação de amostragem. } & 0,79 \\
\hline Teste de esfericidade de Bartlett & Aprox. Qui-quadrado & 691,12 \\
\cline { 2 - 3 } & gl & 28 \\
\cline { 2 - 3 } & Sig. & 0,00 \\
\hline
\end{tabular}

\section{b) Análise fatorial exploratória - AFE}

O gráfico scree plot (Figura 5.22) apresenta claramente uma diferença de inclinação que marca o "cotovelo" de separação dos fatores triviais, demarcados pela reta de fundo, dos fatores não triviais, salientados após a mudança de inclinação da reta. Tanto por este teste quanto pelo teste dos autovalores, o instrumento indica dois fatores de construtos latentes.

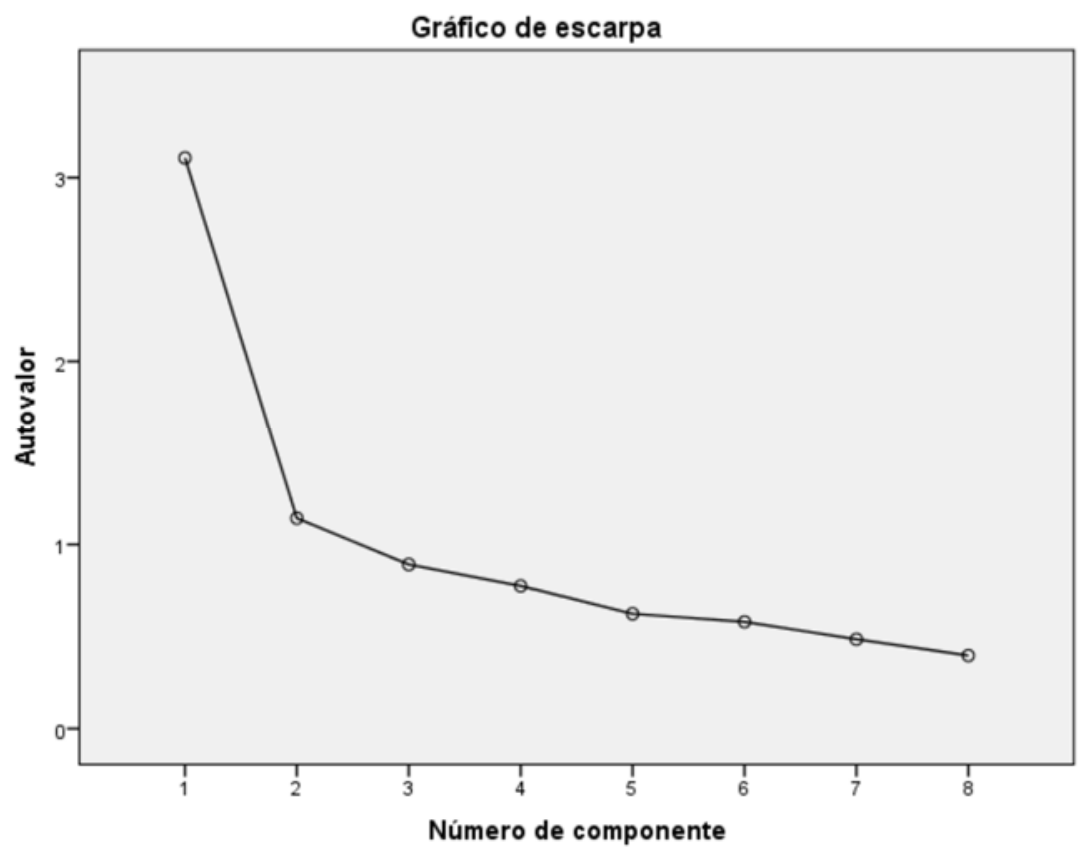

Figura 5.22 - Scree plot dos autovalores dos indicadores do comportamento em relação a faixa

Os fatores latentes do instrumento, seu indicadores e respectivas cargas fatoriais são apresentados na matriz de componentes rotativa da Tabela 5.15. O indicador “caminha 
compras" aparece presente nos dois fatores latentes, mas foi considerado como indicador apenas do fator com maior carga fatorial.

Tabela 5.15 - Matriz de componente rotativa ${ }^{\mathrm{a}}$ dos indicadores de hábitos de transporte.

\begin{tabular}{l|c|c}
\hline \multirow{2}{*}{ INDICADOR } & \multicolumn{2}{c}{ COMPONENTE } \\
\cline { 2 - 3 } & CAMINHA ROTINA & CAMINHA ESCOLHA \\
\hline caminha estudo & 0,745 & \\
\hline caminha trabalho & 0,688 & \\
\hline caminha alimentação & 0,643 & \\
\hline frequência caminha & 0,580 & 0,331 \\
\hline caminha compras & 0,553 & 0,798 \\
\hline caminha lazer & & 0,795 \\
\hline caminha esporte & & \\
\hline
\end{tabular}

Método de Extração: Análise de Componente Principal.

Método de Rotação: Varimax com Normalização de Kaiser.

a. Rotação convergida em 5 iterações.

\section{c) Modelagem por equação estrutural-MEE}

O modelo da análise fatorial confirmatória que apresentou os melhores ajustes foi o com dois fatores relacionados. A Figura 5.23 apresenta o modelo da AFC e os índices de ajustes. Esse instrumento foi o que obteve o modelo com melhor ajuste segundo os índices avaliados.



\begin{tabular}{lcccccccccc}
\hline MODELO & $\boldsymbol{\chi}^{\mathbf{2}}$ & df & $\boldsymbol{\chi}^{\mathbf{2}} / \mathbf{d f}$ & NFI & CFI & RMSEA & GFI & TLI & RMR & SRMR \\
\hline $\begin{array}{l}\text { Dois fatores } \\
\text { Correlacionados }\end{array}$ & 37,41 & 11 & 3,40 & 0,94 & 0,96 & 0,08 & 0,98 & 0,91 & 0,06 & 0,04 \\
\hline
\end{tabular}

Figura 5.23 - Modelo da análise fatorial confirmatória e índices de ajustes do modelo 
A matriz de covariância residual das variáveis, apresentada na Tabela 5.16, mostra que os valores de covariância se enquadram totalmente no critério proposto por Byrne (2010), considera altos os valores maiores que 2,58. O maior valor de covariância $(1,32)$ entre os indicadores do instrumento ocorreu entre os indicadores "caminha estudo" e "caminha lazer".

Tabela 5.16 - Matriz de covariância residual das sete variáveis.

\begin{tabular}{l|rrrrrrr}
\hline & $\mathrm{p} 24.5$ & $\mathrm{p} 24.6$ & $\mathrm{p} 24.4$ & $\mathrm{p} 24.3$ & $\mathrm{p} 23$ & $\mathrm{p} 24.1$ & $\mathrm{p} 24.2$ \\
\hline caminha esporte & 0,00 & & & & & & \\
caminha lazer & 0,00 & 0,00 & & & & & \\
caminha compras & 0,04 & 0,75 & 0,00 & & & & \\
caminha alimentação & $-0,91$ & $-1,04$ & 0,64 & 0,00 & & & \\
frequência caminha & 0,87 & $-0,55$ & $-1,88$ & 1,21 & 0,00 & & \\
caminha trabalho & 1,11 & 0,34 & 0,13 & $-0,30$ & $-0,21$ & 0,00 & \\
caminha estudo & 0,15 & 1,32 & 0,29 & $-1,15$ & 0,69 & 0,01 & 0,00 \\
\hline
\end{tabular}

\section{d) Confiabilidade do instrumento}

Os testes de Alfa de Cronbach, para os dois fatores isolados e para o instrumento completo, são exibidos pela Tabela 5.17. O instrumento completo é o de maior índice de confiabilidade, isso significa que esse instrumento não deve ser reduzido, suprimindo algum indicador e proporcionará melhores resultados com os dois fatores juntos.

Tabela 5.17 - Valores do Teste de Alfa de Cronbach para os construtos dos hábitos de transporte.

\begin{tabular}{l|l|c|c|c|c|c}
\hline \multicolumn{1}{c|}{ CONSTRUTO } & INDICADORES & \multicolumn{3}{|c|}{$\begin{array}{c}\mathrm{N} \\
\text { Válidos }\end{array}$} & $\begin{array}{c}\alpha \\
\text { Excluídos }\end{array}$ & Total \\
CRONBACH & $\begin{array}{c}\mathrm{N}^{\circ} \\
\text { Itens }\end{array}$ \\
\hline Caminha rotina & $\begin{array}{l}\mathrm{p} 23, \mathrm{p} 24.1, \\
\mathrm{p} 24.2, \mathrm{p} 24.3 \mathrm{e} \\
\mathrm{p} 24.4\end{array}$ & 408 & 0 & 408 & 0,74 & 5 \\
\hline Caminha escolha & $\mathrm{p} 24.5 \mathrm{e} \mathrm{p} 24.6$ & 408 & 0 & 408 & 0,57 & 2 \\
\hline $\begin{array}{l}\text { Instrumento } \\
\text { completo }\end{array}$ & $\mathrm{p} 23$ e p24 & 408 & 0 & 408 & 0,75 & 7 \\
\hline
\end{tabular}

a. Exclusão por método listwise com base em todas as variáveis do procedimento.

\subsubsection{Fatores gerais que influenciam o comportamento durante a travessia}

A partir dos resultados obtidos pela aplicação do questionário da terceira etapa do método, foi analisado cada uma das seis partes composta pelos seis instrumentos de pesquisa. Após essa primeira análise, de forma isolada para cada instrumento e cujos resultados foram discutidos nos itens anteriores, foram realizados testes para o instrumento completo.

Infelizmente não foram obtidos resultados interessantes para os tratamentos estatísticos feitos em conjunto com a primeira parte do questionário, que investiga o perfil predominante 
do pedestre e as conformidades espacial, temporal e com o sistema de trânsito. Como já foi dito anteriormente, os resultados dessa primeira parte do questionário refletem as observações feitas no campus e registradas em filmes, mas não constituem indicadores capazes de explicar os fatores latentes de comportamento de travessia sozinho, em grupo de desconhecidos e em companhia de alguma pessoa conhecida, no momento de aproximação da faixa e durante a travessia.

Isolando a primeira parte do questionário, as outras cinco partes constituídas pelos instrumentos analisados nos itens anteriores foram, juntamente com as caraterísticas individuais coletadas pela sexta parte, foram testadas em conjunto para a identificação dos fatores que mais se relacionam com o comportamento do pedestre nas faixas de travessia não semaforizada. A seguir são apresentados os resultados da sequência de testes utilizados para análise do instrumento, denominado de fatores gerais, e da matriz de resultados.

\section{a) Fatorabilidade da matriz}

A Tabela 5.18 apresenta os valores do índice KMO e do Teste de Esfericidade de Bartlett. A fatorabilidade da matriz para o teste KMO é considerada razoável, sendo a significância do Teste de Esfericidade de Bartlett menor que 0,05.

Tabela 5.18- KMO e Teste de Esfericidade de Bartlett - fatores gerais.

\begin{tabular}{l|l|r}
\hline Medida Kaiser-Meyer-Olkin de adequação de amostragem. & 0,70 \\
\hline Teste de esfericidade de Bartlett & Aprox. Qui-quadrado & 5428,09 \\
\cline { 2 - 3 } & gl & 903 \\
\cline { 2 - 3 } & Sig. & 0,00 \\
\hline
\end{tabular}

\section{b) Análise fatorial exploratória - AFE}

A 5.24 mostra o gráfico do teste scree plot, onde, através de uma avaliação subjetiva da inclinação da reta de fundo, pode-se perceber a incidência de oito fatores não triviais composto pelos 43 indicadores envolvidos na análise. Mas, conforme foi esclarecido no item 4.5.1, a determinação do número de componentes ou fatores a extrair é provavelmente a decisão mais importante que um investigador, executando análise fatorial, tomará. E, a ocorrência de erros nesta fase afetará a interpretação de todos os resultados subsequentes e suas estruturas fatoriais. Por isso, optou-se por trabalhar uma análise de três fatores, pois esta pareceu ser a melhor escolha passível de justificativa embasada na literatura. 


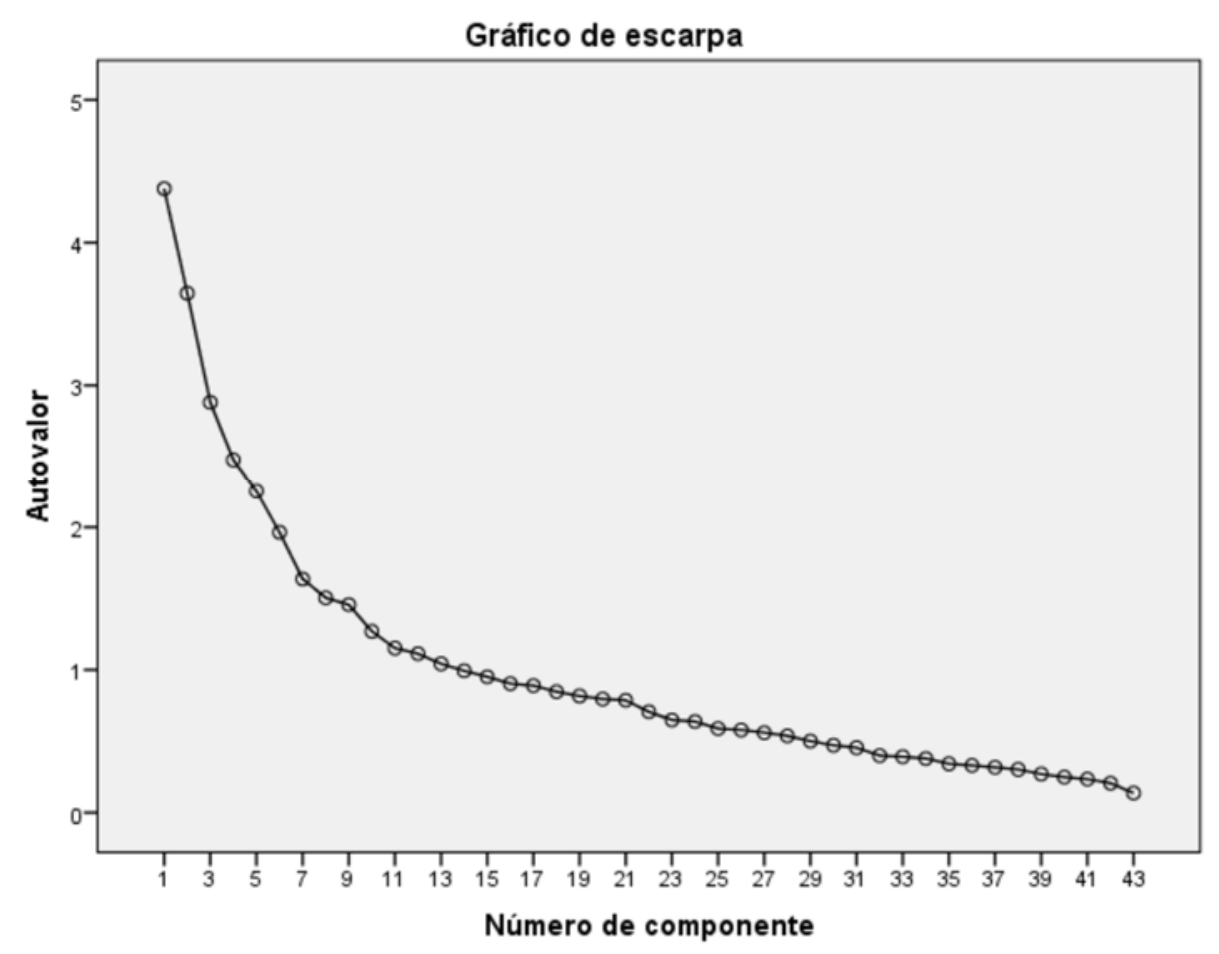

Figura 5.24 - Scree plot dos autovalores dos indicadores dos fatores gerais.

A Tabela 5.19 traz a matriz de covariância residual das vinte e três variáveis distribuídas em três construtos latentes: "travessia favorável”, "hábito de caminhar" e "travessia desfavorável”. Na extração dos fatores, foi fixado um valor mínimo de 0,40 para a carga fatorial de cada indicador.

O instrumento geral, que une os instrumentos das partes II a VI, somando 43 variáveis, foi reduzido a 23 variáveis, distribuídas nos três fatores citados acima. Esses fatores são compostos pelos indicadores constantes nos instrumentos histórico de utilização da faixa (parte III), ambiente de travessia (parte IV) e hábitos de transporte (parte V). Nenhum outro indicador, de qualquer outro instrumento, apresentou carga fatorial acima da mínima estabelecida como válida. 
Tabela 5.19 - Matriz de componente rotativa ${ }^{\mathrm{a}}$ dos indicadores dos fatores gerais.

\begin{tabular}{|c|c|c|c|}
\hline \multirow[b]{2}{*}{ INDICADOR } & \multicolumn{3}{|c|}{ COMPONENTE } \\
\hline & $\begin{array}{c}\text { TRAVESSIA } \\
\text { FAVORÁVEL }\end{array}$ & $\begin{array}{l}\text { HÁBITO DE } \\
\text { CAMINHAR }\end{array}$ & $\begin{array}{c}\text { TRAVESSIA } \\
\text { DESFAVORÁVEL }\end{array}$ \\
\hline placa sinalizacao & 0,670 & & \\
\hline pintura da faixa & 0,643 & & \\
\hline motorista me ve & 0,629 & & \\
\hline vejo veiculos & 0,592 & & \\
\hline dia & 0,589 & & \\
\hline poucos veiculos & 0,546 & & \\
\hline controle de velocidade & 0,540 & & \\
\hline perto trabalho escola & 0,490 & & \\
\hline perto casa & 0,472 & & \\
\hline morar lugar respeita & 0,415 & & \\
\hline caminha estudo & & 0,729 & \\
\hline caminha alimentacao & & 0,670 & \\
\hline caminha compras & & 0,656 & \\
\hline caminha trabalho & & 0,639 & \\
\hline frequencia caminha & & 0,591 & \\
\hline caminha lazer & & 0,510 & \\
\hline caminha esporte & & 0,427 & \\
\hline carros e motos & & & 0,702 \\
\hline onibus e caminhoes & & & 0,688 \\
\hline local congestionado & & & 0,621 \\
\hline bicicletas & & & 0,604 \\
\hline noite & & & 0,536 \\
\hline carros estacionados & & & 0,470 \\
\hline
\end{tabular}

Método de Extração: Análise de Componente Principal.

Método de Rotação: Varimax com Normalização de Kaiser.

a. Rotação convergida em 5 iterações.

\section{c) Modelagem por equação estrutural-MEE}

A Figura 5.25 apresenta o modelo da análise fatorial confirmatória e os índices de ajustes.

Pode-se observar que os três fatores apresentam baixa correlação entre si mas, mesmo assim, os melhores índices foram obtidos para o modelo que apresenta essas correlações. Os índices de ajuste de modelo não se adequam totalmente aos parâmetros especificados pela Tabela 4.5. O índice NFI (Normed Fit Index), que faz a comparação entre o modelo hipotético e o modelo independente, varia entre 0 e 1 , considerando-se um bom ajuste valores maiores que 0,90, não atingiu um valor considerado para um bom ajuste. O SRMR, que representa a média dos resíduos padronizados, e considera um bom ajuste para valores mais próximos de zero, também excede o valor máximo de 0,05. A Tabela 5.20 apresenta a matriz de covariância residual padronizada das vinte e três variáveis desta composição. 


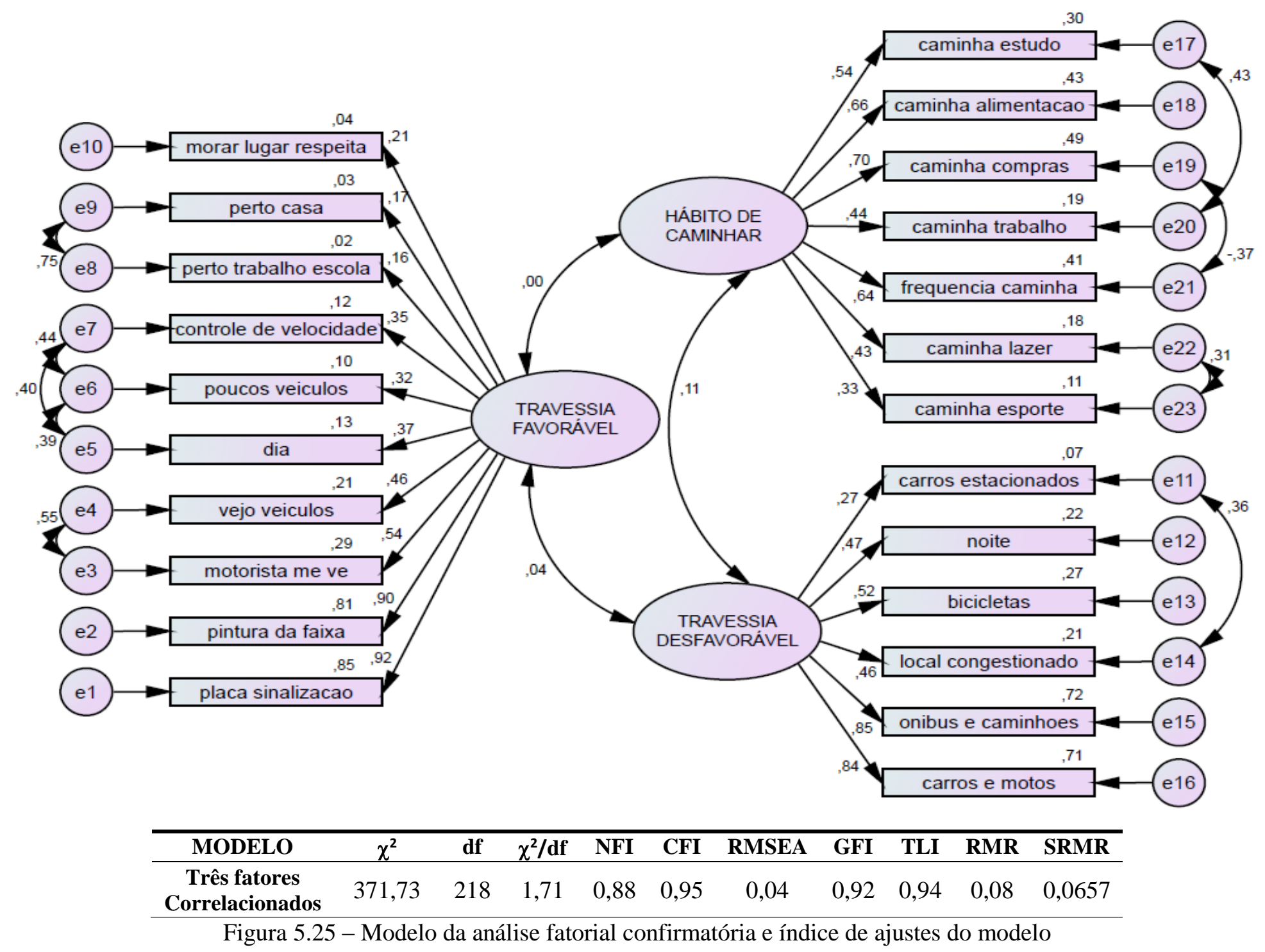


Tabela 5.20 - Matriz de covariância residual das vinte e três variáveis.

\begin{tabular}{|c|c|c|c|c|c|c|c|c|c|c|c|c|c|c|c|c|c|c|c|c|c|c|c|}
\hline & $\stackrel{n}{\stackrel{n}{2}}$ & 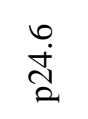 & $\stackrel{\widehat{\Omega}}{2}$ & 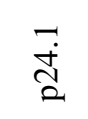 & $\underset{\stackrel{J}{d}}{\stackrel{+}{d}}$ & 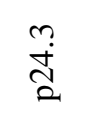 & 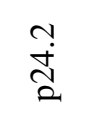 & $\stackrel{\text { ㄱ. }}{2}$ &  & $\frac{0}{\stackrel{0}{2}}$ & $\frac{a}{\check{2}}$ & $\begin{array}{l}\stackrel{n}{\vec{d}} \\
\stackrel{2}{2}\end{array}$ & $\frac{n}{\widetilde{n}}$ & 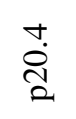 & 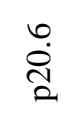 & 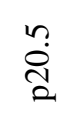 & 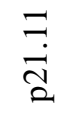 &  & $\begin{array}{l}\text { I } \\
\stackrel{\vec{C}}{2}\end{array}$ & $\underset{\check{\Sigma}}{\stackrel{+}{\Sigma}}$ & $\stackrel{n}{\stackrel{n}{2}}$ & 䒕 & $\frac{\stackrel{\sim}{\pi}}{\Omega}$ \\
\hline $\mathrm{p} 24.5$ &, 00 & & & & & & & & & & & & & & & & & & & & & & \\
\hline p24.6 & ,00 & ,00 & & & & & & & & & & & & & & & & & & & & & \\
\hline $\mathrm{p} 23$ &, 38 & $-1,02$ &, 00 & & & & & & & & & & & & & & & & & & & & \\
\hline p24.1 & 1,38 &, 83 &,- 67 & ,00 & & & & & & & & & & & & & & & & & & & \\
\hline p24.4 &,- 33 & ,46 &, 00 & ,07 & ,00 & & & & & & & & & & & & & & & & & & \\
\hline $\mathrm{p} 24.3$ &,- 63 &,- 48 &, 36 & ,30 & ,05 & ,00 & & & & & & & & & & & & & & & & & \\
\hline $\mathrm{p} 24.2$ &, 40 & 1,82 &, 00 & ,00 &,- 18 &,- 57 & ,00 & & & & & & & & & & & & & & & & \\
\hline p21.7 &, 51 &,- 08 & ,66 &, 01 & $-1,60$ & $-1,87$ & 1,34 &, 00 & & & & & & & & & & & & & & & \\
\hline $\mathrm{p} 21.8$ & 1,26 & ,28 & 1,40 & ,11 &,- 22 & $-1,57$ & 1,13 &, 11 &, 00 & & & & & & & & & & & & & & \\
\hline p21.6 &, 26 & ,93 &, 18 & ,04 & $-1,64$ &,- 37 & ,42 &,- 25 &,- 09 & ,00 & & & & & & & & & & & & & \\
\hline p21.9 &,- 96 & ,98 &, 85 &,- 57 &,- 47 & 1,00 & 1,47 &,- 01 &,- 37 & 1,22 & ,00 & & & & & & & & & & & & \\
\hline p21.13 & 1,53 & ,44 & ,95 & 2,70 & 1,40 & ,61 & 2,10 &,- 26 &,- 08 & ,46 & ,59 & ,00 & & & & & & & & & & & \\
\hline $\mathrm{p} 21.5$ &,- 41 & ,16 & 1,15 & ,93 &,- 62 & ,45 & 2,56 &,- 41 &,- 18 & ,00 & 1,52 & 1,24 &, 00 & & & & & & & & & & \\
\hline $\mathrm{p} 20.4$ &,- 39 & 96 &,- 23 & $-1,36$ &,- 20 & ,78 & $-1,05$ & 1,84 & ,93 & ,42 & 2,24 & 2,22 &,- 29 & ,00 & & & & & & & & & \\
\hline p20.6 & 1,27 & 2,24 &, 67 &, 81 & 1,44 & ,68 & 1,24 & 2,11 & 2,52 &,- 03 & 3,06 & 1,84 &, 07 & 5,25 &, 00 & & & & & & & & \\
\hline p20.5 &, 45 & ,95 &, 70 &,- 27 & ,70 & 1,08 & ,98 & 2,06 & 1,47 & ,28 & 3,92 & 1,68 &, 06 & 5,79 &, 00 &, 00 & & & & & & & \\
\hline p21.11 &,- 10 &, 51 &, 44 & $-1,44$ & 1,94 & 1,70 & $-1,02$ &,- 05 &,- 56 & $-1,44$ & 2,55 & 1,71 & $-2,44$ & 2,00 & 2,79 & 3,74 & ,00 & & & & & & \\
\hline p21.10 & 2,08 & 1,03 &, 26 &,- 62 & 1,70 & 1,15 &,- 50 & $-1,11$ & $-2,08$ & $-2,93$ & 1,67 &,- 32 & $-3,33$ &, 72 & 3,10 & 3,22 & ,00 &, 00 & & & & & \\
\hline p21.12 & 1,02 &, 04 &,- 28 &,- 35 &, 34 & 1,08 & $-1,06$ & 1,24 & ,43 &,- 71 & 2,50 &, 81 & $-2,25$ & 2,33 & 3,20 & 4,11 & ,00 &, 00 &, 00 & & & & \\
\hline p21.4 &, 50 & ,35 &,- 06 &,- 91 & ,68 &,- 83 &,- 92 & ,09 & $-1,04$ &,- 82 & ,64 &,- 85 & $-3,25$ & 2,61 &, 95 & 2,21 & ,63 &, 72 & 2,30 &, 00 & & & \\
\hline $\mathrm{p} 21.3$ & ,43 & ,58 &, 40 & $-1,41$ & ,08 &,- 91 & $-1,39$ & ,42 &,- 61 & $-1,01$ &, 20 & $-1,40$ & $-2,87$ & 3,42 & 1,37 & 1,64 & 1,07 & 2,09 & 1,01 &, 00 &, 00 & & \\
\hline $\mathrm{p} 21.1$ & 1,60 & ,59 &,- 07 & ,75 & ,04 &,- 34 &,- 61 & ,41 &,- 03 &,- 87 &,- 25 & ,89 & $-2,50$ &,- 58 &,- 49 &,- 95 &,- 39 &, 01 &,- 22 &, 08 &,- 24 &, 00 & \\
\hline $\mathrm{p} 21.2$ & ,44 & ,02 &,- 14 & 1,02 & ,04 &,- 63 &, 02 &, 41 &,- 52 & $-2,10$ &,- 13 & 1,37 & $-2,89$ &,- 38 &,- 32 &,- 15 &, 01 &,- 35 &,- 22 &,- 32 &,- 09 &, 07 & ,00 \\
\hline
\end{tabular}




\section{d) Confiabilidade do instrumento}

A Tabela 5.17 mostra os resultados dos testes de Alfa de Cronbach considerando cada um dos três fatores isolados e o instrumento completo. Os valores mostram que os indicadores dos fatores isolados apresentam maior confiabilidade do que o instrumento que utiliza todos os indicadores. Esse fato indica que o instrumento deve ser revisado, abordando uma possível redução da quantidade de indicadores, aumentando assim a sua confiabilidade.

Tabela 5.21 - Valores do Teste de Alfa de Cronbach para os construtos dos fatores gerais.

\begin{tabular}{|c|c|c|c|c|c|c|}
\hline CONSTRUTO & INDICADORES & Válidos & $\begin{array}{c}\mathrm{N} \\
\text { Excluídos a }\end{array}$ & Total & $\begin{array}{c}\alpha \\
\text { CRONBACH } \\
\end{array}$ & $\begin{array}{l}\mathrm{N}^{\circ} \\
\text { Itens }\end{array}$ \\
\hline $\begin{array}{l}\text { Travessia } \\
\text { favorável }\end{array}$ & $\begin{array}{l}\text { p20.4, p20.5, p20.6, } \\
\text { p21.1, p21.2, p21.3, } \\
\text { p21.4, p21.10, p21.11 e } \\
\text { p21.12 }\end{array}$ & 408 & 0 & 408 & 0,79 & 10 \\
\hline $\begin{array}{l}\text { Hábito de } \\
\text { Caminhar }\end{array}$ & $\begin{array}{l}\text { p23, p24.1, p24.2, } \\
\text { p24.3, p24.4, p24.5 e } \\
\text { p24.6 }\end{array}$ & 408 & 0 & 408 & 0,75 & 7 \\
\hline $\begin{array}{l}\text { Travessia } \\
\text { desfavorável }\end{array}$ & $\begin{array}{l}\text { p21.5, p21.6, p21.7, } \\
\text { p21.8, p21.9 e p21.13 }\end{array}$ & 408 & 0 & 408 & 0,76 & 6 \\
\hline $\begin{array}{l}\text { Instrumento } \\
\text { completo }\end{array}$ & $\begin{array}{l}\text { Todos os indicadores } \\
\text { acima }\end{array}$ & 408 & 0 & 408 & 0,74 & 23 \\
\hline
\end{tabular}

a. Exclusão por método listwise com base em todas as variáveis do procedimento.

\section{6 "Sinal De VidA": Modelagem estatística - Método Probit}

Em determinados eventos sabe-se que existe uma variável latente $z^{*}$ que denota algo relacionado à índole, ou a boa formação do indivíduo, ou ainda a sua propensão a executar determinado comportamento. Nesse caso, de forma parametrizada pode-se afirmar que $z^{*}>0$ se o agente possui essa característica e $z^{*} \leq 0$, caso contrário. Assim sendo, é razoável a colocação de que existe um vetor de variáveis observadas $w$ que determina $z^{*}$. Portanto, a equação comportamental para o indivíduo $i$ pode ser posta do seguinte modo:

$$
z_{i}^{*}=\gamma^{\prime} w_{i}+u_{i}
$$

Enquanto a equação primária, àquela que no caso presente refere-se a probabilidade do indivíduo fazer o uso correto da faixa de pedestre, é definida por:

$$
y_{i}=\beta^{\prime} x_{i}+\varepsilon_{i}
$$


onde $y$ é observado e $x$ é o vetor de variáveis explicativas de $y$. A ideia aqui é que $U$ e $\varepsilon$ sejam correlacionados. Assumindo a hipótese que $u$ e $\varepsilon$ tenham distribuição normal bivariada com média zero e correlação $\rho$, então de acordo com Greene (1993):

$$
\begin{gathered}
E\left[y_{i} \mid y_{i}=1\right]=E\left[y_{i} \mid z_{i}{ }^{*}>0\right]=E\left[y_{i} \mid u_{i}{ }^{*}>-\gamma^{\prime} w_{i}\right]=\beta^{\prime} x_{i}+E\left[\varepsilon_{i} \mid u_{i}{ }^{*}>-\gamma^{\prime} w_{i}\right]= \\
=\beta^{\prime} x_{i}+E\left[\varepsilon_{i} \mid u_{i}{ }^{*}>-\gamma^{\prime} w_{i}\right]=\beta^{\prime} x_{i}+\rho \sigma_{\varepsilon} \lambda_{i}\left(\alpha_{u}\right)
\end{gathered}
$$

onde: $\lambda\left(\alpha_{u}\right)=\frac{\phi\left(\gamma^{\prime} w_{i} / \sigma_{u}\right)}{\Phi\left(\gamma^{\prime} w_{i} / \sigma_{u}\right)}$

Aqui $\phi$ e $\Phi$ representam respectivamente as funções de densidade e distribuição de uma normal. Portanto temos que:

$$
y_{i} \mid z_{i}^{*}>0=\beta^{\prime} x_{i}+\rho \sigma_{\varepsilon} \lambda_{i}\left(\alpha_{u}\right)+v_{i}
$$

onde $v$ é um distúrbio com média zero e variância constante.

Como já foi colocado $z^{*}$ é uma variável não observada. No entanto, em alguns casos se pode utilizar uma outra variável $z$ passível de observação que represente $z^{*}$ de modo que $P(z=1)=P\left(z^{*}>0\right)$. Conforme pode ser notado a partir de (4), a estimação imediata por Mínimos Quadrados Ordinário gera estimadores viesados para o modelo (afinal o termo “erro" dessa equação está condicionado a regra de comportamento que é diferente de zero). Uma metodologia consistente para estimação desse modelo aparece em Heckman (1979).

O objetivo agora é demonstrar que existe uma função comportamental que qualifica, ou não, o agente a fazer uso correto da faixa de pedestre. Nesse caso, essa função que descreve a formação ou "melhor índole" do agente deve ser determinada por algumas das variáveis que, possivelmente, contribuem para a formação das preferências do indivíduo. O problema aqui reside em eleger variáveis que se possam adotar como proxies de melhor índole ou formação, e ainda aquelas que seriam utilizadas como variáveis explicativas dessa. 
A tentativa que foi testada neste trabalho foi fazer uso da variável "Sinaliza com a mão antes de atravessar a faixa" como aquela que representaria algo relacionado com o melhor comportamento do indivíduo em relação ao uso adequado da faixa de pedestre. Embora possam existir críticas pela escolha dessa variável, é razoável a colocação de que aqueles indivíduos que sinalizam com a mão antes de atravessar a faixa são os que têm, a priori, o comportamento de aproximação adequado em relação ao uso da faixa, pois estariam de acordo com a primeira conformidade estipulada pelo modelo conceitual - a conformidade espacial, pelo fato de reconhecerem o espaço adequado de travessia e manifestar claramente a intenção de atravessar a via ao se aproximarem da faixa. Esse fato também é confirmado pela determinação do perfil predominante dos pedestres pesquisados. O perfil que predomina nos frequentadores do campus da UnB é o pedestre hesitante, aquele que está de acordo com a conformidade espacial, ou seja, sinaliza antes de iniciar a travessia, mas não está de acordo com a conformidade temporal, pois altera a sua velocidade de caminhada durante a travessia.

Uma vez eleita a variável dependente da equação de comportamento, a tarefa agora recai em identificar os regressores dessa equação. Nesse caso, as variáveis com maior probabilidade de explicar o uso correto da faixa pelo pedestre seriam aquelas relativas as condições referentes a própria faixa de pedestre (estado de conservação, visibilidade, etc.). Durante as estimações do modelo econométrico uma série ampla de variáveis foi adotada como variáveis de controle. Contudo, após exaustivos procedimentos estatísticos, chegou-se a um conjunto parcimonioso de variáveis que explicam o uso correto da faixa por parte dos pedestres.

A Tabela 5.22 apresenta os resultados finais de uma regressão Probit para verificar os principais determinantes do pedestre atravessar a faixa, sinalizando sua intenção de travessia. Na primeira coluna da tabela estão listadas importantes variáveis, individuais e relacionadas ao ambiente de travessia, e nas três últimas colunas aparecem o efeito dessas variáveis sobre a postura do pedestre de acenar com a mão antes de atravessar a faixa - tanto para o caso do pedestre atravessar a faixa sozinho como em grupo, ou com alguma pessoa importante para ele. 
Tabela 5.22 - Resultados do Modelo Probit para Pedestres que atravessam na faixa.

\begin{tabular}{|c|c|c|c|}
\hline \multirow{2}{*}{ VARIÁVEIS } & \multicolumn{3}{|c|}{$\begin{array}{l}\text { VARIÁVEL DEPENDENTE: } \\
\text { POSTURA CORRETA DE SINALIZAÇÃO }\end{array}$} \\
\hline & $\begin{array}{l}\text { Atravessando } \\
\text { sozinho }\end{array}$ & $\begin{array}{c}\text { Atravessando em } \\
\text { grupo }\end{array}$ & $\begin{array}{l}\text { Atravessando com } \\
\text { alguém importante }\end{array}$ \\
\hline Homem & $-0,035(-1,69)^{* * *}$ & $-0,123(-2,56)^{*}$ & $-0,022(-0,72)$ \\
\hline $\begin{array}{l}\text { Faixa com pintura } \\
\text { bem conservada }\end{array}$ & $-0,106(-1,90) * * *$ & $-0,012(-0,13)$ & $0,025(0,38)$ \\
\hline $\begin{array}{l}\text { Sinalização por } \\
\text { placas presente }\end{array}$ & $0,086(1,20)$ & $0,164(1,83)^{* * *}$ & $0,015(0,25)$ \\
\hline $\begin{array}{l}\text { Motorista com } \\
\text { visibilidade da } \\
\text { faixa }\end{array}$ & $0,063(1,60)^{* * *}$ & $0,054(0,53)$ & $0,219(1,81)^{* * *}$ \\
\hline $\begin{array}{l}\text { Pedestre na faixa } \\
\text { visível para os } \\
\text { motoristas }\end{array}$ & $0,042(1,51)$ & $0,034(1,34)$ & $-0,046(-0,67)$ \\
\hline $\begin{array}{l}\text { Carros parados } \\
\text { próximo a faixa }\end{array}$ & $-0,02(-1,43)$ & $0,074(0,97)$ & $-0,118(-2,25)^{*}$ \\
\hline Teste LR & $\begin{array}{c}\text { LR } \operatorname{chi} 2(6)= \\
10.83[0.0740]\end{array}$ & $\begin{array}{c}\mathrm{LR} \operatorname{chi} 2(6)=14.24 \\
{[0.0270]}\end{array}$ & $\begin{array}{c}\text { LR } \operatorname{chi} 2(6)= \\
11.06[0.0590]\end{array}$ \\
\hline Pseudo $\mathrm{R}^{2}$ & 0,1204 & 0,1765 & 0,1399 \\
\hline
\end{tabular}

Entre parênteses está o valor do teste t. *** significante a $10 \%$ de significância estatística;

** significante a $5 \%$; * significante a $1 \%$.

A sinalização do pedestre de sua intenção de atravessar na faixa é fundamental para que os motoristas compreendam que devem reduzir paulatinamente sua velocidade, parando antes da faixa de pedestres, e dando segurança tanto para que o pedestre atravesse quanto para que os carros que estiverem atrás tenham tempo de reduzir suas respectivas velocidades. De maneira geral, pode-se inferir que uma boa política de incentivo ao respeito e uso da faixa de pedestres implica necessariamente na boa comunicação entre pedestres e condutores de veículos. Parte importante dessa comunicação é representada pelo aceno de mão do pedestre - sinal de vida, que indica aos condutores que o pedestre tem intenção de cruzar a via na faixa.

Um importante resultado para futuras campanhas de esclarecimento é notar que homens têm, em média, uma postura mais inadequada no uso da faixa. O simples fato de ser homem diminui em $3,5 \%$ a probabilidade de se acenar antes de cruzar a faixa sozinho, reduz em 
$12,3 \%$ a probabilidade de se acenar com a mão antes de se atravessar a faixa quando se atravessa em grupo, e reduz em $2,2 \%$ quando a travessia é feita na companhia de alguém importante para o respondente.

Um resultado surpreendente refere-se ao grau de conservação da pintura das faixas de pedestres. Quando as faixas estão bem conservadas, indivíduos atravessando sozinhos têm uma probabilidade 10,6\% menor de sinalizar com as mãos sua intenção de cruzar a faixa. Resultado similar ocorre para indivíduos cruzando a faixa em grupos. Talvez isso indique por parte do pedestre uma confiança maior de que o condutor irá parar o veículo independente dele acenar antes de cruzar a faixa, pois consegue visualizar a melhor a faixa devido ao bom estado de conservação. Mas é necessário que o pedestre entenda a necessidade de ser visto pelos condutores de veículos, mesmo quando faz a travessia em uma faixa bem conservada. $\mathrm{O}$ inverso ocorre na presença de faixas bem sinalizadas, com a presença de placas indicando a presença da faixa, além da pintura. Neste caso o pedestre tem, em todos os cenários, uma probabilidade maior de acenar com as mãos para indicar seu desejo de travessia; quando realiza a travessia em grupo, essa probabilidade aumenta $16,4 \%$.

A visibilidade que o motorista tem da faixa é fundamental para estimular o pedestre a sinalizar avisando que pretende cruzá-la. De maneira objetiva, pouco adianta ao pedestre sinalizar que pretende usar a faixa se os condutores dos veículos não tiverem a visibilidade necessária desse ato. No caso de atravessar a faixa na presença de alguém importante, os pedestres têm um incremento de $21,9 \%$ na sua probabilidade de acenar quando compreendem que os condutores dos veículos são capazes de vê-lo adequadamente. Sendo assim, a implicação de política pública é clara: é fundamental que o condutor do veículo tenha visibilidade adequada da faixa de pedestre. Logo, essas devem ser implementadas em locais que favoreçam tal visibilidade. Por fim, quando o pedestre cruza a faixa na presença de alguém importante, ele se sente desmotivado de acenar antes da travessia no caso de haver muitos veículos estacionados próximos a faixa. Isso pode ser devido ao fato de que tais veículos estacionados diminuem a visibilidade dos condutores, o que desestimula o pedestre a sinalizar sua intenção de cruzar a faixa. 


\subsection{CONSIDERAÇÕES SOBRE O CAPÍTULO}

A partir da aplicação do questionário, os dados coletados foram tabulados e foram realizadas as análises estatísticas da amostra. Primeiramente, os dados foram tratados por ferramentas de estatística descritiva, com a finalidade de fazer uma caracterização básica e inicial dos resultados encontrados. Essa análise permitiu descrever o comportamento dos respondentes com relação às conformidades espacial, temporal e com o sistema de trânsito, caracterizadas pelo modelo conceitual do método. Permitiu também a identificação do perfil predominante do pedestre, através da caracterização do comportamento em relação às conformidades do modelo conceitual. O perfil "hesitante" - representado pelo pedestre que interrompe o fluxo de veículos, mas acelera ou diminui a marcha de caminhada, alterando o tempo de travessia na faixa (item 4.2.2) - é o perfil predominante do pedestre que frequenta o Campus Darcy Ribeiro.

Após essa primeira análise descritiva, foi realizada uma sequência de testes estatísticos mais aprofundados, através da verificação da fatorabilidade da matriz de dados, análise fatorial exploratória e confirmatória para embasar a modelagem por equações estruturais, e análise de escala para verificar a confiabilidade do instrumento de pesquisa. Cada instrumento que constitui as seis partes do questionário da etapa 3, foi analisado inicialmente de forma isolada.

A parte I, que busca identificar o perfil predominante do pedestre, indicou valores descritivos muito interessantes, pois os dados coletados indicaram os comportamentos registrados nas pesquisas de observação. Mas os indicadores utilizados nesse instrumento não foram capazes de explicar estatisticamente os construtos latentes que compõem o perfil de comportamento dos pedestres durante a travessia. A matriz de resultados não obteve índice de fatorabilidade pelos testes KMO e de Esfericidade de Bartlett, impedindo a realização da análise fatorial.

Os resultados da modelagem por equações estruturais de cada instrumento, analisados de forma independente, não mostraram modelos com ótimos ajustes, mesmo para o modelo com melhores resultados. Uma análise geral dos dados obtidos pelos 43 indicadores dos instrumentos contidos nas partes II a V, permitiu uma redução de dimensão para três fatores, compostos por 23 indicadores. Esses fatores são praticamente constituídos pelos indicadores 
dos instrumentos "histórico de utilização da faixa", "ambiente de travessia" e "hábitos de transporte", que obtiveram carga fatorial superior a 0,4 na análise fatorial exploratória.

Os resultados da modelagem dos dados pelo modelo não linear Probit foi importante para elencar quais variáveis exercem influência no ato do pedestre sinalizar indicando o seu desejo de travessia. Está em tramitação no congresso nacional uma lei que pretende regulamentar o "sinal de vida" (ver anexo I), tal lei ainda tem um tema controverso, que carece de discussão para elencar o real benefício de responsabilizar o pedestre por sinalizar o desejo de travessia. Mas, de qualquer forma, conhecer quais características individuais do pedestre e do ambiente de travessia aumentam ou diminuem as chances de que o pedestre sinalize para atravessar na faixa pode ser de grande utilidade para direcionar estratégias de planejamento da circulação. 


\section{CONCLUSÕES E RECOMENDAÇÕES}

A ignorância, de fato, não deve ser entendida aqui como uma ausência de saber, mas, tal como o amor e o ódio, como uma paixão do ser; porque ela pode ser, à semelhança deles, uma via em que o ser se forma...

... O fruto positivo da revelação da ignorância é o não-saber, que não é uma negação do saber, porém sua forma mais elaborada.

Lacan (1966)

Neste capítulo são discutidos os principais resultados obtidos na tese, com foco na verificação da consecução dos objetivos da pesquisa e de suas hipóteses. Também são apresentadas as dificuldades e limitações do estudo, sugestões e recomendações para a realização de futuros trabalhos e considerações gerais sobre o tema estudado.

\subsection{HiPÓteSE E OBJETIVOS DO TRABALHO}

Conforme apresentado no capítulo 1, o presente trabalho buscou testar duas hipóteses:

(i) Os pedestres podem ser categorizados por grupos de comportamentos semelhantes, que caracterizam perfis de comportamentos em relação à travessia na faixa, através de critérios de avaliação da forma de aproximação e utilização do espaço de travessia.

(ii) Fatores de comportamento individual, histórico de utilização da faixa, hábito de se deslocar a pé e fatores do ambiente de travessia exercem influência no comportamento dos pedestres ao utilizar a faixa não semaforizada.

Para testar as hipóteses estabelecidas, o objetivo geral da pesquisa foi desenvolver um método que auxilie a compreender e identificar o perfil do pedestre de uma localidade a partir do seu comportamento durante a travessia na faixa, considerando variáveis individuais e ambientais, utilizando como suporte as teorias de análise do comportamento. Considerando que o comportamento alvo do estudo é a forma de utilização da faixa de pedestres não semaforizada, durante a travessia, foram fixados os seguintes objetivos específicos:

i) Desenvolver um modelo conceitual de comportamento do pedestre durante a travessia em faixas não semaforizadas, para caracterizar o comportamento predominante dos pedestres. Esse modelo servirá como diretriz para elaborar um método de indicação do perfil do pedestre na região em que o método for aplicado. 
ii) Testar o método elaborado no Campus Darcy Ribeiro da Universidade de Brasília, no Distrito Federal, para verificar em que grau as variáveis: i) comportamentais (atitude, normas sociais, percepção de controle e intenção); ii) do comportamento histórico em relação à faixa de pedestre; iii) do hábito de andar a pé e iv) as características individuais (sexo, idade, local de moradia, tempo de residência no local, escolaridade e empregabilidade), se relacionam com o perfil do pedestre determinado pelo modelo conceitual.

O trabalho propõe, no capítulo 4, a elaboração de um método para indicar o perfil predominante do pedestre (MIPP) que circula em um local ou região dentro de um centro urbano. Esse método foi configurado em quatro etapas. $\mathrm{O}$ desenvolvimento do modelo conceitual de conformidade de travessia, idealizado na primeira etapa do método, para parametrizar a análise do comportamento durante a travessia em faixas de pedestre não semaforizadas, permitiu a separação de três momentos de avaliação: conformidade espacial, conformidade temporal e conformidade com o sistema de trânsito.

A partir da definição desse modelo, foram realizadas várias pesquisas em campo, envolvendo filmagens de travessias e entrevistas com pedestres para embasar a definição de indicadores capazes de explicar construtos latentes relacionados ao comportamento de travessia, pelos critérios da conformidade - cumprindo o primeiro objetivo específico proposto. Após a elaboração do modelo conceitual de conformidade de travessia, foram determinados os indicadores do comportamento de travessia em três situações distintas: quando o pedestre atravessa na faixa estando sozinho, na presença de um grupo de pessoas desconhecidas e acompanhado por uma pessoa conhecida. Essas situações constituem a primeira parte do questionário proposto pela terceira etapa do método.

Em sequência à definição do modelo conceitual, na segunda etapa do método, foi feito levantamento das crenças salientes, através da aplicação de um questionário aberto, de respostas livres, apresentado no apêndice I, permitiu a elaboração dos indicadores do comportamento do pedestre em relação à faixa, preconizados pela Teoria do Comportamento Planejado e adaptados do trabalho de Bamberg et al (2003), compondo o instrumento da parte II do questionário proposta na etapa 3 do MIPP. 
As partes III, IV e V do questionário que, respectivamente, correspondem aos instrumentos que analisam o histórico de utilização da faixa, ambiente de travessia e hábitos de transporte, apresentam indicadores elaborados a partir da revisão da literatura. O questionário ainda engloba questões a respeito das características socioculturais dos respondentes na sexta e última parte.

O método pronto, a partir das diretrizes do modelo conceitual e da revisão bibliográfica, foi aplicado na cidade de Brasília, durante os meses de maio e junho de 2016. Os resultados da aplicação do método sugerem que os pedestres podem sim ser caracterizados por comportamentos semelhantes, que se repetem entre indivíduos e sofrem influência da presença de outras pessoas. Essa conclusão foi embasada na análise das respostas dadas aos indicadores da primeira parte do questionário, que visa a identificação do perfil predominante do pedestre, através da análise das conformidades de travessia, confirmando a primeira hipótese de trabalho.

Os dados coletados pela aplicação do questionário, a uma amostra válida de 408 respondentes, permitiram a avaliação das variáveis que influenciam o comportamento do pedestre durante a travessia em faixas não semaforizadas. Uma sequência de testes estatísticos foi aplicada para cada um dos instrumentos que compõem o questionário da terceira etapa do método. Os resultados desses testes demonstraram que os instrumentos de pesquisa precisam ser reavaliados, pois atingiram apenas valores razoáveis na confrontação com parâmetros estatísticos.

A análise dos resultados obtidos com a aplicação do método em Brasília, confirma parcialmente a segunda hipótese de trabalho. Os fatores que compõem o histórico de utilização da faixa, hábito de se deslocar a pé e fatores do ambiente de travessia comprovaram influência no comportamento dos pedestres ao utilizar a faixa não semaforizada, mas nada pode ser dito quanto aos fatores de comportamento individual. 


\subsection{LIMITAÇÕES E RECOMENDAÇÕES PARA TRABALHOS FUTUROS}

O estudo aqui relatado apresenta várias limitações, principalmente relacionadas aos instrumentos de pesquisa que constituíram o questionário da terceira etapa do método. As análises estatísticas dos dados mostraram que os instrumentos que compõem as partes inicial e final do questionário, I e VI, respectivamente, apresentam problemas relativos aos indicadores utilizados, tanto em sua forma quanto na sua quantidade.

A primeira parte, que tenta indicar um perfil predominante para os pedestres que responderam o questionário, é falha na elaboração dos indicadores dos construtos latentes que poderiam definir os quatro tipos de perfil identificados pelo modelo conceitual. Os resultados indicaram que as questões apresentadas no questionário são capazes de descrever o comportamento dos respondentes, e desvendar o perfil predominante, mas os testes de correlação entre os itens que englobam as três situações de travessia (sozinho, em grupo e acompanhado) não apresentaram resultados robustos.

A parte que procura identificar as características socioculturais do respondente, no caso específico da aplicação realizada no Campus Darcy Ribeiro, não apresentou uma heterogeneidade capaz de possibilitar associações fortes do comportamento do pedestre com indicadores como idade ou escolaridade. É recomendada a inserção de indicadores de caracterização socioeconômica, como renda familiar e individual dos respondentes.

O instrumento que investiga o comportamento do pedestre em relação à faixa, que representa a segunda parte do questionário, deve ser acrescido de mais indicadores dos construtos de TCP para avaliar com mais propriedade a intenção do pedestre em realizar a travessia na faixa. Os instrumentos que constituem as partes III, IV e V do questionário, que confirmaram parcialmente a segunda hipótese de trabalho, se revelaram razoáveis para configurar os fatores que influenciam o comportamento. Mas ainda podem ser revistos, principalmente na tentativa de reduzir a dimensão do questionário. 


\subsection{CONSIDERAÇÕES GERAIS}

A contribuição principal deste trabalho é fomentar a discussão a respeito da inserção do pedestre no sistema de circulação e trânsito urbano através da compreensão do seu comportamento enquanto se desloca pela cidade. A revisão da literatura desvendou várias lacunas na abordagem de investigações relacionadas ao pedestre. Uma parte das pesquisas que investigam o comportamento do pedestre avalia a percepção e aceitação de riscos, outra parte se ocupa em registrar comportamentos parametrizados por critérios de características veiculares, unindo variáveis de tempo e espaço, como aceitação de brechas para travessia, sentido e velocidade de deslocamento.

É fato que estudar o comportamento dos pedestres em busca de parâmetros que caracterizem esse comportamento é uma tarefa ingrata, pela dificuldade de reduzir vários comportamentos que traduzem um mesmo indivíduo. Os resultados mostraram que o comportamento do indivíduo sofre uma influência direta da presença de outras pessoas. Esse fato assume grande importância, pois mostra a dificuldade de traduzir em critérios numéricos um tipo de comportamento que se modifica dinamicamente sob a influência de inúmeras variáveis.

A pretensão deste estudo foi identificar parâmetros para a caracterização do perfil predominante dos pedestres em uma região. A análise do sucesso do estudo pode ser feita por duas abordagens. Primeiramente, abordando uma visão de objetivo mais concreta, podese dizer que o método proposto não atingiu a sua meta de caracterizar o perfil do pedestre, através de um instrumento estatisticamente válido para identificação de construtos latentes, ou através de indicadores observados para o comportamento durante a travessia.

Mas, de outra forma, talvez mais subjetiva, o estudo desperta para o fato de que são necessárias ainda muitas abordagens de observação e indagação, no intuito de compreender o comportamento das pessoas no sistema de circulação e trânsito, possibilitando regulamentação e planejamento da circulação adaptados às condições humanas. O Código de Trânsito Brasileiro, por exemplo, traz, em seu capítulo IV que trata dos pedestres e condutores de veículos não motorizados, que o pedestre deve realizar a travessia na faixa se ela estiver localizada até uma distância de 50m da sua rota. 
Mas sabe-se que não é natural as pessoas que caminham na cidade modificarem sua rota para fazer a travessia na faixa. E, em segundo lugar, será que é possível para uma pessoa identificar, a olho nu, uma distância de 50m enquanto caminha pela cidade, para avaliar a distância da próxima faixa de travessia? Um estudo desenvolvido por Liu e Tung (2014) mostra que os pedestres não têm condições de identificar com realismo distâncias e velocidade de aproximação dos veículos. O parâmetro cognitivo utilizado antes de uma travessia é a noção de tempo gasto para concluir a travessia e uma suposição de que aquele tempo será suficiente.

Afinal, mais uma vez pedindo licença da formalidade acadêmica - pois preciso da primeira pessoa para também fazer parte desta análise - somos humanos, falhos, não parametrizáveis. Mas vivemos e gostamos de viver em sociedade, o que requer uma certa ordem. Com a maior parte da população mundial vivendo em grandes centros urbanos, ordenar a forma de convívio, principalmente em espaços coletivos, é essencial para a garantia da qualidade de vida. É importante atentar ao fato de que as regras e regulamentações de qualquer comportamento humano só serão eficientes caso se ajustem a comportamentos possíveis. Exigir que as pessoas sigam segregações e sinalizações em excesso enquanto se deslocam e realizam travessias na cidade é uma ação fadada ao fracasso. As pessoas seguem grupos, intuitivamente. Parecem se sentir mais seguras na presença de outras pessoas do que resguardadas por sinalizações e legislações. A liberdade de caminhar precisa ser resgatada, mas utilizando recursos que se adequam ao comportamento pouco cognitivo das pessoas enquanto caminham. 


\section{REFERÊNCIAS BIBLIOGRÁFICAS}

ABNT (1989). Pesquisas de Acidentes de Tráfego - NBR 10697. Associação Brasileira de Normas Técnicas. Rio de Janeiro.

AJZEN, I. (1985). "From intentions to actions: A theory of planned behavior". In: J. Kuhi e J. Beckmann (Eds.), Action-control: From cognition to behavior (pp. 11-39). Heidelberg: Springer.

AJZEN, I. (1991). The Theory of Planned Behavior. Organizational Behavior and Human Decision Processes - 50, 179-211. University of Massachusetts at Amherst. Disponível em: http://people.umass.edu/psyc661/pdf/tpb.obhdp.pdf

AJZEN, I. (2011). Behavioral interventions: Design and evaluation guided by the theory of planned behavior. In M. M. Mark, S. I. Donaldson, e B. C. Campbell (Eds.), Social psychology for program and policy evaluation (pp. 74-100). New York: Guilford.

ARIELY, D. (2008). Previsivelmente irracional: as forças ocultas que formam as nossas decisões. Rio de Janeiro: Elsevier.

ARIOTTI, P. (2006). Análise do Padrão de Comportamento de Pedestres em Travessias Semaforizadas. Dissertação submetida ao Programa de Pós-Graduação em Engenharia de Produção, Área de concentração: Sistemas de Transportes. UFRGS, Porto Alegre, fevereiro de 2006.

BAMBERG, S.; AJZEN, I. e SCHMIDT, P. (2003). Choice of travel mode in the theory of planned behavior: The roles of past behavior, habit, and reasoned action. Basic and Applied Social Psychology, 25, 175-188.

BARBOSA, G. A. C. (2010). Percepção de risco e comportamento dos pedestres: um estudo exploratório na cidade de Maceió. Dissertação (mestrado) Programa de Engenharia de Transportes - Rio de Janeiro: UFRJ/COPPE.

BARRERO, L. H., QUINTANA, L. A., SÁNCHEZ, A., FORERO, A., QUIROGA, J. E FELKNOR, S. (2013). Pedestrians' Beliefs about Road Crossing in Bogotá: Questionnaire Development. Universitas Psychologica, 12(2), 433-444.

BERKLEY (2010). Pedestrian Master Plan - City of Berkley, Revised Draft. Disponível em: Www.ci.berkeley.ca.us/pedestrian

BIERLAIRE, M.; ANTONINI, G.; WEBER M. (2003). Behavioral dynamics for pedestrians. Institute of Mathematics Swiss Institute of Technology, Lausanne (EPFL), 1015-Lausanne (Switzerland)

BOOMSMA, A. (2000). Reporting analyses of covariance structures. Structural Equation Modeling, 7, 461-483.

BURBIDGE, S.; GOULIAS, K. (2009). Active travelbehavior. Transportation Letters. Volume 1, Issue 2 (01 April 2009), pp. 147-167.

BYRNE, B. M. (2010). Structural Equation Modeling with AMOS: Basic Concepts, Aplications, and Programing ( $2^{\text {nd }}$. Ed.). New York: Routledge Academic.

CARVALHO, M.V.G.S.A. (2006). Um modelo para dimensionamento de calçadas considerando o nível de satisfação do pedestre. Tese de Doutorado, Escola de Engenharia de São Carlos, Universidade de São Paulo, São Carlos. 
CHICAGO (2011). Chicago Pedestrian Master Plan. Chicago Department of Transportation.

CHOI E.; SAYYAR, S. (2012). Urban Diversity and Pedestrian Behaviour - Refining the concept of land-use mix for walkability. Paper Ref \# 8073. Proceedings: Eighth International Space Syntax Symposium. Santiago, PUC, 2012.

CNT (1966). Código Nacional de Trânsito. Lei No 5.108, de 21 de setembro de 1966. Imprensa Nacional - Órgão do Ministério da Justiça, Brasil. Brasília DF: Brasil.

CRISP, R. J.; TURNER, R. N. (2013). Psicologia Social Essencial. São Paulo: Roca, 2013. ISBN 978-85-4120-123-0

CTB (1997). Código de Trânsito Brasileiro. Lei № 9.503, de 23 de setembro de 1997. Imprensa Nacional - Órgão do Ministério da Justiça, Brasil. Brasília DF: Brasil.

DAMÁSIO, B. F. (2012) Uso da Análise Fatorial exploratória em psicologia. Avaliação psicológica. v. 11(2), p. 213-228.

DENATRAN (1979). Departamento Nacional de Trânsito. Serviços de Engenharia: Manual de Segurança de Pedestres. Brasília, DF.

DÍAZ, E. M. (2002). Theory of planned behavior and pedestrians' intentions to violate traffic regulations. Transportation Research Part F, 5, p. 169-175.

EVANS, D.; NORMAN, P. (1998). Understanding pedestrians' road crossing decisions: An application of the theory of planned behaviour. Health Education Research, 13(4), 481-489.

FERREIRA; M.A.G., SANCHES; S.P. (2001). Índice de qualidade das calçadas - IQC. Revista dos transportes públicos- ANTP, $2^{\circ}$ trimestre, pp 47-60.

FISHBEIN, M., E AJZEN, I. (2010). Predicting and changing behavior: The reasoned action approach. New York: Psychology Press.

FRUIN, J. J. (1971). Design for pedestrians: a level-of-service concept. Highway Research Record 355, 1-15.

GEHL, J. (1996). Life between buildings: using public space. Copenhagen: Arkitektens Forlag.

GODARA, A., S. LASSARRE, A. BANOS (2007). Simulating Pedestrian-Vehicle Interaction in an Urban Network Using Cellular Automata and Multi-Agent Model. Traffic and Granular Flow'05. ISBN: 978-3-540-47640-5 (Print) 978-3-540-476412 (Online).

GOLDBERGER, A. (1991). A Course in Econometrics. Havard University Press. Cambridge, Massachusetts.

GOV.UK (2015). Rules for pedestrians (1 to 35). Disponível em (acesso em 13/03/2015) https://www.gov.uk/rulespedestrians1 to35/Print.

GREENE, W. H. (1993). "Econometric Analysis". Prentice Hall

GÜNTHER, H. (2003). Mobilidade e affordance como cerne dos Estudos Pessoa-Ambiente. Estudos de Psicologia, Universidade de Brasília.

HAIR JUNIOR, F.; ANDERSON, R. E.; TATHAM, R. L.; BLACK, W. C. (2005). Análise multivariada de dados. Porto Alegre: Bookman, 2005. 600p.

HAMED, M. M. (2001). Analysis of pedestrians_ behavior at pedestrian crossings. Safety Science, 38, 63-82. 
HAVARD, C.; WILLIS, A. (2012). Effects of installing a marked crosswalk on road crossing behavior and perceptions of the environment. Transportation Research Part F, 15, 249-260, 2012.

HCM (1985) Highway Capacity Manual. Transportation Research Board, National Academies of Science, United States.

(2000) Highway Capacity Manual. Transportation Research Board, National Academies of Science, United States.

(2010) Highway Capacity Manual. Transportation Research Board, National Academies of Science, United States.

HELBING, D.; MOLNÁR, P.; FARKAS, I. J.; BOLAY, K. (2001). Self-organizing pedestrian movement. Environment and Planning B: Planning and Design 2001, volume 28, pages 361-383. DOI: 10.1068/b2697.

HELBING, D.; TREIBER, R. (2005). Analytical investigation of oscillations in intersecting flows of pedestrian and vehicle traffic. Physical Review E 72, 046130.

HOLLAND, C.; HILL, R. (2007). Theeffect of age, gender and driver status onpedestrians' intentions to crosstheroad in riskysituations. AccidentAnalysis and Prevention 39224 237.

JACOBSEN, A. C. (2011). Microssimulação da travessia de pedestre. Programa de PósGraduação em Engenharia de Produção da Universidade Federal do Rio Grande do Sul.

JARIYASUNANT, J.; CARREL，A.; EKAMBARAM，V.; GAKER，DJ; KOTE，T.; SENGUPTA, R.; WALKER, J. L. (2011). The Quantified Traveler: Using personal travel data to promote sustainable transport behavior. University of California, Berkeley. August 30, 2011.

KADALI, B. R.; VEDAGIRI, P. (2013). Modelling pedestrian road crossing behaviour under mixed traffic condition. European Transport \Trasporti Europei (2013) Issue 55, Paper $n^{\circ} 3$, ISSN 1825-3997.

KANT, I. (1787) Crítica da Razão Pura. Tradução: J. Rodrigues de Merege. Créditos da digitalização: Membros do grupo de discussão Acrópolis (filosofia). Homepage do grupo: http://br.egroups.com/group/acropolis/

KAPARIAS, I.; BELL, M. G.H.; MIRI, A.; CHAN, C.; MOUNT, B. (2012). Analysing the perceptions of pedestrians and drivers to shared space. Transportation Research Part $\mathrm{F}$ 15 297-310. Journal home page: www.elsevier.com/locate/trf.

KHISTY, C. J. (1994). Evaluation of pedestrian facilities: beyond the level-of-service concept. Transportation Research Record 1438, 45-50.

LACAN, J. (1966). Escritos, parte VI: Variantes do tratamento-padrão (p. 360). Tradução: Vera Ribeiro. Rio de Janeiro: Zahar, 1998.

LAROS, J. A. Laros, J. A. (2004). O uso da análise fatorial: algumas diretrizes para pesquisadores. Capítulo 7, em L. Pasquali (Org.), Análise fatorial para pesquisadores (pp. 163-193). Petrópolis: Vozes.

LÉ SÉNÉCHAL-MACHADO, V.L. e TODOROV, J.C. (2007). O comportamento do brasiliense na faixa de pedestre: exemplo de uma intervenção cultural. Dissertação apresentada ao Instituto de Psicologia da Universidade de Brasília. 
LIU, R.; SILVA, J. P.C.; SECO, A. J. M. (2000). A Bi-Modal Microsimulation Tool for the Assessment of Pedestrian Delays and Traffic Management. 9th International Association of Travel Behaviour Research Conference, Gold Coast, 2000.

LIU, Y-C; TUNG, Y-C (2014). Risk analysis of pedestrians' road-crossing decisions: Effects of age, time gap, time of day, and vehicle speed. Safety Science 63, 77-82.

MAGALHÃES, M. T. Q.; RIOS, M. F.; YAMASHITA, Y. (2004). Identificação de padrões de posicionamento determinantes do comportamento dos pedestres. XVIII ANPET Congresso de Pesquisa e Ensino em Transportes, Florianópolis, Santa Catarina, Brasil.

MARGON, P. V.; TACO, P. W. G. (2014). Caracterização do comportamento de pedestres e motoristas durante a travessia de vias em faixa não semaforizada. In: Anais $18^{\circ}$ PANAM - Congresso Panamericano de Engenharia de Trânsito, Transporte e Logística. Universidade de Cantabria - Santander, Espanha, 11 a 13 de junho de 2014.

MCDONALD, R. P. E HO, M. R. (2002). Principles and practice in reporting structural equation analyses. Psychological Methods, 7, 64-82.

MONTEIRO, F. B.; CAMPOS, V. B.G. (2012). A proposal of indicators for evaluation of the urban space for pedestrians and cyclists in access to mass transit station. 15th meeting of the EURO Working Group on Transportation - EWGT. Disponível em: www.sciencedirect.com

MURALEETHARAN, T.; TAKEO, A.; TORU, H.; SEIICHI, K.; UCHIDA, K. (2004). Evaluation of Pedestrian Level-of-Service on Sidewalks and Crosswalks Using Conjoint Analysis. In: TRANSPORTATION RESEARCH BOARD ANNUAL MEETING, 83rd, Washington,D.C.

OAKLAND (2012). Pedestrian Master Plan - City of Oakland, Revised Draft. Disponível em: www.oaklandnet.com/.../pedestria

OLIVEIRA, M. K. de. (1997). Sobre diferenças individuais e diferenças culturais: o lugar da abordagem histórico-cultural. In: AQUINO, J. G. (Org.) Erro e fracasso na escola: alternativas teóricas e práticas. São Paulo: Summus. books.google.com.br

OLIVEIRA, M. K. de; REGO, T. C. (2003). Vygotsky e as complexas relações entre cognição e afeto. In: ARANTES, V. A. (Org.) Afetividade na escola: alternativas teóricas e práticas. São Paulo: Summus. books.google.com.br

OPAS (2013). Segurança de pedestres: Manual de segurança viária para gestores e profissionais da área. Organização Pan-Americana de saúde. Brasília, DF.

PAPADIMITRIOU, E.; YANNIS, G.; GOLIAS, J. (2009). A critical assessment of pedestrian behaviour models. Transportation Research Part F, 12, 242-255, 2009.

PAPADIMITRIOU, E. (2012). Theory and models of pedestrian crossing behaviour along urban trips. Transportation Research Part F, 15, 75-94, 2012.

PAPADIMITRIOU, E.; THEOFILATOS, A.; YANNIS, G.(2013). Patterns of pedestrian attitudes, perceptions and behaviour in Europe. Transportation Research Part F, 53, $114-122,2013$.

PASQUALI, L. (2012). Análise Fatorial para pesquisadores. Brasília. Ed. LabPAM Saber e Tecnologia.

PORTLAND (1998). Portland Pedestrian Plan. Office of Transportation, Engineering and Development. Pedestrian Transportation Program. 
PRETTO, C. O., A. C. JACOBSEN, H. B. B. CYBIS (2011). A multi-layer simulation model for vehicle and pedestrian. 90th Anual Meeting Transportation Research Board, v. 1. p. 1-15, Washington.

ROCHA, J. B. A. (2006). Valores, variáveis sócio demográficas e auto relatos de comportamentos no trânsito de motoristas suspensos e não suspensos de Belém e Curitiba. Tese de Doutorado em Psicologia, Universidade Federal do Pará.

ROUPHAIL, N. M. (1984). Midblock crosswalks: a user compliance and preference study. Transportation Research Board, No. 959, p.41-47.

ROSENBLOOM, T.; NEMRODOV, D.; BARKAN, H. (2004). For Heaven's Sake Follow the Rules: Pedestrians Behavior in an Ultra-Orthodox and a Non-Orthodox City. Transportation Research Part F, 7, 395-404.

ROZESTRATEN, R. J. A. (1988). Psicologia do trânsito: conceitos e processos básicos. São Paulo: EPU e Edusp.

SANT'ANNA, R. M. (2006). Mobilidade e segurança no trânsito da população idosa: um estudo descritivo sobre a percepção de pedestres idosos e de especialistas em engenharia de tráfego. VIII, 195 p. 29,7 cm. Tese de Doutorado em Engenharia de Transportes - Universidade Federal do Rio de Janeiro, COPPE.

SANZ, A. (2012). De peatones a ciudadanos. Movilidad, texto/informe publicado em 15/10/2012. Disponível em: http://tiempodeactuar.es/blog/de-peatones-aciudadanos/, acessado em 02/09/2013.

SCHWARTZ, S. H. (1994). Are there universal aspects in the structure and contents of human values? Journal of Social Issues, 50, 19-45.

SISIOPIKU, V. P.; AKIN, D. (2000). Pedestrian Crossing Compliance: Estimation Methods and Behavioral Analysis. 2000. Institute of Transportation Engineers 70th Annual Meeting, August 6-9, 2000, Nashville, Tennessee, USA.

SISIOPIKU, V. P.; AKIN, D. (2003). Pedestrian Behaviors at and Perceptions Towards Various Pedestrian Facilities: an Examination Based on Observation and Survey Data. Transportation Research Part F, No. 6, p. 249-274.

SISIOPIKU, V. P.; AKIN, D. (2007). Pedestrian crossing compliance characteristics atgrade signalized crosswalks: Case study in a downtown-university campus environment. In: 86th Annual Meeting of Transportation Research Board, 21-27 January 2007, Washington, D.C

SUN, D.; UKKUSURI, S. V. S. K.; BENEKOHAL, R. F.; WALLER, S. T. (2003). Modeling of motorist-pedestrian interaction at uncontrolled mid-block crosswalks. In: TRANSPORTATION RESEARCH BOARD 82th ANNUAL MEETING, 2003, Washington D.C.: TRB, 2003. DVD-ROM.

THERAKOMEN, P. (2001). The Experiments for Exploring Dynamic Behaviors in Urban Places. Thesis submitted in partial fulfillment of the requirements for the degree of Master of Architecture. Department of Architecture, University of Washington, USA.

THIELEN, I. P.; HARTMANN, R. C.; SOARES, D. P. (2008). Percepção de risco e excesso de velocidade. Cad. Saúde Pública, Rio de Janeiro, 24(1):131-139.

THOMPSON, B. (2004). Exploratore and confirmatory factor anlysis: understanding concepts and applications. American Psychological Association, Washington, DC. ISBN 1-59147-093-5. 
TOM, A.; GRAINÉ, M-A. (2011). Gender differences in pedestrian rule compliance and visual search at signalized. Accident Analysis and Prevention 43, 1794-1801, 2011.

TORRES, C. V.; NEIVA, E. R. e cols. (2011). Psicologia social. Principais temas e vertentes. Artmed Ed. S.A. p. 204-218.

VASCONCELLOS, E. A. (2000). Transporte urbano nos países em desenvolvimento: reflexões e propostas. $3^{\mathrm{a}}$ edição, Editora Annablume São Paulo.

VELDE, A., J. KAMP, J. BARELA, G. SAVELSBERGH (2005). Visual timing and adaptive behavior in a road-crossing simulation study. Accident Analysis and Prevention 37 (2005) 399-406.

VELLOSO, M. S. (2014). Estudo dos fatores intrínsecos e ambientais que afetam o comportamento do condutor em relação ao respeito à velocidade limite em vias urbanas. Tese de Doutorado - Universidade de Brasília. Faculdade de Tecnologia. Departamento de Engenharia Civil e Ambiental.

WERBERICH, B. R.; PRETTO, C. O.; CYBIS, H. B. B. (2012). Análise e simulação de comportamento de pedestres em momento de travessia. In: Anais $17^{\circ}$ PANAM Congresso Panamericano de Engenharia de Trânsito, Transporte e Logística. Universidade dos Andes - Santiago, Chile, 24 a 27 de setembro de 2012.

XU, Y.; YONGJUAN, L.; ZHANG, F. (2013). Pedestrians' intention to jaywalk: Automatic or planned? A study based on a dual-process model in China. Accident Analysis and Prevention 50, 811-819.

YANG, J., W. DENG, J. WANG, Q. LI, Z. WANG (2006) Modeling pedestrians road crossing behavior in traffic system micro-simulation in China. Transportation Research Part A, v. 40, p. 280-290.

ZEGEER, C. V.; STEWART, J. R.; HUANG, H. H. E LAGERWEY, P. A. (2002). Safety effects of marked vs. unmarked crosswalks at uncontrolled locations: executive summary and recommended guidelines. FHWA-RD-01-075, Final Report. Federal Highway Administration and University of North Carolina, Highway Safety Research Center, Chapel Hill, NC 27599, USA.

ZHOU, R.; HORREY, W. J.; YU, R. (2009). The effect of conformity tendency on pedestrians' road-crossing intentions in China: An application of the theory of planned behavior. AccidentAnalysisandPrevention 41, 491-497. 


\begin{abstract}
APÊNDICE I
Questionário aberto APlicado Para leVantamento das CrenÇas SAlientes

Você está sendo convidado a participar do questionário piloto da pesquisa "COMPORTAMENTO DE PEDESTRES DURANTE A TRAVESSIA EM FAIXAS NÃO SEMAFORIZADAS", de responsabilidade de Patrícia Vilela Margon, aluna de doutorado da Universidade de Brasília. Por favor, tome 10 minutos do seu tempo para nos escrever o que você pensa sobre a possibilidade de fazer a travessia de ruas de forma segura, em faixas de pedestres não semaforizadas, considerando os critérios listados abaixo:

\footnotetext{
$\checkmark$ atravessar no espaço delimitado pela faixa de pedestres;

$\checkmark$ sinalizar para os veículos antes de começar a travessia;

$\checkmark$ manter uma marcha constante durante a travessia;

$\checkmark$ observar os veículos durante todo o tempo de travessia;

$\checkmark$ não fazer uso de celulares e

$\checkmark$ não fazer uso fones de ouvido durante a travessia.
}

O objetivo da pesquisa é elaborar um método de identificação do perfil predominante dos pedestres em uma determinada região, e poder auxiliar os órgãos públicos de trânsito, para que estes possam adotar medidas educativas que sejam eficazes, a partir do conhecimento do comportamento do pedestre durante a travessia.

Sua participação é voluntária e livre de qualquer remuneração ou benefício. Você é livre para recusar-se a participar, retirar seu consentimento ou interromper sua participação a qualquer momento. A recusa em participar não irá acarretar qualquer penalidade ou perda de benefícios. Há 7 perguntas neste questionário

Se você tiver qualquer dúvida em relação à pesquisa, você pode me contatar pelo e-mail patricia.margon@gctnt.org. Obrigada! 


\section{Resultados comportamentais}

Não há respostas certas ou erradas; estamos apenas interessados em suas opiniões pessoais. Em resposta às perguntas abaixo, por favor, liste os pensamentos que vêm imediatamente à mente. Escreva cada pensamento em uma linha separada.

1. O que você vê como vantagem de atravessar a rua de forma segura, utilizando a faixa de pedestres não semaforizada?

2. O que você vê como desvantagem de atravessar a rua de forma segura, utilizando a faixa de pedestres não semaforizada?

3. O que mais vem à sua mente quando você pensa sobre atravessar a rua de forma segura, utilizando a faixa de pedestres não semaforizada?

\section{Referentes normativos}

Quando se trata de atravessar a rua de forma segura, na faixa de pedestres não semaforizada, pode haver indivíduos ou grupos que iriam pensar que você deve ou não realizar esse comportamento.

4. Por favor, liste os indivíduos ou grupos que iriam aprovar o seu pensamento de atravessar a rua de forma segura, na faixa de pedestres não semaforizada (amigos, família, companheiro(a), colegas de estudo ou trabalho).

5. Por favor, liste os indivíduos ou grupos que desaprovariam ou pensam que você não deve atravessar a rua de forma segura, na faixa de pedestres não semaforizada.

\section{Fatores de controle}

6. Por favor, liste quaisquer fatores ou circunstâncias que tornam mais fácil ou the permitam atravessar a rua, na faixa de pedestres não semaforizada, de forma segura.

7. Por favor, liste quaisquer fatores ou circunstâncias que dificultam ou impedem de atravessar a rua, na faixa de pedestres não semaforizada, de forma segura. 


\section{APÊNDICE II}

QUESTIONÁRIO APLICADO PARA LEVANTAMENTO DAS VARIÁVEIS DE ESTUDO 


\section{Comportamento do pedestre}

Olá, como vai?

Você sabia que a melhor forma para planejar a mobilidade e o trânsito de um local é conhecer o comportamento das pessoas enquanto elas se deslocam? Por isso, eu quero te convidar para relembrarmos o seu comportamento como pedestre e, para tal, preciso que você responda algumas questões.

A finalidade da pesquisa é tentar compreender o seu comportamento como pedestre, durante a travessia na faixa não semaforizada, ou seja, aquela que não possui nenhum dispositivo a ser acionado para avisar aos motoristas da travessia de pessoas. Trata-se de uma pesquisa de doutorado, de minha responsabilidade, como aluna do Programa de PósGraduação em Transportes (PPGT) da Universidade de Brasília.

As suas respostas serão baseadas nas recordações de como você habitualmente se comporta quando utiliza a faixa de pedestres para fazer a travessia das ruas. Não existem respostas certas ou erradas. Para cada questão marque uma única alternativa, a que melhor descreva o seu comportamento.

Obrigada por participar! Patrícia Vilela Margon.

\section{IDENTIFICAÇÃO DO PERFIL}

Esta etapa inicial do questionário busca identificar o seu perfil de comportamento durante uma travessia. Peço que você imagine uma travessia para chegar a um local que você vá com frequência no Campus Darcy Ribeiro da UnB.
A partir dessa situação imaginada, você identificará a opção que mais representa o seu comportamento na travessia, em três contextos diferentes:

1) atravessando sozinho;

2) atravessando com um grupo de pessoas desconhecidas

3) atravessando acompanhado de alguém importante para você

\section{Você vai atravessar na faixa de pedestres e ESTÁ SOZINHO...}

Por favor, leia todas as alternativas e escolha apenas uma resposta.

1. No momento de iniciar a travessia, você se posiciona em frente à faixa de pedestres para iniciar a travessia e...

acena com a mão, indicando para os motoristas que quer atravessar

O espera surgir um espaço entre os veículos para atravessar a rua

2. Você já começou a atravessar a rua, está na faixa de pedestres andando...

mais rápido do que costuma caminhar

O na sua velocidade normal de caminhada

distraidamente

3. Enquanto atravessa a rua, você...

observa atentamente o movimento dos veículos, até concluir a travessia

O continua o que estava fazendo antes de começar a atravessar (ouvindo música, verificando mensagens ou falando no celular)

O direciona o olhar para o ponto final da travessia 


\section{Você vai atravessar na faixa de pedestres e ESTÁ PRÓXIMO A UM GRUPO de pessoas desconhecidas.}

4. No momento de iniciar a travessia, você se posiciona em frente à faixa de pedestres para iniciar a travessia e...

espera para iniciar a travessia junto com as pessoas do grupo

acena para os carros e começa a travessia

começa a atravessar logo depois que o grupo iniciou a travessia

começa a travessia independente do grupo

5. Você já começou a atravessar a rua, está na faixa de pedestres andando...

junto com o grupo, na mesma velocidade de caminhada das outras pessoas

rapidamente, se afastando do grupo

normalmente, na sua velocidade, independente do grupo

permanece logo atrás do grupo, caminhando mais devagar que as outras pessoas

6. Enquanto atravessa a rua, você...

observa atentamente o movimento dos veículos, até concluir a travessia

observa os movimentos das pessoas do grupo

continua o que estava fazendo antes de começar a atravessar (ouvindo música, verificando mensagens ou falando no celular)

mantém o foco no ponto final da travessia
Você vai atravessar na faixa de pedestres e ESTÁ ACOMPANHADO de uma pessoa importante para você (pai, mãe, filho(a), companheiro(a), amigo(a))...

7. No momento de iniciar a travessia, você se posiciona em frente à faixa de pedestres para iniciar a travessia e...

O espera surgir um espaço entre os veículos para atravessar a rua

acena com a mão, indicando para os motoristas que quer atravessar

começa a travessia seguindo os movimentos de quem te acompanha

8. Você já começou a atravessar a rua, está na faixa de pedestres andando...

O normalmente, na sua velocidade

na mesma velocidade da pessoa que te acompanha

O distraidamente

rapidamente

9. Enquanto atravessa a rua, você...

observa atentamente o movimento dos veículos, até concluir a travessia

conversa com a pessoa que te acompanha

fica atento(a) ao ponto final de travessia

fica atento(a) aos movimentos da pessoa que te acompanha

10. Você se imaginou na companhia de quem?

pai ou mãe

avô ou avó

filho(a)

algum outro parente

O companheiro(a)

O amigo(a) 


\section{UNIVERSIDADE DE BRASÍLIA}

O mapa do Campus Darcy Ribeiro, apresentado abaixo, indica a localização das principais faixas de pedestres de acesso e circulação no campus. As faixas estão numeradas e marcadas por um círculo vermelho. Observe o mapa e identifique os locais que você frequenta no campus...

11. Com o auxílio do mapa, indique qual faixa de pedestre do campus mais representa o local onde você imaginou a sua travessia?



Faixa número:

\section{COMPORTAMENTO EM RELAÇÃO A TRAVESSIA NA FAIXA}

Nesta etapa, as respostas serão um valor escolhido em uma escala entre dois adjetivos que variam de uma questão para outra. Veja o exemplo abaixo:

Para mim, contribuir com uma pesquisa sobre a travessia na faixa de pedestres é:

$\begin{array}{lllllll}1 & 2 & 3 & 4 & 5 & 6 & 7\end{array}$

\section{Positivo $\bigcirc \bigcirc \bigcirc \bigcirc \bigcirc \bigcirc \bigcirc$ Negativo}

Marque:

1 = se você considera muito positivo

2 = se você considera positivo

3 = se você não tem certeza se é positivo

4 = se você não tem uma opinião formada a respeito

5 = se você não tem certeza se é negativo

$6=$ se você considera negativo

7 = se você considera muito negativo

Para responder as perguntas a seguir, tenha em mente um caminho que você faz com frequência no campus. 
Utilizar a faixa de pedestres da próxima vez que eu for atravessar a rua é...

12. ... segundo a adequabilidade:

$\begin{array}{lllllll}1 & 2 & 3 & 4 & 5 & 6 & 7\end{array}$

Adequado $\bigcirc \bigcirc \bigcirc \bigcirc 0 \bigcirc \bigcirc$ Inadequado

13. ... segundo a agradabilidade:

$\begin{array}{lllllll}1 & 2 & 3 & 4 & 5 & 6 & 7\end{array}$

Desagradável $\bigcirc \bigcirc \bigcirc \bigcirc \bigcirc \bigcirc \bigcirc$ Agradável

14. A maioria das pessoas que são importantes para mim apoiaria que eu atravessasse na faixa.

$$
\begin{array}{lllllll}
1 & 2 & 3 & 4 & 5 & 6 & 7
\end{array}
$$

Provável $\bigcirc \bigcirc \bigcirc \bigcirc \bigcirc \bigcirc \bigcirc$ Improvável

15. A maioria das pessoas que são importantes para mim pensa que eu deveria atravessar na faixa.

$\begin{array}{lllllll}1 & 2 & 3 & 4 & 5 & 6 & 7\end{array}$

Provável $\bigcirc \bigcirc \bigcirc \bigcirc 0 \bigcirc \bigcirc$ Improvável
16. Para mim, atravessar na faixa para chegar ao meu trabalho, ou local de estudo, da próxima vez seria *

$\begin{array}{lllllll}1 & 2 & 3 & 4 & 5 & 6 & 7\end{array}$

Fácil $\bigcirc \bigcirc \bigcirc \bigcirc \bigcirc \bigcirc \bigcirc$ Difícil

17. Minha liberdade de atravessar na faixa para chegar ao meu trabalho, ou local de estudo, na próxima vez é *

$\begin{array}{lllllll}1 & 2 & 3 & 4 & 5 & 6 & 7\end{array}$

Baixa $\bigcirc \bigcirc \bigcirc \bigcirc \bigcirc \bigcirc \bigcirc$ Alta

18. A minha intenção de atravessar na faixa para chegar ao meu trabalho, ou local de estudo, na próxima vez é *

$\begin{array}{lllllll}1 & 2 & 3 & 4 & 5 & 6 & 7\end{array}$

Forte $\bigcirc \bigcirc \bigcirc \bigcirc \bigcirc \bigcirc \bigcirc$ Fraca

19. Tenho a intenção de atravessar na faixa na próxima vez que for ao meu trabalho, ou local de estudo. *

$\begin{array}{lllllll}1 & 2 & 3 & 4 & 5 & 6 & 7\end{array}$

Provável $\bigcirc \bigcirc \bigcirc \bigcirc \bigcirc \bigcirc \bigcirc$ Improvável 


\section{HISTÓRICO E PREFERÊNCIAS DE UTILIZAÇÃO DA FAIXA}

20. Eu atravesso a rua na faixa de pedestres...

\begin{tabular}{|c|c|c|c|c|c|}
\hline & 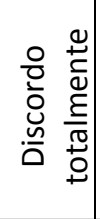 & $\begin{array}{l}\text { 음 } \\
\text { 은 } \\
\frac{\mathfrak{n}}{0}\end{array}$ & 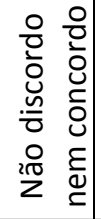 & $\begin{array}{l}\text { 은 } \\
\text { 은 } \\
\text { 어 }\end{array}$ &  \\
\hline $\begin{array}{l}\text { Desde criança, fui educado para } \\
\text { atravessar na faixa }\end{array}$ & 0 & 0 & 0 & & 0 \\
\hline $\begin{array}{l}\text { Depois de um acidente } \\
\text { (atropelamento) envolvendo a mim } \\
\text { ou pessoas conhecidas }\end{array}$ & 0 & 0 & 0 & 0 & 0 \\
\hline $\begin{array}{l}\text { Depois de ser convencido por uma } \\
\text { campanha educativa }\end{array}$ & 0 & 0 & 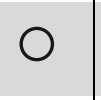 & 0 & 0 \\
\hline $\begin{array}{l}\text { Depois de morar em um lugar onde } \\
\text { motoristas e pedestres respeitam a } \\
\text { faixa }\end{array}$ & D & 0 & & & 0 \\
\hline $\begin{array}{l}\text { Quando estou próximo ao meu local } \\
\text { de trabalho e/ou estudo }\end{array}$ & P & 0 & ) & & 0 \\
\hline $\begin{array}{l}\text { Quando estou próximo do local onde } \\
\text { moro }\end{array}$ & 0 & 0 & 0 & & 0 \\
\hline $\begin{array}{l}\text { Quando me preocupo com a opinião } \\
\text { das pessoas que estão próximas a } \\
\text { mim }\end{array}$ & ) & $\bigcirc$ & ) & & 0 \\
\hline
\end{tabular}

21. Eu me sinto confortável para atravessar na faixa quando...

\begin{tabular}{|c|c|c|c|c|c|}
\hline & 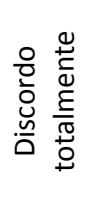 & $\begin{array}{l}\frac{0}{0} \\
\frac{\mathbf{u}}{0} \\
\frac{\mathrm{n}}{0}\end{array}$ & 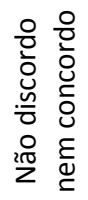 & 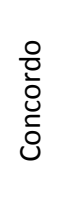 & 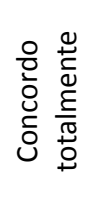 \\
\hline $\begin{array}{l}\text { A pintura da faixa está em bom } \\
\text { estado de conservação }\end{array}$ & 0 & $\cap$ & 0 & & 0 \\
\hline $\begin{array}{l}\text { As placas de sinalização estão em } \\
\text { bom estado de conservação e } \\
\text { visibilidade }\end{array}$ & 0 & & & & 0 \\
\hline $\begin{array}{l}\text { Atravesso em um local onde os } \\
\text { motoristas podem me ver }\end{array}$ & 0 & 0 & $\Omega$ & & 0 \\
\hline $\begin{array}{l}\text { Atravesso em um local onde tenho } \\
\text { uma boa visibilidade dos veículos }\end{array}$ & 0 & 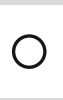 & ) & & 0 \\
\hline $\begin{array}{l}\text { Existem carros estacionados próximo } \\
\text { à faixa }\end{array}$ & $\Omega$ & & & & \\
\hline A faixa está em local congestionado & $\bigcirc$ & $\Omega$ & $\mathrm{O}$ & ) & $\bigcirc$ \\
\hline Trafegam carros e motos no local & 0 & & & & 0 \\
\hline Trafegam ônibus e caminhões & $\bigcirc$ & $\bigcirc$ & $\bigcirc$ & $\Omega$ & O \\
\hline $\begin{array}{l}\text { Atravesso em locais com ciclo faixas } \\
\text { ou ciclovias }\end{array}$ & 0 & $\Omega$ & & & $\Omega$ \\
\hline Passam poucos veículos pelo local & $\mathrm{O}$ & D & $\bigcirc$ & 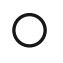 & $\bigcirc$ \\
\hline $\begin{array}{l}\text { Existem dispositivos de controle de } \\
\text { velocidade dos veículos próximos ao } \\
\text { local da faixa }\end{array}$ & 0 & & ) & & 0 \\
\hline É dia & $\bigcirc$ & $\bigcirc$ & $\bigcirc$ & $\bigcirc$ & $\bigcirc$ \\
\hline É noite & $\bigcirc$ & 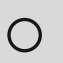 & 0 & $\bigcirc$ & $\bigcirc$ \\
\hline
\end{tabular}




\section{HÁBITOS DE TRANSPORTE}

22. Geralmente, nos meus deslocamentos de rotina, eu uso:

caminhar

$O$ bicicleta

transporte público (ônibus ou metrô)

moto

carro (motorista ou carona)

$\bigcirc$ táxi ou outro transporte fretado (escolar, empresa onde trabalha)

23. Em média, quantas vezes na semana você vai e volta andando para um lugar (ir almoçar, ao mercado, à farmácia, academia...)?

menos de 1 vez por semana

até 2 vezes por semana

de 3 a 5 vezes por semana

de 6 a 7 vezes por semana

mais de 7 vezes por semana
24. Indique a frequência que você caminha, como única forma de deslocamento, para realizar as seguintes atividades:

\begin{tabular}{|c|c|c|c|c|c|}
\hline & 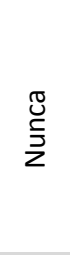 & 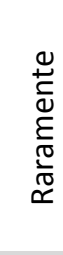 & 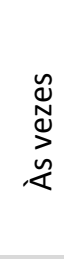 & 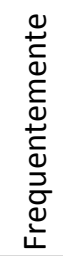 & $\begin{array}{l}\stackrel{0}{े} \\
\text { है } \\
\text { ڤ }\end{array}$ \\
\hline Trabalho & 0 & 0 & 0 & 0 & 0 \\
\hline Estudo & $\bigcirc$ & $\mathrm{O}$ & $\bigcirc$ & $\mathrm{O}$ & $\mathrm{O}$ \\
\hline $\begin{array}{l}\text { Alimentação (almoço, jantar, } \\
\text { lanches) }\end{array}$ & 0 & 0 & 0 & 0 & 0 \\
\hline Compras & $\bigcirc$ & $\bigcirc$ & $\bigcirc$ & $\bigcirc$ & 0 \\
\hline Prática de exercícios físicos & $\bigcirc$ & $\bigcirc$ & 0 & $\bigcirc$ & 0 \\
\hline Lazer & 0 & 0 & 0 & 0 & 0 \\
\hline
\end{tabular}




\section{CARACTERÍSTICAS INDIVIDUAIS}

25. Sexo:

feminino

masculino

26. Idade: anos

27. Cidade em que você mora *

Brasília

Outro:

28. Estado:

Distrito Federal

Outro:

29. Reside nessa cidade há quanto tempo? (Não necessariamente no mesmo endereço)

menos de 1 ano

menos de 5 anos

0 menos de 10 anos

menos de 20 anos

- 20 anos ou mais

30. Qual a sua escolaridade? (Leia todas as alternativas e marque apenas a que melhor corresponder ao seu nível escolar na atualidade).

Sou estudante cursando pós-graduação

Sou estudante universitário

Sou estudante do ensino médio
Sou estudante do ensino fundamental

Não sou estudante atualmente, mas concluí um curso de pósgraduação

Não sou estudante atualmente, mas concluí o ensino superior.

Não sou estudante atualmente, mas concluí o ensino médio ( 2 o grau)

$\bigcirc$ Não sou estudante atualmente, mas concluí o ensino fundamental (10 grau)

31. Você estuda na UnB?

Sim

Não

32. Qual das opções abaixo descrevem sua situação atual de trabalho (ocupação)? Marque a opção que mais se aplica à sua situação atual.

Trabalho em tempo integral - mais de 20 horas por semana

Trabalho em tempo parcial - 20 horas ou menos por semana

Estudante por tempo integral - mais de 20 horas por semana

Estudante por tempo parcial - 20 horas ou menos por semana

Desempregado(a)

33. Você Trabalha na UnB?

$\mathrm{OSim}$

Não

Obrigada por sua participação!

patmargon73@gmail.com

Grupo de Pesquisa sobre Comportamento em Transporte e Novas Tecnologias - www.gctnt.org 


\section{APÊNDICE III}

\begin{tabular}{|c|c|c|}
\hline \multicolumn{3}{|c|}{ PARTE II - COMPORTAMENTO EM RELAÇÃO A TRAVESSIA NA FAIXA } \\
\hline & NDICADOR & PERGUNTA DO QUESTIONÁRIO \\
\hline P12 & atitude 1 & $\begin{array}{l}\text { Utilizar a faixa de pedestres da próxima vez que eu for } \\
\text { atravessar a rua é... - Adequado / inadequado. }\end{array}$ \\
\hline P13 & atitude 2 & $\begin{array}{l}\text { Utilizar a faixa de pedestres da próxima vez que eu for } \\
\text { atravessar a rua é... - Agradável / desagradável. }\end{array}$ \\
\hline P14 & norma social 1 & $\begin{array}{l}\text { A maioria das pessoas que são importantes para mim apoiaria } \\
\text { que eu atravessasse na faixa - provável / improvável. }\end{array}$ \\
\hline P15 & norma social 2 & $\begin{array}{l}\text { A maioria das pessoas que são importantes para mim pensa que } \\
\text { eu deveria atravessar na faixa - provável / improvável. }\end{array}$ \\
\hline P16 & controle comp 1 & $\begin{array}{l}\text { Para mim, atravessar na faixa para chegar ao meu trabalho, ou } \\
\text { local de estudo, da próxima vez seria - fácil / difícil. }\end{array}$ \\
\hline P17 & controle comp 2 & $\begin{array}{l}\text { Minha liberdade de atravessar na faixa para chegar ao meu } \\
\text { trabalho, ou local de estudo, na próxima vez é - baixa / alta. }\end{array}$ \\
\hline P18 & intenção 1 & $\begin{array}{l}\text { A minha intenção de atravessar na faixa para chegar ao meu } \\
\text { trabalho, ou local de estudo, na próxima vez é - forte / fraca. }\end{array}$ \\
\hline P19 & intenção 2 & $\begin{array}{l}\text { Tenho a intenção de atravessar na faixa na próxima vez que for } \\
\text { ao meu trabalho, ou local de estudo - provável / improvável. }\end{array}$ \\
\hline
\end{tabular}

\begin{tabular}{l|l|l}
\hline \multicolumn{3}{c}{ PARTE III - HISTÓRICO DE UTILIZAÇÃO DA FAIXA } \\
\multicolumn{2}{c}{ INDICADOR } & \multicolumn{1}{c}{ PERGUNTA DO QUESTIONÁRIO } \\
\hline P20.1 & desde criança & Desde criança, fui educado para atravessar na faixa \\
\hline P20.2 & após acidente & $\begin{array}{l}\text { Depois de um acidente (atropelamento) envolvendo a mim ou } \\
\text { pessoas conhecidas }\end{array}$ \\
\hline P20.3 & após campanha & Depois de ser convencido por uma campanha educativa \\
\hline P20.4 & $\begin{array}{l}\text { morar lugar } \\
\text { respeita }\end{array}$ & $\begin{array}{l}\text { Depois de morar em um lugar onde motoristas e pedestres } \\
\text { respeitam a faixa }\end{array}$ \\
\hline P20.5 & $\begin{array}{l}\text { perto trabalho } \\
\text { escola }\end{array}$ & Quando estou próximo ao meu local de trabalho e/ou estudo \\
\hline P20.6 & perto casa & Quando estou próximo do local onde moro \\
\hline P20.7 & opinião pessoas & $\begin{array}{l}\text { Quando me preocupo com a opinião das pessoas que estão } \\
\text { próximas a mim }\end{array}$ \\
\hline
\end{tabular}




\begin{tabular}{l|l|l}
\hline \multicolumn{3}{c}{ Pu me sinto confortável para atravessar na faixa quando... } \\
\multicolumn{3}{c}{ PERGUNTA DO QUESTIONÁRIO } \\
\hline P21.1 & pintura da faixa & A pintura da faixa está em bom estado de conservação \\
\hline P21.2 & placa sinalização & $\begin{array}{l}\text { As placas de sinalização estão em bom estado de conservação e } \\
\text { visibilidade }\end{array}$ \\
\hline P21.3 & motorista me vê & Atravesso em um local onde os motoristas podem me ver \\
\hline P21.4 & vejo veículos & $\begin{array}{l}\text { Atravesso em um local onde tenho uma boa visibilidade dos } \\
\text { veículos }\end{array}$ \\
\hline P21.5 & $\begin{array}{l}\text { carros } \\
\text { estacionados }\end{array}$ & Existem carros estacionados próximo à faixa \\
\hline P21.6 & $\begin{array}{l}\text { local } \\
\text { congestionado }\end{array}$ & A faixa está em local congestionado \\
\hline P21.7 & carros e motos & Trafegam carros e motos no local \\
\hline P21.8 & $\begin{array}{l}\text { onibus e } \\
\text { caminhões }\end{array}$ & Trafegam ônibus e caminhões \\
\hline P21.9 & bicicletas & Atravesso em locais com ciclo faixas ou ciclovias \\
\hline P21.10 & poucos veículos & Passam poucos veículos pelo local \\
\hline P21.11 & $\begin{array}{l}\text { controle de } \\
\text { velocidade }\end{array}$ & $\begin{array}{l}\text { Existem dispositivos de controle de velocidade dos veículos } \\
\text { próximos ao local da faixa }\end{array}$ \\
\hline P21.12 & dia & É dia \\
\hline P21.13 & noite & É noite \\
\hline & &
\end{tabular}

\begin{tabular}{l|l|l}
\hline \multicolumn{3}{c}{ PARTE V - HÁBITOS DE TRANSPORTE } \\
INDICADOR & \multicolumn{1}{c}{ PERGUNTA DO QUESTIONÁRIO } \\
\hline P23 & $\begin{array}{l}\text { frequência } \\
\text { caminha }\end{array}$ & $\begin{array}{l}\text { Em média, quantas vezes na semana você vai e volta andando } \\
\text { para um lugar (ir almoçar, ao mercado, à farmácia, } \\
\text { academia...)? }\end{array}$ \\
\hline P24.1 & caminha trabalho & Indique a frequência que você caminha para trabalho \\
\hline P24.2 & caminha estudo & Indique a frequência que você caminha para estudo \\
\hline P24.3 & $\begin{array}{l}\text { caminha } \\
\text { alimentação }\end{array}$ & Indique a frequência que você caminha para alimentação \\
\hline P24.4 & caminha compras & Indique a frequência que você caminha para compras \\
\hline P24.5 & Caminha esporte & $\begin{array}{l}\text { Indique a frequência que você caminha para prática de } \\
\text { exercícios físicos }\end{array}$ \\
\hline P24.6 & Caminha lazer & Indique a frequência que você caminha para lazer \\
\hline
\end{tabular}




\begin{abstract}
ANEXO I
PROJETO DE LEI DA CÂMARA nº 26, de 2010

(http://www25.senado.leg.br/web/atividade/materias/-/materia/96396)
\end{abstract}




\section{PROJETO DE LEI DA CÂMARA n²6, de 2010}

\section{Autoria: Deputada Perpétua Almeida}

\section{Ementa:}

Altera o art. 69 e o item 6 do Anexo II - Sinalização, da Lei no 9.503, de 23 de setembro de 1997, que institui o Código de Trânsito Brasileiro, para dispor sobre a travessia de pedestres em passagem sinalizada.

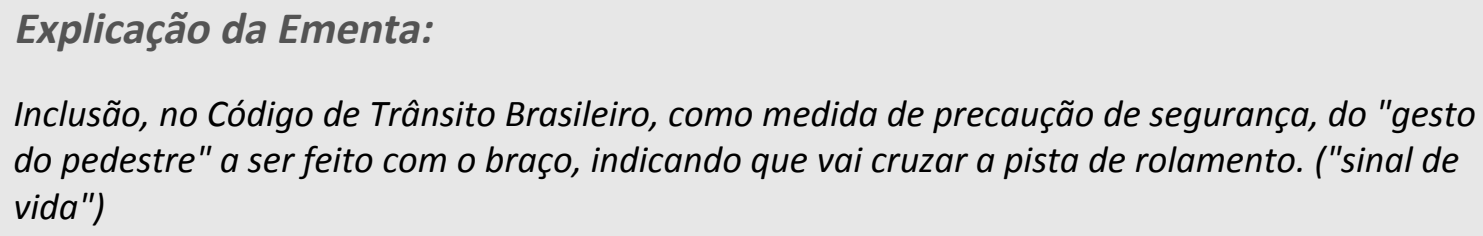

Decisão:

Último local:

04/04/2016 - Comissão de Direitos Humanos e Legislação Participativa (Secretaria de Apoio à Comissão de Direitos Humanos e Legislação Participativa)

Destino:

Último estado: 04/04/2016 - MATÉRIA COM A

Relatoria atual: Relator: Ana Amélia RELATORIA

Matérias Relacionadas:

RECURSO (SF) $n^{\circ} 10$, de 2014

REQUERIMENTO $n^{\circ}$ 682, de 2015

\section{Despacho:}

$N^{\circ} 2$ (Aprovação do Requerimento no 682, de 2015, de

(SF) CCJ - Comissão de Constituição, Justiça e Cidadania

(SF) CDH - Comissão de Direitos Humanos e Legislação Participativa

\section{$N^{\circ} 1$ (despacho inicial)}

(SF) CCJ - Comissão de Constituição, Justiça e Cidadania
Relatoria:

CCJ - (Comissão de Constituição, Justiça e Cidadania)

Relator(es):

Antonio Carlos Valadares (encerrado em 05/11/2014 - Parecer aprovado pela comissão

Lúcia Vânia (encerrado em 22/12/2010 - Fim de Legislatura

CDH - (Comissão de Direitos Humanos e Legislação Participativa)

Relator(es):

Ana Amélia

Ação: O Presidente da Comissão de Direitos Humanos e Legislação Participativa, Senador Paulo Paim, designa a Senadora Ana Amélia relatora da matéria.

O processado da matéria legislativa permanecerá na Secretaria da Comissão durante o transcurso de sua tramitação, conforme art. 6o da Instrução Normativa da Secretaria Geral da Mesa no 4 de 2015. 
11/03/2016 CDH - Comissão de Direitos Humanos e Legislação Participativa

Situação: AGUARDANDO DESIGNAÇÃO DO RELATOR

Ação: Recebido na Comissão nesta data. Matéria aguardando distribuição.

10/03/2016 SEADI - Secretaria de Atas e Diários

Ação: Aprovado o Requerimento no 682, de 2015.

Uma vez que já se encontra instruída pela CCJ, a matéria vai ao exame da CDH.

Recebido em: 11/03/2016 às 15:45 por SACDH - Secretaria de Apoio à Comissão de Direitos Humanos e Legislação Participativa

10/03/2016 SLSF - Secretaria Legislativa do Senado Federal

Ação: Encaminhado ao Plenário.

Recebido em: 11/03/2016 às 10:21 por SEADI - Secretaria de Atas e Diários

15/06/2015 SLSF - Secretaria Legislativa do Senado Federal

Situação: AGUARDANDO INCLUSÃO ORDEM DO DIA DE REQUERIMENTO

Ação: Aguardando inclusão em Ordem do Dia do Requerimento no 682, de 2015, do Senador Paulo Paim, que solicita audiência da $\mathrm{CDH}$.

15/06/2015 ATA-PLEN - SUBSECRETARIA DE ATA - PLENÁRIO

Situação: AGUARDANDO INCLUSÃO ORDEM DO DIA DE REQUERIMENTO

Ação: Encaminhado à publicação o Requerimento no 682, de 2015, de autoria do Senador Paulo Paim, que solicita, nos termos do art. 255, inciso II, alínea "c", item 12, do Regimento Interno do Senado Federal, que sobre o Projeto de Lei da Câmara no 26, de 2010, além da Comissão constantes do despacho inicial de distribuição, seja ouvida, também, a Comissão de Direitos Humanos e Legislação Participativa.

O Requerimento lido será incluído em Ordem do Dia, oportunamente.

Recebido em: $\quad$ 15/06/2015 às 17:17 por SLSF - Secretaria Legislativa do Senado Federal

15/06/2015 SSCLSF - SUBSEC. COORDENAÇÃO LEGISLATIVA DO SENADO

Ação: Encaminhado ao Plenário.

Recebido em: 15/06/2015 às 16:22 por ATA-PLEN - SUBSECRETARIA DE ATA - PLENÁRIO

08/06/2015 SSCLSF - SUBSEC. COORDENAÇÃO LEGISLATIVA DO SENADO

Situação: PRONTO PARA DELIBERAÇÃO DO PLENÁRIO

Ação: Incluído na Ordem do Dia da sessão deliberativa de 09.06.2015.

Discussão, em turno único.

$* * * * * * * * * * * * *$ Retificado em 08/06/2015*************

Ação lançada indevidamente.

Matéria aguardando inclusão em Ordem do Dia. 
26/11/2014 ATA-PLEN - SUBSECRETARIA DE ATA - PLENÁRIO

Situação: PRONTO PARA DELIBERAÇÃO DO PLENÁRIO

Ação: Encerrou-se em 25 de novembro o prazo para apresentação de emendas ao presente projeto. Não foram oferecidas emendas. A matéria será incluída em Ordem do Dia oportunamente.

26/11/2014 SSCLSF - SUBSEC. COORDENAÇÃO LEGISLATIVA DO SENADO

Ação: Encaminhado ao Plenário para comunicação do término do prazo para apresentação de emendas.

18/11/2014 SSCLSF - SUBSEC. COORDENAÇÃO LEGISLATIVA DO SENADO

Ação: Prazo para recebimento de emendas perante a Mesa: 19/11/2014 a 25/11/2014.

17/11/2014 ATA-PLEN - SUBSECRETARIA DE ATA - PLENÁRIO

Situação: AGUARDANDO RECEBIMENTO DE EMENDAS PERANTE A MESA

Ação: Encaminhado à publicação o Recurso no 10, de 2014, de autoria do Senador Aloysio Nunes Ferreira e outros Senadores, interposto no prazo regimental no sentido da apreciação da matéria pelo Plenário.

Abertura do prazo de cinco dias úteis para recebimento de emendas perante a Mesa, nos termos do art. 235, II, c, do Regimento Interno.

17/11/2014 SSCLSF - SUBSEC. COORDENAÇÃO LEGISLATIVA DO SENADO

Ação: Encaminhado ao Plenário para comunicação do término de prazo para interposição de recurso.

14/11/2014 SSCLSF - SUBSEC. COORDENAÇÃO LEGISLATIVA DO SENADO

Ação: Juntados quadro comparativo (fls. 38 e 39 ) e texto final revisado (fl. 40 ).

07/11/2014 SSCLSF - SUBSEC. COORDENAÇÃO LEGISLATIVA DO SENADO

Ação: Prazo para interposição de recurso: 10/11/2014 a 14/11/2014.

\section{7/11/2014 ATA-PLEN - SUBSECRETARIA DE ATA - PLENÁRIO}

Situação: AGUARDANDO INTERPOSIÇÃO DE RECURSO

Ação: Encaminhado à publicação o Parecer no 809, de 2014-CCJ, relator Senador Antônio Carlos Valadares, favorável, com a Emenda no 1-CCJ (Substitutiva).

Anunciado o recebimento do Ofício no 132/2014-CCJ, do Presidente da Comissão, comunicando a aprovação, em turno suplementar, de Substitutivo à presente matéria.

Abertura do prazo de cinco dias úteis para interposição de recurso, por um décimo da composição da Casa, para que a matéria seja apreciada pelo Plenário. (Art. 91, §§ 3ㅇa 5으, RISF) 
05/11/2014 SSCLSF - SUBSEC. COORDENAÇÃO LEGISLATIVA DO SENADO

Situação: AGUARDANDO LEITURA PARECER (ES)

Ação: Aguardando leitura de parecer da CCJ.

Juntada, às fls. 33-36, legislação citada no parecer.

05/11/2014 CCJ - Comissão de Constituição, Justiça e Cidadania

Ação: À SSCLSF, para prosseguimento da tramitação.

\footnotetext{
05/11/2014 CCJ - Comissão de Constituição, Justiça e Cidadania

Situação: APRECIADA EM DECISÃO TERMINATIVA PELAS COMISSÕES

Ação: Na 43a Reunião Ordinária, realizada nesta data, a Comissão adota definitivamente o Substitutivo oferecido ao PLC n 26, de 2010, em Turno Suplementar, nos termos do art. 284 do RISF, relatado pelo Senador Antonio Carlos Valadares.

Anexei o Texto Final do Substitutivo ao PLC n²6, de 2010, na CCJ.

Anexei o Ofício n 132/2014-PRESIDÊNCIA/CCJ, que comunica a decisão da Comissão em caráter terminativo, no Turno Suplementar, para ciência do Plenário e publicação no Diário do Senado Federal (art. 91 e 92 do RISF).
}

\section{0/10/2014 CCJ - Comissão de Constituição, Justiça e Cidadania \\ Situação: AGUARDANDO TURNO SUPLEMENTAR EM APRECIAÇÃO TERMINATIVA \\ Ação: Recebido na CCJ às 8 horas e 26 minutos.}

Matéria incluída na Pauta da Comissão para apreciação em Turno Suplementar.

\section{9/10/2014 ATA-PLEN - SUBSECRETARIA DE ATA - PLENÁRIO}

Situação: AGUARDANDO RECEBIMENTO DE EMENDAS

Ação: Anunciado o recebimento do Ofício no 127, de 2014, do Presidente da Comissão de Constituição, Justiça e Cidadania, que comunica a aprovação, em caráter terminativo, de Substitutivo ao presente projeto.

Poderão ser oferecidas emendas ao Substitutivo, até o encerramento da discussão, em turno suplementar, perante a Comissão de Constituição, Justiça e Cidadania.

\section{9/10/2014 SSCLSF - SUBSEC. COORDENAÇÃO LEGISLATIVA DO SENADO}

Ação: Recebido neste Órgão, às $19 h 50$.

Encaminhado ao Plenário.

29/10/2014 CCJ - Comissão de Constituição, Justiça e Cidadania

Ação: À SSCLSF, para prosseguimento da tramitação.

\section{9/10/2014 CCJ - Comissão de Constituição, Justiça e Cidadania}

Situação: AGUARDANDO TURNO SUPLEMENTAR EM APRECIAÇÃO TERMINATIVA

Ação: Na 42a Reunião Ordinária, realizada nesta data, a Comissão aprova o Substitutivo oferecido ao PLC no 26, de 2010, relatado pelo 
Senador Antonio Carlos Valadares.

O Substitutivo será submetido a Turno Suplementar, nos termos do disposto no art. 282 c/c art. 92 do RISF.

Anexei o Ofício no 127/2014- PRESIDÊNCIA/CCJ, que comunica a decisão da Comissão e a inclusão na Pauta da próxima Reunião, para apreciação em Turno Suplementar.

24/10/2014 CCJ - Comissão de Constituição, Justiça e Cidadania

Situação: INCLUÍDA NA PAUTA DA REUNIÃO

Ação: Matéria incluída na Pauta da Comissão.

01/08/2014 CCJ - Comissão de Constituição, Justiça e Cidadania

Ação: A partir de 1ㅇ de agosto de 2014 os boletins de ação legislativa não mais serão impressos, nos termos da Instrução Normativa no 1, de 2014, do Secretário-Geral da Mesa. As consultas sobre a tramitação da matéria devem ser realizadas diretamente no sistema eletrônico próprio.

19/03/2014 CCJ - Comissão de Constituição, Justiça e Cidadania

Situação: INCLUÍDA NA PAUTA DA REUNIÃO

Ação: Na 8a Reunião Ordinária, realizada nesta data, é lido o Relatório pelo Senador Antonio Carlos Valadares, ficando adiada a discussão.

25/02/2014 CCJ - Comissão de Constituição, Justiça e Cidadania

Situação: INCLUÍDA NA PAUTA DA REUNIÃO

Ação: Recebido às 17h45 Relatório reformulado pelo Senador Antonio Carlos Valadares, com voto pela aprovação do projeto, nos termos de emenda substitutiva que apresenta.

Matéria incluída na Pauta da Comissão.

14/02/2014 CCJ - Comissão de Constituição, Justiça e Cidadania

Situação: INCLUÍDA NA PAUTA DA REUNIÃO

Ação: Matéria incluída na Pauta da Comissão.

19/12/2013 CCJ - Comissão de Constituição, Justiça e Cidadania

Situação: PRONTA PARA A PAUTA NA COMISSÃO

Ação: Recebido às $15 \mathrm{~h} 20$ relatório do Senador Antonio Carlos Valadares, com voto pela aprovação do Projeto, com duas emendas que apresenta.

Matéria pronta para a Pauta na Comissão.

31/10/2013 CCJ - Comissão de Constituição, Justiça e Cidadania

Situação: MATÉRIA COM A RELATORIA

Ação: Distribuído ao Senador Antonio Carlos Valadares, para emitir relatório. 


\title{
TRAMITAÇÃO
}

14/01/2011 CCJ - Comissão de Constituição, Justiça e Cidadania

Situação: AGUARDANDO DESIGNAÇÃO DO RELATOR

Ação: Recebido na Comissão nesta data.

Matéria aguardando designação de Relator.

\section{3/01/2011 SSCLSF - SUBSEC. COORDENAÇÃO LEGISLATIVA DO SENADO}

Ação: A presente proposição continua a tramitar,nos termos dos incisos do art. 332 do Regimento Interno e do Ato no 4, de 2010 , da Mesa do Senado Federal.

A matéria volta à CCJ.

22/12/2010 CCJ - Comissão de Constituição, Justiça e Cidadania

Ação: À SCLSF, em cumprimento ao disposto no art. 332 do Regimento Interno do Senado Federal (Final da 53ạ Legislatura).

\footnotetext{
15/12/2010 CCJ - Comissão de Constituição, Justiça e Cidadania

Situação: PRONTA PARA A PAUTA NA COMISSÃO

Ação: Na 54a Reunião Ordinária realizada nesta data, a matéria é retirada de Pauta.
}

\author{
08/11/2010 CCJ - Comissão de Constituição, Justiça e Cidadania \\ Situação: INCLUÍDA NA PAUTA DA REUNIÃO \\ Ação: Matéria incluída na Pauta da Comissão.
}

\footnotetext{
31/05/2010 CCJ - Comissão de Constituição, Justiça e Cidadania

Situação: PRONTA PARA A PAUTA NA COMISSÃO

Ação: Recebido o Relatório da Senadora Lúcia Vânia, com voto pela aprovação do Projeto.

Matéria pronta para a Pauta na Comissão.
}

\footnotetext{
28/04/2010 CCJ - Comissão de Constituição, Justiça e Cidadania

Situação: MATÉRIA COM A RELATORIA

Ação: Distribuído à Senadora Lúcia Vânia, para emitir relatório.
}

23/04/2010 CCJ - Comissão de Constituição, Justiça e Cidadania

Situação: AGUARDANDO DESIGNAÇÃO DO RELATOR

Ação: Não foram oferecidas emendas no prazo regimental.

Matéria aguardando distribuição.

15/04/2010 CCJ - Comissão de Constituição, Justiça e Cidadania 
PROJETO DE LEI DA CÂMARA n 26, de 2010

\begin{tabular}{|c|c|c|c|c|}
\hline Data & Tipo & Comissão & Ação legislativa & Observação \\
\hline $19 / 12 / 2013$ & Relatório & $\begin{array}{l}\text { Comissão de Constituição, } \\
\text { Justiça e Cidadania }\end{array}$ & $\begin{array}{l}\text { Recebido às } 15 \mathrm{~h} 20 \text { relatório do Senador Antonio Carlos Valadares, com } \\
\text { voto pela aprovação do Projeto, com duas emendas que apresenta. } \\
\text { Matéria pronta para a Pauta na Comissão. }\end{array}$ & \\
\hline $25 / 02 / 2014$ & Relatório & $\begin{array}{l}\text { Comissão de Constituição, } \\
\text { Justiça e Cidadania }\end{array}$ & $\begin{array}{l}\text { Recebido às } 17 \text { h45 Relatório reformulado pelo Senador Antonio Carlos } \\
\text { Valadares, com voto pela aprovação do projeto, nos termos de emenda } \\
\text { substitutiva que apresenta. } \\
\text { Matéria incluída na Pauta da Comissão. }\end{array}$ & \\
\hline $29 / 10 / 2014$ & $\begin{array}{l}\text { Parecer aprovado } \\
\text { na comissão }\end{array}$ & $\begin{array}{l}\text { Comissão de Constituição, } \\
\text { Justiça e Cidadania }\end{array}$ & $\begin{array}{l}\text { Na 42a Reunião Ordinária, realizada nesta data, a Comissão aprova o } \\
\text { Substitutivo oferecido ao PLC no 26, de 2010, relatado pelo Senador } \\
\text { Antonio Carlos Valadares. } \\
\text { O Substitutivo será submetido a Turno Suplementar, nos termos do } \\
\text { disposto no art. } 282 \text { c/c art. } 92 \text { do RISF. } \\
\begin{array}{l}\text { Anexei o Ofício no } 127 / 2014-\text { PRESIDÊNCIA/CCJ, que comunica a decisão da } \\
\text { Comissão e a inclusão na Pauta da próxima Reunião, para apreciação em } \\
\text { Turno Suplementar. }\end{array}\end{array}$ & \\
\hline $07 / 11 / 2014$ & $\begin{array}{l}\text { Avulso do } \\
\text { ParecerP.S809/201 }\end{array}$ & $\begin{array}{l}\text { SUBSECRETARIA DE ATA - } \\
\text { PLENÁRIO }\end{array}$ & $\begin{array}{l}\text { Encaminhado à publicação o Parecer no 809, de 2014-CCJ, relator Senador } \\
\text { Antônio Carlos Valadares, favorável, com a Emenda no 1-CCJ (Substitutiva). } \\
\text { Anunciado o recebimento do Ofício no } 132 / 2014-C C J \text {, do Presidente da } \\
\text { Comissão, comunicando a aprovação, em turno suplementar, de } \\
\text { Substitutivo à presente matéria. } \\
\text { Abertura do prazo de cinco dias úteis para interposição de recurso, por um } \\
\text { décimo da composição da Casa, para que a matéria seja apreciada pelo } \\
\text { Plenário. (Art. 91, §§ 30 a 5o, RISF) }\end{array}$ & \\
\hline $14 / 11 / 2014$ & $\begin{array}{l}\text { Quadro } \\
\text { comparativo }\end{array}$ & $\begin{array}{l}\text { SUBSEC. COORDENAÇÃO } \\
\text { LEGISLATIVA DO SENADO }\end{array}$ & Juntados quadro comparativo (fls. 38 e 39 ) e texto final revisado (fl. 40). & $\begin{array}{l}\text { Lei no 9.503/1997 x PLC x } \\
\text { Emenda no 1- CCJ } \\
\text { (Substitutivo) }\end{array}$ \\
\hline $17 / 11 / 2014$ & $\begin{array}{l}\text { Avulso de } \\
\text { recursoR.S10/2014 }\end{array}$ & $\begin{array}{l}\text { SUBSECRETARIA DE ATA - } \\
\text { PLENÁRIO }\end{array}$ & $\begin{array}{l}\text { Encaminhado à publicação o Recurso no } 10 \text {, de 2014, de autoria do Senador } \\
\text { Aloysio Nunes Ferreira e outros Senadores, interposto no prazo regimental } \\
\text { no sentido da apreciação da matéria pelo Plenário. } \\
\text { Abertura do prazo de cinco dias úteis para recebimento de emendas } \\
\text { perante a Mesa, nos termos do art. } 235 \text {, II, c, do Regimento Interno. }\end{array}$ & \\
\hline
\end{tabular}

